Florida International University FIU Digital Commons

$7-7-2000$

\title{
Ammonite biostratigraphy, lithofacies variations, and paleoceanographic implications for barremian- aptian sequences of northeastern Mexico
}

Ricardo Barragan

Florida International University

DOI: $10.25148 /$ etd.FI14050434

Follow this and additional works at: https://digitalcommons.fiu.edu/etd

Part of the Geology Commons

\section{Recommended Citation}

Barragan, Ricardo, "Ammonite biostratigraphy, lithofacies variations, and paleoceanographic implications for barremian-aptian sequences of northeastern Mexico" (2000). FIU Electronic Theses and Dissertations. 1402.

https://digitalcommons.fiu.edu/etd/1402 
FLORIDA INTERNATIONAL UNIVERSITY

Miami, Florida

\begin{abstract}
AMMONITE BIOSTRATIGRAPHY, LITHOFACIES VARIATIONS, AND PALEOCEANOGRAPHIC IMPLICATIONS FOR BARREMIAN-APTIAN SEQUENCES OF NORTHEASTERN MEXICO
\end{abstract}

A dissertation submitted in partial fulfillment of the requirements for the degree of DOCTOR OF PHILOSOPHY in GEOLOGY

by

Ricardo Barragan 
To: Dean Arthur W. Herriott

College of Arts and Sciences

This dissertation, written by Ricardo Barragan, and entitled Ammonite Biostratigraphy, Lithofacies Variations, and Paleoceanographic implications for Barremian-Aptian Sequences of Northeastern Mexico, having been approved in respect to style and intellectual content, is referred to you for judgment.

We have read this dissertation and recommend that it be approved
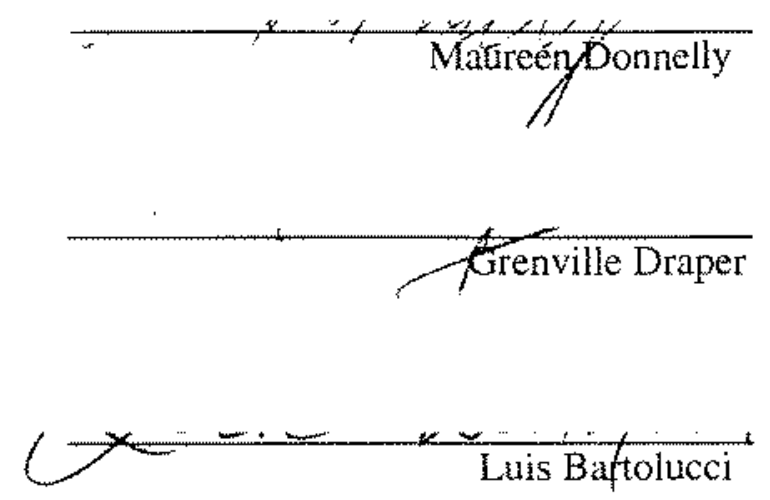

Date of Defense: July 7,2000

The dissertation of Ricardo Barragan is approved.

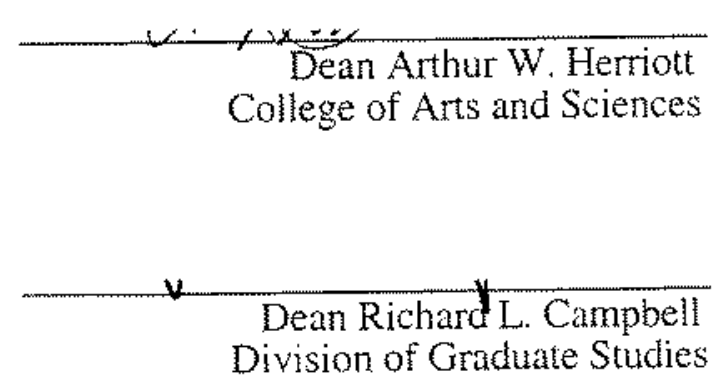

Florida International University, 2000 
(C) Copyright 2000 by Ricardo Barragan All rights reserved. 


\section{DEDICATION}

This dissertation is dedicated to my family. Special appreciation is given to my parents, Margarita and Justo. Their support, encouragement, and inspiration were fundamental in the completion of this work. 


\section{ACKNOWLEDGMENTS}

I wish to thank my advisor and major professor, Dr. Florentin Maurrasse for his continuous encouragement and wise counseling in the completion of this research. I would also like to express my gratitude to the other three members of my dissertation committee, Dr. Matren Donelly, Dr. Grenville Draper, and Dr. Luis Bartolucci for their insightful scientific and editorial comments that served to improve this dissertation.

I am specially grateful to Dr. Celestina Gonzalez Arreola, who suggested the topic for my dissertation and who was an important supporter during difficult times throughout the completion of this research.

Special appreciation is given to the "Dirección General de Asuntos del Personal Académico" and the "Instituto de Geologia" of the Autonomous National University of Mexico, which provided me with a full scholarship throughout my doctoral studies, and helped me with the financial support for the field research campaigns respectively.

Special thanks go to my cousins Alejandro and Gilberto Nieto. The countless hours that they spent with me in the arduous field work are worthy to mention.

I am sincerely grateful to Diane Pirie and Lois Geier from the FIU Geology Department. Their tremendous help in providing me with all the necessary materials for the completion of this research is truly appreciated.

I wish to give a special mention to Dr. Laurel Collins. Her comments about some of the paleoecological aspects of this research are gratefully acknowledged.

Finally, I want to thank my friends Alfredo Cordova Martinez, Liliana Lara Morales, and Jose Alberto Alarcon Diaz. Their support and understanding were crucial for the completion of this work.

To all of them, Thanks! 


\title{
ABSTRACT OF THE DISSERTATION
}

\section{AMMONITE BIOSTRATIGRAPHY, LITHOFACIES VARIATIONS, AND PALEOCEANOGRAPHIC IMPLICATIONS FOR BARREMIAN-APTIAN SEQUENCES OF NORTHEASTERN MEXICO}

by

\author{
Ricardo Barragan \\ Florida International University, 2000 \\ Miami, Florida \\ Professor Florentin Maurrasse, Major Professor
}

Two Barremian-Aptian sequences studied in Durango and Nuevo Leon States, northeastem Mexico include three lithic units which have been described as the Cupido Formation of Barremian-early Early Aptian age, its tateral equivalent, the Lower Tamaulipas Formation, and the La Peña Formation extending through the early Albian.

The present work improves the existing ammonite Aptian biozonation by considering constraints associated with a discontinuous spatial and temporal record of the different taxa within the La Peña Formation.

Four ammonite biozones are established: 1) The Dufrenoyia justinae Zone for the late Early Aptian, 2) The Burckhardtites nazasensis/Rhytidoplites robertsi Zone for the middle Aptian, 3) The Cheloniceras inconstans Zone for the early Late Aptian, and 4) The Hypacanthoplites cf. leanzae Zone for the late late Aptian.

Also, a detailed sedimentological analysis of the sections shed further light on the possible causes that controlled intermittent occurrences of the ammonites in relation to the prevaling paleoceanographic and paleoecologic conditions in northeastern Mexico during the late Barremian-Aptian. 
Microfacies analyses show that the upper part of the Cupido facies are represented by biocalcirudite with rudists, biocalcarenites with oolites and algae, and rich benthonic foraminifera assemblages with ostracods. These facies are related to paleoceanographic conditions of sedimentation within a shallow marine carbonate platform. Its lateral equivalent, deep-water facies extended to the southeast and it is represented by the Lower Tamaulipas Formation, which includes planktonic foraminifera, ostracods, and mollusk and echinoid fragments. The beginning of deposition of the La Peña Formation in the late Early Aptian is characterized by an increase in terrigenous materials and significant decrease in the abundance of benthic fauna. The La Peña Formation is recognized by an alternation of marls and shale limestones containing ammonites, planktonic foraminifera, ostracods, and radiolaria toward the top. Accumulation of the La Peña continued throughout the end of the Aptian and records changes in conditions of sedimentation and productivity in the water column, which abruptly terminated the carbonate deposition in the Cupido Platform.

Results of carbon/carbonate content analyses show that changes from the Cupido to the La Peña facies are also characterized by an increase of organic carbon, which indicate the onset of enhanced dysoxic/anoxic conditions in the lower water column. 


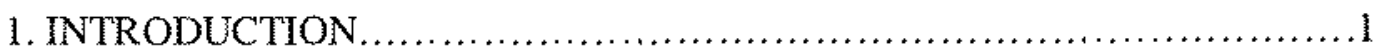

2. GEOGRAPHIC AND GEOLOGIC SETTING $\ldots \ldots \ldots \ldots \ldots \ldots \ldots \ldots \ldots \ldots 7$

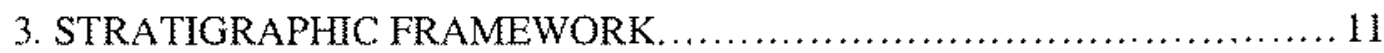

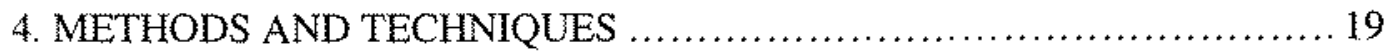

Field Work..................................................... 19

Laboratory Analyses......................................... 20

Microfacies Analysis ................................................ 20

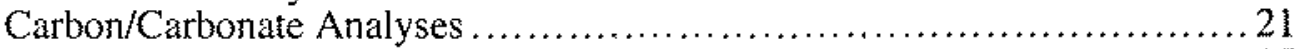

Ammonite Biostratigraphy ........................................... 25

Ammonite Biochronology ......................................... 25

5. LITHOSTRATIGRAPHY ...................................................

6. CARBON/CARBONATE ANALYSES ...................................42

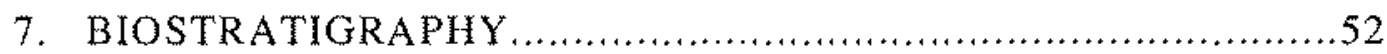

8. SYSTEMATIC AMMONITE PALEONTOLOGY ............................60

Order Nautiloidea .................................................66

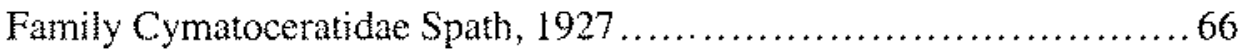

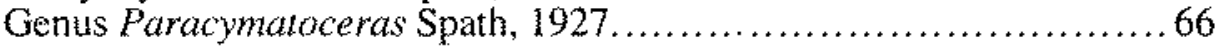

Paracymatoceras milleri Humphrey, 1949 ......................66 66

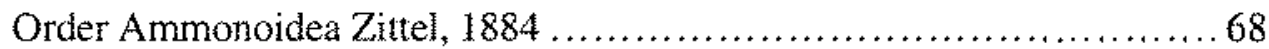

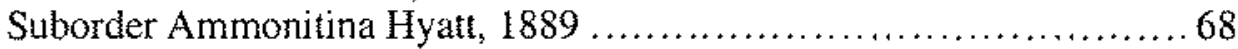

Superfamily Desmocerataceae Zittel, $1895 \ldots \ldots \ldots \ldots \ldots \ldots \ldots \ldots \ldots . \ldots 6$

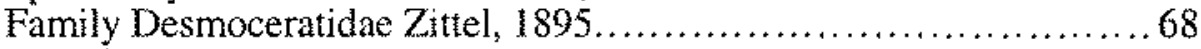

Subfamily Puzosinae Spath, $1922 \ldots \ldots \ldots \ldots \ldots \ldots \ldots \ldots \ldots \ldots \ldots 6 . \ldots \ldots$

Genus Pseudohaploceras Hyatt, $1900 \ldots \ldots \ldots \ldots \ldots \ldots \ldots \ldots \ldots . \ldots 6$

Pseudohaploceras aguilerae (Burckhardt, 1925) ................69

Pseudohaploceras jacobi (Burckhardt, 1925) .................71

Pseudohaploceras reesidei (Humphrey, 1949) .................. 75

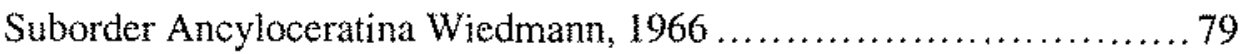

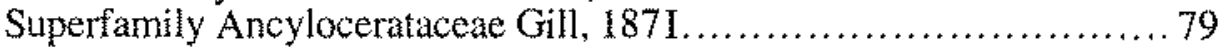

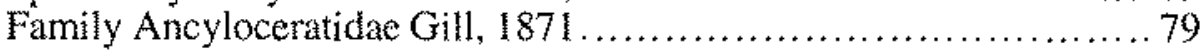

Subfamily Ancyloceratinae Gill, $1871 \ldots \ldots \ldots \ldots \ldots \ldots \ldots \ldots \ldots \ldots$

Genus Peltocrioceras Spath, 1924 ................................. 79

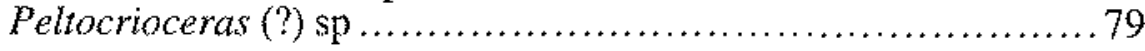


Subfamily Helicancylinae Hyatt, $1894 \ldots \ldots \ldots \ldots \ldots \ldots \ldots \ldots \ldots 1$

Genus Acrioceras Hyatt, $1900 \ldots \ldots \ldots \ldots \ldots \ldots \ldots \ldots \ldots \ldots \ldots . \ldots 1$

Subgenus Acrioceras (Epacrioceras) Egoian, $1974 \ldots \ldots \ldots \ldots \ldots 82$

Acrioceras (Epacrioceras) (?) sp.......................... 82

Superfamily Douvilleicerataceae Parona \& Bonarelli, $1897 \ldots \ldots \ldots \ldots 83$

Family Douvilleiceratidae Parona \& Bonarelli, $1897 \ldots \ldots \ldots \ldots \ldots \ldots 83$

Subfamily Cheloniceratinae Spath, $1923 \ldots \ldots \ldots \ldots \ldots \ldots \ldots \ldots . \ldots 3$

Genus Cheloniceras Hyatt, $1903 \ldots \ldots \ldots \ldots \ldots \ldots \ldots \ldots \ldots \ldots . . . \ldots 3$

Cheloniceras fossae Humphrey, 1949 ....................... 84

Cheloniceras inconstans Humphrey, 1949 ................... 87

Superfamily Deshayesitaceae Stoyanow, $1949 \ldots \ldots \ldots \ldots \ldots \ldots \ldots . \ldots . \ldots 1 . \ldots$

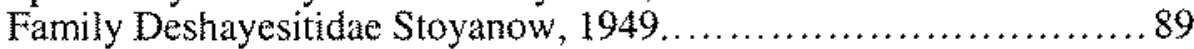

Subfamily Deshayesitinae Stoyanow, $1949 \ldots \ldots \ldots \ldots \ldots \ldots \ldots \ldots . \ldots . \ldots 19$

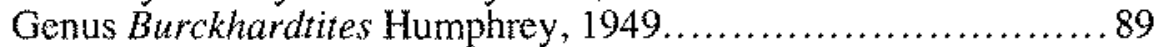

Burckhardtites nazasensis (Burckhardt, 1925) ................ 89

Genus Dufrenoyia Kilian and Reboul, $1915 \ldots \ldots \ldots \ldots \ldots \ldots \ldots 92$

Dufrenoyia bösei Humphrey, $1949 \ldots \ldots \ldots \ldots \ldots \ldots \ldots \ldots \ldots . \ldots . \ldots . \ldots 2$

Dufrenoyia dufrenoyi (Orbigny, 1840) .......................95

Dufrenoyia durangentsis Humphrey, $1949 \ldots \ldots \ldots \ldots \ldots \ldots . . . . . . .100$

Dufrenoyia justinae (Hill, 1893) ....................... 102

Dufrenoyia scotti Humphrey, 1949....................... 107

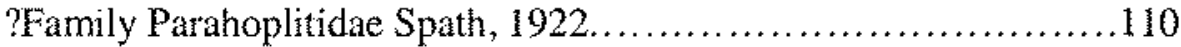

Subfamily Acanthohoplitinae Stoyanow, $1949 \ldots \ldots \ldots \ldots \ldots \ldots \ldots 10$

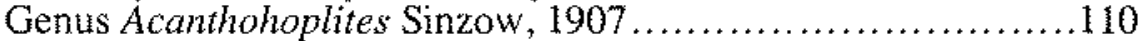

Acanthohoplites acutecosta Riedel, 1938 ....................110

Acanthohoplites aschiltaensis (Anthula, 1899)...............112

Acanthohoplites potreritensis Humphrey, 1949) ............115

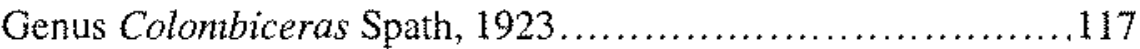

Colombiceras spathi Humphrey, $1949 \ldots \ldots \ldots \ldots \ldots \ldots \ldots \ldots \ldots 17$

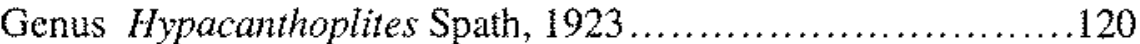

Hypacanthoplites cf. leanzae, Humphrey, 1949 ..............120

Genus Penaceras Cantu, 1963 .............................122

Penaceras rursiradiatus (Humphrey, 1949)...................122

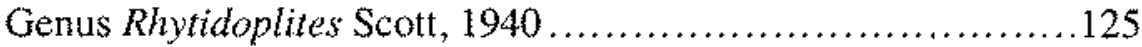

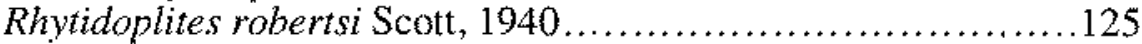

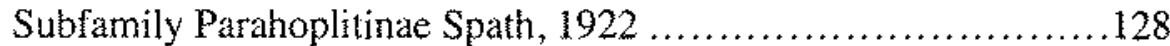

Genus Kazanskyella Stoyanow, 1949 ........................128

cf. Kazanskyella arizonica Stoyanow, $1949 \ldots \ldots \ldots \ldots \ldots \ldots \ldots . \ldots \ldots$

Genus Parahoplites Anthula, 1900 ..........................130

Parahoplites mexicanus Humphrey, 1949 ....................130 
9. DISCUSSION

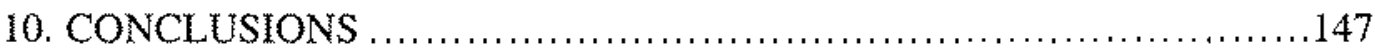

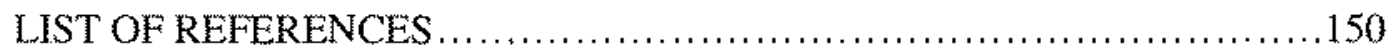

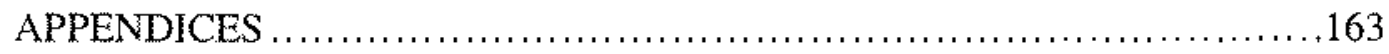

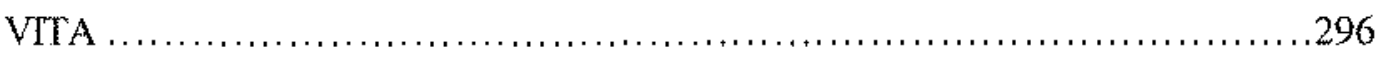




\section{LIST OF FIGURES}

FIGURE

PAGE

1. Paleogeography of Neocomian-lower Aptian of northern and northeastern Mexico (After Gonzalez-Garcia, 1976, in Moran-Zenteno, 1994). Dashed lines indicate limits of states, as shown in Figure 2. Platform limestone indicates extension of the Cupido Formation, whereas Basinal limestone indicates extension of its lateral equivalent Lower Tamaulipas Formation

2. Map of Mexico showing the region referred to as northeastern Mexico, including the location of the stratigraphic sections used in this study. States: 1) $\mathrm{CH}=$ Chihuahua, 2) $\mathrm{COA}=$ Coahuila, 3) $\mathrm{DUR}=$ Durango, 4) ZAC=Zacatecas, 5) NL=Nuevo Leon, 6) TAM=Tamaulipas,

7) $\mathrm{SLP}=\mathrm{San}$ Luis Potosi

3. Physiographic regions of Mexico. 1) Baja California Peninsula,

II) Sonoran Desert, III) Sierra Madre Occidental, IV) Sierras and Plains of the North, V) Sierra Madre Oriental, VI) Great Plain of North America, VII) Pacific Coastal Plain, VIII) Coastal Plain of Northern Gulf of Mexico, IX) Central Mesa, X) Neovolcanic Axis, XI) Yucatan Peninsula, XII) Sierra Madre del Sur, XIII) Southern Gulf Coastal Plain, XIV) Chiapas Mountains, XV) Central American Cordillera (After Moran-Zenteno, 1994).

4. Chronolithostratigraphic correlation of the two stratigraphic sections studied in the present work placed within the stratigraphic framework of northeastern Mexico.

5. Stratigraphic column displaying thicknesses and physical characteristics of individual strata throughout the stratigraphic sequence

at Presa Francisco Zarco, Durango.

6. Stratigraphic column displaying thicknesses and physical characteristics of individual strata throughout the stratigraphic sequence at La Boca Canyon, Nuevo Leon....

7. Stratigraphic columns displaying the distribution of microfacies types along the two stratigraphic sequences of this study.

LTF=Lower Tamaulipas Formation.

8. Plot showing the temporal succession of the relative abundance of benthic foraminifera, planktonic foraminifera, and radiolaria, throughout the stratigraphic sequence at Francisco Zarco section.

9-a. Stratigraphic column of the Presa Francisco Zarco section, displaying the vertical variations on the Carbon/Carbonate content (first part). 
9-b. Stratigraphic column of the Presa Francisco Zarco section, displaying the vertical variations on the Carbon/Carbonate content (second part)......

9-c. Stratigraphic column of the Presa Francisco Zarco section, displaying the vertical variations on the Carbon/Carbonate content (third part)....

10-a. Stratigraphic column of the La Boca Canyon section, displaying the vertical variations on the Carbon/Carbonate content (first part).....

10-b. Stratigraphic column of the La Boca Canyon section, displaying the vertical variations on the Carbon/Carbonate content (second part).....

10-c. Stratigraphic column of the La Boca Canyon section, displaying the vertical variations on the Carbon/Carbonate content (third part).....

11. Stratigraphic distribution of ammonite species within the La Peña Formation at Francisco Zarco section and proposed ammonite biozonation for such formation. in pocket

12. Sketch of the three main sections of an ammonoid shell. Orientation is shown as in living position, which is assumed to be analog with modern living Natilus....

13. Sketch of an ammonite showing the morphological features used in the description of the shells, including the measurable parameters shown with asterisks. Orientation of shell is not in living position 


\section{LIST OF PLATES}

PLATE

PAGE

1. Microfacies subunit PFZ-A, Cupido Formation, Presa Francisco Zarco ..............166

2. Microfacies subunit PFZ-A, Cupido Formation, Presa Francisco Zarco...............168

3. Microfacies subunits PFZ-A and PFZ-B, Cupido Formation, Presa Francisco Zarco.

4. Microfacies subunit PFZ-B, Cupido Formation, Presa Francisco Zarco.

5. Microfacies subunit PFZ-C, Cupido Formation, Presa Francisco Zarco

6. Microfacies subunit PFZ-C, Cupido Formation, Presa Francisco Zarco. 176

7. Microfacies subunit PFZ-D, sample PFZ-46 b, Cupido Formation, Presa Francisco Zarco

8. Microfacies subunit PFZ-D, Sample PFZ-46 c, Cupido Formation,

Presa Francisco Zarco

9. Microfacies subunit PFZ-D, upper part, Cupido Formation,

Presa Francisco Zarco.....

10. Microfacies subunit PFZ-D, upper part, sample PFZ-48, Cupido Formation, Presa Francisco Zarco.....

11. Microfacies subunit PFZ-D, upper part,

Cupido Formation, Presa Francisco Zarco. 186

12. Microfacies subunit PFZ-E, Cupido Formation, Presa Francisco Zarco. 188

13. Microfacies subunits PFZ-F and PFZ-G, Cupido Formation, Presa Francisco Zarco....

14. Microfacies subunit PFZ-G, Cupido Formation, Presa Francisco Zarco.

15. Microfacies subunit PFZ-G, Cupido Formation, Presa Francisco Zarco.

16. Microfacies subunit PFZ-G, sample PFZ-58 c:

Cupido Formation, Presa Francisco Zarco.

17. Microfacies subunit PFZ-G, Cupido Formation, Presa Francisco Zarco 198

18. Microfacies subunit PFZ-G, sample PFZ-59 d, Cupido Formation, Presa Francisco Zarco. .200

19. Microfacies subunit PFZ-G, sample PFZ-59 d, Cupido Formation, Presa Francisco Zarco. 202 
20. Microfacies subunit PFZ G, sample PFZ-59 e,

Cupido Formation, Presa Francisco Zarco.

21. Microfacies subunit PFZ-G, sample PFZ-59 e, Cupido Formation, Presa Francisco Zarco.

22. Microfacies subunit PFZ-G, sample PFZ-59 e, Cupido Formation, Presa Francisco Zarco ............................................208

23. Microfacies subunit PFZ-H, La Peña Formation, Presa Francisco Zarco............210

24. Microfacies subunit PFZ-H, La Peña Formation, Presa Francisco Zarco ............212

25. Microfacies subunit PFZ-I, La Peña Formation, Presa Francisco Zarco ..............214

26. Microfacies subunit PFZ-I, La Peña Formation, Presa Francisco Zarco ...............216

27. Microfacies subunit PFZ-1, La Peña Formation, Presa Francisco Zarco ..............218

28. Microfacies subunit PFZ-I, La Peña Formation, Presa Francisco Zarco.............220

29. Microfacies subunit PFZ-I, La Peña Formation, Presa Francisco Zarco..............222

30. Microfacies subunit PFZ I, La Peña Formation, Presa Francisco Zarco ..............222

31. Microfacies subunit PFZ1, La Peña Formation, Presa Francisco Zarco .............226

32. Microfacies subunit PFZ J, La Peña Formation, Presa Francisco Zarco...............228

33. Microfacies subunit PFZ J, La Peña Formation, Presa Francisco Zarco..............230

34. Microfacies subunit PFZ-J, La Peña Formation, Presa Francisco Zarco...............2232

35. Microfacies subunit PFZ-K, La Peña Formation, Presa Francisco Zarco ..............234

36. Microfacies subunit PFZ-K, La Peña Formation, Presa Francisco Zarco ..............236

37. Microfacies of the Lower Tamaulipas Formation, La Boca Canyon..................238

38. Microfacies of the Lower Tamaulipas Formation, La Boca Canyon..................240

39. Microfacies of the Lower Tamaulipas Formation, La Boca Canyon ...................242

40. Microfacies of the La Peña Formation, La Boca Canyon................................244

41. Microfacies of the La Peña Formation, La Boca Canyon...........................246

42. Microfacies of the La Peña Formation, La Boca Canyon..............................248

43. Microfacies of the La Peña Formation, La Boca Canyon..............................250

44. Microfacies of the La Peña Formation, La Boca Canyon.............................252 
45. Microfacies of the La Peña Formation, La Boca Canyon...............................254

46. Microfacies of the La Peña Formation, La Boca Canyon..............................256

47. Nautiloidea. La Peña Formation. Presa Francisco Zarco section.

Paracymatoceras milleri Humphrey..............................................265

48. Nautiloidea. La Peña Formation. Presa Francisco Zarco section.

Paracymatoceras milleri Humphrey.

49. Ammonites of the La Peña Formation. Presa Francisco Zarco section.

Pseudohaploceras aguilerae (Burckhardt).

Pseudohaploceras jacobi (Burckhardt)....

50. Ammonites of the La Peña Formation. Presa Francisco Zarco and La Boca Canyon sections.

Pseudohaploceras reesidei (Humphrey).

51. Ammonites of the La Peña Formation. Presa Francisco Zarco section.

Peltocrioceras (?) sp.

Cheloniceras fossae Humphrey.

Cheloniceras inconstans Humphrey.

Burckhardtites nazasensis (Burckhardt)

52. Ammonites of the La Peña Formation. Presa Francisco Zarco section.

Dufrenoyia bösei Humphrey.

Dufrenoyia dufrenoyi (Orbigny)....

53. Ammonites of the La Peña Formation. Presa Francisco Zarco section.

Dufrenoyia dufrenoyi (Orbigny).

Dufrenoyia durangensis Humphrey.

Dufrenoyia justinae (Hill).

54. Ammonites of the La Peña Formation. Presa Francisco Zarco section.

Dufrenoyia justinae (Hill).

55. Ammonites of the La Peña Formation. Presa Francisco Zarco and La Boca Canyon sections.

Dufrenoyia justinae (Hill).

56. Ammonites of the La Peña Formation. Presa Francisco Zarco

and La Boca Canyon sections.

Dufrenoyia scotti Humphrey.

Acanthohoplites acutecosta Riedel.

Acantholoplites aschiltaensis (Anthula).

57. Ammonites of the La Peña Formation. Presa Francisco Zarco

and La Boca Canyon sections.

Acantholoplites potreritensis Humphrey.

Colombiceras spathi Humphrey.

Hypacanthoplites of. leanzae Humphrey.... 
58. Ammonites of the La Peña Formation. Presa Francisco Zarco and La Boca Canyon sections.

Penaceras nursiradiatus (Hill).

Rhytidoplites robertsi Scott.

cf. Kazanskyella arizonica Stoyanow.....

59. Ammonites of the La Peña Formation. Presa Francisco Zarco and La Boca Canyon sections.

Parahoplites mexicanus Humphrey 


\section{CHAPTER 1. INTRODUCTION}

Ammonoids are extinct mollusks of the Class Cephalopoda, which appeared in the Early Devonian and became extinct at the end of the Cretaceous (Arkell et al., 1957). Our knowledge of this group is mostly based on integrated stratigraphic analyses and taxonomic and paleoecological studies of their preserved hard parts, which consist of the external shells and the opercula. The great abundance of ammonites in Mesozoic rocks, their worldwide distribution and wide variety of forms, make of this fossil group a good tool for biostratigraphic analyses and for the establishment of biozonal schemes and correlation on the basis of their stratigraphic occurrences. In fact, the biostratigraphic studies of index species of this group, provided the fundamental framework for the chronostratigraphic divisions of the Cretaceous (d'Orbigny, 1840; Stoyanow, 1949; Casey, 1961; Fabre-Taxy, et al., 1965; Kemper, 1970).

The Lower Cretaceous series of northeastem Mexico is very rich in ammonites fauna, making this region an ideal area for ammonite paleontological studies, and for the establishment of their biozonal schemes. In this work, a rich assemblage of ammonite species from the Aptian of northeastern Mexico is analyzed in terms of its biostratigraphic values and paleoecological implications.

\section{PREVIOUS STUDIES}

The first stratigraphic studies of the Lower Cretaceous series of northern Mexico began early in the twentieth century with the work of Burckhardt $(1906,1912,1925,1930)$. These early publications not only provided important information for lithologic and biostratigraphic correlation in the area, but they were the first contributions to the understanding of the paleogeography of northern Mexico. Böse (1923) undertook the first comprehensive geological study of the region, and established the concept of a Late 
Jurassic-Early Cretaceous land-mass in the State of Coahuila. Böse's work was complemented by further investigation (Böse and Cavins, 1927), on the Cretaceous and Tertiary series of southem Texas and northern Mexico. These authors reported the presence of Aptian ammonite assemblages from the State of Coahuila. Imlay (1936) defined a very distinctive lithostratigraphic unit, which he named the La Peña Formation, chatacteristic of the Aptian of northern Mexico. Muir (1936), studied the geology of the Tampico region within the Tamaulipas State (Figure 2) in northeastem Mexico, and described a number of lithostratigraphic units of the Lower Cretaceous of that area, including the Tamaulipas Limestone. Subsequently, Imlay $(1937,1938,1940$, and 1944) reported on the ammonoid faunas, described the Lower Cretaceous stratigraphic formations of northem Mexico, and established the basis for the biostratigraphic ammonite zones and the lithostratigraphic nomenclature applied to Mesozoic rocks of that area until the present. Imlay (1937) also introduced the term "Cupido Formation" to define the lithostratigraphic unit of shallowwater facies preceding the La Peña Formation. Humphrey (1949), described the geology of the Sicra de Los Muertos, close to Saltillo within the State of Coahuila (Figure 2), and provided a detailed description of the Aptian ammonites of the La Peña Formation in that arca. Cantu (1963), proposed an ammonite biozonation for the Aptian series of nothern Mexico, and further extended the correlation to previous biozonal schemes proposed for different areas of the Tethyan realm. Cantu's work marked a major step in Aptian ammonite biozonation because it was the first attempt to develop a detailed biochronologic scheme based on ammonites applicable to that interval of the Lower Cretaceous series of northern Mexico. However, an important problem was raised by Young (1969) who pointed out that even though the Aptian sections of northern Mexico could be easily recognized by their characteristic and abundant ammonite fauna, this stage had an incomplete ammonite zonation. In order to alleviate some of the discrepancies, Contreras-Montero (1977) redefined the biostratigraphic precision of the ammonite biozonation previously established 
by Cantu (1963) for the Aptian of the region. Thus, the ammonite biozonal scheme proposed by Contreras-Montero has been used as the standard for that area of Mexico, since 1977. At issue, however, remained the uncertainty conceming the exact correlation between the Mexican Aptian biozonation and those established for other parts of the world for that time. One of the main problems for broad regional correlations stemmed from apparent taxonomic provinciality during the Aptian.

In fact, although the Aptian had been defined by d'Orbigny (1840), and the French stratotype of that stage has been redescribed in terms of its faunal content, the subdivision and standardization of a proper biochronologic scheme of this stage is still unresolved and contentious for northeastern Mexico. Definition of the Aptian substages established in France on the basis of ammonite assemblages, and on stratigraphic ranges of ammonite taxa are yet to be accurately correlated with their counterparts elsewhere. Attempts to define substage boundaries in Arizona, U. S. A. (Stoyanow, 1949), England (Casey, 1961) and Germany (Kemper, 1970) remained constrained to spatial domains defined by endemic fauna, as was pointed out earlier for the biozonation established for northeastern Mexico (Cantu, 1963; Contreras-Montero, 1977).

Thus, like elsewhere, endemism not only limited the use of the Mexican biochronological schemes for interregional correlation, but they also had the inherent problem of being established on nominal taxa without formal first appearance datum (FAD) and last appearance datum (LAD) references in the stratigraphic horizons. Thus, these zones hardly fulfill the useful requirements of formal biostratigraphic units, because the recognition of these biozones is very difficult to locate precisely in the Aptian stage of northeastem Mexico. Zonal boundary problems most likely stemmed from the intermittent character of the occurrences of the ammonite assemblages, a pattern which will be discussed further in the present work, but was never addressed by previous authors. 
Such intermittence can be better characterized through combined lithostratigraphic and biostratigraphic studies. In fact, a review of the literature on the stratigraphy of northeastern Mexico reveals that considerable effort has mainly been placed on ammonite biostratigraphy. The lithologic relationship has only been considered in most recent studies of the Mesozoic geology of northeastern Mexico. Lehmann, et al. (1998), discussed the possible controlling factors on the cyclostratigraphy of Lower Cretaceous carbonates and evaporites that developed over a topographic high known as the Cupido Platform (Figure 1). Barragan (1999), discussed preliminary data on sedimentary facies and organic carbon variations in Barremian/Aptian sequences of northeastern Mexico.

Based on the present status of ammonite biostratigraphic studies in northeastern Mexico (Cantu, 1963; Contreras-Montero, 1977) it is evident that two main areas of study need to be addressed:

1) How to improve the existing ammonite biozonation, considering constraints associated with a discontinuous spatial and temporal record of the different taxa. The goal would be to obtain a more reliable ammonite biozonal scheme that can be correlated with ammonite zonations elsewhere.

2) Further our understanding of the lithostratigraphic record in northeastem Mexico during the Aptian, which will provide clues on the lithologic relationship between the strata and the fauna. The goal would be to develop a better understanding of the possible causes that controlled intermittent occurrences of the ammonites in relation to their paleobiogcography, as well as the prevailing paleoceoanographic and paleoecologic conditions.

In order to accomplish these goals the present study includes the following: 
1) A detailed biostratigraphic analysis of the ammonites of two Barremian-Aptian sequences of notheastern Mexico. The results of this analysis have led to the construction of a more reliable ammonite biozonal scheme for the study area.

2) A detailed sedimentological analysis of the facies changes, including microfacies studies and temporal variations of the organic carbon/carbonate contents of the two sections. This analysis of the relationships between the vertical distribution of the ammonites and the physical and geochemical variations of the facies helped to characterize the sedimentological regimes that prevailed during Barremian/Aptian time in northeastern Mexico.

The results of this work shed further light on our understanding of the paleoceanographic processes that influenced this area of northeastern Mexico, as well as other parts of the world. 


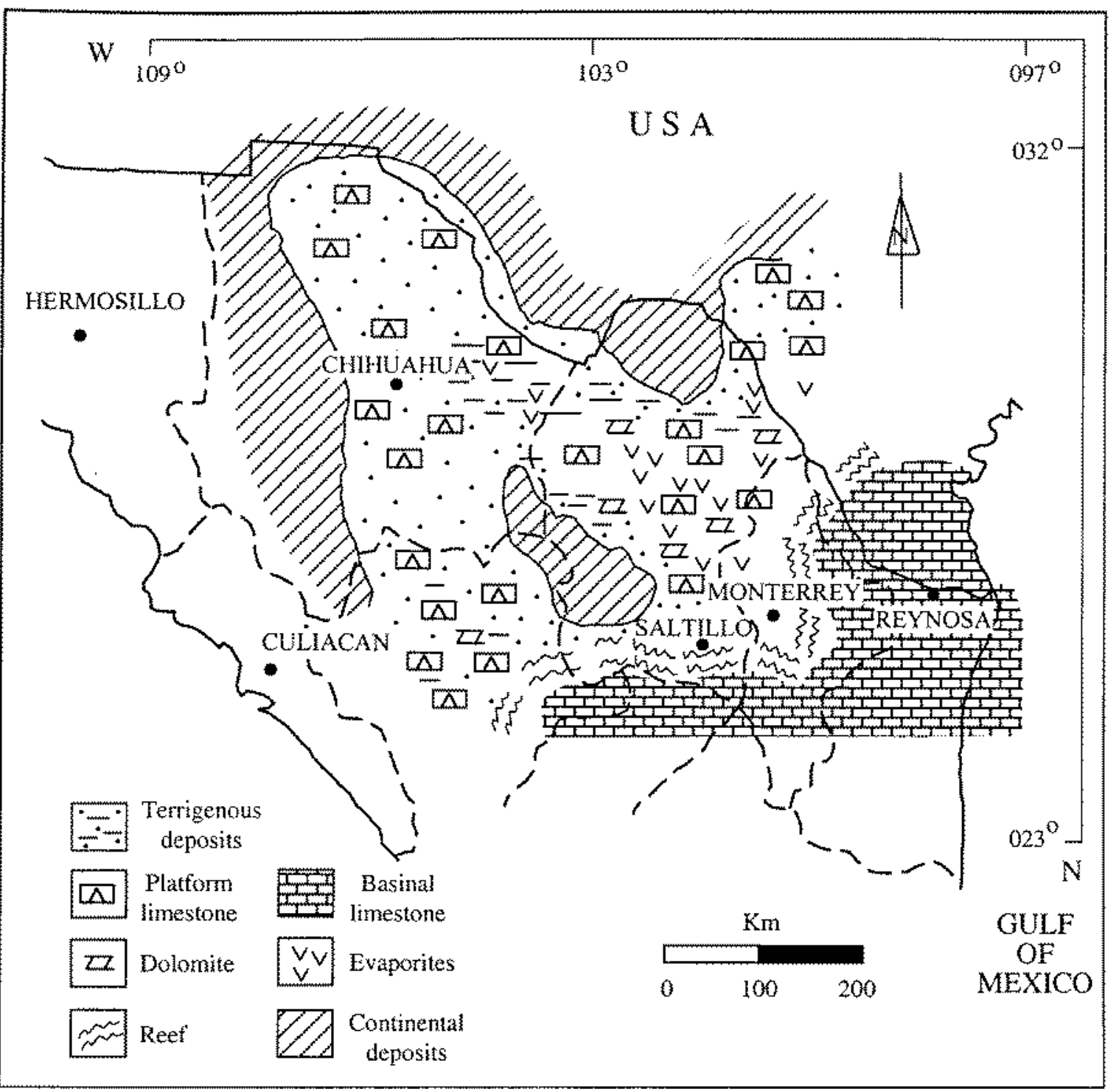

Figure 1. Paleogeography of Neocomian-lower Aptian of northem and northeastem Mexico (After Gonzalez-Garcia, 1976, in Moran-Zenteno, 1994). Dashed lines indicate limits of states, as shown in Figure 2. Platform limestone indicates extension of the Cupido Formation, whereas Basinal limestone indicates extension of its lateral time equivalent Lower Tamaulipas Formation. 


\section{CHAPTER 2. GEOGRAPHIC AND GEOLOGIC SETTING}

Geographically, the study area is located in the region commonly referred to as northeastern Mexico, which includes the states of Nuevo Leon and Coahuila; and parts of the surrounding states of Tamaulipas, San Luis Potosi, Zacatecas, Durango, and Chihuahua (Figure 2). As shown in Figure 3, geographically northeastern Mexico is bounded on the north by the United States, on the west by the Sierra Madre Occidental, on the south by the southern edges of the Central Mesa, the Sierra Madre Oriental, and the Coastal Plain of Northern Gulf of Mexico, and on the east by the Gulf of Mexico coast..

The climate of the region varies from hot to temperate, being dry to semi-arid in the west and humid to sub-humid in the Sierra Madre Oriental and the Coastal Plain of the northern Gulf of Mexico (Moran-Zenteno, 1994). Despite regular summer rains, the overall climatic conditions in the region allow for good rock exposures in river valleys and antecedent streams (Lopez Ramos, 1979).

Geologically, these areas of northeastern Mexico are parts of well defined physiographic provinces, such as the Sierras and Plains of the North, the Mexican Cordillera or Sierra Madre Oriental, the Great Plain of North America, the Coastal Plain of the Northern Gulf of Mexico, and the Central Mesa (Moran-Zenteno, 1994), which are the expression of different structurally complex geologic terranes.

The present study examines two upper Barremian-Aptian stratigraphic sequences located in exposed limbs of open anticlines within this structurally complex area, where the overall topography follows the structural fabric of intensely folded Jurassic and Cretaceous sedimentary rocks. The two sites are here referred to as : 
The Presa Francisco Zarco section (PFZ), located southwest of Torreon City in Durango State, and which is part of the eastern edge of the geologic province known as the Central Mesa; and

The La Boca Canyon section (LBC), located southeast of the City of Monterrey in Nuevo Leon State, and which is part of the folded sedimentary Mexican Cordillera, or Sierra Madre Oriental (Figure 2).

Both localities are characterized by series of folded and imbricated, thrust-faulted Barremian/Aptian limestones, shales, and sandstones that were deformed during the Late Cretaceous-Early Tertiary Laramide orogeny (Humphrey, 1956 a; De Cserna, 1956; De Cserna et al., 1977; Tardy, 1980). 


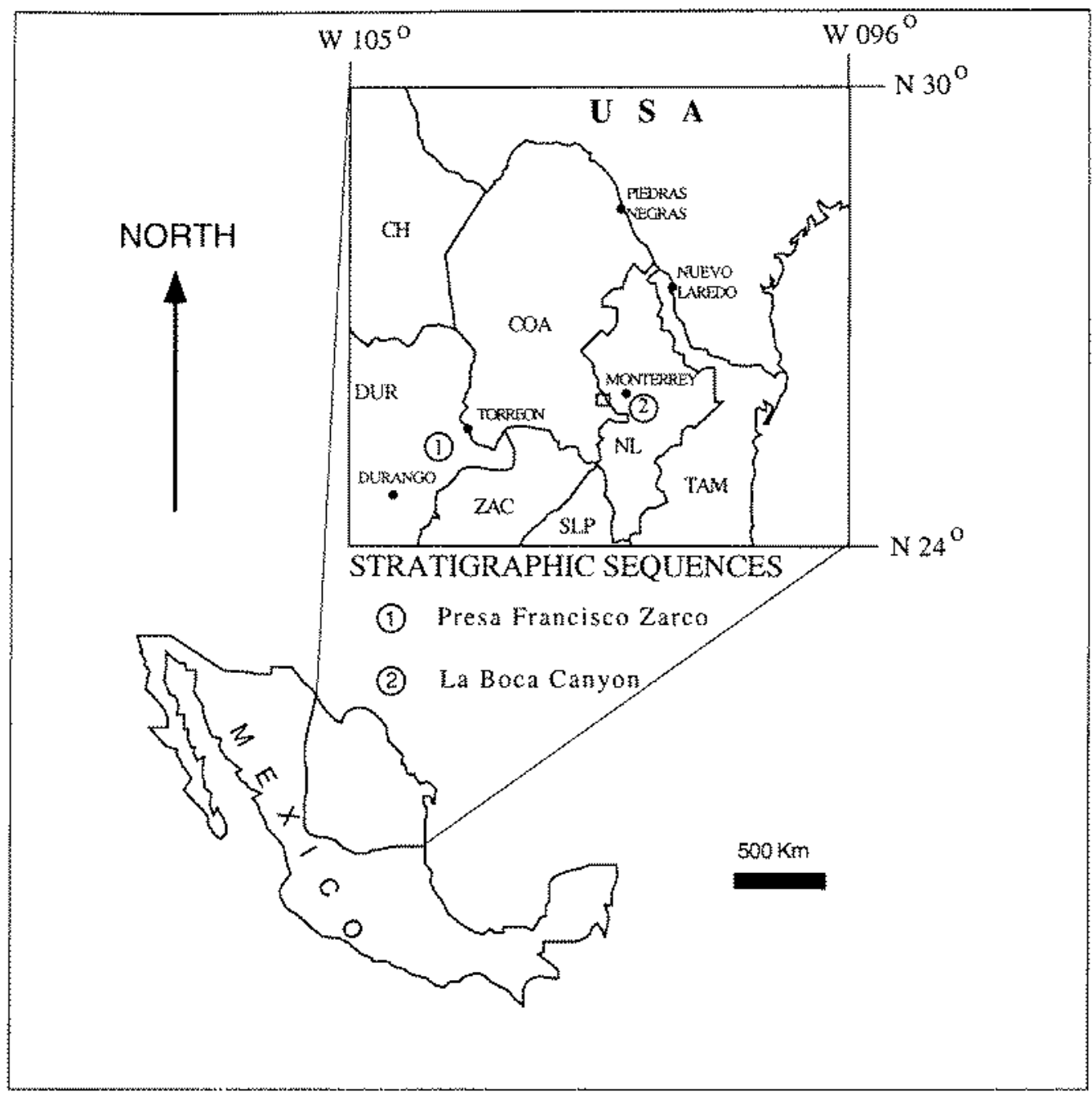

Figure 2. Map of Mexico showing the region referred to as northeastern Mexico, including the location of the stratigraphic sections used in this study. States: 1) $\mathrm{CH}=\mathrm{Chihuahua,2}$ ) COA=Coahuila, 3) DUR=Durango, 4) ZAC=Zacatecas, 5) $\mathrm{NL}=$ Nuevo Leon, 6) TAM=Tamaulipas, 7) SLP=San Luis Potosi. 


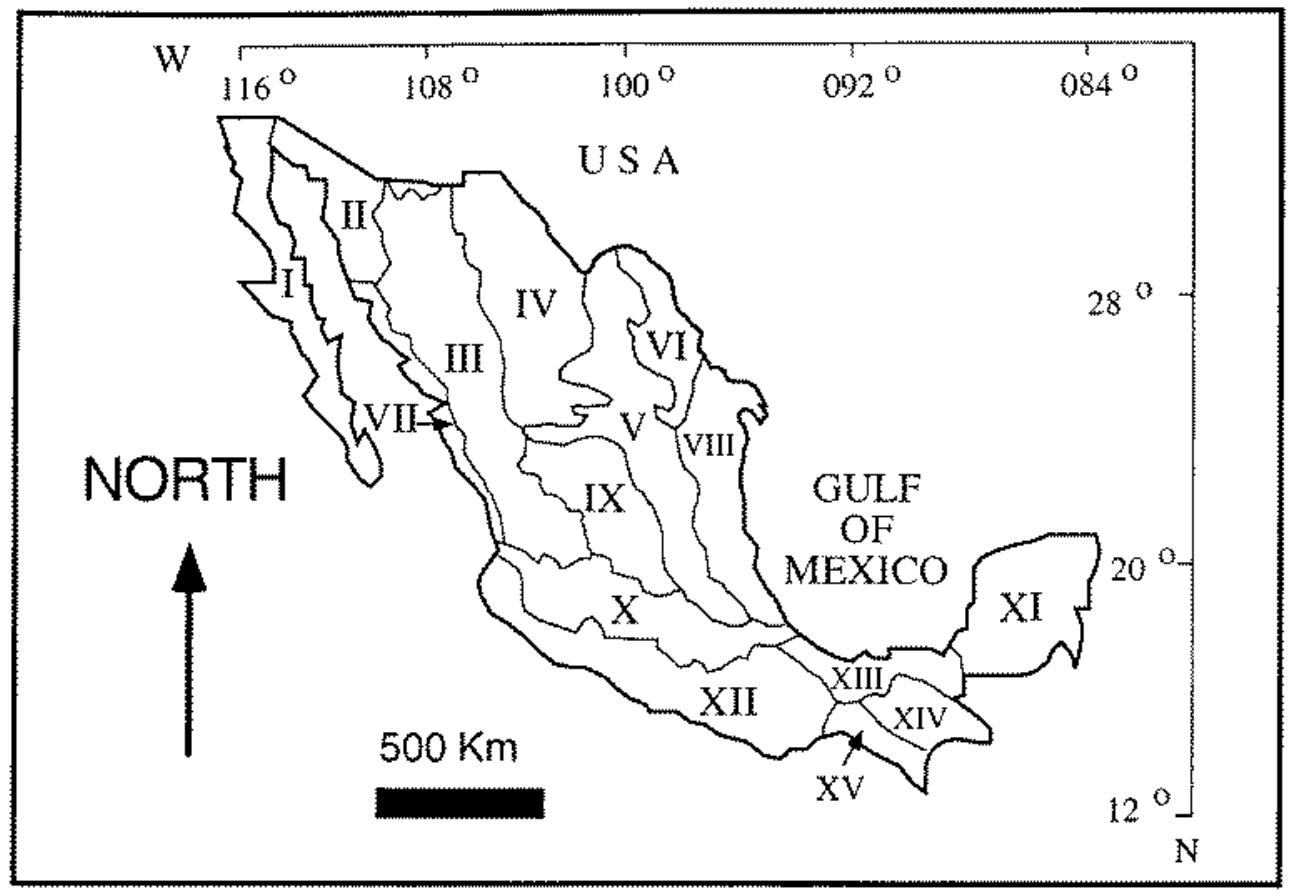

Figure 3. Physiographic regions of Mexico. I) Baja California Peninsula, II) Sonoran Desert, III) Sierra Madre Occidental, IV) Sierras and Plains of the North, V) Sierra Madre Oriental, VI) Great Plain of North America, VII) Pacific Coastal Plain, VIII) Coastal Plain of Northern Gulf of Mexico, IX) Central Mesa, X) Neovolcanic Axis, XI) Yucatan Peninsula, XII) Sierra Madre del Sur, XII) Southern Gulf Coastal Plain, XIV) Chiapas Mountains, XV) Central American Cordillera (After Moran-Zenteno, 1994). 


\section{CHAPTER 3. STRATIGRAPHIC FRAMEWORK}

This chapter discusses a brief overview of current understanding of Lower Cretaceous series of northeastem Mexico and their relationship to the prevaling paleogeographic conditions of that time. Its main purpose is to provide the overall stratigraphic context of the sections studied within the Cretaceous System of northeastern Mexico.

\section{GENERAL STRATIGRAPHIC FRAMEWORK}

It is generally recognized that during the beginning of the Early Cretaceous, the marine transgression that began in the Late Jurassic (Vail et at., 1977), continued throughout the Neocomian and favored the deposition of a heterogeneous carbonate sequence (MoranZenteno, 1994). Continuous westward opening of the Tethys Sea resulted in the development of open marine connections over a broad area, including the proto-Caribbean, which allowed further expansion of contemporary tropical marine environments and the dispersal of the Tethyan biota into the proto-Gulf of Mexico by Early Cretaceous time (Frakes, 1979). From the Hauterivian to the early Aptian, sedimentation in the basins that will become northeastem Mexico was characterized by heterogeneous series of calcareous deposits of different types of facies. Thus, characteristically shallow-water limestones, named the Cupido Formation (Imlay, 1937), were deposited in a broad shallow carbonate platform environment (Conklin and Moore, 1977; Figure 1). These limcstones occur in large parts of the States of Nuevo Leon, Coahuila, and Durango, which are interpreted to have been associated with the Coahuila and Tamaulipas peninsulas, or two important positive paleogeographic elements of Mexico during the Early Cretaceous. The edgc of the Cupido platform developed a rudistid reef lineament (Moran-Zenteno, 1994), whereas coeval open-marine carbonates accumulated beyond the rudistid fore-reef area of the 
Mezosoic Mexican Sea. These limestones are known as the Lower Tamaulipas Formation as defined by Stephenson in 1921 (Ross, 1981).

Medial Aptian series are characterized by widespread shale, marl, or argillaceous limestones that appear in all of northern Mexico and most of the Texas-Louisiana Gulf Coast. The occurrence of this type of facies is remarkably sudden and the change is known in northern Mexico as the "La Peña event", and the representative rock sequences are grouped under the name of the La Peña Formation (Smith, 1981). Similar coeval facies are known as Otates in east-central Mexico, Pearsal! in Texas, and Pine Island in Louisiana. It is surmised that the onset of the La Peña type of facies is related to the influx of fine clastics, coupled with more rapid subsidence that terminated environmental conditions formally known as the Cupido platform (Wilson and Pialli, 1977, Smith, 1981, Goldhammer et al., 1991, and Lehmann et al., 1998).

The stratigraphic sections analyzed in the present study include rock sequences of three formations, namely the Cupido, the Lower Tamaulipas, and the La Peña Formation. Most of the ammonites succession discussed occurs within the thin-bedded limestones and marls of the La Peña Formation.

In the following paragraph further review of the most recent concepts for the definitions of these formations is presented within the current Mexican stratigraphic nomenclature of the Mesozoic series. The Cretaceous System of Mexico is generally grouped as three series (time stratigraphic units), namely from oldest to youngest, Coahuilan, Comanchean, and Gulfian (Bishop, 1970) (Figure 4).

\section{Coahuilan Series}

The term "Coahuila Group" was introduced by Imlay (1940) to refer to all Lower Cretaceous strata older than the biozone of the ammonite known as Dufrenoyia texana, which is characteristic of the lowermost part of the La Peña Formation. The current name 
for this taxon is Dufrenoyia justinae. As indicated by Imlay (1940), this series includes all rocks that were deposited during the span of time before the occurrence of Dufrenoyia justinae, either in the ancient Gulf of Mexico, the Mesozoic Mexican Sea, and any other interconnected waterways. In northeastern Mexico, the Coahuilan series contains three lithostratigraphic units commonly known as the Taraises Formation (Neocomian basinal facies), the Lower Tamaulipas Formation (Barremian-lower Aptian basinal facies), and the Cupido Formation (Barremian-lower Aptian platform facies) (Figure 4). However, in northeastern Mexico the onset of the La Peña Formation is not always coeval with the first appearance datum of Dufrenoyia justinae. In such case, the boundary of the Coahuilan series would have to be placed in different rock units following the order of occurrence of the characteristic ammonite taxon. In order to correct for this discrepancy of the boundary of the Coahuilan series, Humphrey (1949) and Forgotson (1957) redefined the CoahuilanComanchean boundary to correspond to the base of the La Peña Formation. In this way, the top of the Coahuilan Series is coincidental with the limit of a physical entity, or characteristic lithofacies. The present study only discusses the upper part of the Coahuilan series which corresponds to the Cupido Formation and its lateral equivalent the Lower Tamaulipas Formation (Figure 4).

\section{Comanchean Series}

Hill (1887), used the term "Comanchean Series" to define a sequence of Lower Cretaceous strata exposed in central Texas, which can be correlated with several Mexican formal lithostratigraphic units, namely the La Peña (middle-upper Aptian basinal facies), the Upper Tamaulipas, the Aurora, and the Cuesta del Cura Formations. In northern Mexico, the upper boundary with the Gulfian Series has been placed on top of the Cuesta del Cura Formation (Bishop, 1970). Most of these formations are not addressed in the present study 
which focuses only on the lowermost part of the Comanchean series equivalent to the La Peña Formation (Figure 4).

\section{Gulfian Series}

The Gulfian Series is the youngest series of the Cretaceous System (Bishop, 1970) of northeastern Mexico (Figure 4), and is beyond the scope of the present study. The term was introduced by Hill (1887) for all the Cretaceous rocks in the Texas region which lie unconformably on Comanchean strata. In northern Mexico, the Gulfian Series includes the Indidura, the Agua Nueva, the San Felipe, and the Mendez Formations, and the Difunta Group (Bishop, 1970).

\section{BRIEF NOMENCLATURAL IISTORY OF THE FORMATIONS}

Strata of the Lower Cretaceous series studied in the present work and referred to as the Cupido, Lower Tamaulipas and La Peña Formations have a varied nomenclatural history. The initial definitions were often correctly identified based on lithofacies characteristics, but later confusion often occurred when fossil ranges were instead considered to become indices of formational units.

\section{The Cupido Formation}

The term Cupido was first applied by Imlay (1937) to define a unit of "thick-, medium-, and thin-bedded limestones" in the middle part of the Sierra de Parras in Coahuila State, which lies between the underlying Taraises Formation and the overlying La Peña Formation. Humphrey (1949), redefined the Cupido Formation, raising its upper boundary to include the lower member of the La Peña Formation, because the latter had shallowwater components, (unlike the units of the upper member of the La Peña Formation sensu stricto, as will be discussed later). The present study concurs with the views presented by 
Bishop (1970), who argued that the contact between the Cupido and the La Peña Formations is sufficiently distinct and sharp to warrant a stratigraphic separation of the two units. The boundary is characterized by shale, clay, and clayey limestones which characterize the La Peña Formation, abruptly overlying the massive limestones of the Cupido Formation.

Although the change is not that remarkable in the La Boca section (where the La Peña Formation overlies a more open marine deposit, the Lower Tamaulipas Formation), the lithological characteristics of the infrajacent units are also sufficiently different to permit distinction between the two formations as well. Thus, the terminology used in the present work follows the modified concept of the Cupido Formation (Humphrey, 1949).

\section{The Lower Tamaulipas Formation}

The term Tamaulipas Limestone was first used by Stephenson in a private report to the Mexican Gulf Oil Company in 1921 (Ross, 1981), to define all basinal limestones of Albian-Cenomanian age from the Sierra de Tamaulipas located in the southeastern region of Tamaulipas State. Similar limestone series are also found farther southeast in the subsurface of the Tampico Embayment between the states of Tamaulipas and Veracruz. Muir (1936), expanded the concept of the Tamaulipas Limestone to include all Lower Cretaceous strata between the Upper Jurassic and the Upper Cretaceous series, placing the limit below the Agua Nueva Formation, which is included in the lower Gulfian series. This formation represents a basinal facies of the Ancestral Gulf of Mexico (Moran-Zenteno, 1994). In conjunction with this extended concept, the Tamaulipas Limestone was divided into the Lower Tamaulipas and Upper Tamaulipas limestones, separated by a minor interval sometimes ranging from ten to twenty meters, of thinly-bedded, black, shaly limestones referred to as the Otates horizon. This reference horizon was given the formal status of a 


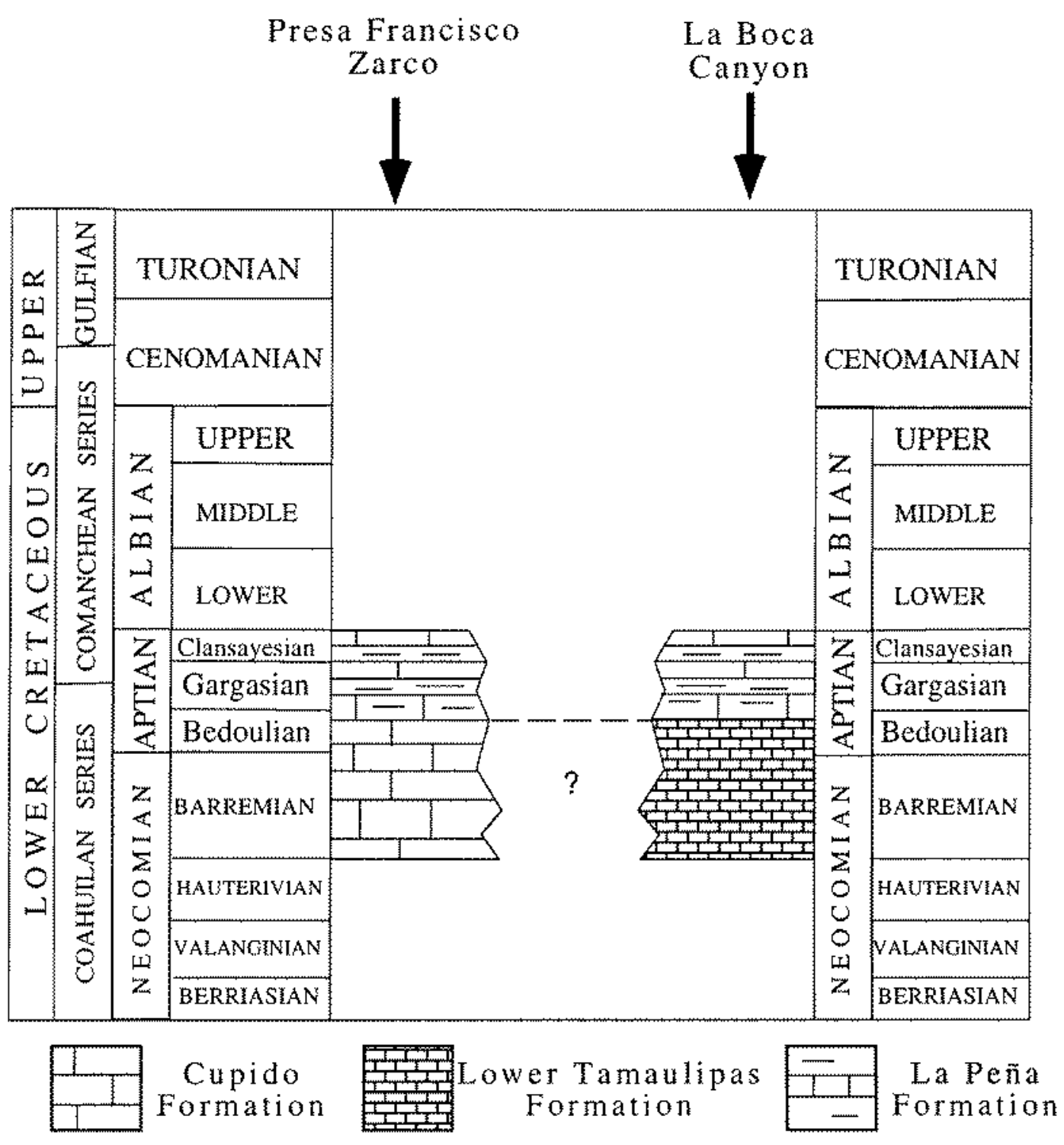

Figure 4. Chronolithostratigraphic correlation of the two stratigraphic sections studied in the present work placed within the stratigraphic framework of northeastern Mexico.

lithostratigraphic unit known as the Otates Formation restricted in practice to areas of eastern Mexico (Diaz, 1953). If the chronostratigraphic position of the Otates Formation of 
eastern Mexico is late Aptian in age (Humphrey, 1949, 1956 b, correlation charts), it would be therefore correlative with the upper part the La Pena Formation of northern and northeastern Mexico. As discussed by Ross (1981), subsequent authors argued differently as to the assignment of names to be applied to the lower and upper basinal limestones and their intercalated shaly, terrigenous-rich facies. Despite the vagaries of the names proposed, it was not until a succession of studies in the 1980's that the nomenclature of the Lower

Cretaceous strata became established. Thus, in the present work the Cupido Formation is recognized as shallow-water platform limestone facies, while the Lower Tamaulipas Formation is its lateral equivalent, or open-marine, pelagic limestone facies underlying La Peña facies in some areas of northeastern Mexico (Smith, 1981; Ross, 1981; MoranZenteno, 1994).

\section{The La Peña Formation}

The name La Peña was originally applied by Imlay (1936, p. 103) to the unit of limestones and shales that lies between the Parritas Formation below and the Aurora Limestone above, located on the western part of the Sierra de Parras in Coahuila State. At these locations the La Peña facies developed different characteristics that allowed Imay to divide the sequence into two members, an about 1400 feet-thick lower member composed of thick limestones ranging between 30 feet-thick to 60 feet-thick, and a 50 to 80 feet-thick argillaceous upper member. Humphrey (1949), redefined and emended Imlay's La Peña Formation, restricting it to "...the lithologically distinct unit of marls, shaly limestones, and shales which carries a late Aptian fauna and which is extensive throughout northern Mexico". Thus, Humphrey's La Peña Formation is synonymous with Imlay's original upper member of the La Peña. As discussed previously, Humphrey (1949) placed Imlay's lower member of the La Peña Formation within the Cupido Formation. Humphrey's usage of the La Peña 
has been accepted by virtually all stratigraphers of the area since that time, and it is adopted for the purposes of this work. 


\section{CHAPTER 4. METHODS AND TECHNIQUES}

In order to accomplish the objectives of this investigation, the methodology of the present research required two phases:

1) field work, including measurement of stratigraphic sections, and sample collection, and

2) laboratory analyses of the samples, including thin section preparation and study, and carbon/carbonate measurements.

\section{FIELD WORK}

Selection of suitable outcrops for the field work for the study of the stratigraphic succession of Barremian-Aptian series was carried out after a search of the literature and initial field reconnaissance. Two Barremian-Aptian stratigraphic sequences were chosen from northeastern Mexico because at these localities outcrops were adequate for the collection of field data, as well as for sample collection. Samples were collected during four field seasons between the summer of 1995 and the summer of 1997. Field recognition of initial physical formational characteristics was based on previously established formal lithostratigraphic units by earlier workers (Imlay, 1936, 1937; Muir, 1936; Humphrey, 1949) in the area of study, as explained in the preceding section of the stratigraphic framework. Detailed observations of the stratigraphic succession include thicknesses, primary and secondary sedimentary features, rock-color (Geological Society of America rock-color chart), paleontological content, and lithologic variations of individual strata of the two sequences, which were plotted on a temporal scale as displayed in the stratigraphic columns shown in Figures 5 and 6 . The sections were measured on a bed-by-bed scale with the use of a metric tape, up to a total thickness of 133 meters at Presa Francisco Zarco, in the State of Durango, and 123 meters at La Boca Canyon, in the State of Nuevo Leon. Unaltered rock samples collected for the purpose of microfacies studies and 
carbon/carbonate analyses were taken and documented for every individual bed of the two sequences. Extensive sampling for the study of ammonites was carried out specifically in the La Peña Fomation at the Francisco Zarco section, because this was the only site where the ammonites occur in significant number at intermittent intervals. Thorough examination of the Francisco Zarco section indicated that periodic occurrence of the ammonites reflects their temporal distribution in these beds rather than an artifact related to possible diagenetic factors.

In contrast to Francisco Zarco, the section studied at La Boca Canyon contains very scarce, poorly preserved and scattered remains of ammonites, such that they were not reliable enough for adequate sampling to permit meaningful correlation.

\section{LABORATORY ANALYSES}

\section{Microfacies Analysis}

Microfacies analyses were carried out primarily following the guidelines of Folk $(1959,1962)$ and Flügel $(1982)$. Rock samples were prepared in thin-sections and studied with a standard petrographic microscope (Olympus BH-2) for further microscopic characterization of the facies succession throughout the two stratigraphic sections of this study. Microfacies determination and their interpretation follow the classification of carbonate rocks by Folk (1962), and Flügel (1982), and the standard microfacies belts as defined by Wilson (1975). Recognition of all paleontological and petrographic components of the rocks was made during the establishment of the microfacies types (Figure 7). Estimation of percentages of allochems were made after the comparison charts for frequency estimations of bioclasts, peloids, ooids, oncoids, and lithoclasts (Fligel, 1982, p. 247-257). Temporal succession of the relative abundance of the best paleoecological indicators namely radiolaria, benthic and planktonic foraminifera was determined by means 
of point-count data at Francisco Zarco section to infer possible changes in the paleoecological conditions (Figure 8). Particular attention was given to these paleoindicators because vertical changes on the relative abundance of these paleontological components, along with the variations of the total organic carbon throughout the stratigraphic sequence (Figure 9), can be interpreted in terms of changes in the productivity of the water column, or in terms of changes on the oxygenation conditions of the bottom waters through time.

Once the vertical succession of microfacies types throughout the stratigraphic sections were identified, they were grouped in packages and plotted against the stratigraphic columns in order to characterize any changes in the sedimentological regimes (Figure 7 ). Photomicrographs of the microfacies were taken with an Olympus photomicrographic system camera PM-10-M, using $35 \mathrm{~mm}$ film format and polaroid film. Representatives of these microfacies have been arranged into plates (Plates 1-46) within Appendix 1 to Ilustrate the typical facies found.

\section{Carbon/Carbonate Analyses}

Relative percentages of the carbon/carbonate content of all samples collected from the two stratigraphic sections were determined with a LECO CR-412 Analyzer. Analyses were performed on a total of 237 samples from the Presa Francisco Zarco section, and a total of 205 samples from the La Boca Canyon section.

\section{Principle of the LECO CR-412 Analyzer}

The LECO CR-412 Analyzer is a non-dispersive, infrared, digitally-controlled instrument designed to measure both organic and inorganic carbon content in a wide variety of organic materials such as coal, coke and oil, as well as some inorganic materials such as soll, cement, and limestone (LECO, 1997). 
Analyses are carried out with samples within the range of 0.025 to 0.5 grams, which are first reduced to a fine powder with a micromill. Each powdered sample is weighed in a combustion boat, which is then placed into the combustion chamber.

The analytical process involves an oxidative-reduction reaction of the powdered material brought to a temperature of $1350^{\circ} \mathrm{C}$ in a pure oxygen environment within the combustion chamber. Once the sample is ignited it releases $\mathrm{CO}_{2}$ because its carbon-bearing compounds break down and free the carbon, which is then oxidized. The design of the combustion system prevents atmosphere from entering the sample combustion zone. The gases are released into a carrier flow and swept through the boat stop to the back of the inner combustion tube, then forward between the inner and outer tubes, allowing the gases to remain in the high temperature zone for a longer period and permit efficient oxidation. From the combustion system, the gases are channeled into two reagent tubes, also called Anhydrone tubes, in a 1:9 mixture of glass wool, and Anhydrone $\left.\left(\mathrm{Mg}_{(\mathrm{ClO}}\right)_{2}\right)$ to remove moisture. The gases then go through a flow controller, which sets their flow to $3.5 \mathrm{l} / \mathrm{min}$, and then directed through an infrared detection cell which measures the concentration of carbon dioxide gas present. The instrument converts these concentration values for each sample to a percentage/ppm value, using an equation present in the software which takes into account the sample weight, calibration of the instrument, and the known moisture value.

\section{Sample Preparation}

Prior to the analysis, all samples had to be reduced to a fine powder with a Spex Mixermicromill, placed into labeled glass vials for their identification, desiccated for one hour and a half at $105^{\circ} \mathrm{C}$, and finally cooled off in a dessicator. 


\section{Calibration of the Instrument}

Before the actual analysis of the samples could begin, the LECO instrument also requires calibration by running an analysis of twenty different weights (from $0.05 \mathrm{~g}$ through $1.0 \mathrm{~g}$ ) of pure $\mathrm{CaCO}_{3}$, defined as the standard for this procedure. The objective of calibration is to set the ability of the instrument to detect a wide range of possible carbon/carbonate content values $(0.01-100 \%)$, and thus to compensate for differences between the total carbon measured and the actual carbon concentration. Once the instrument is calibrated, the actual analyses of the samples to determine their carbon content included two steps.

\section{Analyses}

\section{A. Total Carbon}

A first set of analyses was carried out in order to determine total carbon as follows:

A.1. - An aliquot of $0.25 \mathrm{~g}$ of each sample was weighed into combustion boats, and those weights and the proper identification number of each sample were recorded into the memory of the LECO CR -412 analyzer.

A.2. - As they were weighed, the combustion boats containing the samples were placed into a dessicator to prevent them from adsorbing air moisture.

A.3. - When there were enough samples to run a suite of analyses (each analytical run supports a set of 32 samples at once), the samples were loaded onto a loading rack, which was then placed into position for automated feeding mode to the furnace of the instrument. A.4. - Finally, the analyzer was set on operation to proceed with the analysis, which took about 25 minutes for each run of 32 samples.

\section{B. Total Organic Carbon}

A second set of analyses was necessary for the determination of organic versus inorganic carbon content of the samples. Because the second set of analyses involves samples treated 
with $\mathrm{HCl}$ it required that the $\mathrm{LECO}$ instrument be slightly modified by replacing one of the two reagent tubes, or Anhydrone tubes, with a chlorine trap tube. The analytical steps were as follows:

B.1. - Separate aliquots of $0.25 \mathrm{~g}$ each of all the samples previously analyzed were placed into small glass plates, and treated with a $10 \%$ hydrochloric acid solution for the removal of inorganic components.

B.2. When the reaction ceased the residues were desiccated on a hot plate and placed on labeled glass vials for their identification.

B.3. - The residues were then desiccated for one hour and a half at $105^{\circ} \mathrm{C}$ and cooled off in a dessicator.

B.4. - These samples were then placed into combustion boats for their analysis following the same steps as outlined in A.3 and A.4 above.

\section{Calculation of Organic versus Inorganic Carbon}

The percentage values obtained from the first analyses represent the total carbon content $[\mathrm{TC}=$ inorganic carbon + organic carbon $]$ of each individual sample. The values obtained from the second analyses represent the non-carbonate carbon results, and are here referred to as "Total Organic Carbon" (TOC). The differences between the percentages of the total carbon contents (TC from the first analyses) and the percentages of the "Total Organic Carbon" contents (TOC from the second analyses), therefore represent the total carbon from carbonate, and are here referred to as "Total Inorganic Carbon" (TIC) and could be easily determined as follows:

$\left[(\text { inorganictorganic carbon })_{\text {first anatysis }}\right]=\left[(\text { organic carbon })_{\text {second analysis }}\right]=$ TIC or

$$
\text { TIC }=\text { TC }- \text { TOC }
$$


Results of total organic versus total inorganic carbon of each individual sample were plotted against the two stratigraphic columns to define temporal geochemical characteristics with lithofacies variations (Figures $9 \mathrm{a}+\mathrm{c}$ and 10 ).

\section{Ammonite Biostratigraphy}

The specimens of ammonites collected in the stratigraphic sequence were cleaned and catalogued in accordance with the numbering system used at the Museum of Paleontology of the Institute of Geology at the National Autonomous University of Mexico as follows: Each specimen was assigned a control reference number and its proper stratigraphic level within the section followed, by an initial identification of the taxa at the genus level. The taxonomic concepts used in the present work correspond to those proposed by Wright, et al. (1996). Subsequent identification of species within genera was made using the classifications by d'Orbigny (1840-42), Kilian (1888 b), Hill (1893), Anthula (18991900), Burckhardt (1925), Riedel (1938), Scott (1940 a), Humphrey (1949), Stoyanow (1949), Cantu (1963), Cantu (1976), and Contreras-Montero (1977). The detailed systematic work is presented in chapter VII where the systematic paleontology of the ammonites is discussed. Characteristic specimens of each species were photographed using a MP4 Polaroid copy-stand and a FM2 Nikon with Nikkor $60 \mathrm{~mm}$ macro lens camera system, and printed at a scale of natural size. They are figured in the Plates $47-59$ in Appendix 4.

\section{Ammonite Biochronology}

Upon completion of the taxonomic analysis special emphasis was given to the vertical succession of ammonites for biochronological purpose. The ammonite faunal data at the genus and species levels were used for the recognition of standard Aptian biozones previously established for this area of Mexico (Cantu, 1963; Cantu, 1976: Contreras- 
Montero, 1977). The resulting biochronological scheme presented in this work is based on these previous zonations, updated in accordance with the observations of this study. The ammonite zonation presented in this dissertation is based on the stratigraphic ranges of all identified Aptian species found at Francisco Zarco (Figure 11, in pocket), and conforms to the rules of the North American Commission on Stratigraphic Nomenclature (1983) for the establishment of biostratigraphic units. 


\section{CHAPTER 5. LITHOSTRATIGRAPHY}

The present chapter includes detailed field observation and laboratory results of physical and microfacies characteristics that define the formations in the sections at Presa Francisco Zarco and at La Boca Canyon in northeastern Mexico (Figure 2).

The importance of the data presented in this chapter relies, in that they shed further light in our understanding of the paleoecological and sedimentological processes that prevailed during the time span represented by the incoming biostratigraphic units proposed in this work.

\section{FIELD-SCALE STUDY}

\section{Presa Francisco Zarco, Durango}

The Presa Francisco Zarco section studied in this work is located by a dam in the Sierra E Rosario, along part of the west limb of the NNW-trending breached anticline eroded by the superposed Nazas River, which forms a deep canyon used to build the dam. Excellent exposure along the access road to the dam on the south side of the canyon offers a unique opportunity to study the succession of strata, and follow the sequence up series from the shallow-water facies of the Cupido Formation to a complete series of marly and shaly facies correlative with the facies of entire the La Pena Formation. Thus, 133 meters of this section has been studied along the road, where there is no stratigraphic interruption, except for minor thrust faulting that disrupted stratigraphic levels 47,48 , and 49 . The upper limit of the sequence was taken at a major thrust fault where layers were intensely deformed and overlain by the thickly bedded lower Albian limestones of the Aurora Formation.

The Presa Francisco Zarco sequence studied consists of a measured section of 133 meters of interbedded units of dark gray (N3) to black (N1) limestones (Figs. 5 and 7). The lower 
78 meters includes limestone facies of the upper part of the Cupido Formation characterized by the conspicuous presence of randomly oriented rudist fragments, and the upper 55 meters consists of predominately shaly facies including the entire record of the La Peña Formation (Figures 5 and 7). A sharp change in facies characterizes the boundary of the two formations, as discussed in the preceding section on the Stratigraphic Framework of this work.

The Cupido Formation at this locality is characterized by a continuous superposition of dark gray (N 3) to black (N 1) limestones, with thicknesses that vary from as little as $17 \mathrm{~cm}$ within the basal part of the section (stratigraphic level PFZ-31), to up to $625 \mathrm{~cm}$ in its upper part (stratigraphic level PFZ-59 a-e) (Figure 5). Some of the contacts between individual strata within this formation are wavy.

The contact between the Cupido and the La Peña Formations is sharp and very distinctive, as it can be recognized at the base of the first marly horizon (stratigraphic level PFZ-60) of the La Peña facies (Figure 5). The marly horizon is deposited directly on top of the massive $625 \mathrm{~cm}$-thick limestone containing abundant scattered rudist fragments and benthonic foraminifera (stratigraphic level PFZ 59 a-e), which represents the uppermost level of the Cupido facies.

The La Peña Formation corresponds to the upper 55 meters of the section, and consists of an alternation of dark gray (N 3$)$ to black (N 1$)$ limestones, and light olive gray (5 Y 5/2) to dusky yellow (5 Y 6/4) clays, marls, and marly limestones. The individual thicknesses of the strata within this formation, range from $5 \mathrm{~cm}$ (stratigraphic level PFZ-64) to $40 \mathrm{~cm}$ (stratigraphic level PFZ-80) among the marly and clayey layers, whereas the limestones vary from $8 \mathrm{~cm}$ (stratigraphic level PFZ-63) up to $190 \mathrm{~cm}$ (stratigraphic level PFZ-190) (Figure 5). One of the most interesting aspects of the La Peña Formation at this site, is its abundant ammonite fauna content, which are fairly well-preserved. Collectively their occurrence is consistent within the formation, but it is important to emphasize that the 
stratigraphic record of these macrofossils is characteristically intermittent throughout the facies of the La Peña. Ammonites are consistently more constant and abundant in the marly and clayey layers, and rarely found in pure limestones.

The microfacies results concerning the texture and petrologic composition of the strata characteristic of both formations will be reported and discussed later in the microfacies section of this chapter.

\section{La Boca Canyon, Nuevo Leon}

The La Boca Canyon section is located in the southern region of the Sierra Cerro de la Silla, and along the road on the north side of the canyon across from the dam built at the canyon formed by the superposed Rio San Juan. Structurally, the section is part of the west limb of the north-northwest trending anticline of the anticlinorium series of the eastern Sierra Madre Oriental (Figure 3). Although the sequence is not as well exposed as the one at Presa Francisco Zarco in Durango, because substantial areas are covered by soil and vegetation, there are sufficient outcrops along the road to assemble a 123 meters measured section that includes the uppermost Barremian (Lower Tamaulipas Formation) and most of the Aptian (La Peña Formation), as discussed in the present work (Figure 6).

The Lower Tamaulipas Formation shown in figure 6 occurs in the lower 11.5 meters of the section, and consists of a monotonous strata of dark gray (N 3) to black (N 1) finegrained limestones, with varied thicknesses between $17 \mathrm{~cm}$ (stratigraphic level LB A-9) and $248 \mathrm{~cm}$ (stratigraphic level LB A-1) (Figure 6). Contacts between individual beds within this formation are commonly stylolitic. 


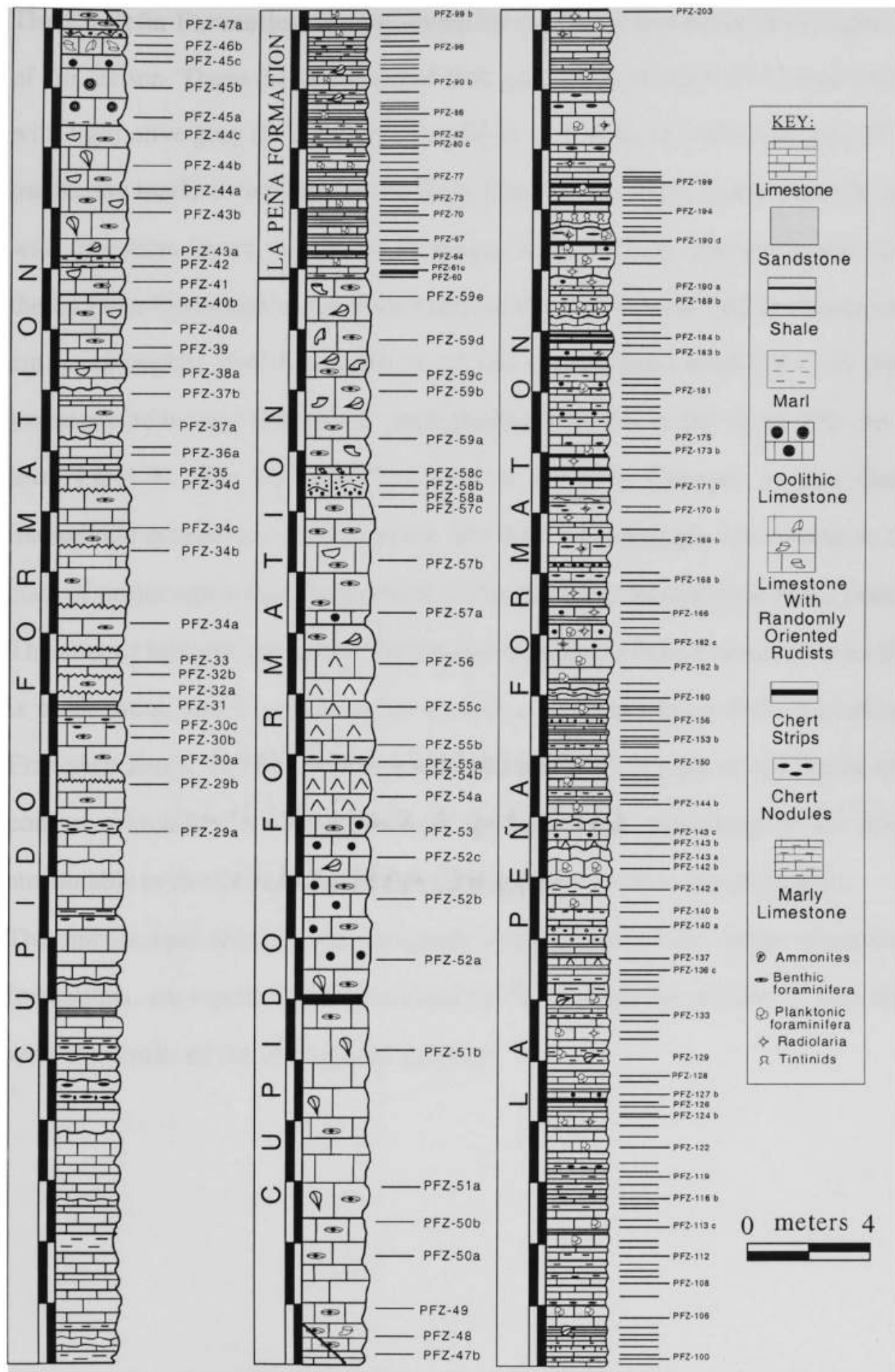

Figure 5. Stratigraphic column showing thicknesses and physical characteristics of individual strata throughout the sequence at Presa Francisco Zarco, Durango. 
The La Peña Formation is represented by the facies that occur in the upper 111.5 meters of the section. These facies consist of dark gray (N 3) to black (N 1) limestones, alternating with light olive gray $(5 Y 5 / 2)$, dusky yellow (5 Y 6/4), or yellowish gray $(5 \times 7 / 2)$ clays, marls, and marly limestones. At La Boca Canyon, the marly layers alternate less frequently with limestone layers than at the Francisco Zarco section. The marly and clayey layers of the La Peña Formation at La Boca Canyon show individual bed thickness ranging from 5 $\mathrm{cm}$ (stratigraphic level LB A-20) to $27 \mathrm{~cm}$ (stratigraphic level LB C-2) (Figure 6). The limestone beds vary from $8 \mathrm{~cm}$ (stratigraphic level LB A-19) up to $198 \mathrm{~cm}$ (stratigraphic level LB I-9). The La Peña Formation at La Boca Canyon, is also characterized by intermittent occurrence of ammonites, but they are strikingly less abundant and in poorer state of preservation than those found within the same formation at Presa Francisco Zarco. The contact between the Lower Tamaulipas and the La Peña Formation at La Boca Canyon, is gradational, and therefore not as evident as the Cupido/La Peña formational contact at Francisco Zarco. In fact, there is no apparent overall change on the facies type across the contact, which can be recognized only by the sudden appearance of the first marly layer attributable to the La Peña Formation (stratigraphic level A-12) (Figure 6).

The microscopic textural and petrologic composition of the strata characteristic of both formations, are reported and discussed in the subsequent section of this chapter dealing with the results of the microfacies analyses. 

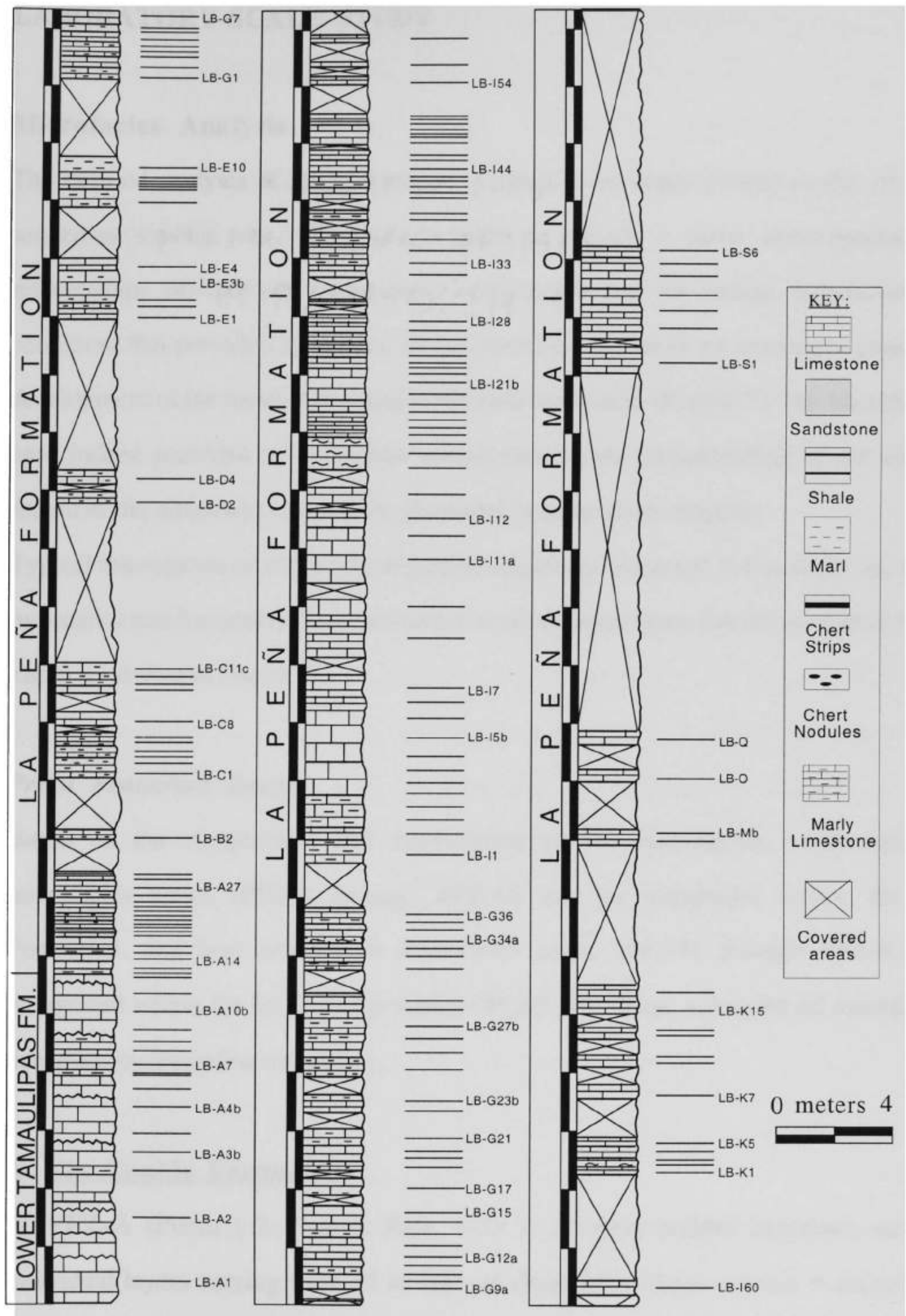

Figure 6. Stratigraphic column showing thicknesses and physical characteristics of individual strata of the stratigraphic sequence at La Boca Canyon, Nuevo Leon. 


\section{LABORATORY:SCALE STUDY}

\section{Microfacies Analysis}

The detailed analysis of the succession of microfacies types present in the stratigraphic sequences studied was carried out in order to provide a better understanding of the relationships between the microscopic components and the overall paleoenvironmental conditions that prevailed at the time of accumulation. As these environments controlled the development of the facies delineated in the field-scale units (Figure 7), the microfacies data have indeed provided an invaluable complement to the understanding of the intermittent record of the ammonites, as will be discussed in subsequent chapters.

Typical microfacies of the two stratigraphic sequences discussed in this study are described by locality and formation. The succession of microfacies types for the section at Francisco Zarco is shown in Figure 7.

\section{Presa Francisco Zarco}

Based on the composition and microtexture of the microfacies, seven subunits or microfacies zones (PFZ-A through PFZ-G) can be recognized within the Cupido Formation, and four subunits or microfacies zones (PFZ-H through PFZ-K) can be recognized within the La Peña Formation (Figure 7). These sub-units of microfacies are described by formation as follows:

\section{A. The Cupido Formation}

1. PFZ-A (Plates 1-2; Plate 3, Figs. 1-3): A 22-meter bedded limestone series, with individual layers varying from 25 to $100 \mathrm{~cm}$ thick. Microfacies subunit A corresponds to the thickness between stratigraphic level PFZ-29a and stratigraphic level PFZ-43c (Figure 7). It consist of biocalcilutites composed of about 40 to $50 \%$ of bioclasts in a micritic 
matrix. Bioclasts represent $80 \%$ of the allochemical composition, among which this facies is rich in benthonic foraminifera of the miliolid group (40\%), ostracods $(20 \%)$, echinoid $(20 \%)$, mollusk $(10 \%)$, and crinoid fragments $(10 \%)$. The remaining $20 \%$ of the allochems correspond to terrigenous materials, which are a fundamental part of the allochthonous constituents (Figure 9 a-c and Plate 8). In some cases, the micritic matrix has been diagenetically altered to secondary sparry calcite cement (Plate 2, Fig. 8).

2. PFZ-B (Plate 3, Fig. 4, Plate 4): This microfacies zone consists of a 2.5 -meter bedded limestone series with individual layers varying in thickness from $20 \mathrm{~cm}$ to $65 \mathrm{~cm}$. This zone corresponds to the interval between stratigraphic level PFZ-43c and stratigraphic level PFZ-45a (Figure 7). These limestone layers consist of an alternation of extensively bioturbated, pelloidal calcarenites with common milliolid benthonic foraminifera. Pellets and benthic foraminifera are clearly dominant and comprise about $80 \%$ of the allochems. Intraclasts, crinoid, bryozoan, and echinoid fragments are also characteristic of this microfacies, and they constitute the remaining $20 \%$ of the allochems. The matrix is micritic except on the areas that are extensively bioturbated, where the microcrystalline calcite has been altered to secondary sparry calcite cement (Plate 4, Figs. 3-4).

3. PFZ-C (Plates 5-6): Microfacies zone C consists of a 4-meter bedded series of biocalcarenites with oolites and algal fragments. It corresponds to the interval between stratigraphic level PFZ-45a and stratigraphic level PFZ-45c (Figure 7). Oolites represent 90 $\%$ of the allochems, whereas algal fragments make up the remaining $10 \%$. The nucleus in the oolites mainly consists of miliolid benthonic foraminifera, but in some cases nuclei may also consist of terrigenous grains or mollusk fragments. All the strata grouped under this microfacies package display sparry calcite cement (Plates 5-6). 
4. PFZ-D (Plates 7-11): A 13.5-meter bedded series of limestones with individual layers between $80 \mathrm{~cm}$ and $400 \mathrm{~cm}$ thick. This microfacies zone corresponds to the interval between stratigraphic level PFZ-45c and stratigraphic level PFZ-51b (Figure 7), and consists of matrix-supported biocalcirudites with randomly oriented rudist fragments (Plate 7, Figs. 1-3). A 30-centimeter thick pelloidal calcarenite occurs at 1.2 meters above the lower boundary of this microfacies package (Plate 8). The upper part of this microfacies consists of common intraclasts, echinoid fragments, miliolid and orbitolinid benthonic foraminifera, which altogether make up about $60 \%$ of the allochemical composition. These allochems are embraced by a micritic matrix. In some cases, the facies are partially dolomitic (Plate 9, Fig. 2).

5. PFZ-E (Plate 12): A 6-meter bedded limestone series with thickness of individual layers between $30 \mathrm{~cm}$ and $200 \mathrm{~cm}$. This microfacies zone corresponds to the interval between stratigraphic levels PFZ-51b and PFZ-53 (Figure 7), and consists of grainsupported biocalcarenites with pellets $(50 \%)$, diverse benthonic foraminifera $(10 \%)$, mollusk $(20 \%)$, echinoid $(10 \%)$, and crinoid $(10 \%)$ fragments. These facies display microsparitic calcite cement.

6. PFZ-F (Plate 13, Figs. 1-2): A 5.5-meter cluster of dolostone beds, with individual layers varying in thickness from $45 \mathrm{~cm}$ to $100 \mathrm{~cm}$. Microfacies zone $\mathrm{F}$ corresponds to the interval between stratigraphic level $\mathrm{PFZ}-53$ and stratigraphic level PFZ-56 (Figure 7). These layers can be described microscopically as non-fossiliferous dolostones with coarse crystalline texture (Plate 13, figure 2) and isotropic fabric.

7. PFZ-G (Plate 13, Figs. 3-4; Plates 14-22): This microfacies zone is the uppermost level of facies attributable to the Cupido Formation at the Presa Francisco Zarco section. It 
consists of 9 meters of biocalcilutite beds with individual layers varying in thickness from $97 \mathrm{~cm}$ to $250 \mathrm{~cm}$, and corresponds to the interval between stratigraphic levels PFZ-56 and PFZ-59e (Figure 7). This microfacies zone is characteristically very rich in miliolid benthic foraminifera $(50 \%)$, intraclasts $(5 \%)$, pellets $(10 \%)$, echinoid $(15 \%)$ and ostracod $(15$ $\%$ ) fragments. This zone also contains some bioclasts that are not typically associated with the rest of the allochems of this type of facies, as for example, stratigraphic levels PFZ-57 c (Plate 14, Fig. 7), PFZ-58 c (Plate 16, Fig. 1), PFZ-59 a (Plate 17, Fig. 2), and PFZ-59 b (Plate 17, Fig. 7), which contain thin-shelled benthonic foraminifera of the lagenid group, which have a rather wide range of depth habitats, including more open-marine environments. These allochems represent the remaining $5 \%$ of the bioclastic composition.

\section{B. The La Peña Formation}

8. PFZ-H (Plates 23-24): This microfacies zone forms the basal unit of the La Peña Formation, and corresponds to the interval between stratigraphic levels PFZ-59e and PFZ64 (Figure 7), which consists of 1 meter of relatively thin beds as compared to the infrajacent Cupido Formation. The beds vary in thickness from $7 \mathrm{~cm}$ to $33 \mathrm{~cm}$ including an alternation of biocalcilutites and soft marly horizons. The biocalcilutites are composed of about $20 \%$ to $30 \%$ bioclasts scattered in a micritic matrix. The bioclasts mainly consist of miliolid and orbitolinid benthonic foraminifera, and very fare (about $2 \%$ to $5 \%$ ) other foraminifera (Plate 23, Fig. 9; Plate 24, Figs. 4, 6). This microfacies is characterized by the absence of the rudistids fragments and contains the first stratigraphic record of the ammonites, here represented by Dufrenoyia justinae in the section (Figure 7).

9. PFZ-I (Plates 25-31): The second microfacies zone identified in the La Peña Formation is a well developed series of 32 meters of biocalcilutite beds with individual layers varying from $10 \mathrm{~cm}$ to $40 \mathrm{~cm}$ thick. It corresponds to the interval between stratigraphic levels PFZ- 
64 and PFZ-162b (Figure 7). Microscopically the allochems include: planktonic foraminifera (Plate 25, Figs. 2 to 6; Plate 27, Figs. 2, 5-6, 8-9; Plate 29, Figs. 2-5; Plate 30, Figs. 1-2, 5, 7-8), benthonic foraminifera (Plate 27, Fig. 4), intraclasts (Plate 26, Fig. 3), very rare ostracods (Plate 27, Fig. 7), fragments of echinoids (Plate 27, Figs. 10-11). An important aspect of this microfacies package is the abundance of terrigenous components (in some cases between $20 \%$ and $30 \%$ of the total components). Radiolarians occur at stratigraphic interval PFZ- 130 (Plate 28, Fig. 1). Ammonites occur in macro-, as well as micro-scale fragments, and they are also a common constituent of rocks of this facies (Plate 28, Fig. 3; Plate 29, Fig. 7; Plate 30, Fig. 4; Plate 31, Fig. 10). The facies are partially dolomitic at some levels, such as stratigraphic levels PFZ-137 (Plate 29, Fig. 1) and PFZ-143 $b$ (Plate 30, Fig. 5). Finally, another important aspect of this microfacies package, is that occasionally, it also contains biocalciluties with abundant peloids (about 40 $\%$ of the rock composition), an example of this textural change is seen at stratigraphic level $143 \mathrm{c}$ (Plate 30, Fig. 6).

10. PFZ J (Plates 32-34): Microfacies zone $\mathrm{J}$ includes 14.5 meters of bedded biocalcilutites with layers varying from $10 \mathrm{~cm}$ to $90 \mathrm{~cm}$ thick. It corresponds to the interval between stratigraphic levels PFZ 162b and PFZ-191 (Figure 7). This facies contains about $50 \%$ biogenic allochems and $50 \%$ terrigenous materials. Among the biogenic components radiolaria comprises about $60 \%$ (Plate 32, Figs. 1-3, 5; Plate 33, Fig. 8; Plate 34, Fig. 5), whereas peloids and planktonic foraminifera represent about $20 \%$ each (cf. Plates 32, 33, 34). Most of the original micritic matrix appears altered to secondary microsparitic calcite. Ammonites occur in macro-, as well as micro-scale fragments in this unit as well. The Last Appearance Datum (LAD) of the stratigraphic records of the ammonites occurs within this microfacies subunit, and it corresponds to the last stratigraphic record of Hypacanthoplites cf. leanzae at stratigraphic level PFZ-190 d. 
11. PFZ-K (Plates 35-36): Microfacies zone $\mathrm{K}$ is the topmost microfacies unit defined at the Francisco Zarco section. It consists of 7.5 meters of bedded biocalcilutites varying in thickness between $10 \mathrm{~cm}$ and $90 \mathrm{~cm}$. It coincides with the interval between stratigraphic levels PFZ-191 and PFZ-203 (Figure 7). Allochems of this facies consist of scattered planktonic foraminifera (Plate 35, Figs. 2, 4-5, and 8; Plate 36, Figs. 1-2, 4), radiolaria (Plate 35, Fig. 8; Plate 36, Figs. 1-4), tintinids (Plate 35, Figs. 3, 6-7), and occasional mollusk fragments. Also unusual in this microfacies is the abundance of black organic matter as can be seen in all the sections shown in Plates 35 and 36 . There is no record of ammonites within this microfacies subunit.

To further complement the analysis of the vertical evolution of the microfacics at Presa Francisco Zarco, temporal succession of the relative abundance of well established paleoecological indicators such as radiolarians, benthic and planktonic foraminifera was determined by means of point-counts (Figure 8). Particular attention was given to these paleo-indicators because vertical changes in the relative abundance of these components, along with the variations of the total organic carbon (Figures $9 \mathrm{a}-\mathrm{c}$ and $10 \mathrm{a}-\mathrm{c}$ ) throughout the stratigraphic sequence, can be interpreted in terms of temporal productivity changes in the water column, as well as changes in the oxic-dysoxic conditions of the bottom waters.

\section{La Boca Canyon}

As previously discussed, the 123-meter section studied at La Boca Canyon comprises 11.5 meters of the upper part of the Lower Tamaulipas Formation, overlain by 111.5 meters of the La Peña Formation. Typical microfacies zones could not be defined to characterize the temporal differences in these two formations, which on the whole are lithologicaly similar. Nonetheless, the characteristic halmark of the La Peña Formation is the increase in 
terrigenous components, as can be seen in the fluctuations of the carbonate content (Figure $10 \mathrm{a}-\mathrm{c})$.

\section{A. The Lower Tamaulipas Formation}

This formation at La Boca Canyon generally consists of a monotonous series of biocalcilutites (stratigraphic levels LB A*1 through LB A-11; Figures 6 and 7; and Plates 37-39). Allochems comprise essentially planktonic and benthonic foraminifera, radiolarians, intraclasts, terrigenous components, echinoid, mollusk, and ostracod fragments. These rocks also contain some bioclasts of unknown origin (Plate 37, Figs. 3 , 7).

\section{B. The La Peña Formation}

This formation at La Boca Canyon can be associated with microfacies of stratigraphic levels LB A-12 through LB S-6 (Figure 7) (Plates 40-46). The microfacies are relatively monotonous throughout, and are similar to those of the infrajacent Lower Tamaulipas Formation previously described. However, as stated before, similar to what has been found in the sequence at Presa Francisco Zarco, one of the main differences between the two formations remains in the relative amount of the terrigenous components. Furthermore, high concentrations of organic matter from stratigraphic level LB E-1 to stratigraphic level LB I-30 (Plates 42-44; Plate 45, Fig. 1), are a common trait identified in the La Peña Formation at both sites. Finally, the presence of belemnite rostra in the upper part of the La Peña Formation (Plate 44, Figs. 2-3, 6-7) at La Boca Canyon is another characteristic of these microfacies which distinguishes it from those of the Lower Tamaulipas Formation. It should also be pointed out that belemnite rostra have not been found in the microfacies of the La Peña Formation at Francisco Zarco. 


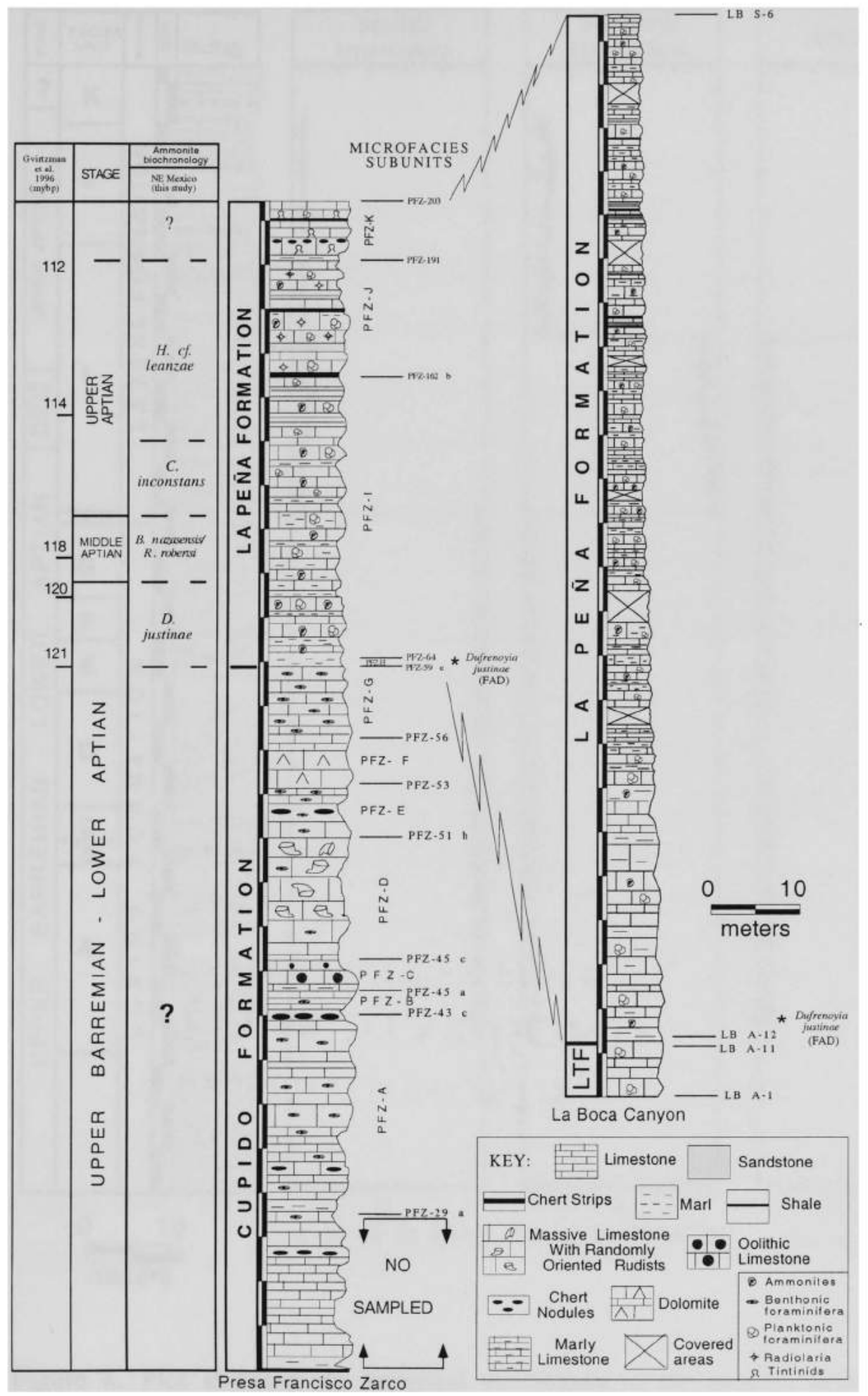

Figure 7. Stratigraphic columns displaying the distribution of microfacies types along the two stratigraphic sequences of this study. LTF $=$ Lower Tamaulipas Formation. 


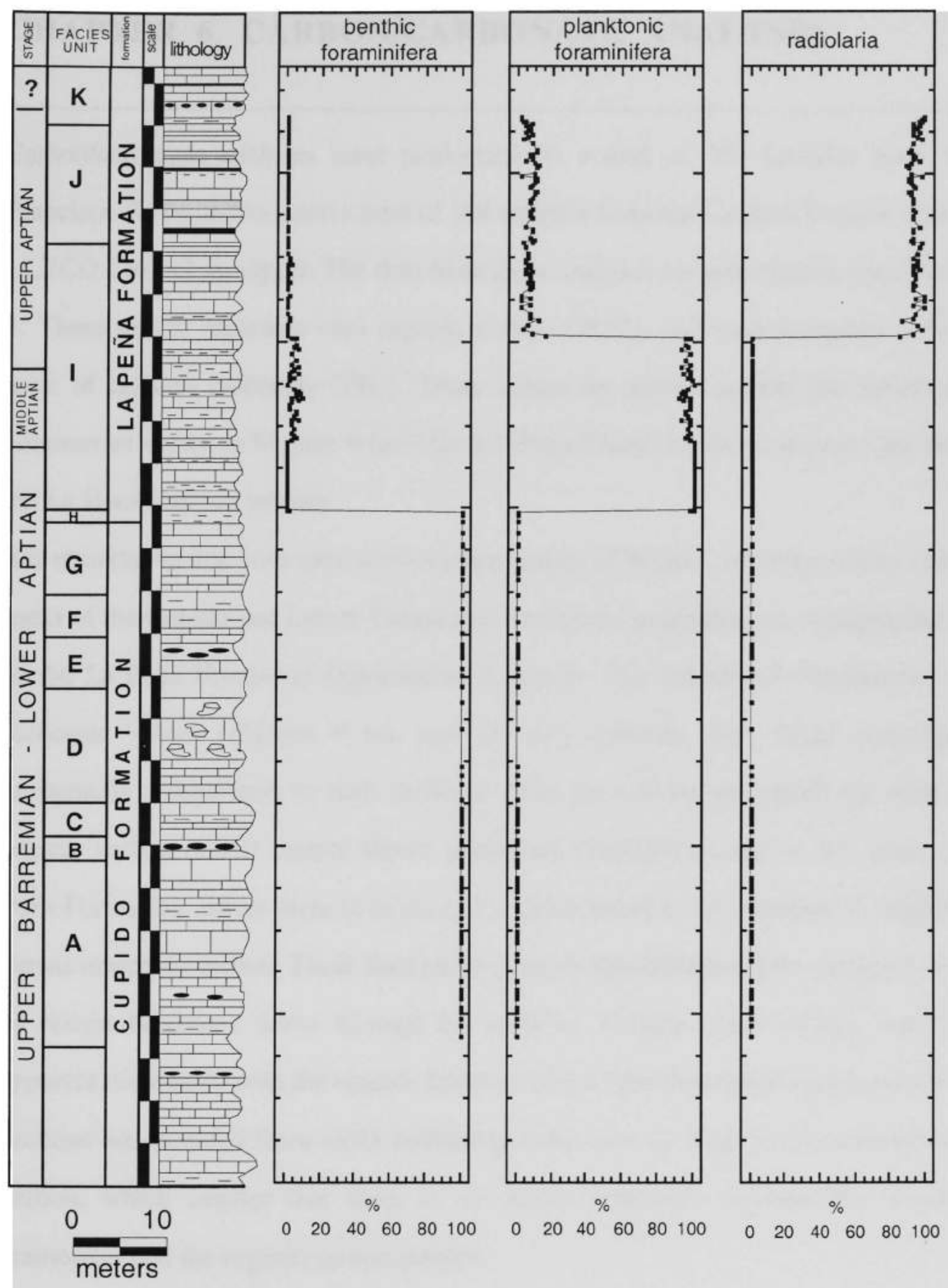

Figure 8. Plot showing the temporal succession of the relative abundance of benthic foraminifera, planktonic foraminifera, and radiolaria, throughout the stratigraphic sequence at Francisco Zarco section. 


\section{CHAPTER 6. CARBON/CARBONATE ANALYSES}

Carbon/carbonate analyses were performed on a total of 237 samples from the Presa Francisco Zarco section, and a total of 184 samples from the La Boca Canyon section using a LECO CR-412 Analyzer. The data from those analyses are presented in appendices 2 and 3. These results represent total organic carbon (TOC), and total inorganic carbon in the form of calcium carbonate (TIC). These values are plotted against the lithostratigraphic columns as shown in Figures 9 (a-c) for the Presa Francisco Zarco section, and 10 (a-c) for the La Boca Canyon section.

It is remarkable that both sites show similar pattem of higher carbonate values (TIC) in the rocks of the Cupido and Lower Tamaulipas Formation preceding the stratigraphic horizons of the La Peña Formation (Appendices 2 and 3). The intermittent fluctuations of lower carbonate values (Figures $9 \mathrm{~b}-\mathrm{c}$ and $10 \mathrm{a}-\mathrm{c}$ ) coincide with strata containing more terrigenous components in both sections. Also, as will be discussed for each site, the organic carbon (TOC) content shows significant fluctuations only in the strata of the La Peña Formation, where there is an inverse relation between the variation in organic carbon versus inorganic carbon. These fluctuation patterns also influenced the presence or absence of certain benthonic fauna through the sections. Despite these marked variations and apparent correlation with the benthic fauna in the La Peña Formation, ammonites in the two sections are recorded from rocks containing either low or high concentrations of organic carbon, which implies that there is no direct correlation between the occurrence of ammonites and the organic carbon content.

\section{PRESA FRANCISCO ZARCO}

The lowermost part of the Cupido Formation in the Francisco Zarco section, the interval between stratigraphic levels PFZ-29a and PFZ-44a, shows total organic carbon values 
oscillating between $5.15 \%$ (level PFZ-29b) and 1.13 (level PFZ-42) (Figure 9+a; Appendix 2). This interval is correlative with microfacies subunit PFZ-A (Figure 7) Increase of the total organic carbon (TOC), from less than $1 \%$ to more than $5 \%$ (Fig. 9-b) is synchronous with changes from well diversified benthic foraminifera assemblages of the Cupido Facies (microfacies subunits PFZ-B through PFZ-G, Figure 8) and lowermost part of the La Peña Formation (microfacies subunit PFZ-H, Figure 8), to a decrease in benthic organisms in the marly and shaly limestones of the La Peña Formation (microfacies subunit PFZ-1, Figure 8). Temporal changes of the carbon/carbonate content in the different stratigraphic units are particularly evident in Figure 9-a and 9-b, between the intervals of stratigraphic levels PFZ-43c and PFZ-59e (subunits B through G of the Cupido Formation), and stratigraphic levels PFZ-59e and PFZ-64 correlative with the lowermost microfacies subunit of the La Peña Formation. The overall organic carbon content of the interval including the Cupido Formation remains below $1 \%$, except for two recorded positive peaks at stratigraphic levels PFZ-58a and PFZ-59b with values of 4.58 and 6.23 $\%$, respectively (Figure 9-b, and Appendix 2). These marked increase of organic carbon within the uppermost Cupido facies were isolated events that heralded a more constant pattern of increased TOC values throughout the La Peña Formation.

As can be seen on Figure $9-b$, the first significant increase in organic carbon content at Francisco Zarco occurred between stratigraphic levels PFZ-62 and PFZ-65 (Appendix 2), which is slightly above the Cupido/La Peña formational contact, and close to the appearance of the first open marine facies namely microfacies subunit 1 .

The stratigraphic interval between levels PFZ-64 and PFZ-162b defined as subunit $I$ shows three significant variations in the total organic carbon content. The lower part of microfacies subunit 1 corresponding to the interval between stratigraphic levels PFZ- 64 and PFZ-100 is characterized by a constant increase of the total organic carbon content that fluctuates between 3 and $8 \%$. (Figures 9-b and 9-c, and Appendix 2). The next suprajacent zone 
between levels PFZ-101 and $136 \mathrm{~b}$ is characterized by an overall drop in the total organic carbon content, with values between $0.01 \%$ (stratigraphic level PFZ-104) and $1.43 \%$ (stratigraphic level PFZ-136b) (Figure 9-c, and Appendix 2). The upper part of microfacies subunit I (Figure 7), comprising the interval between stratigraphic levels PFZ 136c and $162 \mathrm{~b}$ (Figure $9-\mathrm{c}$ ), is characterized by the highest recorded concentrations of total organic carbon within a wide range of fluctuations. The TOC values within this interval go as high as $18.39 \%$ at stratigraphic level PFZ-137, to as low as $0.16 \%$ at stratigraphic levels PFZ. 146 and PFZ-156 (Figure 9-ce, and Appendix 2).

The uppermost part of the La Peña Formation corresponding to the interval between stratigraphic levels PFZ-162c and PFZ-203 (correlative with microfacies subunits $\mathrm{J}$ and $\mathrm{K}$, Figures 7 and 8), is characterized by total organic carbon values predominantly below $5 \%$. Occasionally concentrations as high as $15.13 \%$ occur within this interval, such is the case at stratigraphic level PFZ-198 (Figure 9-c, and Appendix 2).

\section{LA BOCA CANYON}

Facies of the Lower Tamaulipas Formation (stratigraphic levels LB A-1 through LB A-11) are characterized by total organic carbon contents fluctuating between $1.45 \%$ at stratigraphic level LB A-1, and $4.32 \%$ at stratigraphic level LB A-8 (Figure 10-a, and Appendix 3). In general, the total organic carbon content remains much the same throughout the Lower Tamaulipas and La Peña formational contact, and farther up into the younger levels. In fact, the TOC content in strata of the lower part of the La Peña Formation (stratigraphic levels LB A-12 through LB G-7) is identical to the content in the infrajacent Lower Tamaulipas Formation (Figure 10-b, and Appendix 3). The first apparent major increase in the total organic carbon content occurs later in the La Peña Formation, as recorded in the interval between stratigraphic levels LB G-9a and LB G-25, where TOC values are $17.57 \%$ and $16.16 \%$, respectively (Figure 10-b, and Appendix 3). A drop in 
the total organic carbon content occurs in the interval between stratigraphic levels LB G-26 and LB I-60 (Figure 10-b), where the values vary between $1.43 \%$ (stratigraphic level LB I-16a) and 9.20\% (stratigraphic level LB 1-3a) (Figure 10-b, and Appendix 3). The uppermost part of the La Peña Formation corresponding to the interval between stratigraphic levels LB K-1 and LB S-6 (Figure 10-c), reveals the highest values in total organic carbon content in the strata at La Boca Canyon, with a maximum of $19.46 \%$ at stratigraphic level LB K-5 (Figure 10-c, and Appendix 3). 


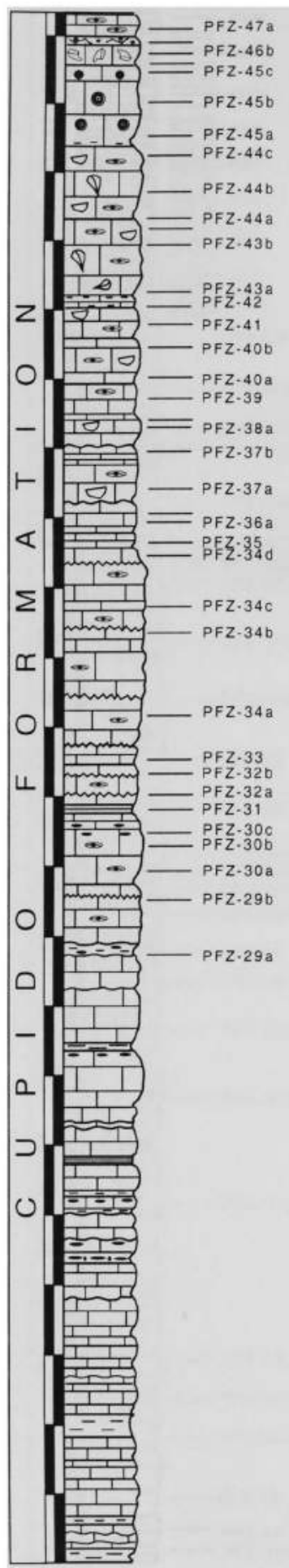

Presa Francisco

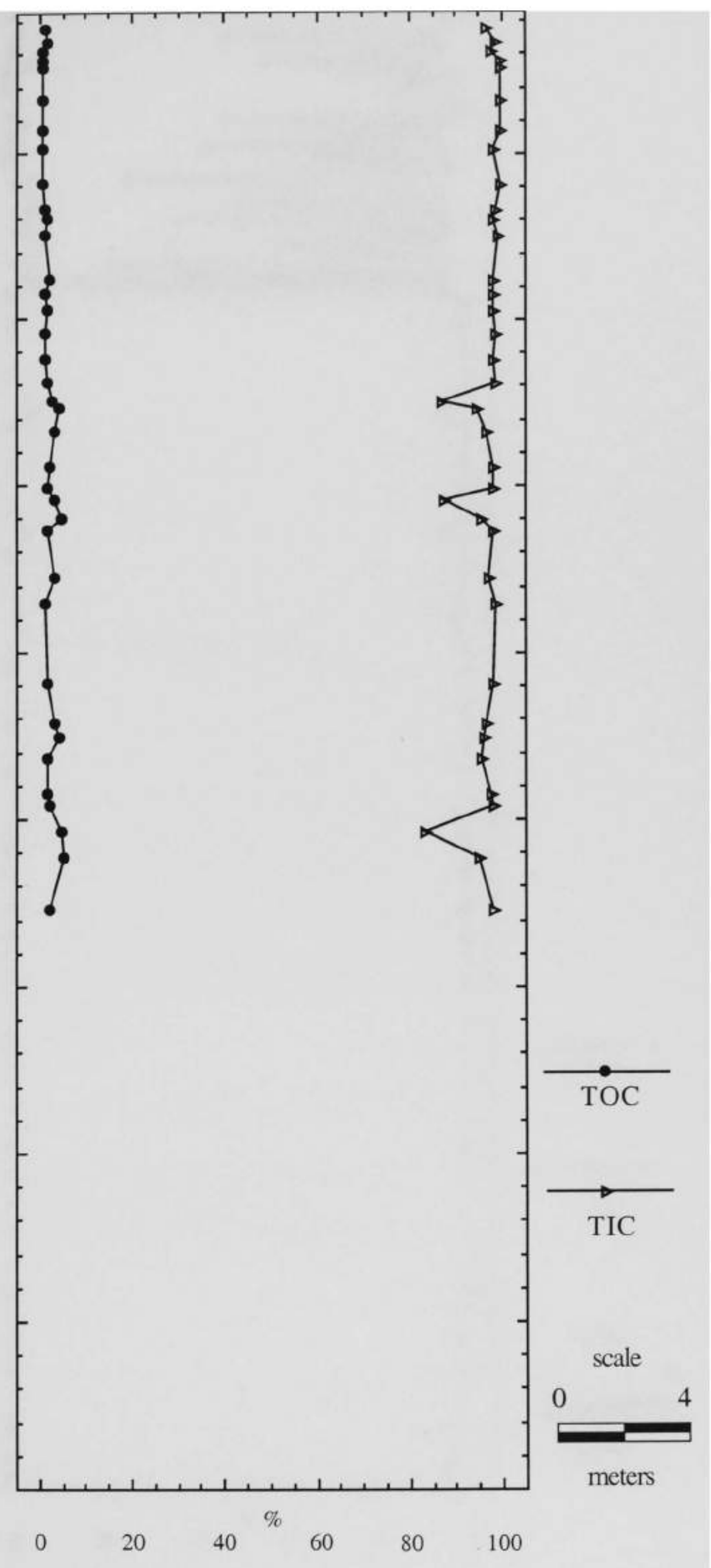

Figure 9-a. Stratigraphic column of the Presa Francisco Zarco section, displaying the vertical variations on the carbon/carbonate content (first part). 


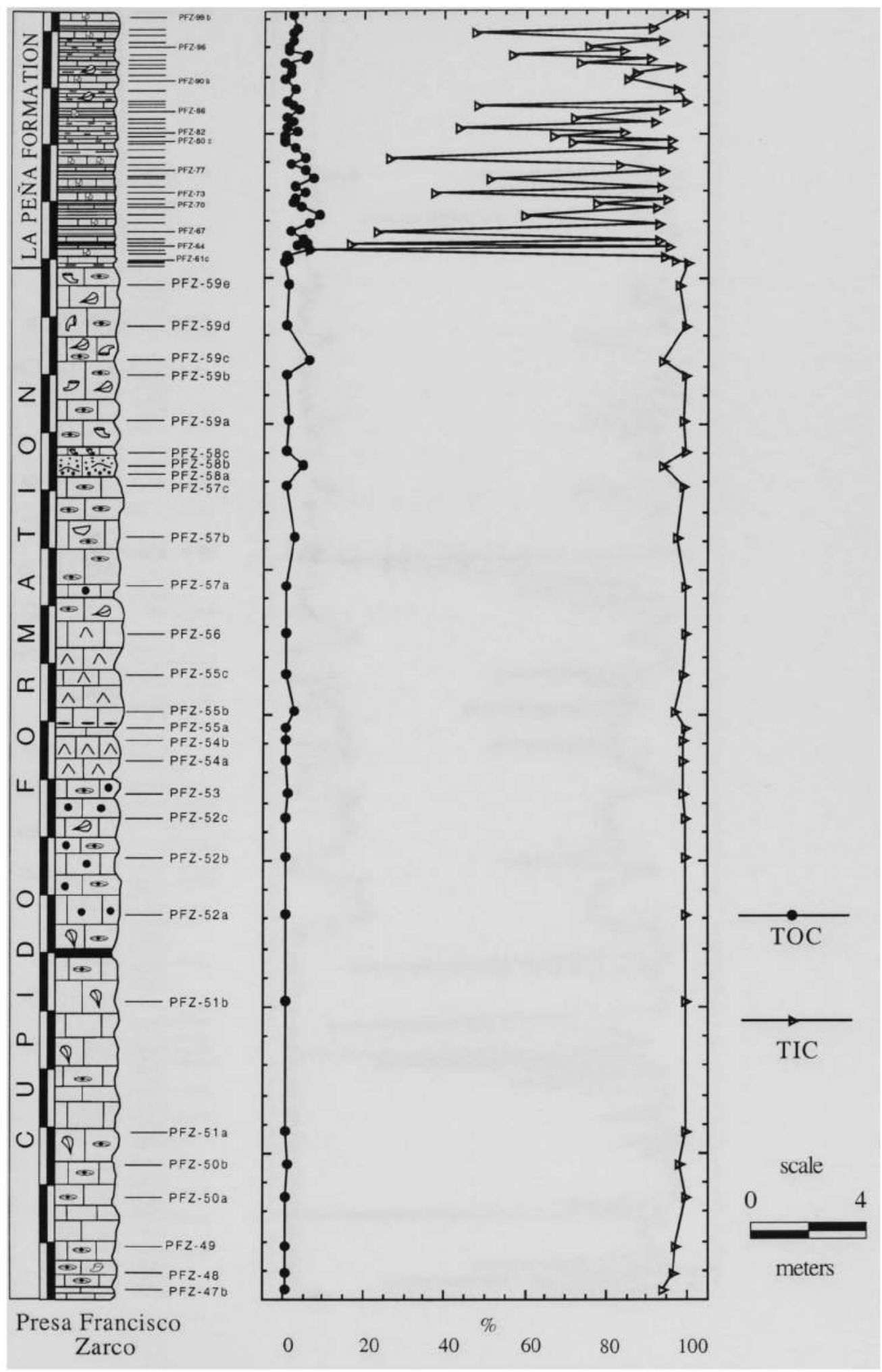

Figure 9-b. Stratigraphic column of the Presa Francisco Zarco section, displaying the vertical variations on the carbon/carbonate content (second part). 


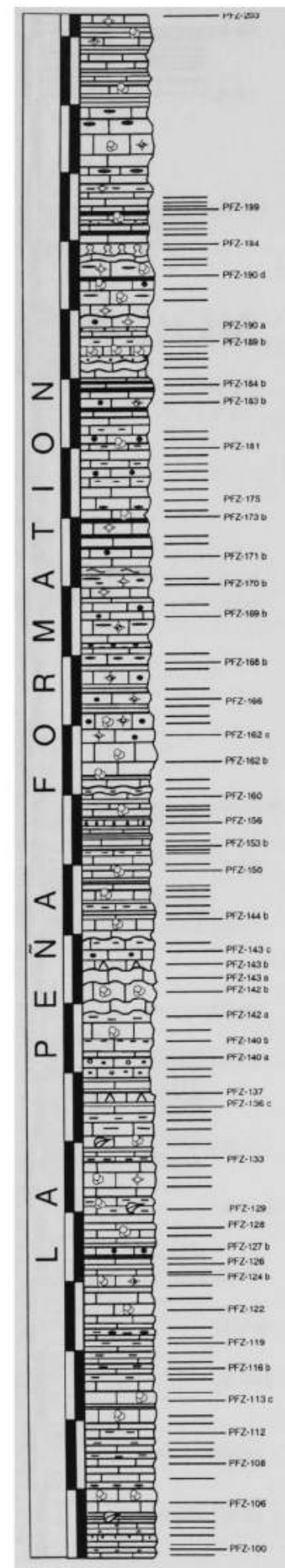

Presa Francisco

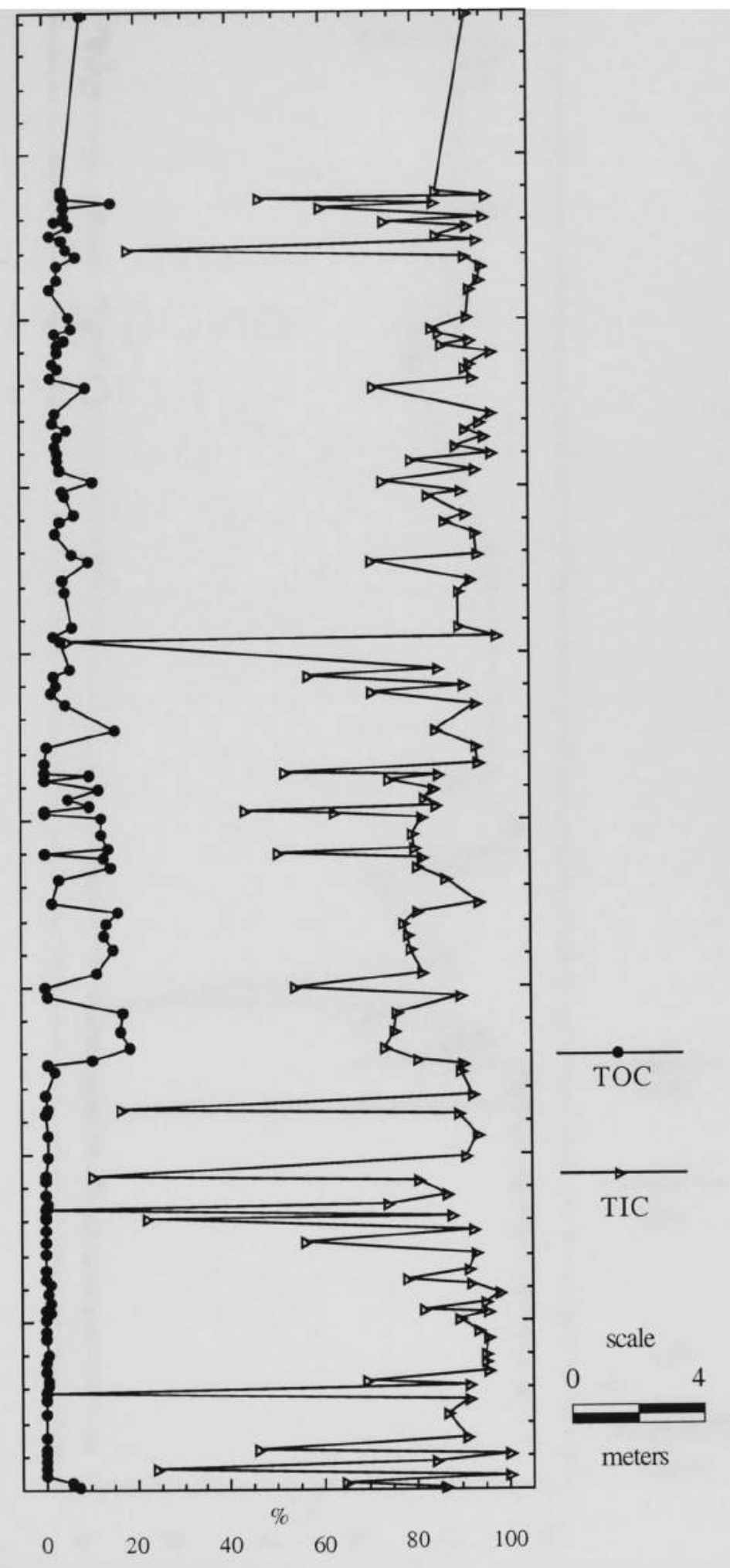

Figure 9-c. Stratigraphic column of the Presa Francisco Zarco section, displaying the vertical variations on the carbon/carbonate content (third part). 


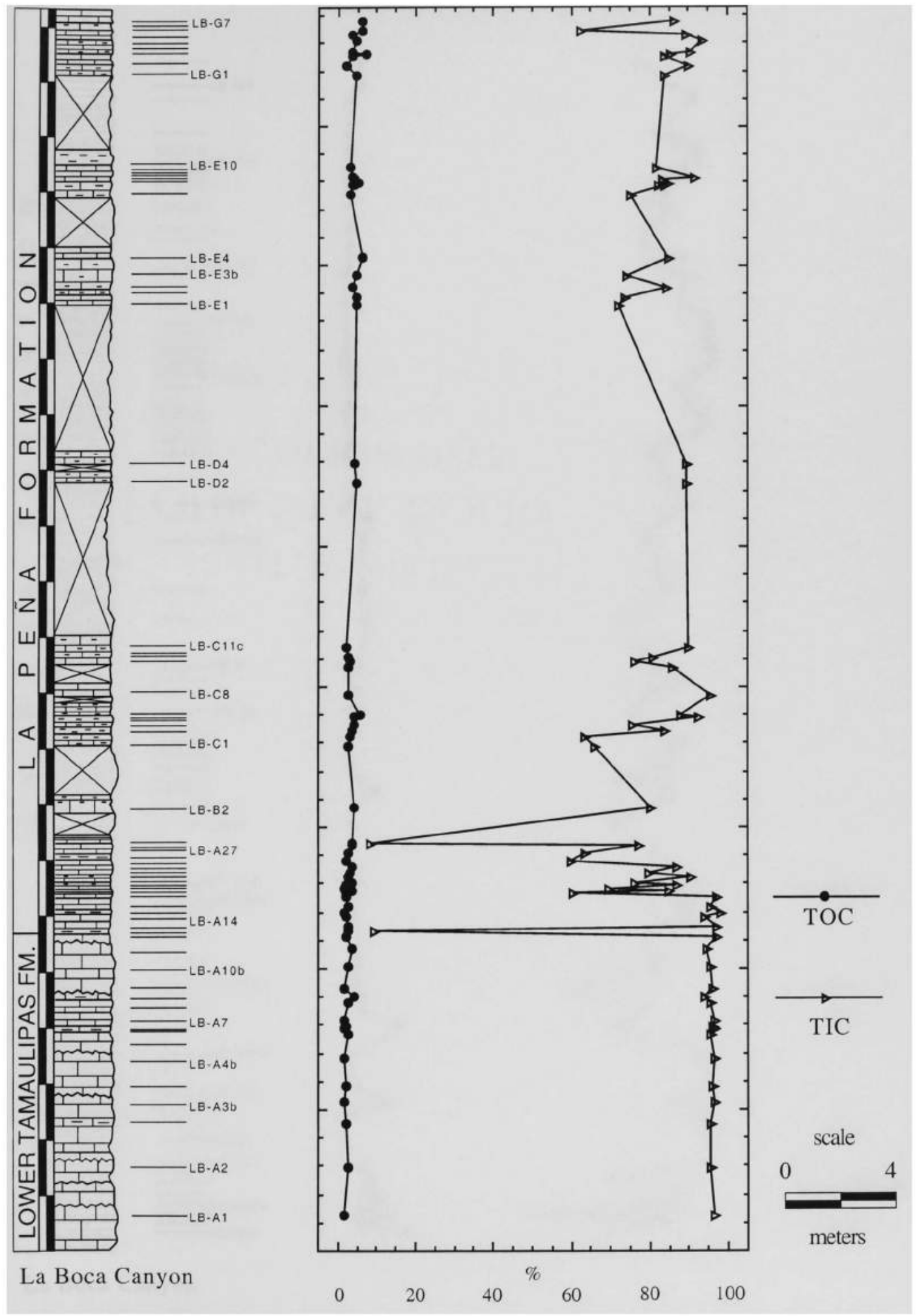

Figure 10-a. Stratigraphic column of the Presa Francisco Zarco section, displaying the vertical variations on the carbon/carbonate content (first part). 


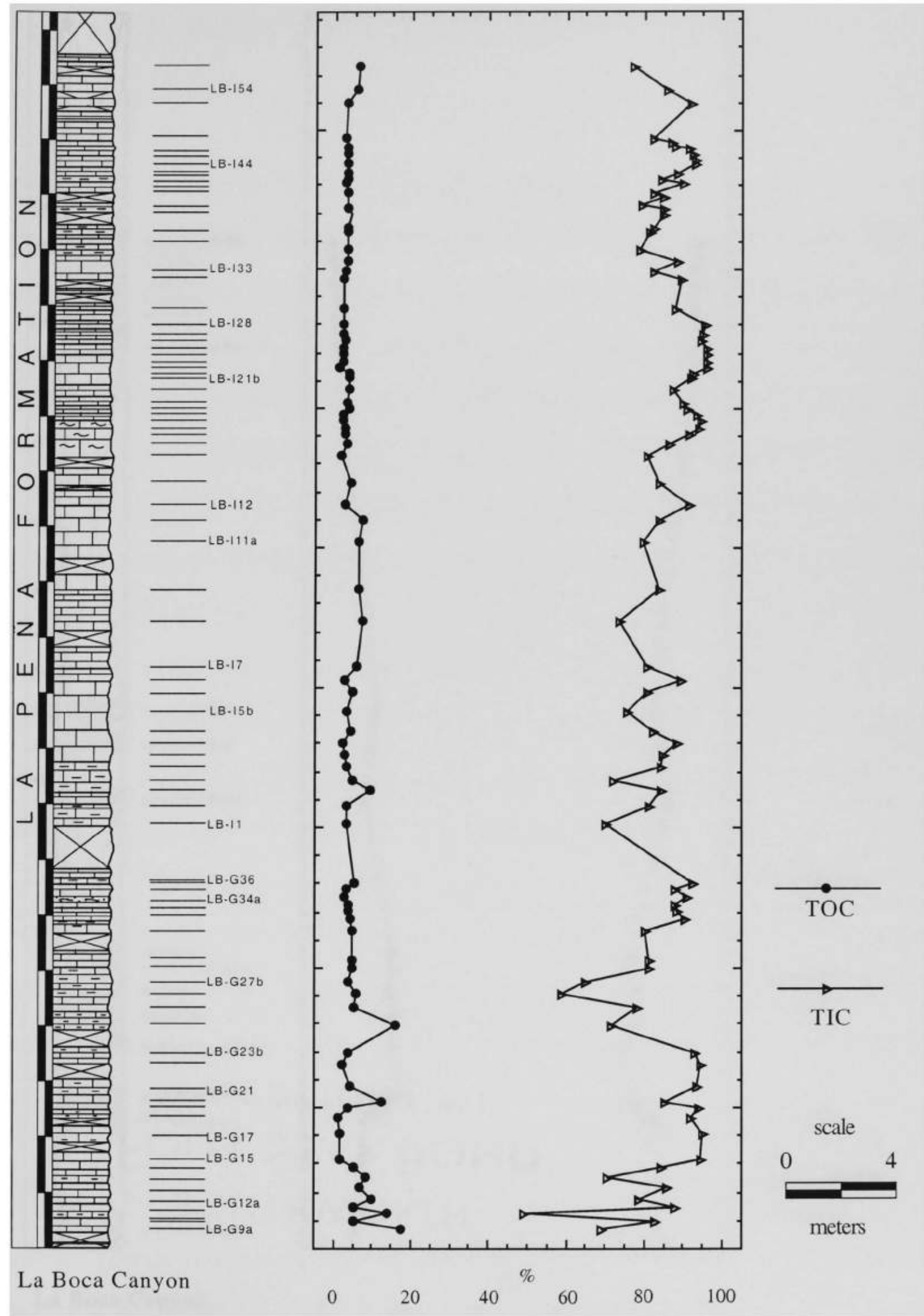

Figure 10-b. Stratigraphic column of the Presa Francisco Zarco section, displaying the vertical variations on the carbon/carbonate content (second part). 


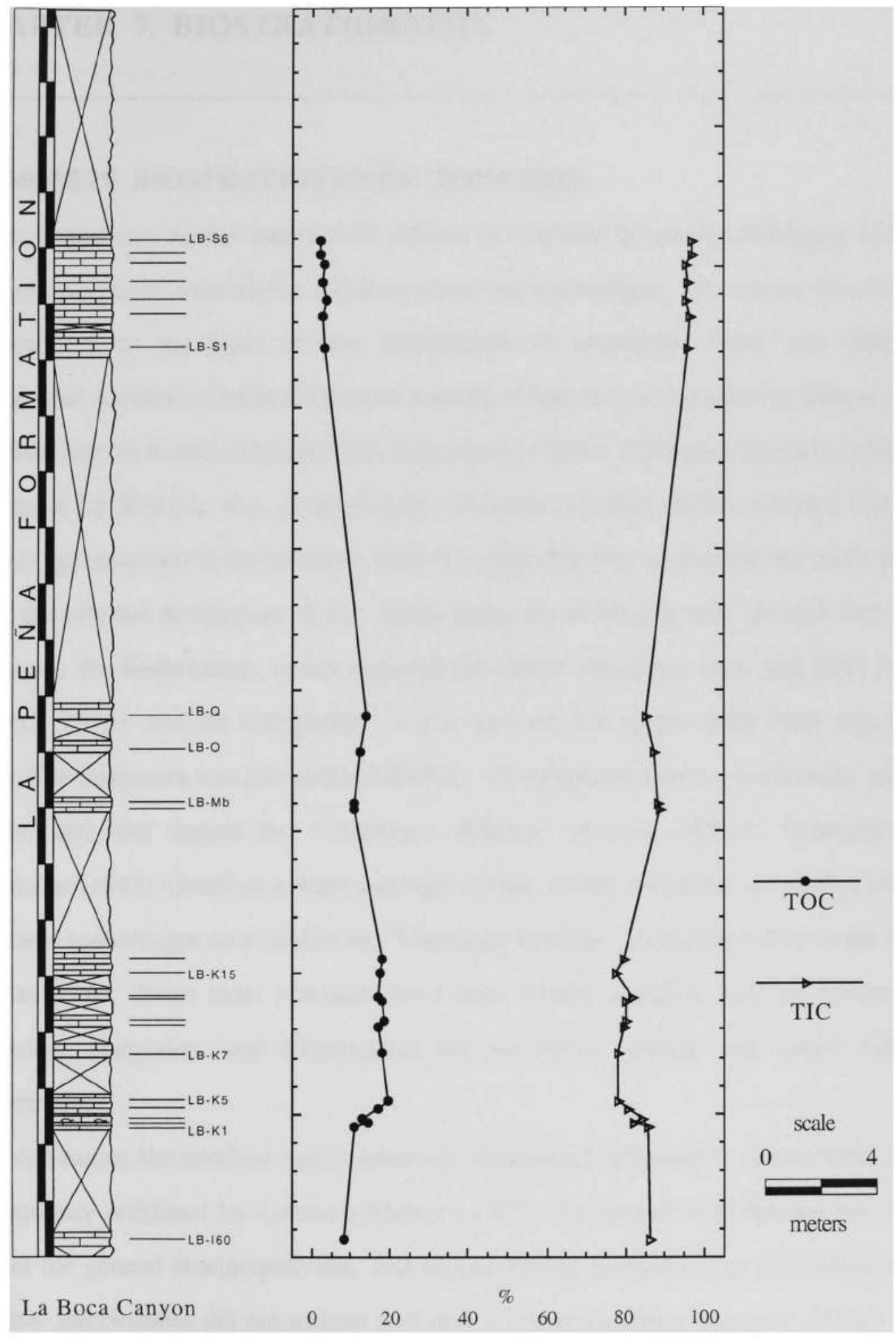

Figure 10-c. Stratigraphic column of the Presa Francisco Zarco section, displaying the vertical variations on the carbon/carbonate content (third part). 


\section{CHAPTER 7. BIOSTRATIGRAPHY}

\section{AMMONITE BIOSTRATIGRAPHIC ZONATION}

Lower Cretaceous Aptian stages were defined in southern France by d'Orbigny (1840) who also developed a correlation based on ammonite assemblages. The Aptian was further characterized on the basis of two assemblages of ammonites from two different stratigraphic sections, one identified at the locality of Apt, close to the town of Gargas, and the other near the hamlet of La Bédoule. The section at Apt is composed of marls, whereas the one at La Bédoule was predominately limestone. Further studies revealed that the assemblage contained in the limestone beds was older than the one found in the marly beds. Thus the original designation of the Aptian stage by d'Orbigny was divided into two substages: the Bedoulian, which included the lower calcareous beds and their fauna (Toucas, 1888), and the Gargasian, which enclosed the upper marly beds and their fauna. The Gargasian was also characterized by an uppermost horizon particularly rich in fossils, and was named the "Clansayes Horizon" (Kilian, 1888a). Subsequently, Breistoffer (1947) identified a third substage for the Aptian based on his studies of the ammonite assemblages contained in the "Clansayes Horizon", which he raised to the level of a substage. These three substages have been widely accepted, and are known as Bedoulian, Gargasian, and Clansayesian for the lower, middle and upper Aptian, respectively.

As stated earlier, the standard Aptian ammonite biozonation proposed by Cantu (1963), and subsequently redefined by Contreras-Montero (1977) for northeastem Mexico has been helpful for general stratigraphic use, and served worthy purposes, but difficulties arise because the biozones did not include well defined biostratigraphic horizons (FAD's and LAD's) of the nominal taxa. 
In the present study, detailed stratigraphic data on twenty three index taxa identified in the Francisco Zarco and La Boca sections, allow further tefinement of the Aptian ammonite biozonation presented by previous authors (Cantu, 1963; Contreras-Montero , 1977). This new biozonation is intended for regional use in northeastern Mexico, because of recognized endemism of the characteristic taxa of the western Tethysian realm. In addition, because of the intermittent character of the stratigraphic occurrence of the ammonite species in the sections studied, the first occurrences (FAD's) and the last occurrences (LAD's) of the taxa are here considered strictly as stratigraphic events rather than evolutionary phenomena. Thus, the absolute boundaries of the proposed biozones may be closely approximate, but they may differ from one area to another. Figure 11 (in pocket) shows temporal distribution of useful index taxa present in the La Peña Formation at Presa Francisco Zarco and its correlation to the formerly established biozones (Cantu, 1963; Contreras-Montero, 1977).

Two types of biozones are used in the construction of the following biozonal scheme:

1) Taxon-Range-Zone, and

2) Interval-Zone

The delimitation of the biozones and the assignment of their names were made in compliance with the recommendations of the International Subcommission on Stratigraphic Classification (Hedberg, 1976), and the North American Stratigraphic Code (AAPG, May 1983).

The formerly established ammonite biozonal scheme for northeastern Mexico (Cantu, 1963; Contreras-Montero, 1977), was based on the presence of index taxa from the La Peña Formation, and include three zones or informal units from oldest to youngest as follows:

1) "Unidad con Dufrenoyia justinae"

2) "Unidad con Caseyella reesidei (currently known as Pseudohaploceras reesidei) and Rhytidohoplites robertsi", and 
3) "Unidad con Hypacanthohoplites gr, jacobi and Acanthohoplites s.s." (ContrerasMontero, 1977, correlation chart).

Four ammonite biozones were identified in this work (Figure 11, in pocket). Their description and boundaries are described from oldest to youngest as follows:

\section{Dufrenoyia justinae Taxon-Range-Zone}

Definition: The base of the Dufrenoyia justinae Zone is defined by the first appearance (FAD) of the nominate taxon at stratigraphic level PFZ-61, less than 50 centimeters above the onset of the La Peña Formation facies (Figures 5, and 11, in pocket). The zone is essentially characterized by the full range of occurrence of Dufrenoyia justinae, with its last appearance (LAD) placed at stratigraphic level PFZ-101 (Figures 5, and 11, in pocket).

This zone also includes the full range of $D$. bösei and $D$. durangensis, and the partial concurrent occurrence of $D$. dufrenoyi and $D$. scotti, which extend into the lower part of the suprajacent zone. The upper part of the Dufrenoyia justinae Zone can also be distinguished by the presence of Colombiceras spathi and Paracymatoceras milleri, which are found only at stratigraphic level PFZ.93 (Figures 5, and 11, in pocket).

The top of the zone is coincident with the base of the Burckhardtites nazasensis/Rhytidoplites robertsi Zone (Figure 11, in pocket).

Correlation: The Dufrenoyia justinae Zone described in the present work can be correlated with the Dufrenoyia justinae Zone described by Cantu (1963) and Contreras-Montero (1977), however, these authors subdivided the Aptian stage in northeastern Mexico into lower and upper substages, with the Dufrenoyia justinae Zone being placed at the base of the upper Aptian. The present assignment of the Dufrenoyia justinae Zone to the uppermost ammonite zone of the lower Aptian (Figure 11, in pocket) is based on correlation with the Dufrenoyia furcata Zone of the Mediterranean region which has been 
assigned to the uppermost part of the lower Aptian by the team of the International Geologic Correlation Program 262: Tethyan Cretaceous Correlation (Hoedemaeker et al, 1993). This new stratigraphic consensus also adopted a subdivision of the Aptian into lower, middle, and upper, which is used in the present work.

\section{Burckhardtites nazasensis/Rhytidoplites robertsi Interval-Zone}

Definition: The Burckhardtites nazasensis/Rhytidoplites robertsi Zone is defined by the combined ranges of the characterizing nominate taxa (Figure 11, in pocket). The base of the zone is delimited by the first appearance (FAD) of Burckhardtites nazasensis at stratigraphic level PFZ-101, and successively at levels 104, and 106, respectively (Figure 11, in pocket). The upper part of the zone is distinguished by the full range of Rhytidoplites robertsi which is first recorded at stratigraphic level 108, and then in the suprajacent strata 110,112,113, and 122, respectively (Figure 11, in pocket).

The Burckhardtites nazasensis/Rhytidoplites robertsi Zone is also characterized by a rich assemblage of ammonite species, showing the highest diversity in the Presa Francisco Zarco section. The lower boundary placed at stratigraphic level 101 (Figure 11, in pocket) also includes the last stratigraphic occurrence (LAD's) of Dufrenoyia dufrenoyi and Dufrenoyia scotti. Its basal part (stratigraphic levels 101, 104 and 106, respectively) contains the total stratigraphic range of the only species of Burckhardtites identified in this work, namely $B$. nazasensis (Figure 11 , in pocket). In addition, the middle part of the zone is marked by the punctual occurrences of Acanthohoplites potreritensis at stratigraphic level 110, as well as Peltocrioceras (?) sp, Acrioceras (Epacrioceras) (?) sp., and $\mathrm{cf}$. Kazanskyella arizonica, at stratigraphic level 112 which shows the highest diversity recorded in the section. The zone comprises the first appearances and partial ranges of Cheloniceras fossae, Acanthohoplites acutecosta, Acanthohoplites aschiltaensis (all starting at stratigraphic level 108), as well as Parahoplites mexicanus (starting at stratigraphic level 
109) (Figure 11, in pocket). The complete stratigraphic range of Penaceras nursiradiatus is also contained in this zone.

The upper boundary of the Burckhardtites nazasensis/Rhytidoplites robertsi Zone taken at stratigraphic level 122 (Figure 11, in pocket) is defined by the last appearance (LAD) of Rhytidoplites robertsi, which coincides with the first stratigraphic occurrences (FAD's) of Cheloniceras fossae and Acanthohoplites aschiltaensis.

Correlation: The Burckhardites nazasensis/Rhytidoplites robertsi Zone correlates with the informal zone named "Unidad con Rhytidoplites" by Contreras-Montero (1977), which was recognized in the La Peña Formation of northeastern Mexico. This author placed the Rhytidoplites unit, together with another unit containing Pseudolaploceras reesidei, in the middle of the upper Aptian. However, Contreras-Montero (1977) also correlated the Rhytidoplites unit with the Parahoplies nutfieldiensis zone described Spath (1923) for the Aptian of England, which in turn is coeval with the Cheloniceras (Epicheloniceras) subnodosocostatum zone characteristic of the basal part of the middle Aptian as argued by Casey (1961) and Hoedemaeker et al. (1993). Since the characteristic ammonites of the infrajacent Dufrenoyia justinae Zone are certainly lower Aptian, and the taxa of the subsequent zone are by all indications upper Aptian, it is therefore suggested here that the Burckhardites nazasensis/Rhytidoplites robertsi Zone may represent the entire span of the middle Aptian in northeastern Mexico (Figure 11, in pocket).

\section{Cheloniceras inconstans Taxon-Range-Zone}

Definition: The lower boundary of the Cheloniceras inconstans Zone is defined by the first appearance (FAD) of the nominate taxon, which is at stratigraphic level 122 in the Francisco Zarco section. As stated previously, stratigraphic level 122 also includes the first appearance of Cheloniceras fossae, and the last occurrence of Rhytidoplites robertsi, the 
index species for the upper part of the preceding zone. The lowermost part of the zone encloses the last appearance of Acanthoplites acutecosta at stratigraphic level 125.

This biozone is characterized by the full range of the nominate taxon, concurrently with Cheloniceras fossae (Figure 11, in pocket). The Cheloniceras inconstans Zone is further characterized by the presence of three species of the genus Pseudohaploceras identified in this work, namely $P$. aguilerae and $P$.jacobi, and $P$. reesidei. The first two occur only in the middle of the zone at stratigraphic levels 129,132 and 134, respectively, whereas $P$. reesidei continues into the lower part of the overlying zone. As shown in figure 11, this biozone is also characterized by having the upper part of the stratigraphic ranges of Acanthohoplites aschiltaensis, and Parahophites mexicanus.

The top of the zone coincides with the last appearances (LAD) of Cheloniceras inconstans and Cheloniceras fossae at stratigraphic level PFZ-140b (Figures 5, and 11, in pocket).

Correlation: Species of the genus Acanthohoplites are normally assigned to biozones characteristic of the basal part of the upper Aptian (Hoedemaeker et al., 1993), and this is adopted in the present work where the stratigraphic position of species of this genus relative to the temporal distribution of the other taxa is compatible with them being placed in the lowermost part of the upper Aptian (Figure 11, in pocket).

\section{Hypacanthoplites ef. leanzae Taxon-Range-Zone}

Definition: The base of the Hypacanthoplites cf. leanzae Zone is distinguished by the first appearance (FAD) of the nominate species at stratigraphic level PFZ-140b (Figures 5, and 11, in pocket). As indicated for the infrajacent zone, the lower boundary taken at stratigraphic level $140 b$ also coincides with the last appearances of Cheloniceras inconstans and Cheloniceras fossae. The basal part of this biozone is also characterized by having the last stratigraphic occurrence of Pseudohaploceras reesidei, at level $142 \mathrm{~b}$. This zone is 
rather poor in ammonites, as it contains mostly one species throughout. The top of the zone is designated to coincide with the last appearance (LAD) of Hypacanthoplites cf. leanzae, which is at stratigraphic level PFZ $190 \mathrm{~d}$ (Figure 11 , in pocket).

Correlation: Species of the genus Hypacanthoplites are characteristic of the uppermost part of the upper Aptian (Hoedemaeker et al., 1993). This biozone is correlative with the Hypacanthoplites jacobi zone characteristic of the uppermost part of the upper Aptian of England (Casey, 1961) and the Mediterranean region (Hoedemaeker et al., 1993). The Hypacanthoplites cf. leanzae Zone is equivalent to the informal unit "Unidad con Hypacanthohoplites gr. jacobi and Acanthohoplites s.s." defined by Contreras-Montero (1977) for the La Peña Formation of northeastern Mexico (Figure 11, in pocket). Hypacanthoplites jacobi was not found in the study areas, and therefore has not been considered in the construction of the biozonation of this work. However, correlation of Hypacanthoplites cf. leanzae Zone of this work, with the unit previously defined by Contreras-Montero (1977) for the Aptian of northeastern Mexico, was based in the apparent coeval ranges of both species of the genus Hypacanthohoplites that define both biozones in northeastern Mexico.

The uppermost part of the La Peña Formation, above the Iypacanthoplites cf. leanzae Zone at Francisco Zarco, is apparently late late Aptian-early Albian in age, as can be attested by the record of the tintinids of microfacies subunit $\mathrm{K}$ (Figure 11 , in pocket, Plate 35, Figs. 3 , 6-7), and the planktonic foraminifer Ticinella sp. (Plate 35, Figs. 4-5).

The record of index ammonite species such as, Pseudohaploceras reesidei (Humphrey), Dufrenoyia justinae (Hill), Acanthohoplites aschiltaensis (Anthula), Colombiceras spathi Humphrey, Penaceras nursiradiatus (Humphrey), Rhytidoplites robertsi Scott, and 
Parahoplites mexicanus Humphrey, within the stratigraphic sequence at La Boca Canyon, suggests that there is a record of the four ammonite zones established for the Francisco Zarco section at that locality. 


\section{CHAPTER 8. SYSTEMATIC AMMONITE PALEONTOLOGY}

In the present work, the ammonite taxonomy used to identify taxa to the genus level is after Wright, et al. (1996), whereas subsequent identification of species within genera used mostly the works of d'Orbigny (1840-1842), Kilian (1888b), Hill (1893), Anthula (18991900), Burckhardt (1925), Riedel (1938), Scott (1940 a), Humphrey (1949), Stoyanow (1949), Cantu (1963), Cantu (1976), and Contreras-Montero (1977).

Genera within families and species within genera are described by alphabetical order. The type species of the nominal genus is placed immediately after the name of each genus. Numbers in parentheses after each species name refer to the identification number of the corresponding figure within the plates that illustrate the materials used in this work.

The synonymy list includes the original description of a taxon, and subsequent available works in which the corresponding species is properly identified and illustrated. The description of each species consists of the general original morphological characterization of the shell, as observed by the author, but with modifications or emendations when indicated. Dimensions of the four measurable parameters of the shell are expressed in $\mathrm{mm}$ as shown in Figure 13, which is a synopsis of characters obtained from representative specimens of each taxon illustrated in the present work. Species descriptions are complemented with measured values of the morphological characters observed, whenever possible. Not all specimens lent themselves to easy measurement, because of their state of preservation, as indicated by the appropriate blank space.

The discussion of the remarks emphasize the morphological features that define each species, by comparing characteristics that make them different from other species within the same genus. A brief discussion is also given here in regard to similarities and differences between specimens studied within a given assemblage, and those found at other sites elsewhere in Mexico, as well as any other geographic locations where that particular 
species has been reported. Paleoecologic and sedimentologic characteristics of the rocks from which each species was sampled are also stressed in the remarks in order to have a better understanding of the relationships between the fossil assemblages and their paleoenvironments.

Finally, a brief comment on the geographic occurrence of each species is given in order to understand their spatial distribution, which may provide clues to the possible controlling factors related to the paleogeography and paleoceanography of that time.

\section{REVIEW OF THE MORPHOLOGICAL TERMS APPLIED TO THE SHELLS OF AMMONITES}

The Order Ammonoidea (Zittel, 1884) of the Class Cephalopoda (Leach, 1817) includes a group of mollusks that appeared in the Early Devonian and became extinct at the end of the Cretaceous. Ammonites have been used as excellent biomarkers useful for biostratigraphic and biochronological analyses because they were very abundant, had worldwide geographic distribution, and often had short stratigraphic ranges or index species. Our knowledge of the morphology of the ammonites is confined almost entirely to their fossil shells, and inferences from studies of their close living analog of the genus Nautilus, a presumed relative of the group. The mineral content of the shell was essentially aragonitic.

The typical ammonite shell is univalve, coiled, normally planispiral, but may also show a variety of other coiling directions, or may be nearly straight The external surface of the shell may be smooth or marked by a variety of ornaments primarily consisting of a series of ribs, bullae, tubercles, flanges, and spines. The terms concave and convex will be used for sinuous patterns of elongated omaments that develop along the sides or flanks of the shell, which will be oriented relative to the aperture, being concave when hollow faces the apertural direction, and convex when hollow faces the internal whorls. 
As can be seen in Figure 12, the typical ammonoid shell is tightly coiled in a spiral plane, and each coil or volution of the shell is called a whonl. Most shells consist of several whorls that are in contact, and which can be divided into three main sections: a) the protoconch or initial chamber, which represents the embryonic stage of the animal; b) the phragmocone, which comprises the bulk of the ammonoid shell and shows a characteristic chambered appearance because of the presence of regularly spaced walls called septa; and c) the living chamber, a single large terminal body cavity, which may be closed by a separate, simple or compound operculum called the aptychus All three parts are interconnected inside the chambers by a narrow, continuous siphuncle, or longitudinal tube which is located at the periphery of the shell and passes through all chambers and ends at the base of the living chamber. The concave surface on each side enclosed by the last whorl (Figure 13) is called the umbilicus, and the coiling is said to be evolute or involute according to whether the umbilicus is wide or narrow. Some forms are not tightly colled at the center, and there is an umbilical perforation; others begin to uncoil with the last whorl.

These, and other more aberrant forms, are known as heteromorphs which are ammonoids displaying shells of any form except in a spiral plane with whorls in contact.

Regardless of shell orientation in traditional illustrations, which show the aperture upward, the conventional terms ventral and dorsal are used on ammonoids, based on the assumption that in normally coiled forms, the animal was oriented as in a living Nautilus. Thus, in accordance with this convention of the shell orientation, the dorsum is toward the center of the coil, the venter is outward, therefore the periphery of the shell is the venter and the opposite side is the dorsum. Furthermore, the shell can be differentiated longitudinally in two halves: 1) the anterior half, if it contains the aperture, and 2) the posterior half, if it contains the protoconch of the ammonite. Thus, in describing features of the shell, those which are nearer or directed towards the aperture are called anterior, whereas those which are nearer or directed towards the protoconch, are said to be posterior. Each side or flank of 
the shell can be further differentiated in two halves, depending on their position relative to the venter or the dorsum. The half portion close to the venter is said to be external, whereas the other half close to the dorsum is said to be internal (Figure 12).

As explained above, if it is assumed that ammonites shell in life position were similar to the present living Nautilus, the aperture of the ammonoids must normally have been situated at the underside (Figure 12). However, as shown in Figure 13, conventional descriptions and illustrations of ammonoids are oriented with the aperture upward, and all the described features of the shell follow that orientation (Arkell et al., 1957; Wright et al., 1996). 


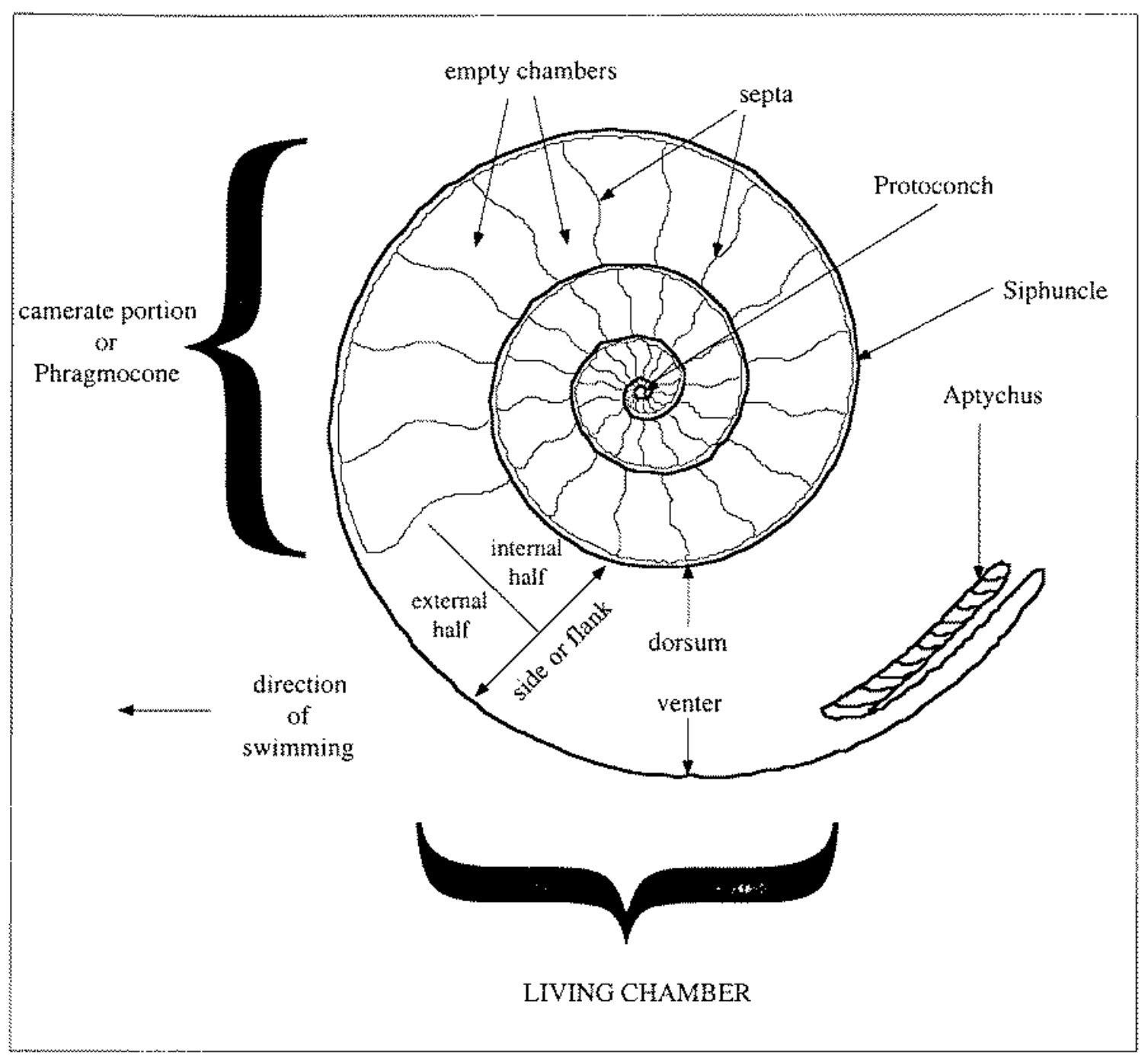

Figure 12. Sketch of the three main sections of an ammonoid shell. Orientation is shown as in living position, which is assumed to be analog with modern living Nautilus. 


\section{FRONTAL VIEW}

\section{LATERAL VIEW}

last whorl height

whorl

section
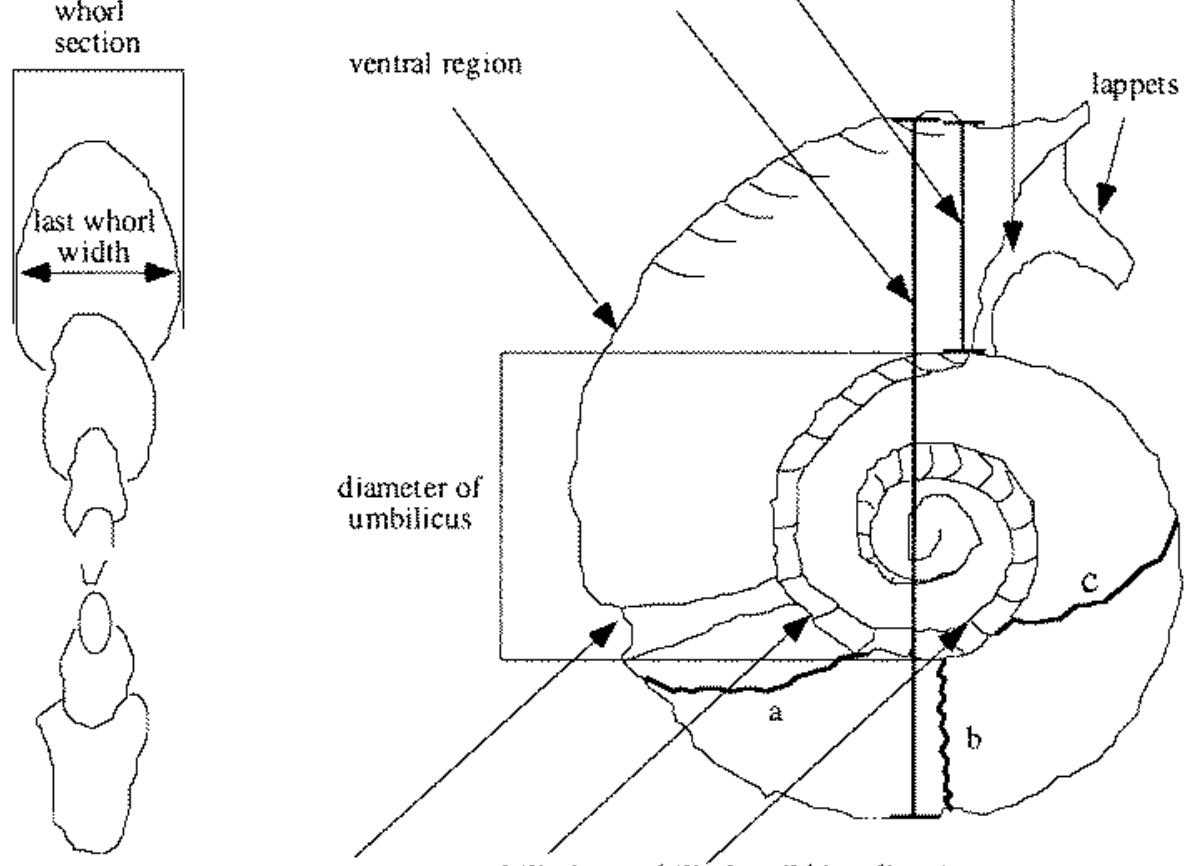

constriction

umbilical umbilical ribbing direction:

a) prorsiradiate (projected anterionly)

b) rectiradiale (projected radially)

measurable parameters: * total diameter

c) nutsiradiate (projected posteriorly)

* last whorl height

* last whorl width

* diameter of umbilicus

Figure 13. Sketch of an ammonite showing the morphological features used in the description of the shells, including the measurable parameters shown with asterisks. Orientation of shell is not in living position. 


\section{Phyllum Mollusca}

\section{Class Cephalopoda Leach, 1817}

Order Nautiloidea

Family Cymatoceratidae Spath, 1927

\section{Genus Paracymatoceras Spath, 1927}

Type species. Nautilus asper Oppel, in Zittel, 1868, Plate III, Fig. 1.

Paracymatoceras milleri Humphrey, 1949

(Plates 47 and 48)

Paracymatoceras milleri Humphrey, 1949, p. 119, Plate 4, Fig. 1; Plate 5, Figs. 1-2.

\section{Description:}

The following description is modified after Humphrey:

Shell involute, discoidal, compressed. Whorl section much higher than wide; subtrapezoidal in outline; thickest in third portion of flank closer to dorsum. Flanks flattened; venter narrowly rounded in intemal whorls, flattened convex toward apertural zone of outer whorl. Umbilicus small, less than one-sixth greatest diameter of conch; umbilical shoulder rounded; umbilical wall inclined.

Surface of shell marked by prominent transverse ribs that begin on umbilical wall and are almost straight across two-thirds of flanks in dorsum region, curving sharply posteriorly on third portion of lateral zones of ventrum, to form deep, narrowly rounded ventral sinus. Some ribs split into two equal branches just below middle of flanks.

Holotype dimensions:

Total diameter: $127 \mathrm{~mm}$, Last whorl height: $70 \mathrm{~mm}$, Last whorl width: $47 \mathrm{~mm}$, Diameter of umbilicus: $20 \pm \mathrm{mm}$ 
Only one specimen of Paracymatoceras milleri was found at level 93 of the Francisco Zarco section, and it shows the following dimensions:

$\begin{array}{llcrl} & \begin{array}{c}\text { Total } \\ \text { diameter }\end{array} & \begin{array}{c}\text { Last whorl } \\ \text { height }\end{array} & \begin{array}{c}\text { Last whorl } \\ \text { width }\end{array} & \begin{array}{c}\text { Diameter } \\ \text { of umbilicus }\end{array} \\ \text { Specimen PFZ.0273 } & 203 \mathrm{~mm} & 101.12 \mathrm{~mm} & 66.28 \mathrm{~mm} & 20 \pm \mathrm{mm}\end{array}$

Remarks:

Assignment of the specimen found at Presa Francisco Zarco to Paracymatoceras milleri is based on Humphrey's work from Sierra de Mapimi, in the State of Durango, Mexico. The species was described by Humphrey (1949, p. 119) from his study of a complete, and well preserved specimen, which was also reported to be a somewhat compressed. This taxon is very similar to Paracymatoceras texanum (Shumard) from the Washita Formation of Texas, but as observed by Humphrey, $P$. milleri has a narrower umbilical region, and a less inflated whorl section. Perhaps the slight differences observed between $P$. milleri and $P$, texanum, could have been related to ecophenotypic variations not yet recognized. However, the illustration of the specimen of $P$. milleri by Humphrey compared to the specimen of $P$. texanum illustrated by Miler and Harris (1945, pl. V, fig. 2), clearly shows that the two species can be further recognized by the difference in their ventral region, which is more broadly rounded in $P$. milleri than in $P$.texanum.

Paracymatoceras milleri is the only species of the Order Nautiloidea found in the stratigraphic sections studied. The occurrence of $P$. milleri at stratigraphic level 93 of the Francisco Zarco section (Fig. 11, in pocket) is associated with all five species of the genus Dufrenoyia identified in the present work, as well as with Colombiceras spathi Humphrey. Level 93 falls within the lower Aptian Dufrenoyia justinae Zone (Figure 11 , in pocket), and corresponds to a planktonic foraminiferal and echinoid-rich black biocalcilutite in which non-carbonate terrigenous components are common. Level 93 is within the lower part of 
the La Peña Formation which, along with levels $67,71,73,75$, and 85 , is also one of the richest levels in ammonites. These stratigraphic levels belong in the lower part of microfacies zone 1 of the La Peña Formation (Figure 7), and they have organic carbon contents between 3 and $6 \%$ (Figure 9-b).

\section{Occurrence:}

Paracymatoceras milleri has been found only from the La Peña Formation in Mexico, and has been reported at Puerto de San Isidro, Sierra de Mapimí (Humphrey, 1949), and at the section at Presa Francisco Zarco, Sierra del Rosario, in Durango State (this work), of Northeast Mexico. Its limited occurrence in Mexico suggests that it may be an endemic species of that area.

Order Ammonoidea Zittel, 1884

Suborder Ammonitina Hyatt, 1889

Superfamily Desmocerataceae Zittel, 1895

Family Desmoceratidae Zittel, 1895

Subfamily Puzosinae Spath, 1922

\section{Genus Pseudohaploceras Hyatt, 1900}

Type species. Ammonites liptoviensis Zeuschner, 1856, p. 181 (cited by Uhlig, 1883, p.229, Plate XVII, Figs. 9, 16-18, Plate XVIII, Figs. 1, 3, 5-6). 
Pseudohaploceras aguilerae (Burckhardt, 1925)

(Plate 49, Figs. 1-4)

Uhligella Aguilerae Burckhardt, 1925, pp. 10-11, Plate 2, Figs. 4-6.

Pseudohaploceras aguilerae (Burckhardt, 1925): Wright et al., 1996, p. 73.

\section{Description:}

The following description is emended from the original description given by Burckhardt in Spanish:

Shell discoidal and moderately involute, with last whorls embracing about half of preceding whorls. Umbilicus narrow but broadens with age. Flanks slightly convex or flat. Whorl section elongate, much higher than wide, with the greatest thickness in the middle of the flanks.

The ornamentation on the posterior part of the outer whorl consists of quite prominent and separated flexuous flanges ("bourrelets") which originate in the umbilical border. They are arched toward the protoconch in the half of the flanks closer to dorsum, and then arched toward the aperture in the half of the flanks closer to venter, crossing the ventral region with a convexity directed toward the apertural zone. Discrete grooves are adjacent to the flanges, and two ribs that originate about the middle of the flanks are intercalated in the interspaces between flanges. These intercalated ribs are much finer than the flanges and, like them, they cross the venter with a convexity directed anteriorly.

The part of the outer whorl closer to the aperture encloses an ornamentation that is similar to that of the part closer to the protoconch, where the flanges are less separated and look like strong ribs. Also, the part of the outer whorl that is closer to the protoconch has intercalated ribs between the flanges, and they originate either in the middle of the flanks, or in the umbilical border. The following are the dimensions of the holotype: 
Total diameter: $40 \mathrm{~mm}$, Last whorl height: $17 \mathrm{~mm}$, Last whorl width: $14.5 \mathrm{~mm}$, Diameter of umbilicus: $14 \mathrm{~mm}$.

Dimensions of representative specimens of Pseudohaploceras aguilerae from Presa Francisco Zarco

\begin{tabular}{|c|}
\hline $\begin{array}{l}\text { Total } \\
\text { diameter }\end{array}$ \\
\hline
\end{tabular}

Specimen PFZ-0298a

$13.85 \mathrm{~mm}$

$14 \mathrm{~mm}$

Specimen PFZ $0298 b$

$28 \mathrm{~mm}$

$11.71 \mathrm{~mm}$

$10 \mathrm{~mm}$

Specimen PFZ-0303

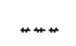

$13.09 \mathrm{~mm}$

Specimen PFZ-0308

$\quad 8.64 \mathrm{~mm}$

\section{Remarks:}

Pseudohaploceras aguilerae was proposed by Burckhardt (1925) based on specimens collected from the Nazas River area in Durango State, northeastern Mexico. Although it was originally described as a species of the genus Uhligella, this taxon is now placed in the genus Pseudohaploceras. As discussed by Spath (1923, pp. 31-39), the superficial resemblance between all of the various genera that comprise the family Desmoceratidae has often led to misidentification of the different genera.. However, Pseudohaploceras can be clearly distinguished by the prominence of its flanges along the flanks, which are almost absent in Uhligella giving a smooth appearance to the shell of this genus. Pseudohaploceras aguilerae (Burckhardt) resembles Pseudohaploceras reesidei (Humphrey), but can be easily recognized from it by its more depressed flanges and wider spaces between them.

Four specimens found at stratigraphic levels 129 and 132, within the upper Aptian Cheloniceras inconstans Zone of the La Peña Formation at Francisco Zarco section (Figure 11, in pocket) were assigned to this species. All the specimens are morphologically similar to those identified as Uhligella Aguilerae by Burckhardt (1925). At the Francisco Zarco 
section $P$. aguilerae is in association with two other species of $P$ seudohaploceras identified in the present work, namely $P$. jacobi and $P$. reesidei, as well as with specimens of Acanthoplites aschiltaensis (Anthula), Parahoplites mexicanus Humphrey, Cheloniceras fossae Humphrey, Gargasiceras (Gargasiceras) gargasence (d'Orbigny), and Mathoceras sp. It should be noted that one of the two stratigraphic levels containing Pseudohaploceras aguilerae in the above assemblage (PFZ-129), is also characterized by having less total calcium carbonate than the adjacent beds (Appendix 2), although their total organic carbon content is less than $1 \%$ (Figure 9-c). These levels correspond to marly limestones, and are coincidental with the middle part of microfacies zone I characterized by abundant planktonic foraminifera (Figures 7 and 8 ).

\section{Occurrence:}

Pseudohaploceras aguilerce has only been reported from the La Peña Formation at Loma Verde from the Nazas River area (Burckhardt, 1925), and at Presa Francisco Zarco (this work), both located in Durango State, Northeastern Mexico. There is not apparent significant differences between the forms reported from both localities. Given the limited occurrence of this taxon, it can be considered as an endemic species for this area of study.

Pseudohaploceras jacobi (Burckhardt, 1925)

(Plate 49, Figs. 5-11)

Uhligella Jacobi Burckhardt, 1925, pp. 11-12, Plate 2, Figs. 7-10.

Uhligella Jacobi Burckhardt, 1925: Humphrey, 1949, pp. 154-155, Plate 18, Figs. 5, 6, 9.

Pseudohaploceras jacobi (Burckhardt, 1925): Wright et al., 1996, p. 73. 


\section{Description:}

The following description is based on modifications of the original description given by Burckhardt (1925) in Spanish, and translated by Humphrey in 1949.

Shell discoidal, flattened, and involute. The last whorl embraces as much as two-thirds of preceding whorls, being more embracing toward the half closer to protoconch. The flanks are slightly convex or flattened; venter narrow and rounded. Umbilical wall almost perpendicular to the flanks forming an obtuse angle on the umbilical border.

Whorl section elongate, much higher than wide, with the greatest thickness near the umbilical region, somewhat narrowed toward the venter. The umbilicus is narrow but it widens somewhat with age.

The ornamentation on the part of the outer whorls closer to the protoconch consists of quite prominent and separated flexuous flanges ("bourrelets") and of fine flexuous intercalated costae. The flanges originate on the border of the umbilicus, are directed somewhat anteriorly on half of the flanks closer to dorsum and posteriorly on their half closer to venter. They are arched slightly toward the apertural zone when passing unaltered over the venter. Behind the flanges are visible grooves which are poorly developed. In the interspaces between the flanges two or three intercalated ribs begin on the third portion of the flanks closer to venter, but at times (especially the middle one if three are present) also toward the middle third of the flanks. These intercalated ribs are much finer than the flanges and, like them, pass unaltered over the venter, on which they are slightly arched toward the apertural zone.

There is a change in ornamentation on the half of the outer whorl closer to the aperture, where the flanges have less space in between, and resemble more the intercalated costae. One to three intercalated costae may be observed between these flanges, and some of the costae have the tendency to unite by two. The majority of the costae are restricted to the 
outer third ventral portion of the flanks, but a few of them extend into the intemal half portion or the dorsum region where they disappear gradually.

Holotype dimensions:

Total diameter: $44 \mathrm{~mm}$, Last whorl height: $21.5 \mathrm{~mm}$, Last whorl width: $13 \mathrm{~mm}$, Diameter of umbilicus: $10 \mathrm{~mm}$.

Dimensions of representative specimens of Pseudohaploceras jacobi from the Presa Francisco Zarco section

\begin{tabular}{|c|c|c|c|c|}
\hline & $\begin{array}{l}\text { Total } \\
\text { diameter }\end{array}$ & $\begin{array}{c}\text { Last Whorl } \\
\text { height }\end{array}$ & $\begin{array}{c}\text { Last Whor } \\
\text { width }\end{array}$ & $\begin{array}{l}\text { Diameter } \\
\text { of umbilicus }\end{array}$ \\
\hline Specimen PFZ-0139 & $78 \mathrm{~mm}$ & $34.27 \mathrm{~mm}$ & $28.69 \mathrm{~mm}$ & $30 \mathrm{~mm}$ \\
\hline Specimen PFZ-0144 & --- & $16.79 \mathrm{~mm}$ & $9.64 \mathrm{~mm}$ & $\omega \cdots$ \\
\hline Specimen PFZ-0149 & --- & $15.26 \mathrm{~mm}$ & $8.12 \mathrm{~mm}$ & --- \\
\hline Specimen PFZ-0159 & --- & $20.24 \mathrm{~mm}$ & $12.84 \mathrm{~mm}$ & --- \\
\hline Specimen PFZ-0164 & $\ldots$ & $15.42 \mathrm{~mm}$ & $9.77 \mathrm{~mm}$ & $m$ \\
\hline Specimen PFZ-0169 & --- & $22.12 \mathrm{~mm}$ & $12.73 \mathrm{~mm}$ & --- \\
\hline
\end{tabular}

\section{Remarks:}

Pseudohaploceras jacobi was proposed by Burckhardt (1925) from specimens collected in Durango State, northeastern Mexico. As in the case of Psendohaploceras aguilerae, Burckhardt also classified Pseudohaploceras jacobi in the genus Uhligella. The differences between the two genera are briefly mentioned in the remarks of the section of $P$. aguilerae. Pseudohaploceras jacobi resembles $P$, aguilerae, but can be easily distinguished from the latter by its higher degree of involution, its angular umbilical shoulder, and the opposite pattem of projection of the flanges across the flanks. An additional difference between the two taxa exists on the cross section of the whorl, as $P$. jacobi has its greatest thickness 
close to the umbilical region, whereas $P$. aguilerae shows its greatest thickness in the middle of the flanks.

These diagnostic characteristics of $P$. jacobi were observed in nineteen fairly well preserved specimens found in the lithologic sequence studied at Francisco Zarco, namely at the stratigraphic levels numbered 129,132, and 134 (Figure 11, in pocket). It is worth noting that $P$. jacobi was found at the same stratigraphic levels (129 and 132) as $P$. agulerae; where additional ammonite taxa were present as well. However, at stratigraphic level 134 it is remarkable that $P$.jacobi is the only taxon present in the sediment. Furthermore, while level 134 has almost the same organic carbon content as those found at levels 129 and 132 (less than $1 \%$ shown in Appendix 2 and Figure 9-c), it does not have a marly appearance Iike those beds. Instead, the rock facies at level 134 is a pure, dark, biocalcilutite that contains almost no terrigenous components.

\section{Occurrence:}

Pseudohaploceras jacobi (Burckhardt) can be considered to be an endemic species of northeastern Mexico, because it has been reponted only in rocks from the La Peña Formation. It has been found at the following localities: Loma Verde (Burckhardt, 1925) and Presa Francisco Zarco (this work) in Durango state, and Sierra de San Lucas (Humphrey, 1949), in Coahuila state. The specimens illustrated in this work are identical to those illustrated by Burckhardt, but they show marked differences with those figured by Humphrey (1949, plate 18, figures. 5m6), which are much smoother and have a narrower whorl section. Humphrey also noticed these differences in his work $(1949, \mathrm{p} .155)$, which he attributed to distortion and poor fossil preservation. Comparison between the specimens found at Francisco Zarco and those illustrated by Humphrey indicates that the morphological differences between the two sets of specimens are likely related to 
ecophenotypic variations. In my view, the differences are distinct enough to warrant further consideration of the specimens found in Coahuila state as a potential new variety

Pseudohaploceras reesidei (Humphrey, 1949)

(Plate 50, Figs. 1-16)

Uhligella reesidei Humphrey, 1949, pp. 152-153, Plate 18, Figs. 3-4.

Caseyella reesidei (Humphrey, 1949): Cantu, 1976, p. 15, Plate 1, Figs. 9-9a, $14-14 a$

Pseudohaploceras reesidei (Humphrey, 1949): Wright et al., 1996, p. 73.

\section{Description:}

The following description is emended from the original description given by Humphrey (1949);

Shell discoidal; moderately involute with last whorl embracing about two-thirds of preceding whorls. Whorl section subellipsoidal, thickest in third portion of flank closer to the dorsum; flanks flattened. Umbilicus broad, occupying about half of the total diameter; umbilical shoulder perpendicular with respect to the umbilical wall. Venter narrowly rounded in inner whorls, squarish and much wider on last part of outer whorl.

The omamentation consists of flexuous well-marked flanges, constrictions, and finer intercalated ribs. Flanges are relatively narrow but well defined and prominent. They originate on the third portion of flanks closer to dorsum, but do not extend to the umbilical shoulder. They curve with a convexity directed toward the apertural zone across the dorsal region of the flanks, and then curve with a convexity directed toward the protoconch across the remainder half portion of flanks corresponding to the ventral region, passing across the venter where they are slightly bent towards the aperturat zone. Flanges do not increase greatly in size on half part of last whorl closer to aperture, but are more widely spaced. The 
edges of the flanks facing the protoconch are bounded by shallow constrictions which are about equal in width to flanges, but they disappear before the flanges on the third portion of flanks closer to dorsum. Constrictions are more prominent on half portion of last whorl closer to the protoconch, becoming flattened and barely perceptible towards the aperture. One or two, rarely three, fine, shorter ribs intercalated between adjoining flanges, rising in interspaces at, or slightly below, middle of flanks. They are strongest on ventral half of whorl sides, being much less prominent across the ventral region. Exposed dorsum region of flanks of inner whorls are almost entirely smooth.

Holotype dimensions:

Total diameter: $34 \mathrm{~mm}$, Last whorl height: $15 \mathrm{~mm}$, Last whorl width: $9 \mathrm{~mm}$, Diameter of umbilicus: $9 \mathrm{~mm}$.

Dimensions of representative specimens of Pseudohaploceras reesidei from the Presa Francisco Zarco (PFZ) and La Boca Canyon (LBC) illustrated in the present work

$\begin{array}{cccc}\text { Total } & \text { Last Whorl } & \text { Last Whorl } & \text { Diameter } \\ \text { diameter } & \text { height } & \text { width } & \text { of umbilicus }\end{array}$

Specimen PFZ-0104

$16.20 \mathrm{~mm}$

$12 \mathrm{~mm}$

- Specimen PFZ-0109

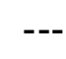

$17 \mathrm{~mm}$

Specimen PFZ-0114

$14.63 \mathrm{~mm}$

$7.93 \mathrm{~mm}$

Specimen PFZ-0124 $28.41 \mathrm{~mm}$

$12 \mathrm{~mm}$

Specimen PFZ-0129

$\quad 19.06 \mathrm{~mm}$

$13.16 \mathrm{~mm}$

Specimen PFZ-0134 $74.57 \mathrm{~mm}$

$28.89 \mathrm{~mm}$

$19.72 \mathrm{~mm}$

$25 \mathrm{~mm}$

Specimen PFZ-0318

$33 \mathrm{~mm}$

$13.81 \mathrm{~mm}$

$15.73 \mathrm{~mm}$

$11.29 \mathrm{~mm}$

Specimen PFZ 0328 $27.03 \mathrm{~mm}$

$11.40 \mathrm{~mm}$

$6.23 \mathrm{~mm}$

$7.46 \mathrm{~mm}$

Specimen PFZ-0343 $27 \mathrm{~mm}$

$11 \mathrm{~mm}$

$8.14 \mathrm{~mm}$

$9.16 \mathrm{~mm}$ 
Specimen PFZ-0348

Specimen LBC-0112

Specimen LBC-0206

Specimen LBC-0098

Specimen LBC-0108

Specimen LBC-0109

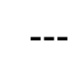

-..

---

$32.18 ? \mathrm{~mm}$

$21.16 \mathrm{~mm}$

$32.87 \mathrm{~mm}$
$10 \mathrm{~mm}$

$23 \mathrm{~mm}$

$19.15 \mathrm{~mm}$

$14 ? \mathrm{~mm}$

$11.32 \mathrm{~mm}$

$11.45 \mathrm{~mm}$
$14.15 \mathrm{~mm}$

$13.65 \mathrm{~mm}$

$12.28 \mathrm{~mm}$

$7.88 \mathrm{~mm}$

$8.07 \mathrm{~mm}$
$10.15 \mathrm{~mm}$

$4.75 \mathrm{~mm}$

$7.68 \mathrm{~mm}$

\section{Remarks:}

Pseudohaploceras reesidei was originally described by Humphrey (1949, p. 152) as Uhligella reesidei from one specimen collected in the La Peña Formation of Coahuila, Mexico. Subsequently Cantu (1976) found similar forms in a stratigraphic study of the La Peña Formation in the area of Nuevo Leon, Mexico, and proposed the new genus Caseyella to include his specimens and those classified as Uhligella aguilerae and Uhligella jacobi by Burckhardt (1925). Cantu (1976) emphasized the differences in the omamentation pattem between the Mexican specimens and the genus Uhligella, particularly because the Mexican specimens displayed strong and flexuous flanges on their shells, a morphological feature that it is not observed on specimens of the genus Uhigella from Europe. Although his observations were correct, the characteristics of the omamentation pattem displayed by the Mexican specimens are rather typical of the genus Pseudohaploceras defined by Hyat in 1900. In view of this fact, Wright et al. (1996) grouped specimens of this species under the name of Psendolaploceras reesidei (Humphrey), and they also reassigned the rest of the Mexican species previously labeled Uhligella to this genus.

Fifty two specimens have been assigned to Pseudohaploceras reesidei, as they conform to Humphrey's original description and illustrations of the taxon. They were collected at levels 129,132,136 b, 138,140 b, $142 \mathrm{a}$, and $142 \mathrm{~b}$ of the upper Aptian Cheloniceras 
inconstans Zone, and lower part of Hypacanthoplites of. leanzae Zone from the La Peña Formation at the Francisco Zarco section (Figure 11, in pocket). As indicated previously, this species is found in association with $P$. aguilerae and $P$. jacobi at levels 129 and 132 , and the characteristics of the facies of these two stratigraphic levels were also discussed. I should also emphasize that $P$. reesidei is the only species of the genus found at levels 136 $\mathrm{b}, 138,140 \mathrm{~b}, 142 \mathrm{a}$, and $142 \mathrm{~b}$, despite the fact that the lithological data show no visible difference in facies that could have prevented the presence of the other two species of the genus at these levels, which are grouped as belonging to the middle part of microfacies zone I (Figure 7). However, it is worth pointing out that levels $136 \mathrm{~b}, 138,142 \mathrm{a}$ and $142 \mathrm{~b}$ show a marked increase in organic carbon content, up to a maximum of $16.50 \%$ at stratigraphic level 138 (Appendix 2, Figure 9-c). In contrast, stratigraphic levels 129 and 132 include less than $1 \%$ organic carbon.

\section{Occurrence:}

Pseudohaploceras reesidei (Humphrey) has been reported from the La Peña Formation in Coahuila (Humphrey, 1949), Nuevo Leon (Cantu, 1976), and Durango (present study). Its apparent limited occurrence in these States of northeastern Mexico suggests that it is also a species endemic to Mexico. The three forms illustrated in previous works are morphologically identical, but the examination of fifty two specimens in the present work also shows some intraspecific variability. The difference is mainly characterized by more pronounced "fine" ribs between the flanges as they cross the ventral region than those displayed by the holotype illustrated by Humphrey. Such variation is here considered intraspecific, perhaps Humphrey was not able to notice the subtle change because the description of the species relied on only one specimen. 
Suborder Ancyloceratina Wiedmann, 1966

Superfamily Ancylocerataceae Gill, 1871

Family Ancyloceratidae Gill, 1871

Subfamily Ancyloceratinae Gill, 1871

\section{Genus Peltocrioceras Spath, 1924}

Type species. Crioceras deeckei Favre, 1908, p. 636.

\section{Peltocrioceras (?) sp.}

(Plate 51, Fig. 1)

\section{Description:}

A fragment of a heteromorph shell that appears to be part of a loosely coiled phragmocone structure has been assigned to the genus Peltocrioceras based on the description given by Wright et al. (1996, p. 216) and which has been emended from the original description of the genus given by Spath $(1924$, p. 85$)$ :

Closed criocone coiling shell. Whorl section depressed and suboctagonal. Omamentation consisting of strong, straight, or slightly prorsiradiate ribs, which give the appearance of being weakly trituberculated. All ribs fine at the inner whorls, coarsening gradually towards the outer whorl.

\section{Remarks:}

The genus Peltocrioceras was proposed by Spath (1924) to define a group of heteromorph (uncoiled) ammonites from the Aptian of Argentina, which were originally assigned to the genus Crioceras by Favre (1908).

One fragment of a heteromorph shell found on the La Peña Formation at Francisco Zarco, appears to concur with the description of a loosely colled phragmocone specimen of 
Peltocrioceras. Assignment of this fragment to Peltocrioceras $s p$ is based on similarities with the Argentinean specimen identified as Peltocrioceras deckeei by Favre (1908, p. 636), and figured by Wright et al. (1996, p. 216, fig. 168,3).

This taxon was found within a single stratigraphic level (PFZ-112) of the middle part of the middle Aptian Burckhardtites nazasensis/Rhytidoplites robentsi Zone (Figure 11, in pocket), in association with a rich assemblage of ammonites, which include Rhytidoplites robertsi, Cheloniceras fossae, Acanthohoplites acutecosta, Acanthohoplites aschiltaensis, Parahoplites mexicanus, Penaceras rursiradiatus, Kazanskyella cf. arizonica, and Acrioceras (Epacrioceras) (?) sp. An interesting aspect of this stratigraphic level is that, it is the only level in the stratigraphic sequence at Francisco Zarco where a specific ammonite taxon is confined to a single level in the lithologic record. In addition to containing the unique occurrence of Peltocrioceras sp., stratigraphic level PFZ-112 is also characterized by being the only stratigraphic record of Kazanskyella cf. arizonica Stoyanow, and Acrioceras (Epacrioceras) sp. Furthermore, this is the only stratigraphic level in the whole sequence in which heteromorph ammonites werc found.

This level falls within the middle part of microfacies zone I located in the lower part of the La Peña Formation (Figure 7). It is of interest to note that, although this package of microfacies is characterized by an alternation of black marly biocalcilutites and soft marly horizons containing abundant planktonic foraminifera, common ostracods, and echinoid fragments, level PFZ-112 is a marly horizon composed of a micritic mudstone in which all the allochems are absent, and instead contains common (between 20 and $30 \%$ ) silicic terrigenous materials. Furthermore, the total organic carbon of this stratigraphic horizon drops to $0.18 \%$ (Appendix 2, Figure 9-c). Based on the above observations, stratigraphic level PFZ-112 seems to have been deposited during a period of apparent low rate of production within the water column and a consequent low degree of benthic accumulation. 
Or perhaps, this diminishing on the benthic production could it have been due to dilution caused by a sudden imput of the terrigenous materials.

\section{Occurrence:}

The genus Peltocrioceras has only been reported from the Speeton Clay Formation of Argentina (Spath, 1924, p. 85). The finding of a fragmented shell to this genus from the La Peña Formation at Francisco Zarco in Durango State, is the first record of this taxon in northeastem Mexico. The uncertainty in assignment of this specimen to the genus Peltocrioceras is based on slight differences between the Argentinean and the Mexican specimens. Although both forms display the same type of coiling and the same type of strong ribs, such ribs are slightly projected towards the aperture in the ventrum part of the flanks on the Mexican specimen, whereas the Argentinean specimen has rectiradiate ribs. Due to the fact that there is only one fragment of the specimen with apparent similarities with Peltocrioceras deckeei and there is no reported other species within this genus with similar morphological characteristics of prorsiradiate ribs, this difference in the ornamentation pattern between the Mexican and the Argentinean specimens may be an indication of a morphological variety of Peltocrioceras deckeei (Favre).

\section{Subfamily Helicancylinae Hyatt, 1894}

\section{Genus Acrioceras Hyatt, 1900}

Type species. Ancyloceras tabarelli Astier, 1851, p. 453. 


\section{Subgenus Acrioceras (Epacrioceras) Egoian, 1974}

Type species. Epacrioceras rarum Egoian, 1974, p. 940.

\section{Acrioceras (Epacrioceras) (?) sp.}

(Plate 51, Fig. 2)

\section{Description:}

The following description is based on emendation by Wright et al. (1996, p. 223) of the original description given by Egoian (1974, p. 940).

Open spiral gyrocone shell consisting of one loosely coiled whorl, followed by a straight shaft with a terminal hook. Whorl section depressed and suboctagonal. Omamentation consisting of fine, rectiradiate ribs, which are trituberculated on the spire but not on the shaft.

\section{Remarks:}

Identification of this taxon in the present work is tentative because only one fragment of the open spire of the shell has been found. Its identification has been based on the omamentation pattern displayed by the fragment, and therefore, not all the morphological characteristics given in the description can be observed in the figured specimen:

The subgenus Acrioceras (Epacrioceras) was proposed by Egoian (1974) to better differentiate a subgroup of Acrioceras-like heteromorph (uncoiled) ammonites from the Aptian of the western Caucasus. He originally classified them under the genus Epacrioceras. One fragment that appears to be part of the straight shaft of a heteromorph ammonite shell has been assigned to this subgenus. The fragment was found at stratigraphic level 112 of the La Peña Formation at Francisco Zarco (Figure 11, in pocket), Assignment of this fragment to Acrioceras (Epacrioceras) is based on morphological similarities such as a depressed whorl section, and the rectradiate ribs of the Mexican 
specimen, found in the Caucasian specimen identified as Acrioceras (Epacrioceras) rarum (Egoian, 1974, p. 940), and figured by Wright et al. (1996, p. 223, fig. 173, 5 a, b).

The only record of this taxon in the lithologic sequences studied coincides with the occurrence of Peltocrioceras (?) sp. at the same stratigraphic level (PFZ-112). The faunal associations and facies characteristics of this stratigraphic horizon, are discussed within the remarks of the preceding taxon.

\title{
Occurrence:
}

The subgenus Acrioceras (Epacrioceras) has only been reported from the Aptian of the western Caucasus (Egoian, 1974, p. 940). Its identification from the La Peña Formation at Francisco Zarco in Durango State, northeastern Mexico, is still uncertain because it is based essentially on the ornamentation pattern of the straight portion of the shell, as the spire of this heteromorph ammonite was missing due to the state of preservation of the Mexican form.

\author{
Superfamily Douvilleicerataceae Parona \& Bonarelli, 1897 \\ Family Douvilleiceratidae Parona \& Bonarelli, 1897 \\ Subfamily Cheloniceratinae Spath, 1923
}

\section{Genus Cheloniceras Lyatt, 1903}

Type species. Ammonites cornuelianus Orbigny, 1841, p. 365, Plate 112, Figs. 3-5. 
Cheloniceras fossae Humphrey, 1949

(Plate 51, Figs. 3-7)

Cheloniceras fossae Humphrey, 1949, pp. 143-144, Plate 14, Figs. 1, 5, 6.

\section{Description:}

The following description is emended from Humphrey's original description of the species: Shell discoidal, robust, and moderately evolute with last whorl embracing about one-third of preceding whorls. Whorl section coronate, and depressed ovoidal with whorls much wider than high. Flanks flattened in early whorls, more strongly convex in older whorls. Umbilicus somewhat wide and deep occupying about half of the total diameter; umbilical shoulder strongly rounded; umbilical wall high and inclined. Venter flattened convex in young stages, broadly convex with age.

The shell shows a radical change in ornamentation with growth. Inner whorls and posterior part of last whorl are marked by simple primary ribs. They begin high on the umbilical wall, from small tuberculiform prominences on umbilical shoulder, and pass radially across flanks. On ventro-lateral margins, they form rather long, spine-shaped tubercles which shape and extend outward along umbilical wall of succeeding whorl. Above lateral tubercles, ribs thicken somewhat and form bullate swellings on each side of midline of venter, across which ribs are greatly attenuated. These early whorl ribs are rather widely separated on venter, and intervening spaces are smooth. On the anterior part of the last whorl, tubercles disappear, flanks and venter become rounded, and ribbing is irregular. Primary ribs start well down toward the lower part of the umbilical wall, incline a little posteriorly across the umbilical wall and then pass radially across flanks, increasing in size above and crossing the venter without interruption. Rarely, a single short rib may rise independently on the venter between two primaries, disappearing toward ventro-lateral margins. Interspaces smooth on venter but appear to be striated on umbilical wall. 
Holotype dimensions :

Total diameter: $36 \mathrm{~mm}$, Last whorl height: $14 \mathrm{~mm}$, Last whorl width: $24 \mathrm{~mm}$, Diameter of umbilicus: $19 \mathrm{~mm}$.

Dimensions of representative specimens of Cheloniceras fossae from Presa Francisco $\underline{\text { Zarco }}$

$\begin{array}{cccc}\begin{array}{c}\text { Total } \\ \text { diameter }\end{array} & \begin{array}{c}\text { Last Whorl } \\ \text { height }\end{array} & \begin{array}{c}\text { Last Whorl } \\ \text { width }\end{array} & \begin{array}{c}\text { Diameter } \\ \text { of umbilicus }\end{array} \\ \cdots .- & 8.39 \mathrm{~mm} & 11.25 \mathrm{~mm} & --- \\ 36.65 \mathrm{~mm} & \begin{array}{c}9.80 \mathrm{~mm} \\ ---\end{array} & 10.89 \mathrm{~mm} & 10 \mathrm{~mm} \\ 38 \mathrm{~mm} & 14.64 \mathrm{~mm} & 12.63 \mathrm{~mm} & 13.27 \mathrm{~mm}\end{array}$

\section{Remarks:}

The species Cheloniceras fossae was described by Humphrey (1949) based on observations of a single well-preserved specimen collected from the La Peña Formation at Sierra de Los Muertos area, in Coahuila State, northeastern Mexico. All species of the genus Cheloniceras are characterized by forms displaying whorl sections that resemble a crown viewed from side, but $C$. fossae is easily recognized from the rest of the species in the genus by its radical change in ornamentation with growth. As discussed by Humphrey (1949, p. 144), the only other species that presents this characteristic is Cheloniceras subnodosocostatum var. pusilla (Sinzow, 1906, pl. II, fig. 10) from the Aptian of Russia. The latter taxon also has much stronger primary ribs than $C$. fossae. Those ribs are first bituberculate and then trituberculate before changing into nodeless ribs on the living 
chamber. Furthermore, Cheloniceras subnodosocostatum var. pusilla displays two intercalated secondary ribs between each pair of primaries.

Fifteen specimens morphologically similar to the specimen identified by Humphrcy (1949) were assigned to this species. They were all found within the La Peña Formation at the Francisco Zarco section, namely at stratigraphic levels $108,110,112,113 \mathrm{c}, 122,125$, $129,136 \mathrm{c}, 137$, and $140 \mathrm{~b}$ respectively. These levels are also characterized by rich assemblages of ammonites characteristic of the middle Aptian Burckhardites nazasensis/Rhytidoplites robertsi and the upper Aptian Cheloniceras inconstans Zones (Figure 11, in pocket).

The stratigraphic distribution of this species is confined to the middle part of microfacies zone 1 of the La Peña Formation (Figure 7). This stratigraphic record is coincident with a series of planktonic foraminiferal-rich biocalcilutites, and a change in total organic carbon values which fluctuate between 0.18 and $0.77 \%$ between stratigraphic levels PFZ-108 and PFZ-129, and $10.48 \%$ and $18.39 \%$ between stratigraphic levels PFZ-136c and PFZ-140b (Appendix 2, Figure 9-c). Based on the above observations, the stratigraphic record of Cheloniceras fossae in the La Peña Formation at the Francisco Zarco section may be coincident with a span of time in which there was a change from a low rate of production period within the water column, to a period in which the production of the water column was augmented. However, these apparent changes within the water column are not indicative of any difference at all in the ammonite assemblages characteristic of both parts of the microfacies zone, as the same species can be found between the different individual stratigraphic levels.

\section{Occurrence:}

Cheloniceras fossae has not yet been reported anywhere else after its designation by Humphrey in 1949 , therefore, its geographic occurrence is confined to the La Peña 
Formation from the Sierra de Los Muertos area in Coahuila State (Humphrey, 1949), and Francisco Zarco section (present study).

It is worth mentioning that the specimens from the Francisco Zarco section examined in the present study have more rounded whorl sections than the specimen described by Humphrey. Nonetheless, there is no sufficient evidence to argue geographic differences in terms of ecophenotypic variations, since Humphrey relied his designation on a single specimen.

Cheloniceras inconstans Humphrey, 1949

(Plate 51, Figs. 8-10)

Cheloniceras inconstans Humphrey, 1949, pp. 147-148, Plate 14, Figs. 1-3.

\section{Description:}

The following description is emended after Humphrey's original description:

Shell discoidal, moderately evolute, with last whorl embracing about one-third of preceding whorl. Whorl section subovoidal. Flanks and venter evenly convex becoming flattened with increasing size. Umbilicus deep, with an umbilical shoulder strongly rounded, and a steep and high umbilical wall. Omamentation of inner whorls consists of a single row of small pointed tubercles on the ventro-lateral margin, and scarcely discernible primary ribs that extend umbilically from tubercles and appear to bifurcate over venter. On outer whorl, primary ribs begin at umbilical border in bullate tubercles and pass prominently across narrow flanks to form large bullate swellings on ventro-lateral margins. Interspaces between ribs are flat.

Holotype dimensions:

Total diameter: $25 \mathrm{~mm}$, Last whorl height: $8 \mathrm{~mm}$ ?, Last whorl width: $18 \mathrm{~mm}$, Diameter of umbilicus: $9 \mathrm{~mm}$. 
Dimensions of representative specimens of Cheloniceras inconstans from Presa Francisco

Zarco illustrated in the present work

$\begin{array}{lcccc} & \begin{array}{c}\text { Total } \\ \text { diameter }\end{array} & \begin{array}{c}\text { Last Whorl } \\ \text { height }\end{array} & \begin{array}{c}\text { Last Whorl } \\ \text { width }\end{array} & \begin{array}{c}\text { Diameter } \\ \text { of umbilicus }\end{array} \\ \text { Specimen PFZ-0125 } & 20 \mathrm{~mm} & 6.30 \mathrm{~mm} & 3.79 \mathrm{~mm} & 6 \mathrm{~mm} \\ \text { Specimen PFZ-0130 } & --- & \ldots- & 23 \mathrm{~mm} & --- \\ \text { Specimen PFZ-0140 } & --- & 13 \mathrm{~mm} & --- & \text {-..- }\end{array}$

\section{Remarks:}

Cheloniceras inconstans was proposed by Humphrey (1949) based on observations of one small, fairly well-preserved specimen collected from the La Peña Formation at Sierra de Los Muertos area in Coahuila State, northeastern Mexico. As stated by Humphrey, Cheloniceras inconstans can be easily recognized from the rest of the species of the genus by the relatively wide diameter of the whorl section, or whorl width, in relation to height of the anterior portion of the last whorl.

Fourteen specimens similar to Cheloniceras inconstans illustrated by Humphrey have been collected from the La Peña Formation at Francisco Zarco. They came from stratigraphic levels $122,125,129,132,136 \mathrm{~b}$, and $140 \mathrm{~b}$ (Figure 11 , in pocket). In general, these strata fall within the middle part of microfacies zone 1 (Figure 7), therefore, the stratigraphic range of this species is coincident with that of the previous taxon and is correlative with the package of rocks that contains the most organic carbon within the series of planktonic foraminifera-rich biocalcilutites. As pointed out previously in the case of Cheloniceras fossae, it is important to emphasize the morphology of the last whorl characterized by greater lateral broadening than dorso-ventral elongation, which usually gives a subovoidal shape to the section of the last whorl. In the case of Cheloniceras inconstans, section of the last whorl also appears to be subovoidal, but in some cases it is 
extremely depressed, as seen consistently in the fourteen specimens of this taxon collected for this study. This variable characteristic of the shell could be the result of intraspecific variations, although in some cases, the depression of the whorl section in the specimens studied in the present work may be the result of tectonic deformations.

\section{Occurrence:}

Cheloniceras inconstans has only been reported by Humphrey (1949) from the original type locality, therefore, its geographic occurrence is confined to the La Peña Formation from the Sierra de Los Muertos area in Coahuila State (Humphrey, 1949), and Francisco Zarco section (present study), as is the case of Cheloniceras fossae.

\section{Superfamily Deshayesitaceae Stoyanow, 1949 \\ Family Deshayesitidae Stoyanow, 1949 \\ Subfamily Deshayesitinae Stoyanow, 1949}

\section{Genus Burckhardtites Humphrey, 1949}

Type species. Neocomites nazasensis Burckhardt, 1925, p. 14, Plate III, Figs. 4-7.

Burckhardtites nazasensis (Burckhardt, 1925)

(Plate 51, Figs. 11-14)

Neocomites nazasensis Burckhardt, 1925, p. 14, Plate III, Figs. 4-7.

Burckhardtites nazasensis (Burckhardt, 1925): Humphrey, 1949, pp. 130-131, Plate 10, Figs. 1-5.

Burckhardtites nazasensis (Burckhardt, 1925): Cantu, 1976, p. 9, Plate I, Fig. I. 


\section{Description:}

The following description is emended from Humphrey's (1949) translation of the original description given by Burckhardt (1925) in Spanish:

Shell flattened and semi-evolute. Flanks convex passing into a not very high, but abrupt, umbilical wall. Venter truncated, flattened and narrow. Whorl section much higher than wide, oblong, with its greatest thickness somewhat within the middle of the flanks.

Ornamentation on flanks consists of narrow, fine, flexuous ribs. They consist of principal ribs which rise on the umbilical wall, and one or two intercalated ribs, which appear in the interspaces near the umbilical region, or toward the middle of the flanks. The ribs are projected towards the aperture before reaching the middle of the flanks and towards the opposite direction on the portion of the flanks closer to venter, being falciform on the part of the flanks closest to venter. The majority of the ribs are of equal strength. Only a few of the principal ribs, generally alternatively, thicken slightly on the dorsal third portion of the flanks, where they are somewhat prominent and stand out on the umbilical border as tuberculiform prominences. All ribs thicken toward the ventral margin where they end, forming slight marginal tubercles. The venter is almost entirely smooth, with only weak transverse striae present.

Dimensions of the holotype were not reported in the original description of the species by Burckhardt. However, such dimensions were reported by Humphrey $(1949$, p. 131) as follows:

Diameter: $58 \mathrm{~mm}$, Last whorl height: $27 \mathrm{~mm}$, Last whorl thickness: $15.5 \mathrm{~mm}$, Diameter of umbilicus: $18 \mathrm{~mm}$. 
Dimensions of representative specimens of Burckhardtites nazasensis from Presa Francisco

Zarco illustrated in the present work

$\begin{array}{lcccc} & \begin{array}{c}\text { Total } \\ \text { diameter }\end{array} & \begin{array}{c}\text { Last Whorl } \\ \text { height }\end{array} & \begin{array}{c}\text { Last Whorl } \\ \text { width }\end{array} & \begin{array}{c}\text { Diameter } \\ \text { of umbilicus }\end{array} \\ \text { Specimen PFZ-0352 } & 27 \mathrm{~mm} & 11.21 \mathrm{~mm} & -10 \mathrm{~mm} \\ \text { Specimen PFZ-0103 } & 41 ? \mathrm{~mm} & 20.31 \mathrm{~mm} & 5.73 \mathrm{~mm} & 14 ? \mathrm{~mm} \\ \text { Specimen PFZ-0113 } & --- & 23 \mathrm{~mm} & 7.59 \mathrm{~mm} & \ldots . . \\ \text { Specimen PFZ } 0347 & 75 ? \mathrm{~mm} & 33 \mathrm{~mm} & 10.86 \mathrm{~mm} & 25 ? \mathrm{~mm}\end{array}$

\section{Remarks:}

The genus Burckhardtites was introduced by Humphrey $(1949$, p. 130) to include all forms described by Burckhardt (1925, p. 14, plate II, figs. 4-7) as Neocomites nazasensis from the Aptian of Rio Nazas, Durango, Mexico. As argued by Humphrey, the genus Neocomites disappeared in the Hauterivian and is characterized by very involute, much compressed forms with ribs inclined towards the apertural zone, equally spaced, and which bifurcate from umbilical tubercles located at mid flanks (Humphrey, 1949, p. 130). Burckhardites nazasensis (Burckhardt) is an Aptian species which is more related to Dufrenoyia, than it is to Neocomites (Wright et al., 1996, p. 273). Nonetheless, Burckhardtites, can be easily separated from Dufrenoyia by its whorl height that increases more rapidly, and its fine, irregular, biconcave ribs. Five specimens were collected within the lithologic sequence at Francisco Zarco at stratigraphic levels 101, 104, and 106 (Figure 11, in pocket), respectively. The stratigraphic range of the specimens at this locality is coincidental with the lower part of the middle Aptian Burckhardtites nazasensis/Rhytidoplites robentsi Zone (Figure 11, in pocket). Their morphologic characteristics are in agreement with Burckhardt's original description and illustrations, and were therefore identified as Burckharditites nazasensis (Burckhardt). These three 
stratigraphic levels fall within the middle pat of microfacies zone 1(Figure 7), belonging to the lower part of the La Peña Formation. The strata of the middle part of microfacies zone I are characterized by very low organic carbon content (less than $1 \%$, as shown in Figure 9c), and they consist of biocalcilutites with common planktonic foraminifera, ostracods, and echinoid fragments. Although Burckhardites nazasensis was found at these levels in association with species of the genus Dufrenoyia, it is worth noting that the appearance of B. nazasensis at stratigraphic level 101 is also concident with a marked decrease in the abundance of Dufrenoyia specimens, which are extremely abundant from stratigraphic levels 61 to 97, prior to the appearance of Burckhardtites (Figure 11, in pocket).

\section{Occurrence:}

The present record of Burckhardtites Humphrey, 1949, indicates that the genus can be considered endemic to Mexico. Burckhardtites nazasensis (Burckhardt) has only been reported from the La Peña Formation in three states of northeastern Mexico, namely Durango (Burckhard, 1925; and present study), Coahuila (Humphrey, 1949), and Nuevo Leon (Cantu, 1976). All specimens illustrated from the different studies are very similar, indicating no perceivable variation of the species from one locality to the other.

\section{Genus Dufrenoyia Kilian and Reboul, 1915}

Type species. Ammonites dufrenoyi Orbigny, 1840, p. 200, Plate 33, Figs. 4-6.

Dufrenoyia bösei Humphrey, 1949

(Plate 52, Figs. 1-7)

Dufrenoyia bösei Humphrey, 1949, pp. 126-127, Plate 9, Figs. 1-2. 


\section{Description:}

This description is emended from Humphrey's original description of the species:

Shell discoidal; compressed; with whorls increasing rapidly in height, slowly in width, semi-involute with last whorl embracing more than half of preceding whorls. Whorl section elongate-ellipsoidal, thicker in third portion closer to dorsum. Flanks flattened, inclined toward venter, evenly convex toward dorsum. Umbilicus shallow, rather small for the genus, occupying about one-third of total diameter of shell. Umbilical wall low, gently inclined; umbilical shoulder rounded. Venter truncated and narrow, flattened in young whorls, somewhat convex on older whorls.

Ornamentation of inner whorls consists of ribs that originate on umbilical shoulder, regularly bifurcate on dorsal portion or at mid flank, sometimes bending towards the apertural zone across ventral third portion of whorl sides. They cross the venter in a straight line, forming small clavi on prominent ventro-lateral margins. On the last half of the outer whorl, sculpture consists of regularly alternating, falciform primary and secondary ribs. Primaries originate on the umbilical wall, are directed obliquely prorsiradiate on third dorsum portion of flanks, rursiradiate or radial on middle flank, and curve prorsiradiate again on ventral third portion of flank to form indistinct, thickened clavi on ventro-lateral angles. Secondaries originate on third portion of flanks closer to ventral region. All ribs equal on venter, where they swing slightly anteriorly. Both primaries and secondaries fade in relief with age, becoming indistinct on outer part of last whorl, where all ribs widen and are gently rounded toward venter, being broader than the interspaces.

Holotype dimensions :

Total diameter: 61 ? mm, Last whorl height: $31 \mathrm{~mm}$, Last whorl width: $13 \mathrm{~mm}$, Diameter of umbilicus: $15 \mathrm{~mm}$. 
Dimensions of representative specimens of Dufrenoyia bösei from Presa Francisco Zarco illustrated in the present work

\begin{tabular}{|c|c|c|c|c|}
\hline & $\begin{array}{l}\text { Total } \\
\text { diameter }\end{array}$ & $\begin{array}{c}\text { Last Whorl } \\
\text { height }\end{array}$ & $\begin{array}{l}\text { Last Whorl } \\
\text { width }\end{array}$ & $\begin{array}{l}\text { Diameter } \\
\text { of umbilicus }\end{array}$ \\
\hline Specimen PFZ-0330a & $56 \mathrm{~mm}$ & $25 \mathrm{~mm}$ & $6.36 \mathrm{~mm}$ & $12 \mathrm{~mm}$ \\
\hline Specimen PFZ-0341 & $44.59 \mathrm{~mm}$ & $22.68 \mathrm{~mm}$ & $-\ldots$ & $14 \mathrm{~mm}$ \\
\hline Specimen PFZ-0351 & $27.11 \mathrm{~mm}$ & $11.24 \mathrm{~mm}$ & - $\cdots$ & $9 \mathrm{~mm}$ \\
\hline Specimen PFZ-0102 & $60 \mathrm{~mm}$ & $25 \mathrm{~mm}$ & $5.63 \mathrm{~mm}$ & $12 \mathrm{~mm}$ \\
\hline Specimen PFZ $0145 b$ & $39 \mathrm{~mm}$ & $16 \mathrm{~mm}$ & $4.52 \mathrm{~mm}$ & $8 \mathrm{~mm}$ \\
\hline Specimen PFZ-0190b & --- & $17.04 \mathrm{~mm}$ & $5.09 \mathrm{~mm}$ & --- \\
\hline Specimen PFZ-0326 & $38 \mathrm{~mm}$ & $13.54 \mathrm{~mm}$ & $\sim \sim$ & $10 \mathrm{~mm}$ \\
\hline
\end{tabular}

\section{Remarks:}

Dufrenoyia bösei was described by Humphrey (1949, pp. 126 127) from a specimen collected in the La Peña Formation of Durango State, northeastern Mexico.

The most striking features that distinguish Dufrenoyia bösei Humphrey, found in northeastern Mexico, from the more widespread Dufrenoyia justinae (Hill), are the characteristic bifurcation of the ribs at the early stages of the shell, and the straight line all these ribs form when they cross the venter. Representative specimens of Dufrenoyia bösei also display a much wider ventral region than specimens of $D$. justinae. These characteristics were observed in 14 fairly well preserved specimens found in the lithologic sequence studied at Francisco Zarco, namely at stratigraphic levels 67, 69, 71, 73, 81, and 85 respectively, of the lower Aptian Dufrenoyia justinae Zone (Figure 11, in pocket). These stratigraphic levels fall within the lower part microfacies zone I corresponding to the lowermost part of the La Peña Formation (Figure 7). This microfacies zone consists of a series of well consolidated black marly biocalcilutites alternating with marly soft horizons. 
Bioclasts in these rocks include abundant planktonic foraminifera, common ostracods, and echinoid fragments. It is particularly remarkable that all species belonging to the genus Dufrenoyia identified in the present study are found in strata within this microfacies package, which is also characterized by a high content of terrigenous components, which ranges from 20 to $30 \%$ along the single stratigraphic horizons. However, it is worth noting that Dufrenoyia bösei is limited to the black biocalcilutites of the lower part of microfacies package I. These levels are coincident with strata whose values in organic carbon content vary in the order of 1 to $7 \%$ (Appendix 2, Fig. 9mb).

\section{Occurrence:}

Dufrenoyia bösei is found in the La Peña Formation at Rancho El Mulato (Humphrey, 1949), and at the Francisco Zarco section (present work) of Durango State, northeastern Mexico. There is no report in the literature of the presence of this species elsewhere. The forms from the two localities are very similar, with no perceivable geographic morphological variations.

\section{Dufrenoyia dufrenoyi (d'Orbigny, 1840)}

(Plate 52, Figs. 8-14; Plate 53, Fig. 1)

Ammonites dufrenoyi d'Orbigny, 1840, p. 200, Plate XXXIII, Figs. 4-6.

Ammonites dufrenoyi d'Orbigny, 1840: Quenstedt, 1849, p. 158, Plate V, Figs. $10 \mathrm{a}-\mathrm{b}$.

Hoplites (Neocomites) furcatus (Sowerby, 1836): Kilian, 1910, Plate VIII, Figs. 3 a-b.

Parahoplites furcatus Sowerby, 1836: Kilian and Reboul, 1915, pp. 34-35, Fig. 4.

Dufrenoyia aff. dufrenoyi (d'Orbigny, 1840): Burckhardt, 1925, p. 18, Plate X, Figs. 1-4, $7-9$.

Dufrenoyia dufrenoyi (d'Orbigny, 1840): Humphrey, 1949, pp. 123-124, Plate 8, Figs. $1-6$. 
Dufrenoyia aff. dufrenoyi (d'Orbigny, 1840): Cantu, 1976, p. 9, Plate 1, Fig. 13.

\section{Description:}

The following is emended from d'Orbigny's original description modified by Humphrey in 1949:

Shell discoidal, compressed, with whorls increasing rapidly in height, slowly in width; semi-evolute with last whorl embracing preceding whoris by about one-half. Whorl section much higher than wide, thickest in dorsal third portion of flanks which arc convex, but become flattened and inclined toward venter. Umbilicus shallow, moderately small, occupying about one-third of total diameter of the shell; umbilical wall low, steeply inclined; umbilical shoulder strongly rounded. Venter truncate, flattened, and may be slightly excavated.

Shell marked by regularly alternating, somewhat falciform primary and secondary ribs. Primaries begin on umbilical shoulder, display a convexity directed toward the apertural zone on the dorsal region of flanks, becoming concave respect to the same apertural zone on ventral region of flanks; most prominent umbilically, widen and flatten toward venter and terminate in small, weakly clavate prominences on ventro-lateral angles. Secondaries rise near mid flanks; usually only one is intercalated between adjoining primaries. Venter typically smooth or marked by faint swellings between paired clavi.

The following is Humphrey's (1949) translation of d'Orbigny's original description given in French for Ammonites dufrenoyi. Note that the terminology used in the orientation of the different parts of the shell is in reverse of the modern terminology, because In 1949 , Humphrey introduced a modified description of the species in which he referred to, "dorsum" and "dorsal" in d'Orbigny's original description to correspond to "venter" and 
"ventral" in modern terminology (this was due to the newly accepted reorientation of the shell):

"Shell suborbicular, very compressed, transversely omamented per whorl by 27 to 36 long flexuous ribs, widening toward the periphery where each forms a weak tubercle. Of these ribs, some, altematively, extend from the dorsum to the umbilical border, while the others occupy only the upper two-thirds of the whorl. Spire growing very rapidly, fonned of compressed whorls with truncated dorsum (which is smooth), ornamented on each side by compressed paired tubercles, corresponding to the terminations of the ribs. In the umbilicus the whorls are exposed to about one-lalf of their height. The umbilicus is about 45/100 of the overall diameter. The aperiure is very compressed, narrowed forward, tnincated above, forming the two angles. Sutures deeply incised, divided laterally in four lobes composed of unequal parts. Dorsal lobe as wide, but shorter than the upper lateral lobe, omamented on each side by three branches, of which the lowest has four digitations. Dorsal saddle almost twice the width of the dorsal lobe, divided by an accessory lobe in two parts, themselves incised, being each divided in two. The upper lateral lobe a little more than ltalf as wide as the dorsal saddle, formed of a single trunk adomed by five branches, of which the lower median one has nine digitations divided in three smaller branchlets. Lateral saddle about one half the width of the dorsal saddle, separated in two unequal parts, the lower being the largest. Lower lateral lobe and the two following lobes become less and less complicated, the same being true of the succeeding saddles. The upper part of the last suture shows a dorsal lobe with a snall lateral lobe on each side."

Dimensions of the French Holotype were not reported in the original description. The following are the variations in range of dimensions expressed in millimeters (mm), between French and Mexican hypotypes of Dufrenoyia dufrenoyi (d'Orbigny, 1840), as observed 
on six Mexican specimens and two French hypotypes illustrated by Humphrey (1949, p. 124):

French forms

Total diameter:

Last whorl height:

Last whorl width:

Diameter of umbilicus:
$22.0-41.4 \mathrm{~mm}$

$10.0-18.2 \mathrm{~mm}$

$6.7-11.0 \mathrm{~mm}$

$6.3-12.8 \mathrm{~mm}$
Mexican forms

$31.5-44.5 \mathrm{~mm}$

$14.8-19.5 \mathrm{~mm}$

$9.0 \times 15.0 \mathrm{~mm}$

$9.0-15.0 \mathrm{~mm}$

Dimensions of representative specimens of Dufrenovia dufrenovi from Presa Francisco Zarco illustrated in the present work

$\begin{array}{lcccc} & \begin{array}{c}\text { Total } \\ \text { diameter }\end{array} & \begin{array}{c}\text { Last Whorl } \\ \text { height }\end{array} & \begin{array}{c}\text { Last Whorl } \\ \text { width }\end{array} & \begin{array}{c}\text { Diameter } \\ \text { of umbilicus }\end{array} \\ \text { Specimen PFZ-0226a } & 28.72 \mathrm{~mm} & 13 \mathrm{~mm} & 4.08 \mathrm{~mm} & 5 \mathrm{~mm} \\ \text { Specimen PFZ-0241 } & 20 ? \mathrm{~mm} & 8.35 \mathrm{~mm} & 2.14 \mathrm{~mm} & 5 \mathrm{~mm} \\ \text { Specimen PFZ-0266 } & 19.64 \mathrm{~mm} & 8.36 \mathrm{~mm} & --- & 5 \mathrm{~mm} \\ \text { Specimen PFZ-0301 } & \ldots-m & 12 \mathrm{~mm} & 3.85 \mathrm{~mm} & 7 \mathrm{~mm} \\ \text { Specimen PFZ-0321 } & 24.46 \mathrm{~mm} & 10.17 \mathrm{~mm} & 2.56 \mathrm{~mm} & 6.28 \mathrm{~mm} \\ \text { Specimen PFZ-0261 } & 32.82 \mathrm{~mm} & 15.34 \mathrm{~mm} & 5.20 \mathrm{~mm} & 8.12 \mathrm{~mm} \\ \text { Specimen PFZ-0271 } & 103.25 \mathrm{~mm} & 42 \mathrm{~mm} & 9.19 \mathrm{~mm} & 23.12 \mathrm{~mm}\end{array}$

\section{Remarks:}

Dufrenoyia dufrenoyi (d'Orbigny) is morphologically similar to Dufrenoyia justinae (Hill), but can be distinguished from it by a denser ribbing and a flat and ribless venter. However, as pointed out by Stoyanow (1949), this characteristic of the ventral region of the species is seen only in the mature stages of the specimens, since in the early growing stages, the ribs cross the venter without any peripheral angulation. Another difference between the two 
species is that in Dufrenoyia justinae (Hill), the primary ribs originate on the umbilical wall, whereas in Dufrenoyia dufrenoyi (d'Orbigny), they originate on the umbilical shoulder. Thirty five specimens assigned to Dufrenoyia dufrenoyi (d'Orbigny) were found at stratigraphic levels $67,71,73,75,79,81,85,89,91,93,96,97,101,104$, and 106, respectively in the Francisco Zarco section (Figure 11, in pocket). As in the case with Dufrenoyia bösei Humphrey, specimens of $D$. dufrenoyi were found at intermittent intervals within microfacies zone I of the lower part of the La Peña Formation (Figure 7). They occur concomitantly with Dufrenoyia bösei. Similarly, the LAD of $D$. dufrenoyi (level PFZ-106) in the section is coincident with a decrease in the organic carbon content where it reached values to less than $1 \%$ (Figure $9 \mathrm{~b}-\mathrm{c}$ ) within microfacies zone I (Figure 8). An interesting aspect of this species of the genus Dufrenoyia, is that it is not confined to the lower Aptian Dufrenoyia justinae Zone, but it crosses into the middle Aptian Burckhardtites nazasensis/Rhytidoplites robertsi Zone. (Figure 11, in pocket)

\section{Occurrence:}

Specimens with attributes that can be assigned to Dufrenoyia dufrenoyi have been found in southeastem France, southern Germany, northeastern Mexico, Angola, the Eastern Cordillera of Colombia, and Venezuela. All specimens studied in the present work are morphologically similar to the specimens from France identified as Ammonites dufrenoyi originally described and illustrated by d'Orbigny in 1840. Another specimen from France identified as Parahoplites furcatus (Sowerby) by Kilian and Reboul in 1915, can also be assigned to Dufrenoyia dufrenoyi, although the Mexican specimens reported in this work, as well as those reported by Humphrey (1949) show a higher degree of flattening of the ribs toward the venter. 
Dufrenoyia durangensis Humphrey, 1949, p. 127, Plate 9, Figs. 3-4.

\section{Description:}

This description is emended from Humphrey's original description of the species:

Shell discoidal and compressed. Whorl section ellipsoidal, almost rectangular, about three times as high as wide, slightly wider in third portion closer to umbilicus. Semi-evolute, with last whorl embracing about one-half of preceding whorls. Umbilicus narrow, occupying about one-third of total shell diameter, umbilical wall inclined and rounded. Venter truncated, narrow, slightly convex.

Omamentation consists of regularly altemating, falciform primary and secondary ribs. Primaries originate at umbilical wall, curve gently toward aperture across umbilical shoulder, and in opposite direction on mid flank, and slightly toward aperture again to form ventrolateral margins. Secondary ribs originate toward the middle or close to the ventral portion of the flanks. All ribs flatten and widen considerably towards the venter and form well -developed, narrow clavi on ventro-lateral angles, Ribs cross the venter transversely as low swellings between paired clavi. All ribs wider than interspaces on ventrum portion of flanks and become more widely separated on anterior portion of outer whorl.

Holotype dimensions:

Total diameter: $43 \mathrm{~mm}$, Last whorl height: 19 ? mm, Last whorl width: $6 \mathrm{~mm}$, Diameter of umbilicus: $11.7 \mathrm{~mm}$. 
Zarco illustrated in the present work

$\begin{array}{lcccc} & \begin{array}{c}\text { Total } \\ \text { diameter }\end{array} & \begin{array}{c}\text { Last Whorl } \\ \text { height }\end{array} & \begin{array}{c}\text { Last Whorl } \\ \text { width }\end{array} & \begin{array}{c}\text { Diameter } \\ \text { of umbilicus }\end{array} \\ \text { Specimen PFZ-0297 } & 44 \mathrm{~mm} & 19.18 \mathrm{~mm} & 2.09 \mathrm{~mm} & 12 \mathrm{~mm} \\ \text { Specimen PFZ-0302 } & 34 ? \mathrm{~mm} & 15 \mathrm{~mm} & 1.62 \mathrm{~mm} & 10 \mathrm{~mm} \\ \text { Specimen PFZ-0307 } & 41 \mathrm{~mm} & 18.85 \mathrm{~mm} & 2.28 \mathrm{~mm} & 11.18 \mathrm{~mm}\end{array}$

\section{Remarks:}

Dufrenoyia durangensis was described by Humphrey (1949) to distinguish specimens that resembled Dufrenoyia dufrenoyi (d'Orbigny) in a sample collected from Coahuila State in northeastem Mexico. These specimens differed from Dufrenoyia dufrenoyi by the flattening and widening of the ribs toward the venter, and by the development of prominent swellings as angular projections between paired clavi on the ventro-lateral region. In the present study, sixteen specimens studied from the Francisco Zarco section at levels 79, 81, 85,93 , and 96 (Figure 11 , in pocket) show additional differences between the two species: Dufrenoyia dufrenoyi (d'Orbigny) has primary ribs that originate in the umbilical shoulder, whereas in Dufrenoyia durangensis Humphrey the ribs oniginate in the umbilical wall. Also, specimens assigned to Dufrenoyia durangensis from Francisco Zarco display a more prominent projection of the ventro-lateral clavi than those illustrated by Humphrey (1949). The emended description given herein complement that given by Humphrey who based his original description of Dufrenoyia durangensis on an incomplete specimen. His observations were certainly incomplete to describe the whole shell, and therefore he could not observe details of the nature of the costulation across the venter of this species. Because of a lack of data he described costulation as: "Ribs appear to cross venter transversely only as low swellings between paired clavi". My observations of 16 specimens further 
corroborates the initial observation as the ribs cross the venter transversally as low swellings between paired clavi. This species is confined to the lower Aptian Dufrenoyia justinae Zone (Figure 11, in pocket).

\section{Occurrence:}

Dufrenoyia durangensis is considered as endemic to Mexico, because it has only been reported from the La Peña Formation of the states of Durango and Coahuila, in northeastern Mexico. This taxon is also found concurrently with $D$. bösei and $D$. dufrenoyi.

Dufrenoyia justinae (Hill, 1893)

(Plate 53, Figs. 5-10; Plate 54, Figs. 1-12; Plate 55, Figs. 1-6)

Acanthoceras ?justinae Hill, 1893, p. 38, Plate V1l, Figs. 1-3.

Hoplites roemeri Cragin, 1893, p.234, Plate XLIV, Figs. $4-5$.

Ammonites justinae (Hill, 1893): Hill, 1901, Plate XX, Fig. 6.

Hoplites furcatus (Sowerby, 1836): Kilian in Lasswitz, 1904, p. 4, Fig, 1 .

Dufrenoyia justinae (Hill, 1893): Burckhardt, 1925, p. 17, Plate X, Figs. 14-15.

Dufrenoyia texana Burckhardt, 1925, p. 20, Plate IX, Figs. 2-15.

Dufrenoyia texana Burckhardt, 1925: Riedel, 1938, pp. 48-49, Plate VIII, Figs. 15, 19; Plate XIV, Fig. 25.

Dufrenoyia justinae (Hill, 1893): Scott, 1940 a, pp. 1022-1025, Plate LX, Figs. 7-8; Plate LXII, Fig. 9.

Dufrenoyia justinae (Hill, 1893): Shimer and Shrock, 1944, p. 589, Plate 243, Figs. 1516. 
Dufrenoyia justinae (Hill, 1893): Humphrey, 1949, p.122, Plate 6, Figs. 1-7; Plate 7, Figs. 1-9.

Dufrenoyia justinae (Hill, 1893): Stoyanow, 1949, pp. 124-125, Plate 21, Figs. 11-17.

Dufrenoyia texana Burckhardt, 1925: Bürgl, 1956, pp. 1-22, Plate I-III.

Dufrenoyia justinae (Hill, 1893): Cantu, 1963, pp. 57-58, Plate IV, Fig. 6.

Dufrenoyia aff. justinae (Hill, 1893): Cantu, 1976, p. 9, Plate 1, Figs. 3, 5, 11-11a.

\section{Description:}

Humphrey (1949), redescribed Dufrenoyia justinae based on comparison between Mexican specimens from Coahuila State and topotypes from Texas, which were made available to him through the courtesy of the United States National Museum and the Texas Bureau of Economic Geology.

The following is an emended description based on Humphrey's (1949) description:

Shell discoidal; compressed; with whorls increasing rapidly in height, slowly in width; semi-evolute with last whorl embracing about one-third of preceding whorls. Whorl section ellipsoidal, widest in third portion closest to umbilicus; flanks slightly convex toward dorsum, flattened and inclined toward venter. Umbilicus shallow, moderately narrow, about one third of total diameter; umbilical wall oblique; umbilical shoulder moderately rounded. Venter truncated, flattened and squarish, with pronounced ventro-lateral angles. Omamentation consists of falciform, regularly alternating, primary and secondary ribs. Primaries begin on umbilical wall, curve convexly toward aperture on third portion of flank closest to umbilicus, and are convex toward the opposite direction in the middle of the flank, bending toward the aperture again in the ventral portion of the flanks, to form clavate tubercles on ventro-lateral angles. Secondary ribs originate in the middle region of the flanks and are equal in strength to primaries on the ventral third region of flanks. All ribs 
are of equal prominence and evenly spaced on venter, which they cross transversely. In profile, ribs on venter are flattened or may be higher posteriorly and inclined towards the aperture, giving a "cog-wheel" appearance to the venter. Density of ribbing usually greater on young whorls, with ribs becoming coarser and more separated with age, although rather evenly spaced.

Range of dimensions between hundreds of different Mexican hypotypes as observed by Humphrey $(1949$, p. 123$)$ are as follows:

Total diameter: $26-80$ ? $\mathrm{mm}$, Last whorl height: 10-42 mm, Last whorl width: 9?-24? mm, Diameter of umbilicus: $8-26.7 \mathrm{~mm}$.

Dimensions of representative specimens of Dufrenoyia instinae from Presa Francisco Zarco (PFZ) and La Boca Canyon (LBC) illustrated in the present work

$\begin{array}{lcccc} & \begin{array}{c}\text { Total } \\ \text { diameter }\end{array} & \begin{array}{c}\text { Last Whorl } \\ \text { height }\end{array} & \begin{array}{c}\text { Last Whorl } \\ \text { width }\end{array} & \begin{array}{c}\text { Diameter } \\ \text { of umbilicus }\end{array} \\ \text { Specimen PFZ-0230 } & 37.08 \mathrm{~mm} & 16.45 \mathrm{~mm} & 5.88 \mathrm{~mm} & 11.23 \mathrm{~mm} \\ \text { Specimen PFZ-0135 } & --- & 11.59 \mathrm{~mm} & 4.40 \mathrm{~mm} & 7.88 \mathrm{~mm} \\ \text { Specimen PFZ-0185 } & 29.38 \mathrm{~mm} & 11.33 \mathrm{~mm} & 4.32 \mathrm{~mm} & 8.87 \mathrm{~mm} \\ \text { Specimen PFZ-0300 } & 47.02 \mathrm{~mm} & 19.64 \mathrm{~mm} & \ldots .+1 & 12.22 \mathrm{~mm} \\ \text { Specimen PFZ-0350 } & 37.86 \mathrm{~mm} & 14.90 \mathrm{~mm} & 3.96 \mathrm{~mm} & 12.85 \mathrm{~mm} \\ \text { Specimen PFZ-0106 } & 42.23 \mathrm{~mm} & 16.12 \mathrm{~mm} & 5.77 \mathrm{~mm} & 11.12 \mathrm{~mm} \\ \text { Specimen PFZ-0126 } & 31.08 \mathrm{~mm} & 12.67 \mathrm{~mm} & 4.53 \mathrm{~mm} & 8.92 \mathrm{~mm} \\ \text { Specimen PFZ-0131 } & 49.28 \mathrm{~mm} & 17.54 \mathrm{~mm} & 5.96 \mathrm{~mm} & 10.28 \mathrm{~mm} \\ \text { Specimen PFZ-0146 } & 35.53 \mathrm{~mm} & 14.61 \mathrm{~mm} & 5.44 \mathrm{~mm} & 8.42 \mathrm{~mm} \\ \text { Specimen PFZ-0180 } & 41.23 ? \mathrm{~mm} & 18.21 ? \mathrm{~mm} & --- & 12.52 ? \mathrm{~mm} \\ \text { Specimen PFZ-0265 } & --- & 17.06 \mathrm{~mm} & 4.92 \mathrm{~mm} & ---\end{array}$




$\begin{array}{lcccc}\text { Specimen PFZ-0270 } & 48.54 \mathrm{~mm} & 20.07 \mathrm{~mm} & 4.32 \mathrm{~mm} & 11.12 \mathrm{~mm} \\ \text { Specimen PFZ-0175 } & 32.85 \mathrm{~mm} & 14.25 \mathrm{~mm} & 4.42 \mathrm{~mm} & 10.23 \mathrm{~mm} \\ \text { Specimen PFZ-0191 } & 45.90 \mathrm{~mm} & 20.79 \mathrm{~mm} & --- & 12.32 \mathrm{~mm} \\ \text { Specimen PFZ-0110 } & --- & 16.81 \mathrm{~mm} & 11.16 \mathrm{~mm} & \ldots-\cdots \\ \text { Specimen PFZ-0181 } & 36.72 \mathrm{~mm} & 14.46 \mathrm{~mm} & --- & 11.85 \mathrm{~mm} \\ \text { Specimen PFZ-0295 } & 49.04 \mathrm{~mm} & 19.11 \mathrm{~mm} & 8.52 \mathrm{~mm} & 11.15 \mathrm{~mm} \\ \text { Specimen PFZ-0115 } & 59.05 ? \mathrm{~mm} & 22.73 ? \mathrm{~mm} & 7.28 ? \mathrm{~mm} & 19.28 ? \mathrm{~mm} \\ \text { Specimen PFZ-0190 } & 47.59 \mathrm{~mm} & 20.46 \mathrm{~mm} & 7.47 \mathrm{~mm} & 12.72 \mathrm{~mm} \\ \text { Specimen PFZ-0200 } & --- & 14.25 \mathrm{~mm} & 6.93 \mathrm{~mm} & -\cdots \\ \text { Specimen PFZ-0105 } & 100.88 \mathrm{~mm} & 39.86 \mathrm{~mm} & 14.20 \mathrm{~mm} & 33.52 \mathrm{~mm} \\ \text { Specimen LBC-0002 } & --- & 34.28 \mathrm{~mm} & 12.56 \mathrm{~mm} & 22.24 \mathrm{~mm} \\ \text { Specimen LBC-0024 } & 51.18 \mathrm{~mm} & 22.65 \mathrm{~mm} & 7.34 \mathrm{~mm} & ---\end{array}$

\section{Remarks:}

Dufrenoyia justinae (Hill) is easily recognized by the characteristics of its ventral region, particularly by the squared venter and the prominence of the ribs when they cross it transversely, Dufrenoyia bösei (Humphrey) is distinguished from Dufrenoyia justinae (Hill) by a regular bifurcation of the ribs, and by the fact that these ribs cross the rounded venter in a straight line. Dufrenoyia dufrenoyi (d'Orbigny), on the other hand, differs from Dufrenoyia justinae (Hill) by its ribs that terminate in the ventrolateral clavi and they do not cross the venter. Dufrenoyia justinae is by far the most abundant species of the genus identified in the study area. Two hundred and six fairly well preserved specimens of this species were found at stratigraphic levels $61,63,65,67,68,69,71,73,75,79,81,85$, $89,91,93,96,97$ and 101, respectively within the lower part of the La Peña Formation at the Francisco Zarco section, and spanning the complete lower Aptian Dufrenoyia justinae Zone (Figure 11, in pocket). In contrast, only nine specimens of the same species were 
sampled at stratigraphic levels A-17, E-4, G-11, G-14, G-31 and $1-16$, respectively, also from the lower part of the La Peña Formation at La Boca Canyon section (Figure 6). Dufrenoyia justinae is the only ammonite species recorded within microfacies subunit $H$, and occurs concurrently with $D$. bösei and $D$. dufrenoyi within microfacies zone I of the Francisco Zarco section (Figure 7). The sedimentological characteristics associated with these levels were discussed with these respective taxa They mainly consist of a series of well consolidated black marly biocalcilutites alternating with marly soft horizons, and which contain planktonic foraminifera, ostracods, and echinoid fragments. It is also worth noting that Dufrenoyia justinae is one of the few species found at La Boca Canyon section at stratigraphic levels which display similar characteristics as those from microfacies zone $\mathrm{H}$ at Francisco Zarco. These facies are monotonous series of biocalcilutites on which planktonic foraminifera, ostracods, and intraclasts, make up between 60 and $70 \%$ of the allochems, and rare echinoid and molusk fragments along with terrigenous grains make up between the 30 and $40 \%$ of the remaining allochemical composition. The organic carbon content of these rocks varies between 7 and $17 \%$ (Fig, 9 b-c, Appendix 2).

Another important aspect of this taxon, is that its FAD marks the first stratigraphic record of the ammonites within the Francisco Zarco section. This can be easily observed in the chart of the stratigraphic distribution of the ammonite species (Figure 11, in pocket).

\section{Occurrence:}

Dufrenoyia justinae has been reported from the La Peña Formation of northeastern Mexico, from the Cow Creek member of the Travis Peak Formation in Texas, from the Cholla member of the Lowell Formation in Arizona, and from beds with Cheloniceras (Upper Aptian), Sierra de Bogota, Colombia. Bürgl (1956) proposed several varieties of Dufrenoyia justinae based on differences in the ventral region of the shells of specimens from Mexico, and identified as Dufrenoyia texana by Burckhardt (1925), as well as on 
comparison of specimens from Texas, and Colombia. Specimens studied in the present work have been compared to those reported by Burckhardt (1925) and Humphrey (1949) from northeastern Mexico, as well as those studied by Stoyanow (1949) and Scott (1940a) from Arizona and Texas, respectively, and those illustrated by Riedel (1938) from the Sierra de Bogota, Colombia. All the forms from these different areas are here considered conspecific with Dufrenoyia justinae, and the differences observed on the ventral region on all of them can be easily considered within the range of variation within the species.

Dufrenoyia scotti Humphrey, 1949

(Plate 56, Figs. 1-5)

Dufrenoya aff. dufrenoyi (d'Orbigny): Scott, 1940a, p. 1027, Plate 62, Figs. 344.

Dufrenoyia scotti Humphrey, 1949, pp. 128-129, Plate 9, Figs. 5-6.

\section{Description:}

This description is based on modifications to Humphrey's (1949) original description of the species:

Shell discoidal and compressed; flanks flattened and inclined toward the ventral region. Whorl section subellipsoidal, more than twice as wide as high, thickest in third portion of flank closer to dorsum. Umbilicus moderately wide, occupying about two-thirds of total diameter; umbilical wall steep; umbilical shoulder rounded. Venter truncate and flattened, with prominent ventro-lateral angles.

Ornamentation consists of flexuous to almost radial, widely spaced and fine primary and secondary ribs which alternate irregularly. Primaries originate on the umbilical wall or at the umbilical shoulder, are flexuous across the flanks and bend toward the apertural zone in the third portion of flanks closer to venter to form small clavi on ventro-lateral angles. One 
or two intercalated secondary ribs originate at various levels on flanks and are usually less prominent than the adjoining primaries. Ribs missing or greatly attenuated across venter on half portion of last whorl closer to protoconch, but they are transverse and fairly prominent across venter on the half portion of last whorl closer to the apertural zone. Ribs much narrower than interspaces.

The following are the dimensions of the holotype and Humphrey's hypotype:

$\begin{array}{cccc}\begin{array}{c}\text { Total } \\ \text { diameter }\end{array} & \begin{array}{c}\text { Last Whorl } \\ \text { height }\end{array} & \begin{array}{c}\text { Last Whorl } \\ \text { width }\end{array} & \begin{array}{c}\text { Diameter } \\ \text { of umbilicus }\end{array} \\ 65 \mathrm{~mm} & 27.6 \mathrm{~mm} & 18.7 \mathrm{~mm} & 21.5 \mathrm{~mm} \\ 46 ? \mathrm{~mm} & 18.6 \mathrm{~mm} & 11 \mathrm{~mm} & 18 ? \mathrm{~mm}\end{array}$

Dimensions of representative specimens of Dufrenoyia scotti from Presa Francisco Zarco

$\begin{array}{lcccr} & \begin{array}{c}\text { Total } \\ \text { diameter }\end{array} & \begin{array}{c}\text { Last Whorl } \\ \text { height }\end{array} & \begin{array}{c}\text { Last Whorl } \\ \text { width }\end{array} & \begin{array}{c}\text { Diameter } \\ \text { of umbilicus }\end{array} \\ \text { Specimen PFZ-0112 } & 72.15 \mathrm{~mm} & 29.84 \mathrm{~mm} & 6.15 \mathrm{~mm} & 24.18 \mathrm{~mm} \\ \text { Specimen PFZ-0122 } & 39 \mathrm{~mm} & 14.18 \mathrm{~mm} & 2.66 \mathrm{~mm} & 13.25 \mathrm{~mm} \\ \text { Specimen PFZ-0127 } & 39.15 \mathrm{~mm} & 12.28 \mathrm{~mm} & --- & 11.75 \mathrm{~mm} \\ \text { Specimen PFZ-0182 } & 33.22 \mathrm{~mm} & 13.46 \mathrm{~mm} & 2.22 \mathrm{~mm} & 12.25 \mathrm{~mm} \\ \text { Specimen PFZ-0192 } & 35 ? & 11.12 \mathrm{~mm} & 2.95 \mathrm{~mm} & 10.07 \mathrm{~mm}\end{array}$

\section{Remarks:}

Humphrey (1949) proposed this species from a Mexican specimen of the La Peña Formation at Sierra de Los Muertos, Coahuila as well as one specimen from Webster Parish, Louisiana, USA, which had been previously identified by Scott (1940a) as 
Dufrenoya aff. dufrenoyi. The latter specimen was made available to him through the Bureau of Economic Geology of the University of Texas at Austin. The finer and more widely spaced ribs on the flanks, and their attenuation across the venter are the striking characteristics that easily differentiate Dufrenoyia scotti from the other species of the genus Dufrenoyia. Thirty eight fairly well preserved specimens of this taxon were collected at stratigraphic levels 93,96,97, 101, and 104, within the lower part of the La Peña Formation at Francisco Zarco. The species ranges from the upper part of the lower Aptian Dufrenoyia justinae Zone, into the lower part of the middle Aptian Burckhardites nazasensis/Rhytidoplites robertsi Zone (Figure 11 , in pocket). This species occurs concurrently with $D$. dufrenoyi in the upper part of the stratigraphic range of $D$. justinae (Figure 11, in pocket) and within microfacies zone I of the Francisco Zarco section (Figure 7), therefore, the sedimentological aspects of the beds from which specimens of $D$. scotti were sampled, are the same as those discussed in the remarks of D. justinae.

\section{Occurrence:}

This species has been reported from the lower part of the Lower Glen Rose Formation in Webster Parish, Louisiana, USA (Scott, 1940a), from the lower part of the La Peña Formation at Cañon de San Antonio, Sierra de Los Muertos, Coahuila, Mexico (Humphrey, 1949), and from the lower part of the La Peña Formation at the Presa Francisco Zarco section in Sierra del Rosario, Durango, Mexico (this study). Specimens studied from Presa Francisco Zarco are identical to those figured by the previous authors, which implies that they show significant morphologic uniformity over a broad geographic range within the eastem Gulf coast region. 
Family (?) Parahoplitidae Spath, 1922

Subfamily Acanthohoplitinae Stoyanow, 1949

\author{
Genus Acanthohoplites Sinzow, 1907 \\ Type species. Parahoplites aschiltaensis Anthula, 1899, p. 117
}

Acanthohoplites acutecosta Riedel, 1938

(Plate 56, Figs. 6-9)

Parahoplites sp. Burckhardt, 1925, p. 23, Plate 4, Figs. 19-23.

Acanthohoplites acutecosta Riedel, 1938, p. 42-43, Plate 8, Figs. 1-6.

Acanthohoplites aff. acutecosta Riedel, 1938: Contreras-Montero, 1977, p. 15, Plate V, Fig. 4.

\title{
Description:
}

The following description is modified from the original description given in Spanish by Riedel (1938, pp. 42-43):

Shell discoidal and semi-evolute with last whorl embracing about one-fourth of preceding whorl. Whorl section subovoidal. Umbilical region wide, occupying about two thirds of total diameter of shell, moderately deep with an umbilical wall steep in small specimens, and more inclined in larger specimens; umbilical shoulder rounded in young whorls, and gently convex on half of shell closer to the apertural zone. Venter truncated and excavated in early stages, becoming squarish and convex with growth. Omamentation consists of strong primary ribs which originate in the umbilical region and are raised and acute across the flanks. These primary ribs may bifurcate in the part of the flanks closest to venter. Between the primary ribs, there are thinner intercalated secondary ribs which originate mostly in the third portion of the flank closer to venter, and occasionally in the middle of 
the flanks. In rare cases these secondary ribs originate in the umbilical region.

Dimensions of the holotype are not given by Burckhardt or Riedel.

Dimensions of representative specimens of Acanthohoplites acutecosta from Presa Francisco Zarco

$\begin{array}{cccc}\text { Total } & \text { Last Whorl } & \text { Last Whorl } & \text { Diameter } \\ \text { diameter } & \text { height } & \text { width } & \text { of umbilicus }\end{array}$

Specimen PFZ-0314 $23.89 \mathrm{~mm}$

$9.12 \mathrm{~mm}$

$9.12 \mathrm{~mm}$

Specimen PFZ-0319

$12.85 \mathrm{~mm}$

$5.47 \mathrm{~mm}$

$11.26 \mathrm{~mm}$

Specimen PFZ-0208

$14.18 \mathrm{~mm}$

$4.29 \mathrm{~mm}$

Specimen PFZ-0324

$13.42 \mathrm{~mm}$

\section{Remarks:}

This species was proposed by Riedel (1938) to include specimens from Durango, Mexico reported by Burckhardt (1925) as Parahoplites sp., and some specimens that he collected in Colombia. Acanthohoplites acutecosta Riedel, differs from the other species of the genus by the remarkable apparent trifurcation of the ribs because the secondary ribs mostly originate on the third portion of flanks closer to the ventral region, and very close to the bifurcating primaries. This specific distinguishing feature of the species was observed in seven well-preserved specimens found at levels $108,112,113 \mathrm{~b}, 113 \mathrm{c}, 122$ and 125 of the Francisco Zarco section (Figure 11, in pocket). The stratigraphic levels where it occurs in the Burckhardtites nazasensis/Rhytidoplites robertsi Zone (Figure 11, in pocket) are coincident with a rich ammonite assemblage characterized by the absence of the genus Dufrenoyia, and the relative abundance of specimens of Rhytidoplites robentsi Scott. Furthermore, these stratigraphic levels fall within the middle part of microfacies zone $I$ (Figure 7) in which the organic carbon content of the rocks oscillate below $1 \%$ (Appendix 2, Fig. 9-c). 


\section{Occurrence:}

Acanthohoplites acutecosta Riedel has been reported to occur in the lower part of the La Peria Formation at Nazas, Durango (Burckhardt, 1925; and this study), at Minillas and La Boca Canyon (this study), Nuevo Leon (Contreras Montero, 1977) in northeastern Mexico; and in Aptian rocks from the "Cordillera Oriental" in the central part of Colombia (Riedel, 1938).

Acanthohoplites aschiltaensis (Anthula, 1900)

(Plate 56, Figs. 10-16)

Parahoplites aschiltaensis Anthula, 1900, p. 117, Plate X (IX), Figs. 2 a-b, 3 a-b; Plate XI (X), Fig. 1.

Acanthohoplites aschiltaensis (Anthula, 1900): Sinzow, 1908, pp. 478-480, Plate VI, Fig. 19.

Acanthohoplites aff. aschiltaensis (Anthula, 1900): Cantu A., 1963, p. 46, PI. V, Fig. 2d. Acanthohoplites aschiltaensis (Anthula, 1900): Contreras Montero, 1977, p. 15, Plate V, Figs. 1-3; Plate VI, Fig. 4.

\section{Description:}

The following description is modified from the original description given in German by Anthula $(1900$, p. 117), and later emendation to the general ornamentation pattem described in French by Cantu (1963, p. 46):

Shell discoidal, semi-evolute, with last whorl embracing about one-fourth of preceding whorl. Flanks flattened and increasing slowly in height with size. Whorl section subovoidal twice as high as wide. Umbilicus wide, occupying about half of the total diameter of the shell; umbilical wall inclined without a defined edge; umbilical shoulder rounded. Venter truncated, squarish and widely convex in larger specimens. Omamentation 
consists of simple primary and widely spaced ribs. All ribs show a low relief, and they are either straight or slightly sinuous. All primary ribs originate on the umbilical edge and widen in the third portion of flanks closer to venter. The part of the last whorl that is the closest to the apertural zone displays two or three ribs that develop a slight tuberculiform protuberance toward the middle of the flanks. Secondary ribs are present alternating with the primaries only in the part of the last whorl closer to the protoconch. They originate in the middle of the flanks and are less curved than the primaries. In addition, two small ribs develop separately on the third portion of the flank closer to the venter towards the youngest part of the external whorl.

Dimensions of the two specimens reported by Anthula in 1900 are as follows:

$\begin{array}{lcccc} & \begin{array}{c}\text { Total } \\ \text { diameter }\end{array} & \begin{array}{c}\text { Last Whorl } \\ \text { height }\end{array} & \begin{array}{c}\text { Last Whorl } \\ \text { width }\end{array} & \begin{array}{c}\text { Diameter } \\ \text { of umbilicus }\end{array} \\ \text { Specimen 1 } & 70 \mathrm{~mm} & 30 \mathrm{~mm} & 25 \mathrm{~mm} & 23 \mathrm{~mm} \\ \text { Specimen 2 } & 45 \mathrm{~mm} & 18 \mathrm{~mm} & 17 \mathrm{~mm} & 16 \mathrm{~mm}\end{array}$

Dimensions of representative specimens of Acanthohoplites aschiltaensis from Presa Francisco Zarco (PFZ) and La Boca Canyon (LBC)

$\begin{array}{ccccc} & \begin{array}{c}\text { Total } \\ \text { diameter }\end{array} & \begin{array}{c}\text { Last Whorl } \\ \text { height }\end{array} & \begin{array}{c}\text { Last Whorl } \\ \text { width }\end{array} & \begin{array}{c}\text { Diameter } \\ \text { of umbilicus }\end{array} \\ \text { Specimen PFZ-0339 } & 19.83 \mathrm{~mm} & 8.16 \mathrm{~mm} & -\cdots & 8.39 \mathrm{~mm} \\ \text { Specimen PFZ-0309 } & 22.18 \mathrm{~mm} & 9.25 \mathrm{~mm} & -1.35 \mathrm{~mm} \\ \text { Specimen PFZ-0344 } & 32.15 ? \mathrm{~mm} & 12.14 \mathrm{~mm} & 8.09 \mathrm{~mm} & 10.77 \mathrm{~mm} \\ \text { Specimen PFZ-0354 } & 33.55 ? \mathrm{~mm} & 13.34 \mathrm{~mm} & 11.16 \mathrm{~mm} & 13.85 ? \mathrm{~mm} \\ \text { Specimen PFZ-0120 } & 27.07 \mathrm{~mm} & 10.25 \mathrm{~mm} & 7.92 \mathrm{~mm} & 9.44 \mathrm{~mm}\end{array}$


Specimen LBC-0143

Specimen LBC-0200
$50.13 \mathrm{~mm}$

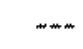

$11.18 \mathrm{~mm}$

$23.72 \mathrm{~mm}$ $+\cdots$

$9.25 \mathrm{~mm}$

$12.34 \mathrm{~mm}$

\section{Remarks:}

Acanthohoplites aschiltaensis was originally classifłed by Anthula (1900) under the genus Parahoplites based on observations of specimens collected from the Caucasus region. Acanthohoplites aschiltaensis can be easily recognized from $A$. acutecosta by its more separated primary ribs which do not bifurcate. As noted by Cantu (1963), this species shows much affinities to specimen of Dufrenoyia, but all species of this genus generally show more flexuous and undulating ribs than those displayed by the specimens of $A$. aschiltaensis. Nineteen specimens collected within the middle Aptian Burckhardtites nazasensis/Rhytidoplites robertsi and the upper Aptian Cheloniceras inconstans Zones at stratigraphic levels 108,110,112,113,125,129,132 and 136b (Figure 11, in pocket) of the La Peña Formation from the Francisco Zarco section were assigned to this species. All the specimens are morphologically similar to those identified as Parahoplites aschiltaensis by Anthula (1900). This species was found in association with specimens of $A$. acutecosta at stratigraphic levels $108,112,113 \mathrm{~b}$ and 125 , within microfacies zone I (Figure 7). It is remarkable that specimens of Acanthohoplites aschiltaensis are also found at stratigraphic levels 110,113,129, and 132 of the Francisco Zarco section (Figure 11, in pocket), but $A$. acutecosta is absent, although there is no apparent factor recorded in the sediment that could have precluded its presence. At La Boca Canyon, twelve specimens of this species were found at stratigraphic levels $\mathrm{K}-2, \mathrm{~K}-7$, and $\mathrm{K}-9$ (Figure 6).

\section{Occurrence:}

Acanthohoplites aschiltaensis has been reported to occur in the Caucasus region (Anthula, 1900; Sinzow, 1908), and from beds of the La Peña Formation of northeastern Mexico in 
the States of Coahuila (Cantu, 1963), Nuevo Leon (Contreras-Montero, 1977), and Durango (this study). In general, there are no morphological differences between the Mexican specimens and those reported from the Caucasus region that could indicate geographic variations of the species.

Acanthohoplites potreritensis Humphrey, 1949

(Plate 57, Figs. 1-2)

Acanthoplites potreritensis Humphrey, 1949, p. 139, Plate 12, Figs. 11-12.

Acanthohoplites potreritensis Wright et al., 1996, p. 275, Fig. 215, 2 a-c.

\section{Description:}

This description is based on modifications of Humphrey's (1949) original description of the species:

Form discoidal; evolute, with last whorl embracing about one-fourth of preceding whorls. Whorl section subovoidal, nearly as wide as high. Umbilicus moderately wide, occupying about half of the total diameter of shell; umbilical wall steep; umbilical shoulder sharply rounded. Venter truncated, becoming squarish and widely convex toward the apertural zone. Onamentation characterized by irregularly alternating primary and secondary ribs. Primaries begin well down on umbilical wall, flare out strongly with considerable relief on the two thirds of flanks closer to dorsum, then decrease rapidly in prominence, either bifurcating or simple forming an elongate node on the third portion of flanks closer to venter. All ribs slightly attenuated and excavated along midline of venter which they cross transversely. Primary ribs may be flexed weakly toward the apertural zone or may be radial on the half of the flank closer to the dorsum.

Holotype dimensions: 
Total diameter: $38 \mathrm{~mm}$, Last whorl height: 14 ? $\mathrm{mm}$, Last whorl width: 10 ? $\mathrm{mm}$, Diameter of umbilicus: $15 \mathrm{~mm}$.

Dimensions of representative specimens of Acanthoplites potreritensis from Presa Francisco Zarco

\begin{tabular}{|c|c|c|}
\hline $\begin{array}{l}\text { Total } \\
\text { diameter }\end{array}$ & $\begin{array}{c}\text { Last Whorl } \\
\text { height }\end{array}$ & $\begin{array}{l}\text { Last Whorl } \\
\text { width }\end{array}$ \\
\hline
\end{tabular}

Specimen PFZ $0304 \quad 21.30 \mathrm{~mm} \quad 7.90 \mathrm{~mm} \quad \ldots \quad 8.77 \mathrm{~mm}$

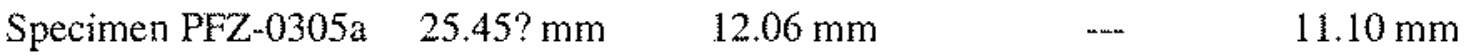

\section{Remarks:}

Acanthohoplites potreritensis was described by Humphrey (1949) based on a single specimen from Sierra de Los Muertos area in Coahuila State, northeastern Mexico. As discussed by Humphrey (1949, p. 139), this species can be easily distinguished from the other species of the genus by the prominent flaring of the primary ribs on the half of the flanks closer to dorsum. Omamentation of this taxon resembles that of Acanthohoplites acutecosta Riedel, but the latter species shows regular altemation of simple ribs between the bifurcating ones, whereas A potreritensis Humphrey shows a clear continuous bifurcation of the primary ribs. These characteristics were observed on three well-preserved specimens of this species collected at stratigraphic level 110 (Figure 11, in pocket). This stratigraphic level is a marly limestone within the middle part of microfacies zone I (Figure 7), and contains $0.66 \%$ of total organic carbon (Appendix 2, Figure 9-c).

\section{Occurrence:}

Acanthohoplites potreritensis has been found only in the La Peña Formation in Mexico, from the locality of Rincon de Los Potreritos, Sierra del Caporal in Coahuila State 
(Humphrey, 1949), and at the Presa Francisco Zarco section, in Durango State (this work), of northeastern Mexico. Its limited occurrence in Mexico suggests that it may be an endemic species of that area.

\section{Genus Colombiceras Spath, 1923}

Type species. Ammonites crassicostatus D'Orbigny, 1840, p. 197.

Colombiceras spathi Humphrey, 1949

(Plate 57, Figs. 3-10)

Colombiceras spathi Humphrey, 1949, pp. 151-152, Plate 18, Figs. 7-8. Colombiceras sp., Cantu, 1976, Plate 1, Figs. 8-8a.

\section{Description:}

The following description is modified after Humphrey's (1949) original description of the species:

Shell discoidal; compressed and moderately evolute; with last whorl embracing about onefourth of preceding whorls. Flanks convex. Venter narrow and flattened. Whor section subquadrate higher than wide. Umbilicus wide for genus, occupying about half of the total diameter of shell; umbilical wall steep and umbilical shoulder strongly rounded. Ornamentation consists of irregularly alternating primary and secondary ribs. Primaries rise on umbilical wall, quickly gain in prominence on umbilical shoulder and pass radially or very slightly flexuous across flanks, widening rapidly toward venter. On half portion of last whorl closer to protoconch, several primaries bifurcate on the third portion of flanks closer to dorsum or from tubercle-like swellings on umbilical shoulder. Two or more primaries may follow each other or alternate with single secondaries. The secondary ribs 
originate over the third portion of flanks closer to dorsum, and may simulate bifurcation by rising very close to an adjoining primary rib near umbilical area. On the half portion of last whorl closer to the apertural zone, there is rather a regular altemation of simple primaries and quite long secondary ribs. On the third portion of the flanks closer to venter, all ribs present typical flat-topped, steep-sided appearance characteristic of the genus. Ribs are widest and have most relief on venter, where they are evenly spaced, equal in size, and transverse.

Holotype dimensions:

Total diameter: $50 \mathrm{~mm}$, Last whorl height: $19 \mathrm{~mm}$, Last whorl thickness: 11 ? $\mathrm{mm}$, Diameter of umbilicus: $18 \mathrm{~mm}$.

Dimensions of representative specimens of Colombiceras spathi from Presa Francisco Zarco (PFZ) and La Boca Canyon (LBC)

$\begin{array}{cccc}\text { Total } & \text { Last Whorl } & \text { Last Whorl } & \text { Diameter } \\ \text { diameter } & \text { height } & \text { width } & \text { of umbilicus }\end{array}$

Specimen PFZ 0346

--- $\quad 20.10 \mathrm{~mm}$

$5.88 \mathrm{~mm}$

Specimen PFZ-0210a $50.67 \mathrm{~mm}$

$16.92 \mathrm{~mm}$

$4.67 \mathrm{~mm}$

$22.03 \mathrm{~mm}$

Specimen PFZ-0210b $50.86 \mathrm{~mm}$

$17.35 \mathrm{~mm}$

$18.89 \mathrm{~mm}$

Specimen PFZ-0225

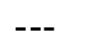

$16.38 \mathrm{~mm}$

$4.68 \mathrm{~mm}$

Specimen PFZ-0230

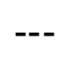

$8.41 \mathrm{~mm}$

Specimen PFZ-0137b

$19.76 \mathrm{~mm}$

$7.65 \mathrm{~mm}$

$7.06 \mathrm{~mm}$

Specimen LBC-0083

$8.12 \mathrm{~mm}$ 


\section{Remarks:}

Humphrey $(1949$, p. 51$)$ described Colombiceras spathi based on observations made on a single tectonically-distorted specimen from Coahuila State, northeastern Mexico. As discussed by Humphrey $(1949$, p. 151), Colonbiceras spathi is morphologically similar to Colombiceras subtobleri (Kasansky) from Daghestan, Northern Caucasus of the western Caspian Sea region. The main difference is that $C$. subtobleri is more involute and the bifurcation of its primary ribs takes place in the third portion of the flanks closer to the venter, whereas in C. spathi the bifurcation occurs on the third portion of the flanks closer to dorsum. Ten specimens assigned to this species were found at stratigraphic level 93 within the lower Aptian Dufrenoyia justinae Zone of the La Peña Formation at Francisco Zarco (Figure 11, in pocket). All the specimens are morphologically similar to the one illustrated by Humphrey (1949, pp. 151-152, Plate 18, Figs. 7 8). Level 93 is the only stratigraphic record of this species within the Francisco Zarco section, and as previously discussed in the remarks of Paracymatoceras milleri, this level belongs in the lower part of microfacies zone I of the La Peña Formation (Figure 7), which is one of the intervals richest in ammonites, and its total organic carbon is $1.94 \%$ (Appendix 2, Fig. 9-a).

\section{Occurrence:}

Colombiceras spathi Humphrey can be considered an endemic species to northeastern Mexico, because until now it has not been reported elsewhere. Recorded occurrences in the La Peña Formation of northeastern Mexico include following localities: Rincon de los Potreritos, Sierra del Caporal in Coahuila State; La Huasteca Canyon in Nuevo Leon State; and Presa Francisco Zarco in Durango State (this work). 
Genus Hypacanthoplites Spath, 1923

Type species. Acanthoceras milletianum (d'Orbigny) var. plesiotypica Fritel, 1906, p. 245 .

Hypacanthoplites cf. leanzae Humphrey, 1949

(Plate 57, Figs. 11-16)

Hypacanthoplites leanzae Humphrey, 1949, pp. 141-142, Plate 13, Figs. 7-9.

\section{Description:}

The following description is modified from the original description given by Humphrey in 1949.

Shell discoidal, semi-evolute with last whorl embracing about one-third of preceding whorls. Whorl section subovoidal, higher than wide. Flanks and venter convex. Umbilicus occupies about half of the total diameter of shell; umbilical wall almost perpendicular with respect to flanks; umbilical shoulder strongly rounded. Omamentation consists of strong primary ribs and occasionally altemating secondary ribs. Primaries originate on umbilical wall and are slightly swollen at umbilical shoulder. They cross the flanks radially or are slightly flexuous, with a tendency to form second row of tubercles at about the mid flank. Primaries become less prominent and are transverse or only weakly curved toward the apertural zone across venter where all ribs are equal in size on third portion of flanks closer to venter. Secondary ribs originate at mid flanks. All ribs equally spaced on venter and somewhat narrower than interspaces.

Holotype dimensions:

Total diameter: $60 \mathrm{~mm}$, Last whorl height: $28 \mathrm{~mm}$, Last whorl width: $23 \mathrm{~mm}$, Diameter of umbilicus: $22 \mathrm{~mm}$. 
Dimensions of representative specimens of Hypacanthoplites leanzae from Presa Francisco Zarco

$\begin{array}{lcccc} & \begin{array}{c}\text { Total } \\ \text { diameter }\end{array} & \begin{array}{c}\text { Last Whorl } \\ \text { height }\end{array} & \begin{array}{c}\text { Last Whorl } \\ \text { width }\end{array} & \begin{array}{c}\text { Diameter } \\ \text { of umbilicus }\end{array} \\ \text { Specimen PFZ-0175 } & 39.15 ? \mathrm{~mm} & 14.63 \mathrm{~mm} & 9.35 \mathrm{~mm} & 18.28 ? \mathrm{~mm} \\ \text { Specimen PFZ-0180 } & --- & 18.19 \mathrm{~mm} & --- & -\cdots \\ \text { Specimen PFZ-0185 } & 31.47 \mathrm{~mm} & 12.69 \mathrm{~mm} & 5.46 \mathrm{~mm} & 14.64 \mathrm{~mm} \\ \text { Specimen PFZ-0190 } & --- & 12.07 \mathrm{~mm} & --- & \ldots \\ \text { Specimen PFZ-0195 } & --- & 14.22 \mathrm{~mm} & -- & \\ \text { Specimen PFZ-0205 } & 40.17 \mathrm{~mm} & 18.84 \mathrm{~mm} & --- & 19.67 \mathrm{~mm}\end{array}$

\section{Remarks:}

Hypacanthoplites leanzae was described by Humphrey (1949) from observation based on a single specimen collected in Coahuila State, northeastern Mexico. Twenty three specimens conferred to this species were collected at stratigraphic levels $140 \mathrm{~b}, 142 \mathrm{a}, 144 \mathrm{a}, 150,156$, $173 \mathrm{~b}, 183 \mathrm{a}, 189 \mathrm{~b}$ and $190 \mathrm{~d}$ (Figure 11, in pocket), of the La Peña Formation at Francisco Zarco. The specimens conferred to Hypacanthoplites leanzae are morphologically very similar to the specimen illustrated by Humphrey (1949, Plate 13, Figs. 7-9), except that the holotype has two and three secondary ribs between the adjoining primaries, whereas specimens conferred to this species in the present work display one occasional secondary rib intercalated between two primaries. Given the importance of the secondary ribs as characteristics of the species (Humphrey, 1949), assignment of the specimens from Francisco Zarco to Hypacanthoplites leanzae remains conjectural. Perhaps the number of intercalated secondary ribs between primaries is truly variable in the species, as observed in 
the 23 specimens studied, but it is evident that the single specimen used to describe the species could not have provided such intraspecific variation.

Hypacanthoplites leanzae is the last species of ammonite recorded in the stratigraphic sequence at Francisco Zarco, and its total stratigraphic record is the characteristic of the upper Aptian Hypacanthoplites cf. leanzae Zone of that formation (Figure 11, in pocket). The stratigraphic levels where specimens of this taxon were collected belong in the upper part of microfacies zone I and mosi of microfacies zone 3 of the La Peña Formation (Figure 7). This interval is characterized by a relatively high organic carbon content that varies between 0.16 and $15.21 \%$ (Appendix 2, Figure 9-c).

\section{Occurrence:}

Hypacanthoplites leanzae has been found only in the La Peña Formation of northeastern Mexico. It has been reported at Rincon de Las Vallas, Coahuila State (Humphrey, 1949), and at Presa Francisco Zarco, Sierra del Rosario, in Durango State (this work). Its limited occurrence in Mexico suggests that it may be endemic to that area.

\section{Genus Penaceras Cantu, 1963}

Type species. Hypacanthoplites? rursiradiatus Humphrey, 1949, p. 142.

Penaceras rursiradiatus (Humphrey, 1949)

(Plate 58, Figs. 1-3)

Hypacanthoplites? rursiradiatus Humphrey, 1949, p. 142, Plate 14, Figs. 11.12.

Peñaceras rursiradiatus (Humphrey, 1949): Cantu, 1963, pp. 54-55.

Pegnaceras rursiradiatus (Humphrey, 1949): Etayo Serna, 1979, p. 55.

Penaceras rursiradiatus (Humphrey, 1949); Wright et al., 1996, p. 275. 


\section{Description:}

The following description is modified from Humphrey's (1949) original description, and later emendation of the omamentation pattern discussed by Cantu (1963) with designation of the genus:

Shell discoidal; semi-evolute, with last whorl embracing about a quarter of preceding whorls. Flanks flattened. Whorl section subovoidal, a little higher than wide. Venter flattened. Umbilicus occupies about one-third of total diameter; umbilical wall steep; umbilical shoulder rounded. Omamentation consists of equally spaced, regularly altemating, primary and secondary ribs. Rarely, two primaries or two secondaries may follow. A marked curving of the ribs toward the protoconch on the half portion of flanks closer to venter, and across ventral area is characteristic. Primary ribs originate on umbilical wall, thicken rapidly on umbilical shoulder, and maintain their strength across the flanks, forming transverse swellings on the ventro-lateral margins. Secondary ribs originate from interspaces at mid flanks, or occasionally at third portion of flanks closer to venter, and are equal to primaries on ventro-lateral border where all ribs thicken. Across mid line of venter, ribs are straight and equally spaced.

Holotype dimensions:

Total diameter: $58.6 \mathrm{~mm}$, Last whorl height: $21 \mathrm{~mm}$, Last whorl width: $19.4 \mathrm{~mm}$, Diameter of umbilicus: $26.8 \mathrm{~mm}$.

Dimensions of representative specimens of Penaceras nursiradiatus from Presa Francisco Zarco (PFZ) and La Boca Canyon (LBC)

$\begin{array}{lccc}\text { Total } & \text { Last Whorl } & \text { Last Whorl } & \text { Diameter } \\ \text { diameter } & \text { height } & \text { width } & \text { of umbilicus }\end{array}$

Specimen PFZ-0299 $\quad 53.70 \mathrm{~mm} \quad 22.18 \mathrm{~mm} \quad 20.25 \mathrm{~mm}$

Specimen PFZ-0248 $\quad 47.03 \mathrm{~mm} \quad 17.55 \mathrm{~mm} \quad 15.33 \mathrm{~mm}$




\section{Remarks:}

Penaceras nursiradiatus was originally described by Humphrey (1949) as Hypacanthoplites? rursiradiatus based on observations made on one specimen from the La Peña Formation in Coahuila State, northeastern Mexico. Humphrey (1949, p. 142), assigned the specimen to Hypacanthoplites with some degree of doubt because of the flattened venter and transwerse swellings of the ribs on the ventromateral margins, characters that are not diagnostic of the genus. The issue of morphological differences with Hypacanthoplites was raised by Cantu (1963) who pointed out the marked curving of the ribs toward the protoconch on the half portion of flanks closer to venter, and across ventral area, characteristic that also gives the name of the type species. Hence, Cantu proposed the new genus Peñaceras as a substitute name for Hypacanthoplites. Further emendations of the genus name as Pegnaceras and Penaceras, were introduced by Etayo Serna (1979), and Wright et al. (1996), respectively. Three specimens found at stratigraphic levels 108 and 112 within the middle Aptian Burckhardtites nazasensis/Rhytidoplites robertsi Zone (Fig. 11, in pocket) of the La Peña Formation at Francisco Zarco are assigned to Penaceras rursiradiatus. All the specimens are morphologically similar with the one identified as Hypacanthoplites? nursiradiatus by Humphrey (1949). At stratigraphic level 108 of the Francisco Zarco section, $P$. nirsiradiatus is in association with a rich assemblage of ammonites from different genera such as Acanthoplites, Rhytidoplites, Parahoplites, Cheloniceras, and Colombiceras (Figure 11, in pocket). At stratigraphic level 112, in addition to these taxa, $P$. rursiradiatus is also found associated with Peltocrioceras(?) sp., Acrioceras (Epacrioceras) sp., Kazanskyella cf. arizonica, and Tropaeum (Ancylotropaeum) sp., which occur only in that single bed at Francisco Zarco. Both stratigraphic levels correspond to microfacies zone I in the lower part of the La Peña 
Formation (Figure 7). This microfacies zone is characterized by black marly biocalcilutites with abundant planktonic foraminifera, common ostracods, and echinoid fragments altemating with marly soft horizons, but level PFZ-112 is a micritic mudstone in which all these allochems are absent and terrigenous materials are common. Total organic carbon at stratigraphic horizons 108 and 112 are $0.18 \%$ and $0.12 \%$ respectively (Appendix 2 , Figure 9-c).

\section{Occurrence:}

Penaceras nursiradiatus has been found only in Mexico at Rincón de los Potreritos, in Couahuila State (Humphrey, 1949), and at the section at Presa Francisco Zarco, in Durango State (this work). There is not apparent morphological differences between the specimens from the two geographic areas.

\section{Genus Rhytidoplites Scott, 1940}

Type species. Rhytidoplites robertsi Scott, 1940, pp. 1035-1037

\section{Rhytidoplites robertsi Scott, 1940}

(Plate 58, Figs. 4-13)

Rhytidoplites robertsi Scott, 1940a, pp. 1035-1037, Plate 61, Fig. 11; Plate 63, Fig. 7

Rhytidoplites robertsi Scott, 1940a: Cantu, 1976, p. 15, Plate I, Figs. 4-4a, 6-6a.

Rhytidoplites robentsi Scott, 1940a: Contreras-Montero, 1977, pp. 14-15, Plate VI, Figs. $2-3$.

\section{Description:}

The following description is modified from the original description given by Scott (1940a, pp. 1035-1037): 
Shell discoidal; semi-evolute, with last whorl embracing about half of preceding whorls. Whorl section sub-rectangular with whorls higher than wide and with thickest portion near the umbilical border. Flanks flattened, converging toward the almost flat venter. Umbilicus occupying about one third of total diameter. Umbilical shoulder rounded, and umbilical wall perpendicular with respect to flanks. Omamentation consists of numerous narrow and rounded primary ribs which originate either on umbilical wall, or as bundles from prominent and elongated tubercles. Near the middle of the flanks they flex gently toward the protoconch and cross the venter without interruption. Intercalated secondary ribs originate on the middle of the flanks, and across the venter, they are indistinguishable from the primaries.

Holotype dimensions:

Total diameter: $63 \mathrm{~mm}$, Last whorl height: $30 \mathrm{~mm}$, Last whorl width: $17 \mathrm{~mm}$, Diameter of umbilicus: $17 \mathrm{~mm}$.

Dimensions of representative specimens of Rhytidoplites robertsi from Presa Francisco Zarco (PFZ) and La Boca Canyon (LBC)

$\begin{array}{cccc}\begin{array}{c}\text { Total } \\ \text { diameter }\end{array} & \begin{array}{c}\text { Last Whorl } \\ \text { height }\end{array} & \begin{array}{c}\text { Last Whorl } \\ \text { width }\end{array} & \begin{array}{c}\text { Diameter } \\ \text { of umbilicus }\end{array} \\ \cdots & 11.92 \mathrm{~mm} & 3.27 \mathrm{~mm} & \ldots \\ \cdots & 9.82 \mathrm{~mm} & 2.78 \mathrm{~mm} & \\ \cdots & 11.82 \mathrm{~mm} & 3.11 \mathrm{~mm} & \cdots \\ & 11.87 \mathrm{~mm} & 3.15 \mathrm{~mm} & \cdots \\ 28.27 \mathrm{~mm} & 12.65 \mathrm{~mm} & 3.76 \mathrm{~mm} & 8.82 \mathrm{~mm} \\ 30.13 \mathrm{~mm} & 10.25 \mathrm{~mm} & 3.81 \mathrm{~mm} & 10.12 \mathrm{~mm} \\ 38.56 \mathrm{~mm} & 13.84 \mathrm{~mm} & 4.23 \mathrm{~mm} & 13.02 \mathrm{~mm}\end{array}$


Specimen LBC-0078a

$7.12 \mathrm{~mm}$

$3.28 \mathrm{~mm}$

Specimen LBC-0078b

$6.98 \mathrm{~mm}$

$3.03 \mathrm{~mm}$

Specimen LBC-0138

$8.34 \mathrm{~mm}$

$3.40 \mathrm{~mm}$

\section{Remarks:}

Scott (1940a) proposed Rhytidoplites robertsi as the type species of the new genus Rhytidoplites. The description of this new genus and their corresponding species (Scott, 1940a) was the result of his studies of ammonites from the Cretaceous Trinity Group in south-central United States. As discussed by Scott (1940a, p. 1034), the diagnostic characteristic of the genus Rhytidoplites is the arrangement of the ribs in bundles located on the umbilical margin, or in the dorsal area of the flanks. In the case of Rhytidoplites robertsi, these bundles assume the prominence of greatly elongated tubercles. These morphological characteristics were observed in 56 fairly well-preserved specimens, collected at stratigraphic levels 108,110,112,113, and 122 within the middle Aptian Burckhardtites nazasensis/Rhytidoplites robertsi Zone (Figure 11, in pocket) in the La Peña Formation at Francisco Zarco. These stratigraphic levels fall within microfacies zone I (Figure 7) where organic carbon content remains below $1 \%$ (Appendix 2, Figure 9-c).

\section{Occurrence:}

Rhytidoplites robertsi has been reported from the Blue marls of the Cuchillo Formation at the confluence of Mayfield Canyon and the Rio Grande in southwestern Texas, and from a deep well in Louisiana (Scott, 1940a). The presence of this taxon in notheastern Mexico has been reported from the La Peña Formation in the States of Nuevo Leon (Cantu, 1976; Contreras-Montero, 1977) and Durango (this work). 


\section{Subfamily Parahoplitinae Spath, 1922}

\section{Genus Kazanskyella Stoyanow, 1949}

Type species. Kazanskyella arizonica, Stoyanow, 1949, pp. 100-101.

\section{cf. Kazanskyella arizonica Stoyanow, 1949}

(Plate 58, Fig. 14)

Kazanskyella arizonica Stoyanow, 1949, pp. 100-101, Plate 17, Figs. 2-8.

Kazanskyella arizonica Stoyanow, 1949: Wright et al., 1996, p. 277, Fig. 216, 1 a-c.

\section{Description:}

The following description is modified from the original description given by Stoyanow (1949, p. 100-101), and on personal observation of a fragment of this taxon collected in the La Peña Formation at Francisco Zarco:

Shell moderately evolute, with last whorl embracing about one-third of preceding whorls. Whorl section rounded in the inner whorls, passes to oval as the slightly inflated flanks become flatter with size. The mature whorls attain an ovate section and show rapid increase of the ribs in size. Umbilicus narrow, occupying only about one-third of the total diameter; umbilical wall steep and umbilical shoulder rounded. Ornamentation on last whorl consists of uniformly radial coarse ribs slightly inclined toward the protoconch at the peripheral margin. One closely set secondary rib between two primanies is common. All ribs originate on the umbilical edge.

Ranges of dimensions of the four syntypes reported by Stoyanow are as follows:

Total diameter: $17-66 \mathrm{~mm}$, Last whorl height: $9-25 \mathrm{~mm}$, Last whorl width: $8.25 \mathrm{~mm}$, Diameter of umbilicus: $4-19 \mathrm{~mm}$. 
A single specimen of cf. Kazanskyella arizonica collected at level 112 of the Francisco Zarco section shows the following dimensions:

$\begin{array}{ccccc} & \begin{array}{c}\text { Total } \\ \text { diameter }\end{array} & \begin{array}{c}\text { Last whorl } \\ \text { height }\end{array} & \begin{array}{c}\text { Last whorl } \\ \text { width }\end{array} & \begin{array}{c}\text { Diameter } \\ \text { of umbilicus }\end{array} \\ \text { Specimen PFZ-0278 } & -- & 68.12 \mathrm{~mm} & 45.22 \mathrm{~mm} & 63.35 ? \mathrm{~mm}\end{array}$

\section{Remarks:}

The genus Kazanskyella was proposed by Stoyanow (1949, pp. 99-100) to include some ammonites from the Aptian of Daghestan, Caucasus, which were identified as Parahoplites melchioris Anthula by Kazansky (1914), as well as congeneric species he identified in the Lowell Formation of southeastern Arizona. As indicated by Stoyanow, "the examples figured by Kazansky disagree in the nature of ornamentation with Parahoplites melchioris Anthula, and with Parahoplites in general". Thus Stoyanow proposed two species names, $K$. daghestanica to include the Caucasus specimens, and $K$. arizonica to define the specimens from southeastern Arizona. An almost complete and well preserved fragment, compatible with the description of the latter taxon, was collected at stratigraphic level 112 in the La Peña Formation at Francisco Zarco.

Assignment of this fragment to Kazanskyella arizonica is based on morphological similarities with the specimen from Arizona identified by Stoyanow (1949), and also figured by Wright et al., (1996).

The only record of this taxon in the present work coincides with the same stratigraphic level (PFZ-112) which includes taxa of the Superfamily Ancylocerataceae, such as Peltocrioceras(?) $s p$. and Acrioceras (Epacrioceras) (?) $s p$ (Figure 11, in pocket). The faunal associations and facies characteristics of this stratigraphic horizon are discussed in the remarks of these taxa. 


\section{Occurrence:}

Kazanskyella arizonica has only been reported from the Lowell Formation of southeastem Arizona (Stoyanow, 1949), and from the La Peña Formation at Francisco Zarco in northeastern Mexico (this work).

\section{Genus Parahoplites Anthula, 1900}

Type species. Parahoplites melchioris, 1900, p. 111.

\section{Parahoplites mexicanus Humphrey, 1949}

(Plate 59, Figs. 1-11)

Parahoplites mexicanus Humphrey, 1949, p. 137, Plate 12, Figs. 7, 8.

\section{Description:}

The following description is modified from the original description given by Humphrey $(1949$, p. 137):

Shell moderately involute, with last whorl embracing about two-thirds of preceding whorls. Whorl section compressed. Flanks flattened. Umbilicus occupying about one-third of total diameter. Umbilical wall inclined and umbilical shoulder rounded. Venter flattened and slightly arched on half portion of outer whorl close to the apertural zone. Omamentation on the half portion of last whorl closer to the protoconch, consists of fine, irregularly alternating, simple primary and secondary ribs. Primary ribs originate on the umbilical wall and are flexuous and inclined toward the apertural zone across the flanks. Two or three primaries may follow. Secondary ribs originate on the umbilical shoulder and are equal to primaries on the third portion of flanks closer to ventral region and on venter, which all ribs cross unaltered. Ornamentation on the half portion of last whorl closer to the apertural zone is characterized by coarser and more widely spaced ribs. The altemation of 
ribs is more regular, consisting of one secondary intercalating between primaries and originating at the middle portion of the flank. Primary ribs may form small and elongate swellings on the umbilical margin.

Holotype dimensions:

Total diameter: $39 \mathrm{~mm}$, Last whorl height: $17.5 \mathrm{~mm}$, Last whorl width: $8.5 \mathrm{~mm}$, Diameter of umbilicus: $13.5 \mathrm{~mm}$.

Dimensions of representative specimens of Parahoplites mexicanus from Presa Francisco Zarco (PFZ) and La Boca Canyon ( $\mathrm{LBC})$

$\begin{array}{cccc}\text { Total } & \text { Last Whorl } & \text { Last Whorl } & \text { Diameter } \\ \text { diameter } & \text { height } & \text { width } & \text { of umbilicus }\end{array}$

$\begin{array}{lcccc}\text { Specimen PFZ-0219 } & 16.10 \mathrm{~mm} & 5.98 \mathrm{~mm} & --- & 5.32 \mathrm{~mm} \\ \text { Specimen PFZ-0224 } & 19.06 ? \mathrm{~mm} & 7.53 \mathrm{~mm} & --- & 6.86 ? \mathrm{~mm} \\ \text { Specimen PFZ-0234 } & --- & 8.92 \mathrm{~mm} & --- & --- \\ \text { Specimen PFZ-0239 } & 22.04 \mathrm{~mm} & 7.95 \mathrm{~mm} & 3.70 \mathrm{~mm} & 7.65 \mathrm{~mm} \\ \text { Specimen PFZ-0249 } & 22.23 \mathrm{~mm} & 9.33 \mathrm{~mm} & --- & 6.87 ? \mathrm{~mm} \\ \text { Specimen PFZ-0254 } & 14.12 ? \mathrm{~mm} & 5.18 \mathrm{~mm} & --- & 5.29 \mathrm{~mm} \\ \text { Specimen PFZ-0259 } & 23.16 ? \mathrm{~mm} & 11.85 \mathrm{~mm} & 3.29 \mathrm{~mm} & 8.37 ? \mathrm{~mm} \\ \text { Specimen PFZ-0264 } & --- & 6.70 \mathrm{~mm} & 6.54 \mathrm{~mm} & 5.16 ? \mathrm{~mm} \\ \text { Specimen PFZ-0274 } & --- & 5.73 \mathrm{~mm} & --- & -\ldots+\cdots \\ \text { Specimen LBC-0080 } & 11.90 \mathrm{~mm} & 6.02 \mathrm{~mm} & 4.98 \mathrm{~mm} & 5 \mathrm{~mm}\end{array}$

\section{Remarks:}

Assignment of twenty specimens collected at Presa Francis Zarco to Parahoplites mexicanus is based on comparison with Humphrey's work from the Rincon de Los 
Potreritos, Sierra de Los Muertos, in the State of Coahuila, Mexico. This taxon was collected in the La Peña Formation of the Francisco Zarco section, at stratigraphic levels $109,110,112,113,117,121,127 \mathrm{c}, 129,132$, and $136 \mathrm{~b}$ (Figure 5). These levels span from the upper part of the middle Aptian Burckhardtites nazasensis/Rhytidoplites robertsi into the lower part of the upper Aptian Cheloniceras inconstans Zone (Figure 11, in pocket) within microfacies zone I (Figure 7) of the La Peña Formation. Petrographic and geochemical characteristics of these levels have been previously discussed on the remarks of preceding taxa.

\section{Occurrence:}

Parahoplites mexicanus has only been found in the La Peña Formation in northeastern Mexico, where it has been reported at Rincon de Los Potreritos, Sierra de Los Muertos, in the State of Coahuila (Humphrey, 1949), and at the Presa Francisco Zarco section, Sierra del Rosario, in Durango State (this work). Its limited occurrence in Mexico suggests that it may be endemic to that area. 


\section{CHAPTER 9. DISCUSSION}

\section{BIOSTRATIGRAPIIIC IMPLICATIONS}

The data presented in the preceding chapters constitute the fundamental framework for the interpretation of the Barremian/Aptian sedimentary series of northeastern Mexico (Figure

2). Barremian/Aptian stages in the study area are represented by the widely accepted lithostratigraphic units known as the Cupido Formation, its lateral equivalent the Lower Tamaulipas Formation, and the younger La Peña Formation, respectively (Figures 5 and 6). Ammonites assemblages of the La Peña Formation have also been the useful conventional medium used in stratigraphic correlation in the region as advocated in the works of Burckhardt (1925), Humphrey (1949), Cantu (1963), Cantu (1976), and Contreras-Montero (1977). These previous studies using ammonites of the La Peña Formation in northeastem Mexico, only focused on biostratigraphy or taxonomy, and very little attention was given to the detailed sedimentological aspects to address the issue of prevailing paleoenvironmental conditions under which the ammonite-rich rock units were formed. Furthermore, although it was recognized that the ammonite record was intermittent, so far there have been no attempts to assess the possible factors that controlled such a record in the La Peña Formation (Figure 11, in pocket). The lack of integration of biostratigraphic and sedimentological data makes the delimitation of biostratigraphic units a difficult task, and as a consequence, diminished the biochronological value of the Aptian ammonite biozones of northeastern Mexico. This problem was equally heightened by the absence of broad regional correlation between the Mexican ammonite biozones, and their relationship to taxonomic provinciality at that time. Such factors must have certainly played a key role in the specific character of the northeastern Mexican assemblages as progressive westward opening of the Tethys sea resulted in the development of open marine 
connections over a broad area, allowing the dispersal of the Tethyan ammonite biota into the proto-Gulf of Mexico by Early Cretaceous time (Frakes, 1979). In fact, Johnson (1974), argued that the migrant fauna were infuenced by the newly developed environments because of their specific ecological constraints, as previous studies based on ammonite distribution versus facies relationships (Scott 1940b; Wiedmann, 1973) had established a bathymetric distribution of the ammonoid populations of that time. Their studies concluded that Lower Cretaceous ammonoids lived only in the environments represented by the outer and inner shelves, and were excluded from the deeper basinal environments. Their results thus explained why ammonite larvae were unable to travel long distances ( $\$$ cott, 1940b), and the deep oceans formed actual natural barriers that prevented further crossing of the Tethys. The ammonite fauna does show indeed that main centers of endemism within the Tethyan province appear to be developed from the Hauterivian onward when the Lower Cretaceous seas became widely separated (Pozaryska and Brochwicz-Lewinski, 1975; Smith et al, 1981) and vast sedimentary basins developed in northeastern Mexico.

As will be discussed below, the present study shows that bathymetry alone, as can be deduced from the type of facies, was not the only factor that controlled the presence and absence of the ammonite populations recorded in the sequences at Presa Francisco Zarco and La Boca Canyon.

The ammonite biostratigraphic zonation presented in Figure 11 (in pocket) summarizes the temporal distribution of index species within the La Peña Formation from the Francisco Zarco section, where representative taxa occur until the Aptian-Albian boundary. Because of the endemic nature of many of the index taxa used in its construction this new ammonite zonal scheme proposed herein is intended to serve as a correlation framework mostly for the northeastern Mexican region. Although ammonites were present at the La Boca Canyon 
section, their scattered stratigraphic distribution prevented the construction of a biozonal scheme representative of this area. However, identification at this site of index species such as Dufrenoyia justinae, Pseudohaploceras reesidei, Acanthohoplites aschiltaensis, Colombiceras spathi, Penaceras nursiradiatus, Rhytidoplites robentsi, and Parahoplites mexicanus, which are characteristic of the biozones defined at Francisco Zarco section, suggests that the La Peña at both sites were deposited contemporaneously.

Thus, typical assemblages of the four ammonite biozones proposed for northeastem Mexico in this study (Figure 11, in pocket), further confirm the assessment that the age of La Peña Formation at both localities spans the late-early to the late Aptian. Furthermore, an extension of the La Peña Formation into the early Albian can be substantiated even in the absence of ammonites in the uppermost part of the section at Francisco Zarco. The age of the uppermost part of the sequence studied is clearly defined on the basis of planktonic foraminifera (Ticinella, Plate 35, Fig. 5) and tintinids (Colomiellid, Plate 35, Figs. 6-7). Thus, the results of this study corroborate former inferences (Cantu, 1963; Trejo, 1975) that the La Peña Formation in northeastern Mexico extends into the early Albian. Hence, except for the disappearance of the ammonites, the La Peña lithofacies developed during the Aptian grade uneventful into the Albian. Likewise, the ammonite succession presented in Figure 11 (in pocket) and the stratigraphic data discussed in the biostratigraphic section support the chronostratigraphic assignment of the infrajacent Cupido Formation (at Presa Francisco Zarco), and its lateral equivalent, the Lower Tamaulipas Formation (at La Boca Canyon), to the late Barremian-early most Aptian.

\section{PALEOPHYSIOGRAPIIC AND PALEOECOLOGIC IMPLICATIONS}

Data obtained from the microfacies (Plates 1-43) allow further understanding of the matrix and associated microscopic components of the bulk sample, which reveal the paleoenvironmental conditions that prevailed at these locations between the latest Barremian 
to the early Albian time. The microfacies, together with the temporal distribution of the associated groups of microfauna (Figure 8), and the carbon/carbonate values (Figures 9 a$c, 10 \mathrm{a}-\mathrm{c}$ ) have provided valuable insight into the prevailing paleoenvironmental conditions, which are not readily perceived from a macroscopic study of the beds (Figures 5 and 6 ). In fact, at the field scale, the predominately black $(\mathrm{N} 1)$ to grayish black $(\mathrm{N} 2)$, and dark gray (N1) color of the beds is misleading, as they would imply a presumptive prevailing anoxic environment throughout that time. Instead, the microfacies and the faunal components reveal environmental conditions where shallow-water, lowmenergy conditions dominated during accumulation of the limestonc facies of the Cupido Formation, whereas more openmarine conditions with increase terrigenous influx existed during deposition of the La Peña Formation.

These conditions are deduced from detail analyses of the combined data as follows. As can be seen in Plates 1 through 23 from the Francisco Zarco sequence, the fundamental components of the microfauna in the Cupido microfacies consist of well diversified assemblages of miliolid foraminifera, occasional bryozoans (Plate 4, Fig. 1), indicative of a productive benthos in normal marine conditions.

Furthermore, wcll developed oolites at level 45b (Plate 5, Figs. 1-4), level 45c (Plate 6, Figs. 1-4) clearly indicate environmental conditions close to the present analog found in the Bahamas Bank, broad, shallow, warm waters with low-energy waves (Bathurst, 1971). Unlike the modern analog, however, pore water conditions were such that dysoxic conditions favored the preservation of organic carbon (Figure 9).

Taken the present forms as analogs to understand these microfacies, miliolids are known to live attached on vegetation as well as directly on the bottom (Bock, 1969; Wright and Hay, 1969) and they are ubiquitous in back reef lagoons and protected bays. 
As seen in Plate 3, Fig. 4; Plate 4, Figs. 2-4; and Plate 13, figs. 3-4, abundance of fecal pellets indicate that the sediment was thoroughly reworked by bottom feeders probably holothuroids (Baars, 1963).

At Presa Francisco Zarco section, biocalcarenites with oolites and algal fragments of microfacies subunit PFZ-C (Figure 7; Plates 5-6), biocalcirudites with rudists of microfacies subunit PFZ-D (Figure 7; Plates 7.11), and rich benthic foraminiferal asscmblages of microfacies subunit PFZ-G (Figure 7; Plates 14-22) of the Cupido Formation, are in agreement with the traditional assignment of this formation from northeastem Mexico to a shallow-marine platform environment. Additional supportive evidence is provided by the concomitant presence of dolomite within microfacies subunit PFZ-F (Figure 7; Plate 13, Figs. 1-2) of the Cupido Formation. However, despite the shallow nature of the Cupido platform at the Francisco Zarco site, as indicated by the presence of oolites (Plates 5-6), the facies succession shows no evidence for peritidal depth that could have led to evaporative conditions conducive to the formation of primary dolomitic facies. The dolomite here is considered as secondary or diagenetic (Bathurst, 1971; Friedman et al., 1992) with largely idiotopic fabric, as can be seen in Plate 13, Figures 1-2.

The facies of the Cupido platform at Francisco Zarco site, were abruptly succeeded at the end of the early Aptian within the Dufrenoyia justinae Taxon-Range-Zone (Figure 11, in pocket), by facies characterized by a sudden increase in the flux of terrigenous components and significant variation in the calcium carbonate and inorganic carbon contents (Figures 5 and $9 \mathrm{~b}$-c) typical of the La Peña Formation. The marls and shaly limestones of the La Peña Formation at this locality include intermittent ammonites (Figure 11, in pocket), radiolaria, benthonic foraminifera, and tintinids, whereas planktonic foraminifera appear continuously throughout (Figure 8). These occurrences imply perennial conditions favorable to the foraminifera, as well as silica flux sufficient enough to sustain radiolarian productivity in 
the area. Because the radiolaria require normal salinity to thrive, it is unlike that the source of silica was by increased river input per se, therefore the logical inference to their appearance is sustained upwelling, which may have been associated with local upwelling, as radiolaria are not known to occur elsewhere.

At the La Boca Canyon section, on the other hand, the vertical succession of facies of the exposed upper part of the Lower Tamaulipas Formation can be considered as the lateral equivalent of the Cupido as can be defined by its chronostratigraphic position discussed in the section on the biozones. The succession of strata is characterized by a monotonous series of biocalcilutites in which sparse planktonic foraminifera, echinoid, and ostracod fragments are the most abundant components (Plates 37-39). The depth of water indicated by this lithic unit is hard to infer, although the environment was decidedly deeper than that of the Presa Francisco Zarco area, because of the absence of the shallow-water miliolids indicative of lagoonal conditions.

It is generally argued in the literature that the onset of the La Peña event can be correlated with a deepening of the epicontinental sea over the Cupido platform, as discussed previously. It is most remarkable, however, that the results of the present work indicate that the fundamental factors are not strictly those of a deepening event alone, because the deeper site of deposition of the Lower Tamaulipas shows the event as well. Despite the initial differences in depth between the two sites, the transition from the Lower Tamaulipas (Cupido Formation lateral equivalent) to La Peña at La Boca Canyon can also be characterized by an increase in the terrigenous components, and marked fluctuation in the calcium carbonate and inorganic carbon contents (Figure $10 \mathrm{a}-\mathrm{c}$ ), which are the true regional hallmarks of that event. The input of terrigenous materials during the time of deposition of La Peña Formation was constant throughout, although punctuated by episodic higher fluxes, as recorded in the intermittent oscillations of total inorganic carbon 
or carbonate carbon (TIC) throughout the La Peña at both localities (Figures $9 \mathrm{~b}+\mathrm{c}$ and 10 a c).

The formational contact at both localities is also characterized by the appearance of ammonite species, from which Dufrenoyia justinae is the most distinguishable biostratigraphic marker because it marks the first appearance of recorded ammonites in the Francisco Zarco section at stratigraphic level PFZ-61, which is only $7 \mathrm{~cm}$ above the Cupido/La Peña lithic formational contact (Figures 5 and 7). The appearance of the ammonites at this formational contact has traditionally been associated with the onset of a transgressive event that drowned the Cupido carbonate platform in northeastern Mexico throughout the Aptian (Imlay, 1944; Wilson \& Pialli, 1977; Smith, 1981). The presumed drowning event is argued to have allowed the ammonite faunas to migrate into the area of study as the water level rose. As discussed above, the ammonites presumably migrated into the area in response to the newly developed open-marine environment and its associated type of ecologic conditions, which might have favored sustained ammonite populations throughout the sedimentary basins during the Cretaceous (Scott, 1940b; Marchand, 1982). However at the La Boca Canyon section, despite pre-existing deeper-water conditions the first record of ammonites is also marked by the first appearance of Dufrenoyia justinae at stratigraphic level LB A-17, or 1.8 meters above the formational contact between the Lower Tamaulipas and the La Peña (Figures 6 and 7). Based on the type of facies that characterize the La Peña Formation at both sites, it is logical to assume that ammonite occurrences within the environments at both localities were synchronous.

Comparison of the two sections indicate that the sedimentation rate of the La Peña Formation was higher at the depositional site of the La Boca Canyon than that at Francisco Zarco (Table 1). Estimates of these sedimentation rates were based on the thicknesses of each individual biozone at Francisco Zarco and the estimated absolute ages of their boundaries in accordance with the absolute time scale of Gvirtzman et al. (1996) (Figure 
11, in pocket; and Table 1). Sedimentation rate for the La Boca Canyon section was calculated on the basis of the total thickness of the entire formation, due to lack of biostratigraphic subdivisions, and assuming that La Peña spans the same amount of years at both localities.

A

\begin{tabular}{|c|c|c|c|}
\hline $\begin{array}{c}\text { Ammonite Biozone } \\
\text { Francisco Zarco }\end{array}$ & $\begin{array}{c}\text { Time Interval } \\
\text { (million years) }\end{array}$ & $\begin{array}{c}\text { Thickness } \\
\text { (meters) }\end{array}$ & $\begin{array}{c}\text { Sedimentation Rate } \\
\text { (cm/1 000 years) }\end{array}$ \\
\hline $\begin{array}{c}\text { Dufrenoyia justinae } \\
\text { Taxon-Range-Zone }\end{array}$ & 1.5 & 9.4 & 0.626 \\
\hline $\begin{array}{c}\text { B. nazasensis/ } \\
\text { R. robertsi }\end{array}$ & 2.5 & 6.8 & 0.272 \\
\hline $\begin{array}{c}\text { Interval Zone } \\
\text { C. inconstans }\end{array}$ & 1 & 7.6 & 0.760 \\
\hline $\begin{array}{c}\text { Taxon-Range-Zone } \\
\text { H. cf. leanzae }\end{array}$ & 4 & 21.8 & 0.545 \\
\hline \begin{tabular}{l} 
Taxon-Range-Zone \\
\hline
\end{tabular}
\end{tabular}

B

\begin{tabular}{|c|c|c|c|}
\hline $\begin{array}{c}\text { La Peña Formation, } \\
\text { La Boca Canyon }\end{array}$ & $\begin{array}{c}\text { Time Interval } \\
\text { (million years) }\end{array}$ & $\begin{array}{c}\text { Thickness } \\
\text { (meters) }\end{array}$ & $\begin{array}{c}\text { Sedimentation Rate } \\
(\mathrm{cm} / 1000 \text { years) } \\
11.5\end{array}$ \\
\hline
\end{tabular}


Table 1. Sedimentation rate of ammonite biozones within the La Peña Formation at (A) Presa Francisco Zarco and (B) La Boca Canyon sections.

Thus, taking into consideration that the estimated sedimentation rate at the beginning of deposition of the La Peña Formation at La Boca site was $1.24 \mathrm{~cm} / \mathrm{Kyr}$, whereas at Francisco Zarco this rate was $6.26 \mathrm{~mm} / \mathrm{Kyr}$, the 1.8 meters of the lower part of the La Peña at $\mathrm{La}$ Boca without ammonite records would represent about 145, 000 years, whereas the 7 $\mathrm{cm}$ of basal La Peña without ammonites at Francisco Zarco section would represent about 11, 000 years. These numbers imply that the first occurrence of Dufrenoyia justinae is approximately time equivalent at both sites, although the onset of the facies changes or formational contacts in the Barremian-Aptian sequences of this study would imply diachrony.

As mentioned above, this formational contact at both sites is believed to be coeval with the onset of a transgressive event, and therefore it is commonly debated that the appearance of the ammonites at La Boca Canyon must have also been a direct effect of the rising sea level in the area. However, as discussed previously in the stratigraphic framework of this work, the Lower Tamaulipas and the La Peña Formations at this locality are both lithologically similar, being different only by the increase of terrigenous fluxes in the La Peña, suggesting that the water depth being the controlling factor favorable for the presence of the ammonites would have been situable since the Lower Tamaulipas time. Based on this observations, the first appearances of Dufrenoyia justinae as well as the rest of the ammonite species in the areas of study, may have been related to factors other than an increase in the bathymetry, as will be discussed below.

Another important aspect of the ammonite occurrences is their intermittent record at both sites. What was the principal determinant factor controlling the presence or absence of the ammonites in the succession of strata at both sites?

Concerning the intermittence of the ammonites one could argue that the pattern was due to sporadic preferential shell removal, or destruction of the shell. The microfacies does 
indicate record of small molluskan fragments that could be related to fragments of ammonites (Plate 28, Fig. 3; Plate 29, Fig. 7; Plate 30, Fig. 4; Plate 31, Fig. 10) even though there were no recorded macrofossils at these levels. The possibility remains that the ammonites were present in insufficient numbers to have random significant record. Perhaps species significantly more common in the population were only more resistant, and the least resistant ones destroyed? This aspect remains unknown because no previous study exist on ammonite shell dissolution in this area.

Although the ammonites seem to occur in strata with more terrigenous components, the overall carbonate production (Figures $9 \mathrm{~b}-\mathrm{c}$ and $10 \mathrm{a}-\mathrm{c}$ ) does not demonstrate a close relationship with the presence of the ammonites, therefore dissolution of carbonate can be ruled out as a determinant factor.

This stratigraphic pattern may be the result of environmental conditions that controlled the facies, as can be attested to by the abundance of ammonites on marly limestones and their gradual disappearance as the facies becomes pure limestone. This observation could explain the greater abundance of ammonites at Presa Francisco Zarco in relation to the La Boca Canyon site, where the overall facies are characterized by less terrigenous materials and more pure limestones than those of the Francisco Zarco (Figures $9 \mathrm{~b}-\mathrm{c}$ and $10 \mathrm{a}-\mathrm{c}$ ), which was a more proximal site. Thus, the data herein indicate that the ammonites were attracted to areas with enhanced availability of resources, which may have resulted from increased productivity due to the progressive inflow of nutrients carried by the source of the terrigenous materials. The differential abundance of ammonites at both sites, further suggests that the La Boca Canyon may represent a more distant area to that source than the Francisco Zarco site. These characteristic facies of the La Peña Formation accumulated at both sites throughout the remaining time of the Aptian. 


\section{PALEOCEANOGRAPHIC IMPLICATIONS}

On the other hand, based on the pattern of occurrence of the microfauna, particularly benthonic foraminifera, planktonic foraminifera, and radiolaria (Figure 8), as well as on the pattern of preservation of $\mathrm{C}_{\text {org }}$-rich sediments (Figures $9 \mathrm{a}-\mathrm{c}$ and $10 \mathrm{a}+\mathrm{c}$ ), the La Peña facies are interpreted to represent an environment in which the overall conditions controlling productivity in the water column changed. Superimposed on these broader changes, there appear intermittent variations which may have allowed periodic occurrences of ammonites as previously discussed. Moreover, as explained in the presentation of the data of the carbon/carbonate analyses of this work, the Cupido/La Peña formational contact at Francisco Zarco is not only characterized by an increase of the terrigenous components and a dramatic drop of the benthic fauna, but also by an increase in the total organic carbon contents from less than $1 \%$ to values oscillating between 3 and $5 \%$, as can be seen in Figure 9. Organic carbon-rich sediments are normally the byproducts associated with periods of unique paleoceanographic conditions in which oxygenation of oceanic waters was apparently less effective than usual (Schlanger and Jenkyns, 1976; Ryan and Cita, 1977; Arthur and Schlanger, 1979; Jenkyns, 1980). However, Pedersen and Calvert (1990) argued that enhanced productivity has played an important role in the formation of such $\mathrm{C}_{\mathrm{org}}$-rich sediments and sedimentary rocks through geologic time, and questioned the role of anoxia as the unique control in the preservation of $\mathrm{C}_{\text {org }}$ in general. In the case of the lower part of the La Peña Formation at Francisco Zarco, the coincident increase on the values of total organic carbon in the upper part of microfacies subunit H (Figures 7 and 9b), just before the appearance of the planktonic fauna characteristic of microfacies subunit I, and the dramatic decrease of the benthonic foraminifera production (Figure 8), suggests that this was the beginning of a period of oxygen depletion coupled with a rise of relative sea level. The fact that these sedimentary conditions prevailed until stratigraphic level PFL100 , as previously explained in the section discussing the carbon/carbonate content, the 
aforementioned paleoceanographic conditions seem to have been present throughout the time represented by the proposed Dufrenoyia justinae Taxon-Range-Zone for the lower Aptian of northeastern Mexico (Figure 11, in pocket). This event may be correlative with a brief interval of peak oxygen deficiency in the early Aptian, as suggested by the work of Bralower et al. (1994), who recognized extensive preservation of $\mathrm{C}_{\mathrm{org}}$-rich sediments attributable to processes of dysoxia/anoxia in the world oceans at that time. The timing of this event is correlative to the late early Aptian Selli Event (= Oceanic Anoxic Event la) (Arthur et al, 1990; Bralower et al, 1994). Despite the absence of benthonic foraminifera, the concomitant presence of echinoid fragments on rocks representative of this interval from the lower part of the La Peña Formation, suggest that the bottom of the ocean at this area may have not been completely anoxic at that time.

The fact that at La Boca Canyon, the total organic carbon (TOC) values were already oscillating between $1.45 \%$ (stratigraphic level LB A-1) and $4.32 \%$ (stratigraphic level LB A-8), since the Lower Tamaulipas time (Figure 10 a, Appendix 3), further suggests that this depletion of oxygen of the bottom waters was happening prior to the beginning of deposition of the La Peña Formation, and probably the sedimentary signal of this event was not recorded in rocks of the Cupido Formation at the Francisco Zarco site, due to the shallow nature of that area at that time. In fact, the total organic carbon values (TOC) at La Boca Canyon are maintained relatively higher throughout the complete sedimentary sequence, as previously explained in the carbon/carbonate analysis (Appendix 3).

As stated by Bralower et al. (1994), depletion in dissolved oxygen levels in the lower Aptian oceans may have been related to tectono-volcanic events such as increased production of mid-oceanic crust. In fact, Ar-Ar age data of drilled and on-land samples from the Ontong Java Plateau suggest that the early Aptian was a time of increased superplume activity that may have caused an increase in the overall temperature of the oceans, and therefore, enhanced the world-wide sea level rise at that time (Tatsumi et al., 
1998). Subsequent to this apparently dysoxic event, there was an episode of normal paleoceanographic conditions. This is suggested by the reappearance of the benthonic foraminifera and a drop of the total organic carbon values to less than $1 \%$ from stratigraphic levels PFZ-101 to PFZ-136b (Figure 9-c, Appendix 2). This interval is coincident with the span of time represented by the Burckhardtites nazasensis/Rhytidoplites robertsi Interval-Zone and most of the Cheloniceras inconstans Taxon-Range-Zone of the ammonite biozonal scheme proposed for this work (Figure 11, in pocket), therefore spans from the middle Aptian to the early-late Aptian. Subsequent paleoceanographic changes seem to be recorded by the interval between stratigraphic levels PFZ-136c and $162 \mathrm{~b}$. This part of the section spans from the upper part of Cheloniceras inconstans Taxon-RangeZone into the lower half of Hypacanthoplites cf. leanzae Taxon-Range-Zone of the same zonal scheme, therefore it is correlative with the middle-late Aptian. The record of the highest total organic values within this part of the section, sometimes as high as $18.39 \%$ (stratigraphic level PFZ-137; Figure 9.c; Appendix 2), would suggest possible dysoxic/anoxic bottom conditions, however, the constant appearance of benthonic fauna within this interval, including echinoid fragments (Plate 29, Fig. 6; Plate 31, Fig. 10) and foraminifera (Figure 8), favor the idea of possible changes in term of enhanced productivity instead. This period of apparent enhanced productivity of the water column in this area, continued through the remaining of the Hypacanthoplites cf. leanzae Taxon-Range-Zone of the late Aptian of the same zonal scheme (Figure 11, in pocket). This inference is reinforced by the continuous high values of organic carbon recorded in the remaining of the stratigraphic sequence, from stratigraphic level PFZ-162c to stratigraphic level PFZ-203 (Figure $9_{\mathcal{c}}$, Appendix 2). Moreover, the sudden appearance and abundance of radiolaria within this interval, which corresponds to microfacies subunits $J$ and $\mathrm{K}$ (Figure 7), further suggest that the basin in this area of Mexico was also characterized by the development of upwelling systems during the latest Aptian (Maurrasse 1976, 1978, 1993; Maurrasse and 
Keens-Dumas, 1988). The fact that these sedimentary signals prevailed up to the uppermost part of the stratigraphic section, even above the upper boundary of the Hypacanthoplites cf. leanzae Taxon-Range-Zone (Figure 11, in pocket), is an indication that these upwelling conditions may have been one of the main paleoceanographic processes that influenced the sedimentation of the area through the Aptian/Albian boundary. 


\section{CHAPTER 10. CONCLUSIONS}

The principal objective of this work was to improve the Aptian ammonite biochronological scheme based on the stratigraphic records of northeastern Mexico. The results of the biostratigraphic study summarized in Figure 11 (in pocket) are derived from the study of a continuous Barremian/Aptian Albian sequence at Presa Francisco Zarco in Durango State (Figure 2). Four ammonite zones are described in the La Peña Formation :

1.- The Dufrenoyia justitua Taxon-Range-Zone essentially characterized by the full range of occurrence of Dufrenoyia justinae. The present assignment of this zone to the uppermost ammonite zone of the lower Aptian is based on correlation with the Dufrenoyia furcata Zone of the Mediterranean region.

\section{2.* The Burckhardtites nazasensis/Rhytidoplites robertsi Interval-Zone}

defined by the combined ranges of the characterizing nominate taxa. The base of the zone is delimited by the first appearance of Burckhardtites nazasensis, whereas the upper part of the zone is distinguished by the full range of Rhytidoplites robertsi. This zone is also characterized by a rich assemblage of ammonite species, showing the highest diversity in the Presa Francisco Zarco section. The Burckhardites nazasensis/Rhytidoplites robentsi Zone is correlative with the informal zone named "unidad con Rhytidoplites" by Contreras" Montero (1977), which was recognized in the La Peña Formation of northeastem Mexico.

\section{3.- The Cheloniceras inconstans Taxon-Range-Zone which is defined by the first} appearance and full range of the nominate taxon, concurrently with Cheloniceras fossae. This zone is further characterized by the presence of Pseudohaploceras aguilerae, $P$. jacobi, and P. reesidei .

4.- The Hypacanthoplites cf. leanzae Taxon-Range-Zone distinguished by the first appearance of the nominate species. The basal part of this biozone is also characterized by having the last stratigraphic occurrence of Pseudohaploceras reesidei, and this zone is 
rather poor in ammonites, as it contains mostly one species throughout. The top of the zone is designated to coincide with the last appearance of Hypacanthoplites cf. leanzae. This biozone is correlative with the Hypacanthoplites jacobi zone characteristic of the uppermost part of the upper Aptian of England (Casey, 1961) and the Mediterranean region (Hoedemaeker et al., 1993). It is also equivalent to the informal unit "unidad con Hypacanthoplites jacobi" defined by Contreras-Montero (1977) for the La Peña Formation of northeastern Mexico.

These zones can be correlated approximately with the uppermost part of the Bedoulian, the Gargasian and Clansayesian substages (Figure 4) of the traditional Aptian series in southern France.

In addition to the new ammonite zonal scheme presented in this work, the results further reveal that the occurrence of the ammonites show a consistent record of intermittence, which caused difficulties in establishing the actual temporal relationship of the taxa to zonal boundaries. Because of this recurrent pattern, a basic understanding of the paleoenvironmental conditions recorded in the sediments has been developed based on microfacies, and carbon/carbonate analyses.

The detailed analysis of the succession of microfacies types present in the stratigraphic sequences studied, allows to distinguish seven subunits or microfacies zones within the Cupido Formation (PFZ-A through G), and four subunits or microfacies zones (PFZ-H through PFZ-K) in the La Peña Formation (Figure 7) in the Francisco Zarco section.

The La Pcña Formation at La Boca Canyon shows rather monotonous microfacies throughout, and they are similar to those of the infrajacent Lower Tamaulipas Formation. The main difference is marked by the presence of belemnite rostra in the upper part of the La Peña Formation which are not present in the microfacies of the Lower Tamaulipas Formation. Belemnite rostra have not been found in the microfacies of the La Peña 
Formation at Francisco Zarco. However, the hallmark of the La Peña Formation remain similar at both sites, and consists of an increase in the relative amount of terrigenous components and organic carbon (Figures $9 b-c$ and $10 a-c$ ).

The episode represented by the beginning of deposition of the La Peña Formation is marked by changes from well diversified benthonic foraminifera assemblages in the Cupido facies to a decrease in the abundance of benthonic organisms in the La Peña Formation, as well as an increase in total organic carbon. Since the presence of planktonic organisms remained constant, these changes are interpreted to register an apparent oxygen depletion in the lower part of the water column. The dysoxic/anoxic conditions appear to be correlative with magmatic events during the Aptian, which may have caused an increase in the overall temperature of the oceans (Tatsumi et al., 1998), and led to an expansion of the oxygen minimum zone over the shelf waters at that time worldwide. The sudden drop of the benthonic fauna is here interpreted to have been caused mostly by the effects of changes on bottom environmental conditions, which enhanced the relative deepening effect of the water column in northeastem Mexico. This interpretation is supported by the record of radiolaria (Figure 8) indicating enhanced productivity associated with an upwelling system established in the region in the late Aptian-early Albian.

The biozonation presented in this work provides further stratigraphic resolution with the use of ammonites, and the conclusions drawn in this work will hopefully stimulate further investigations in order to fully understand the relationship between ammonite paleoecology and the associated sedimentary record.

Future investigation on the intermittence of the ammonites over the Tethyan region will certainly be useful to correlate the pattern of this unusual biostratigraphic phenomenon to environmental and sedimentological factors. 


\section{LIST OF REFERENCES}

Anthula, D. J., 1899.1900, Über die Kreidefossilien des kaukasus mit einem allegemeinen Ueberblick über die Entwicklung der Sedimentärbildungen des Kaukasus: Beitraege zur Palaeontologie und Geologie Oesterreich-Ungarns und des Orients, Bd 12, p. 54-159, pl. $1-14$.

Arkell, W. J., Kummel, B., and Wright, C. W., 1957, Mesozoic Ammonoidea, In: Treatise on Invertebrate Paleontology, Part L, Mollusca, Geological Society of America and University of Kansas Press, p. 11-490, 558 figs.

Arthur, M. A., Brumsack, H. J., Jenkyns, H. C., and Schlanger, S. O., 1990, Stratigraphy, geochemistry, and paleoceanography of organic carbon-rich Cretaceous sequences, in Ginsburg, R. N., and Beaudoin, B., eds., Cretaceous Resources, Events, and Rhytms: Kluwer Academic Publications, p. 75-119.

Arthur, M. A., and Schlanger, S. O., 1979, Cretaceous "oceanic anoxic events" as causal factors in development of reef-reservoired giant oil fields: American Association of Petroleum Geologists Bulletin, v. 63, p. 870-885.

Astier, J. E., 1851, Catalogue descriptif des Ancyloceras appartenant á l'étage Néocomien d'Escragnolles et des Basses-Alpes: Annales de la Societe Nationale d'Agriculture, d'Historie Naturelle et des Arts Utiles de Lyon, v. 3, no. 2, p. 435-456, pl. 15-23.

Baars, D. L., 1963, Petrology of carbonate rocks, In Shelf carbonates of the Paradox Basin, Symposium Fourth Field Conference Four Corners Geological Society, p. 101129.

Barragan, R., 1999, Sedimentary facies and organic carbon variations in Barremian-Aptian sequences of northeastern Mexico: Revista Española de Micropaleontología, v. 31, no. 3, p. 305-314.

Bathurst, R. G. C., 1971, Carbonate Sediments and their diagenesis, In Developments in Sedimentology, Textbook edition, Elsevier, v. 12, 658 pp. 
Bishop, B. A, 1970, Stratigraphy of Sierra de Picachos and vicinity, Nuevo Leon, Mexico: American Association of Petroleum Geologists Bulletin, v. 54, no. 7, p. 1245-1270.

Bock, W. D., 1969, A handbook of the benthonic foraminifera of Florida Bay and adjacent waters: Miami Geological Society Memoir 1, A Symposium of recent south Florida foraminifera, p. 1-72.

Böse, E., 1923, Vestiges of an ancient continent in Northeast Mexico: American Journal of science 206, 127-136, 196-214, 310-337.

Böse, E., and Cavins, O. A., 1927, The Cretaceous and Tertiary of Southern Texas and Northern Mexico: University of Texas Bulletin, no. 2748, p. 1-142.

Bralower, T. J., Arthur, M. A., Leckie, R. M., Sliter, W. V., Allard, D. J., and Schlanger, S. O., 1994, Timing and Paleoceanography of Oceanic Dysoxia/Anoxia in the late Barremian to early Aptian (early Cretaceous): SEPM (Society of Sedimentary Geology), Palaios, v. 9, p. 335-369.

Breistroffer, M., 1947, Sur les zones d'Ammonites dans l'Albien de France et d'Angleterre: Travaux du Laboratoire de Geologie de la Faculte des Sciences de I'Universite de Grenoble, no. 26, p. 17-104.

Burckhardt, C., 1906, La Faune Jurassique de Mazapil avec un appendice sur les fossiles du Crétacique Infériéur: Boletín del Instituto de Geología de México, no. 23, 219 pp., 43 láms.

Burckhardt, C., 1912, Faunes Jurassiques et Crétaciques de San Pedro del Gallo, Durango: Boletín del Instituto de Geología de México, no. 29, 264 pp., 46 láms.

Burckhardt, C., 1925, Faunas del Aptiano de Nazas (Durango): Boletín del Instituto de Geología de México, v. 45, 71 pp., 10 láms.

Burckhardt, C., 1930, Etude synthétique sur le Mesozoique Mexicain: Mémoire de la Société Paléontologique de Suisse, 49-50, 280 pp, 65 fig. 
Bürgl, H., 1956, La variabilidad de la Amonita Dufrenoya texana Burckhardt: Boletín Geológico, Bogota, v. 4, no. 2-3, p. 1-22, 3 pls.

Cantu Ch., A., 1963, Étude Biostratigraphique des Ammonites du Centre et de l'est du Mexique (Jurassique supérieur et Crétacé): Mémoire de la Société Géologique de France no. 99 , N. S. Tome XLII, Fasc. 4, 102 p., VIII pl.

Cantu Ch., C. M, 1976, Estratigrafía de la Formación La Peña (Aptiano Superior) en el Area de Monterrey, N. L.: Revista del Instituto Mexicano del Petróleo, v. VIII, no. 4, p. 7 . 16, 1 lám.

Casey, R., 1961, The Stratigraphical Paleontology of the Lower Greensand: Paleontology, no. 3 , p. $487-621$.

Conklin, J., and Moore, C. H, 1977, Paleoenvironmental analysis of the Lower Cretaceous Cupido Formation, northeast Mexico, in Bebout, D. G., and Loucks, R. G., eds., Cretaceous carbonates of Texas and Mexico-applications to subsurface exploration: University of Texas, Austin, Bureau of Economic Geology, Report of Investigation no. 89. p. 320-323.

Contreras-Montero, B., 1977, Bioestratigrafía de las formaciones Taraises y La Peña (Cretácico Inferior), de La Goleta, Coahuila y Minillas, Nuevo León: Revista del Instituto Mexicano del Petróleo, v. IX, no. 1, p. 8-17.

Cragin, F. W., 1893, A Contribution to the Invertebrate Palaeontology of the Texas Cretaceous: Geological Survey of Texas, Annual Report no. 4, Pt. 2, p. 141-295, pls. 24 46.

De Cserna, Z., 1956, Tectónica de la Sierra Madre Oriental entre Torreón y Monterrey: XX Congreso Geológico Internacional (México), Monografía, 87 pp.

De Csema, Z., Graf, J. L., and Ortega, F. G., 1977, Alóctono del Paleozoico inferior en la región de Ciudad Victoria, Tamaulipas: Revista del Instituto de Geología, Universidad Nacional Autónoma de México, no. I, p. 33-43. 
Diaz, T., 1953, Itinerario de la excursión al Cañón de la Peregrina, Tamaulipas: Primera Convención de la Asociación de Geólogos Petroleros, Libreto Guía, 6 pp.

Egoian, V. L., 1974, O novom semeistve razvemutykh ammonitov iz apta zapadnogo Kavkaza: Doklady Akademii Nauk SSSR, v. 217, no. 4, p. 939-942, fig. 1.

Etayo Serna, F., 1979, Zonation of the Cretaceous of central Colombia by Ammonites: Publicaciones Geológicas Especiales del Ingeominas, Bogotá, no. 2, p. 1-186, 15 pl.

Fabre-Taxy, S., Moullade, M., and Thomel, G., 1965, A-Les stratotypes de l'Aptien, in Colloque sur le Crétacé Inférieur, Lyon: Memoir du Bureau de Recherches Geologiques et Miniéres, no. 34, p. 173-226.

Favre, F, 1908, Die Ammoniten der unteren Kreide Patagoniens: Neues Jahrbuch fuer Mineralogie, Geologie und Palaeontologie, Beilage-Band 25, p. 601-604, fig. 1-7, pl. 3237.

Flügel, E., 1982, Microfacies analysis of limestones. Springer-Verlag, Berlin, Heidelberg, $633 \mathrm{pp}$.

Folk, R. L., 1959, Practical petrographic classification of limestones: American Association of Petroleum Geologists Bulletin, v. 43, p. 1-38.

Folk, R. L., 1962, Spectral subdivision of limestone types, in Ham, W. E. ed, Classification of carbonate rocks: American Association of Petroleum Geologists, Memoir 1, p. $62-84$.

Forgotson, J. M., Jr., 1957, Stratigraphy of Comanchean Cretaceous Trinity Group (Gulf Coastal Plain): American Association of Petroleum Geologists Bulletin, v. 41, no. 10, p. 2328-2363.

Frakes, L. A., 1979, Climates throughout geologic time, Elsevier Scientific Publishing Company, Amsterdam, 310 pp. 
Friedman, G. M., Sanders, J. E., and KopaskamMerkel, 1992, Principles of sedimentary deposits, Macmillan, New York, 717 pp.

Fritel, P. 1906, Sur les variations morphologiques d'Acanthoceras milletianum, d'Orbigny sp.: Le Naturaliste, Paris, 28 th year, series 2, no. 427, p. 245-257.

Gill, T., 1871, Arrangement of the Families of Mollusks: Smithsonian Miscellaneous Collections 227 , xvi +49 pp.

Goldhammer, R. K., Lehmann, P. J., Todd, R. G., Wilson, J. L., Ward, W. C., and Johnson, C. R., 1991, Sequence Stratigraphy and Ciclostratigraphy of the Mesozoic of the Sierra Madre Oriental, Northeast Mexico, A Field Guide Book: SEPM (Society of Sedimentary Geology), Gulf Coast Section, 84 pp.

González-Garcia, R., 1976, Bosquejo geológico de la Zona Noreste: Asociación Mexicana de Geólogos Petroleros, Boletín, v. 28, no. 1 and no. 2, p. 2-49.

Gvirtzman, G., Weissbrod, T., Baer, G., and Brenner, G. J., 1996, The age of the Aptian Stage and its magnetic events: new Ar-Ar ages and paleomagnetic data from Negev, Israel: Cretaceous Research, v. 17, p. 293-310.

Hedberg, H. D., 1976, International stratigraphic guide. A guide to stratigraphic classification, terminology, and procedure. John Wiley and Sons, New York, 200 pp.

Hill, R. T., 1887, The topography and geology of the Cross Timbers and surrounding regions in northern Texas: American Journal of Science, series 3, v. 33, p. 291-303.

Hill, R. T., 1893, Paleontology of the Cretaceous formations of Texas: The invertebrate paleontology of the Trinity Division: Proceedings of the Biological Society of Washington, v. 8, p. $9-40,8$ pls.

Hill, R. T., 1901, Geography and geology of the Black and Grand prairies, Texas: United States Geological Survey, Annual Report no. 21, Pt. 7, 666 pp. 
Hoedemaeker, P. J., Company, M., Aguirre-Urreta, M. B., Avram, E., Bogdanova, T. N., Bujtor, L., Bulot, L., Cecca, F., Delanoy, G., Ettachfini, M., Memmi, L., Owen, H. G., Rawson, P. F., Sandoval, J., Tavera, J. M., Thieuloy, J. P., Tovbina, S. Z., and Vasicek, Z., 1993, Ammonite zonation for the Lower Cretaceous of the Mediterranean Region; Basis for the Stratigraphic Correlations within IGCP-Project 262: Revista Española de Paleontología, v. 8, no. 1, p. 117-120.

Humphrey, W. E., 1949, Geology of the Sierra de Los Muertos Area, Mexico (with descriptions of Aptian Cephalopods from the La Peña Formation): Geological Society of America Bulletin, v. 60 , p. 89-176, 2 figs., 18 pls.

Humphrey, W. E., 1956a, Tectonic framework of northeast Mexico: Gulf Coast Association of Geological Societes Transactions, v. 6, p. 25-35.

Humphrey, W. E., 1956b, Bosquejo geológico de la región que cruzara la excursión C-5, in, Maldonado-Koerdell, eds., Estratigrafía del Mesozoico de Monterrey a Torreón: XX Congreso Geológico Internacional, Excursión C-5.

Hyatt, A., 1889, Genesis of the Arietidae: Smithsonian Contributions to Knowledge, no. 673, Washington, D. C. xi +238 pp., 14 pls.

Hyatt, A., 1894, Phylogeny of an acquired characteristic: Proceedings of the American Philosophical Society, no. 32, p. 348-647, pl. 1-14+2 unnumbered pl.

Hyatt, A., 1900, Cephalopoda, in Zittel, K. A., Textbook of Palaeontology, 1st English ed., translated by C. R. Eastman: Macmillan, London \& New York, p. 502-592.

Imlay, R. W., 1936, Evolution of the Coahuila Peninsula, Mexico: Part IV, Geology of the western part of the Sierra de Parras: Geological Society of America Bulletin, v. 47, p. $1091-1152$.

Imlay, R. W., 1937, Geology of the middle part of the Sierra de Parras, Coahuila, Mexico: Geological Society of America Bulletin, v. 48, p. 587-630. 
Imlay, R. W., 1938, Studies of the Mexican Geosyncline: Geological Society of America Bulletin, v. 49, p. 1651-1694.

Imlay, R. W., 1940, Possible interoceanic connections across Mexico during the Jurassic and Cretaceous Periods: Proceedings on the Pacific Sciences Congress, v. 1, p. 423-427, 1 tb.

Imlay, R. W., 1944, Cretaceous formations of Central America and Mexico: American Association of Petroleum Geologists Bulletin, v. 28, no. 8, p. 1077-1195.

Jenkyns, H. C., 1980, Cretaceous anoxic events: from continents to oceans: Geological Society of London, Journal, v. 137, p. 171-188.

Johnson, J. G., 1974, Extinction of perched faunas: Geology, v.2, no. 10, p. 479-482.

Kazansky, P. A., 1914, Déscription d'une collection des Céphalopodes des terrains Crétacés du Daghestan: Izv. Tomskago Technol. Inst., v. 32, no. 4, 127 pp., 7 pls.

Kemper, E., 1970, Ein Beitrag Zur Gliedering und Abgrenzung des norddeutschen: Aptian Newsletter Stratigraphy, v. 1, n. 1, p. 49-52, 2 tabl.

Kilian, W., 1888a, Description Géologique de la Montagne de Lure (Basses-Alpes), These de Doctorate, Masson, Paris, 458 pp., 8 pls., 59 figs.

Kilian, W., 1888b, Sur quelques fossiles nouveaux ou peu connus du Crétacé inférieur de la Provence: Bulletin de la Societe Geologique de France, ser. 3, t. 16, p. 663-691, pls. $17-21$.

Kilian, W., 1907.1913, Das bathyale Palaeocretacicum im südöstlichen Frankreich. Valendis-stufe; Hauterive-stufe; Barrême-stuf; Apt-stufe, in Frech, F., ed., Lethaea Geognostica: Teil II (Das Mesozoicum), Band 3 (Kreide), Abt. 1, Unterkreide (Palaeocretacicum), Lieferung 2, p. 169-287, Schweizerbart, Stuttgart. 
Kilian, W., and Reboul, P., 1915, Contribution à l'étude des faunes paléocrétacés du Sudest de la France. I La faune de l'Aptien inférieur des environs de Montelimar (Drôme): Memoires pour Servir a l'Explication de la Carte Geologique Detaillee de la France, p. 1* 221,9 pls., 10 figs.

Lasswitz, R. von, 1904, Die Kreide-Ammoniten von Texas (collectio F. Roemer): Geologische und Palaeontologische Abhandlungen, Band X, Heft 4, 46 pp., 8 pls.

LECO Corporation, 1997, CR-412 Carbon Analyzer Instruction Manual.

Lehmann, Ch., Osleger, D. A., and Montañez, I. P., 1998, Controls on Cyclostratigraphy of Lower Cretaceous Carbonates and Evaporites, Cupido and Coahuila Platforms, Northeastem Mexico: Joumal of Sedimentary Research, v. 68, no. 6, p. 1109-1130.

Lehmann, U., 1981, The ammonites, their life and their world, Cambridge University Press, New York, 239 pp.

Lopez-Ramos, E., 1979, Geología de México, segunda edición, v. III, 444 pp.

Lynts, G. W., 1969, Distribution and model studies on foraminifera living in Buttomwood Sound, Florida Bay: Miami Geological Society Memoir 1, A Symposium of recent South Florida foraminifera, p. 73-115.

Marchand, D., 1982, Ammonites et paléoenvironnements; une nouvelle approche: Geobios, Mémoir spécial no. 8, p. 101-109.

Maurrasse, F. J., 1976, Paleoecologic and paleoclimatic implications of radiolarian facies in Caribbean Paleogene deep-sea sediments, in Causse, R., ed., 7th Caribbean Geological Conference, Transactions, p. 185-204.

Maurrasse, F. J., 1978, Cenozoic radiolarian Paleobiogeography: Implications concerning plate tectonics and climatic cycles: Palaeogeography, Palaeoclimatology, Palaeoecology, v. 26, p. $253-289$. 
Maurrasse, F. J., 1993, Taxonomy, biostratigraphy, and paleoecologic significance of calcareous-siliceous facies of the Neogene Montpelier Formation, northeastern Jamaica: Geological Society of America, Memoir 182, p. 255-282.

Maurrasse, F. J., and Keens-Dumas, J. E., 1988, Calcareous-siliceous sediments in southwestern Trinidad and radiolarian lithofacies diachrony in the Caribbean Neogene: 11 th Caribbean Geological Conference, Transactions, p. 7:1-7:10

Miller, A. K., and Harris, R. A., 1945, North American Cymatoceratidae (Mesozoic Nautiloidea): Journal of Paleontology, v. 19, p. 1-13,6 pls.

Moran-Zenteno, D., 1994, Geology of the Mexican Republic: American Association of Petroleum Geologists, Studies in Geology no. 39, $160 \mathrm{pp}$.

Muir, J. M., 1936, Geology of the Tampico region, Mexico: Tulsa, Oklahoma, American Association of Petroleum Geologists, $200 \mathrm{pp}$.

North American Commission on Stratigraphy Nomenclature, 1983, North American stratigraphic code: American Association of Petroleum Geologists Bulletin, v. 67, p. 841 875.

Orbygni, A. D', 1840-1842, Paléontologie Française. Terraines Crétacés. I: Cephalopodes: Masson, Paris, 662 pp., 148 pls.

Parona, C. F., and Bonarelli, G., 1897, Fossili Albiani d'Escragnolles del Nizzardo e della Liguria occidentale: Palaeontographia Italica, v. 2, p. 53-112, pl. 10-14.

Pedersen, T. F., and Calvert, S. E., 1990, Anoxia vs, productivity: What controls the formation of organic-carbon rich sediments and sedimentary rocks?: American Association of Petroleum Geologists Bulletin, v. 74, no. 4, p. 454-466.

Pozaryska K. and Brochwicz-Lewinski, W., 1975, The nature and origin of Mesozoic and early Cenozoic marine faunal provinces. Some reflections: Mitt. Geol.-Paläont. Inst., Heft 44 , p. 207-216. 
Quenstedt, F. A., 1848-1849, Petrefaktenkunde Deutschlands. I. Cephalopoden, p. 185, pl. V, figs. 10a-b.

Riedel, L., 1938, Amonitas del Cretácico Inferior de la Cordillera Oriental: Estudios Geológicos y Paleontológicos sobre la Cordillera Oriental de Colombia, Ministerio de Industria y Trabajo, Departamento de Minas y Petrología, Bogota, Colombia, Part 2, p. 7 80, láms. 3-14.

Ross, M. A., 1981, Stratigraphy of the Tamaulipas Limestone, Lower Cretaceous, Mexico, in Katz, S. R., and Smith, C. 1, eds., Lower Cretaceous stratigraphy and structure, nothem Mexico, Field Trip Guidebook: West Texas Geological Society, November 11-16, Publication no. 81-74, p. 43-57.

Ryan, W. B., and Cita, M. B., 1977, Ignorance concerning episodes of ocean-wide stagnation: Marine Geology, v. 23, p. 197.215.

Schlanger, S. O., and Jenkyns, H. C., 1976, Cretaceous oceanic anoxic events: Causes and consequences: Geologie en Mijnbouw, v. 55, p. 179-184.

Scott, G., 1940a, Cephalopods from the Cretaceous Trinity Group of the south-central United States: University of Texas, Publication no. 3945, p. 969-1106, pls. 56-70.

Scott, G., 1940b, Paleoecological factors controlling the distribution and mode of life of Cretaceous ammonoids in the Texas area: Joumal of Paleontology, v. 14, no. 4, p. 299 323.

Shimer, H. W., and Shrock, R. R., 1944, Index fossils of North America. Wiley, New York, 837 pp., 303 pls.

Sinzow, I. T., 1906, Die Beschreibung einiger Douvilléiceras-Arten aus dem Oberen Neocom Russlands: Zapiski Imperatorskago S.- Peterburgskago Mineralogicheskago Obshchestva (series 2), v. 44, p. 157-198, fig. 1-5, pls. 1-5. 
Sinzow, I. T., 1907-1908, Untersuchung einiger Ammonitiden aus dem Unteren Gault Mangyschlaks und des Kaukasus: Zapiski Imperatorskago S.- Peterburgskago Mineralogicheskago Obshchestva (series 2), v. 45, p. 455-519, fig. 1-8, pls. 1-8.

Smith, A. G., Hurley, A. M., and Briden, J. C., 1981, Phanerozoic paleocontinental world maps: Cambridge Earth Science Series, Cambridge University Press, Cambridge, $102 \mathrm{pp}$.

Smith, C. I., 1981, Review of the geologic setting, stratigraphy, and facies distribution of the Lower Cretaceous in northern Mexico, in Katz, S. R., and Smith, C. J., eds., Lower Cretaceous stratigraphy and structure, northern Mexico, Field Trip Guidebook: West Texas Geological Society, November 11-16, Publication no. 81-74, p. 1-27.

Sowerby, J. de C., 1836, Appendix A. Descriptive notes respecting the shells figured in plates XI-XXII, in Fitton, W. H., ed., Observations on some of the strata between the Chalk and the Oxford Oolite in the South East of Fngland: Transactions of the Geological Society of London, ser. 2, v. 4, p. 335-349.

Spath, L. F., 1922, On Cretaceous Ammonoidea from Angola, collected by Professor J. W. Gregory: Transactions of the Royal Society of Edinburgh, v. 53, Pt. 6, p. 91-160, pls. $1-4$.

Spath, L. F., 1923-1943, Ammonoidea of the Gault: Paleontographical Society Monographs, 2 vols., 16 pts., 787 pp., 72 pls.

Spath, L. F., 1924, On the ammonites of the Speeton Clay and the subdivisions of the Neocomian: Geological Magazine, v. 61, p. 73-89.

Stoyanow, A., 1949, Lower Cretaceous Stratigraphy in Southeastem Arizona: Geological Society of America, Memoir no. 38,169 pp., 27 pl., 2 figs., 7 tabl.

Tardy, M., 1980, La transversal de Guatemala y la Sierra Madre de México: J. Aubouin, Tratado de Geología, v. III Tectónica y Tectonofísica, y Morfología, Omega, España, p. $117-182$. 
Tatsumi, Y., Shinjoe, H., Ishizuka, H., Sager, W. W., and Klaus, A., 1998, Geochemical evidence for a mid-Cretaceous superplume: Geology, v. 26, p. 151-154.

Toucas, A., 1888, Note sur le Jurassique supérieur et le Crétacé inférieur de la vallée du Rhône: Bulletin Société Géologique de France, v. 16, n. 3, 903 pp.

Trejo, M., 1975, Zonificación del límite Aptiano-Albiano de México: Revista del Instituto Mexicano del Petróleo, v. VII, no. 3, p. 6*29, 5 láms.

Uhlig, V., 1883, Die Cephalopodenfauna der Wernsdorfer Schichten: Denkschriften der Kaiserlichen Akademie der Wissenschaften, Wien, Mathematisch-Naturwissenschaftiche Klasse 46, p. 127-290, 32 plates.

Vail, P. R., Mitchum Jr., R. M., and Thompson, S., 1977, Seismic stratigraphy and global sea level changes, Part 3: American Association of petroleum Geologists, Memoir 26 , p. $63-82$.

Wiedmann, J., 1966, Stammesgeschichte und System der postriadischen Ammonoideen, ein Überblick (2. Teil): Neues Jahrbuch fuer Geologie und Palaeontologie, Abhandlungen, no. 127 , p. $13-81$, fig. $14-47$, pl. $3-6$

Wiedmann, 1., 1973, Evolution or revolution of ammonoids at Mesozoic system boundaries: Biol. Rev., v. 48, p. 159-194.

Wilson, J. L., 1975, Carbonate facies in geologic history. Springer-Verlag, Berlin, Heidelberg, $471 \mathrm{pp}$.

Wilson, J. L., and Pialli, G., 1977, A Lower Cretaceous shelf margin in northern Mexico, in Bebout, D. C., and Loucks, R. G., eds., Cretaceous Carbonates of Texas and MexicoApplications to Subsurface Exploration: University of Texas, Austin, Bureau of Economic Geology, Report of Investigation no. 89, p. 286-294.

Wright, C. W., Calloman, J. H., and Howart, M. K., 1996, Cretaceous Ammonoidea, In: Treatise on Invertebrate Paleontology, Part $L$ (Revised), Mollusca, v. 4, Geological Society of America and University of Kansas Press, 362 pp., 216 figs., 2 tab. 
Wright, R. C., and Hay, W. W., 1969, The abundance of foraminifers in a back-reef environment, Molasses Reef, Florida: Miami Geological Society Memoir 1, A Symposium of recent South Florida foraminifera, p. 121-174.

Young, K., 1969, Ammonite zones of northern Chihuahua. In: Guidebook of the border region, Chihuahua and the United States: Northern Mexico Geological Society (Sante Fe), p. $97-101$.

Zeuschner, L., 1856, Geognostische Beschreibung des Liaskalkes in der Tatra und in den angrenzenden Gebirgen: Sitzungsberichte der Kaiserlichen Akademie der Wissenschaften in Wien, no. 19, p. 135-182, 2 pls.

Zittel, K. A. von, 1868, Paleontologische Studien über die Grenzschichten der Jura* und Kreide- Formation im Gebiete der Karpathen, Alpen, und Apenninen, 1. Abteilung, Die Cephalopoden der Stramberger Schichten: Palaeontologische Mittheilungen aus dem Museum des Koeniglich-Bayerischen Staates, v. II, pt. 1, p. 33-118.

Zittel, K. A. von, 1884, Cephalopoda, in Zittel K. A., Handbuch der Palaeontologie, Band 1, Abt. 2, Lief 3: Oldenbourg, Munich \& Leipzig.

Zittel, K. A. von, 1895, Grundzuge der Palaeontologie: Oldenbourg, Munich \& Leipzig, viii +971 pp., 2048 figs. 
APPENDICES

(1 through 4) 
Appendix 1

\section{MICROFACIES PLATES:}

The following section includes plates 1 through 46 , showing textural and compositional characteristics of the typical microfacies subunits at both stratigraphic sequences.

Cupido Formation, Presa Francisco Zarco section (Plates 1-22)

La Peña Formation, Presa Francisco Zarco (Plates 23-36)

Lower Tamaulipas Formation, La Boca Canyon (Plates 37-39)

La Peña Formation, La Boca Canyon (Plates 40-46) 


\section{PLATE 1. Cupido Formation, Presa Francisco Zarco (Subunit PFZ-A)}

Figure 1. Biocalcilutite with quinqueloculinid benthonic foraminifera of the miliolid group. Sample PFZ-29 a.

Figure 2. Biocalcilutite with ostracod fragment and terrigenous materials.

Sample PFZ-30a.

Figure 3. Echinoid spine. Sample PFZ-29 b.

Figure 4. Recrystallized ostracod. Sample PFZ-30 c.

Figure 5. Planispiral benthonic foraminifera. Sample PFZ-34 a.

Figure 6. Quinqueloculinid miliolid foraminifera. Sample PFZ-34 a.

Figure 7. Textularid benthonic foraminifera. Sample PFZ-34 c.

Figure 8. Biocalcilutite with triloculinid miliolid benthonic foraminifera, intraclasts, and terrigenous materials. Sample PFZ-34 d.

Figure 9. Biocalcilutite with miliolid benthonic foraminifera and terrigenous materials Sample PFZ-34d.

Figure 10. Miliolid foraminifera. Sample PFZ-34 d.

Scale $\mathrm{Bar}=400$ microns for all figures. 
PLATE 1
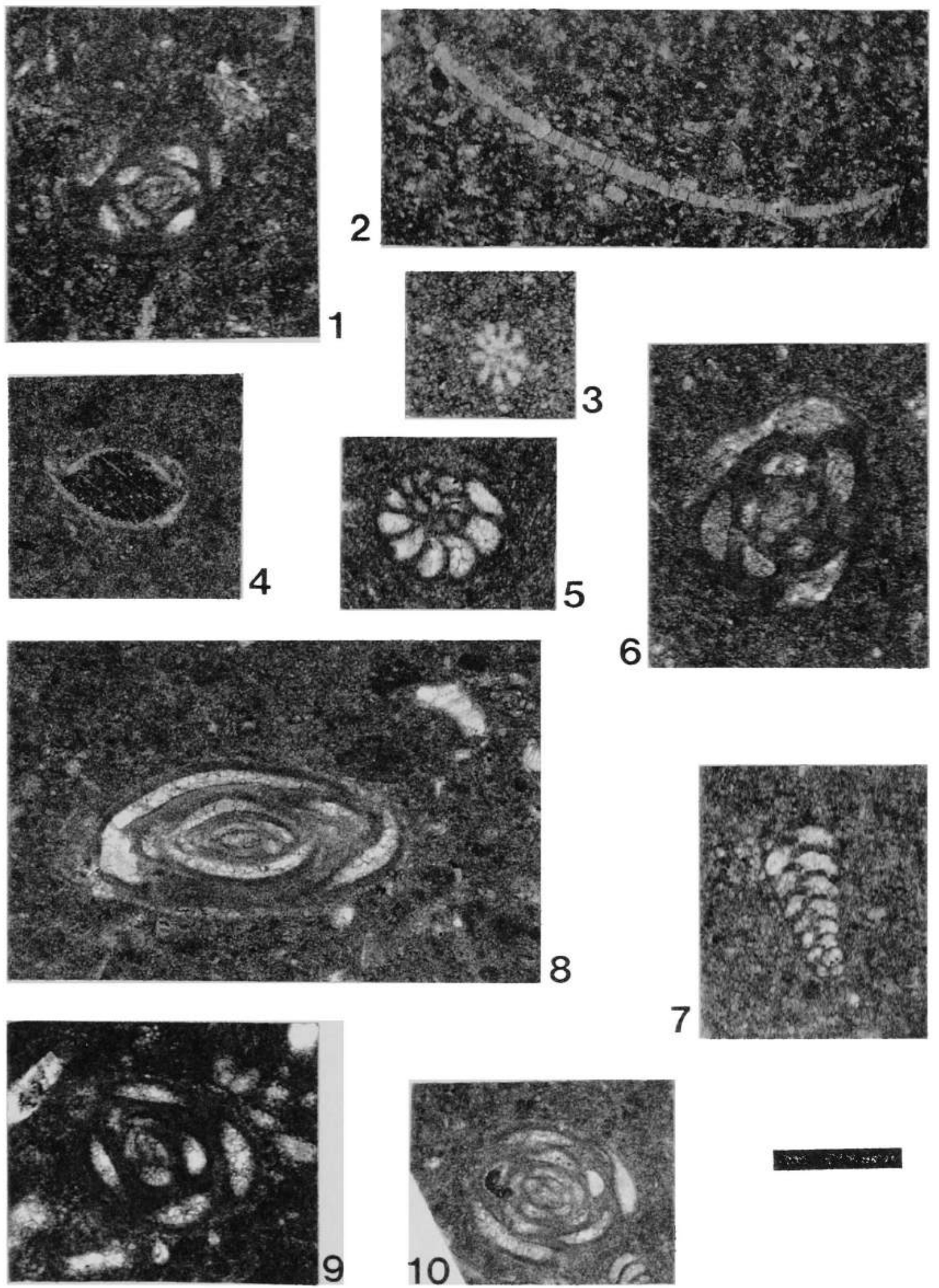


\section{PLATE 2. Cupido Formation, Presa Francisco Zarco (Subunit PFZA)}

Figure 1. Biosparite with benthonic foraminifera, ostracod fragments, and terrigenous materials. Sample PFZ-35.

Figure 2. Biocalcilutite with benthonic foraminifera and pellets. Sample PFZ $Z-35$.

Figure 3. Biocalcilutite with benthonic foraminifera, ostracod fragments, and terrigenous materials. Sample PFZ-37 b.

Figure 4. Miliolid foraminifera. Sample PFZ-37 b.

Figure 5. Recrystallized ostracod in microsparitic matrix. Sample PFZ-39.

Figure 6. Miliolid foraminifera. Sample PFZ 40 a.

Figure 7. Quinqueloculinid miliolid foraminifera. Sample PFZ 40 a.

Figure 8. Biocalcilutite with quinqueloculinid miliolid benthonic foraminifera, echinoid and crinoid fragments. Sample PFZ-40 b.

Figure 9. Quinqueloculinid miliolid foraminifera. Sample PFZ 40 b.

Scale $B a r=400$ microns for all figures. 

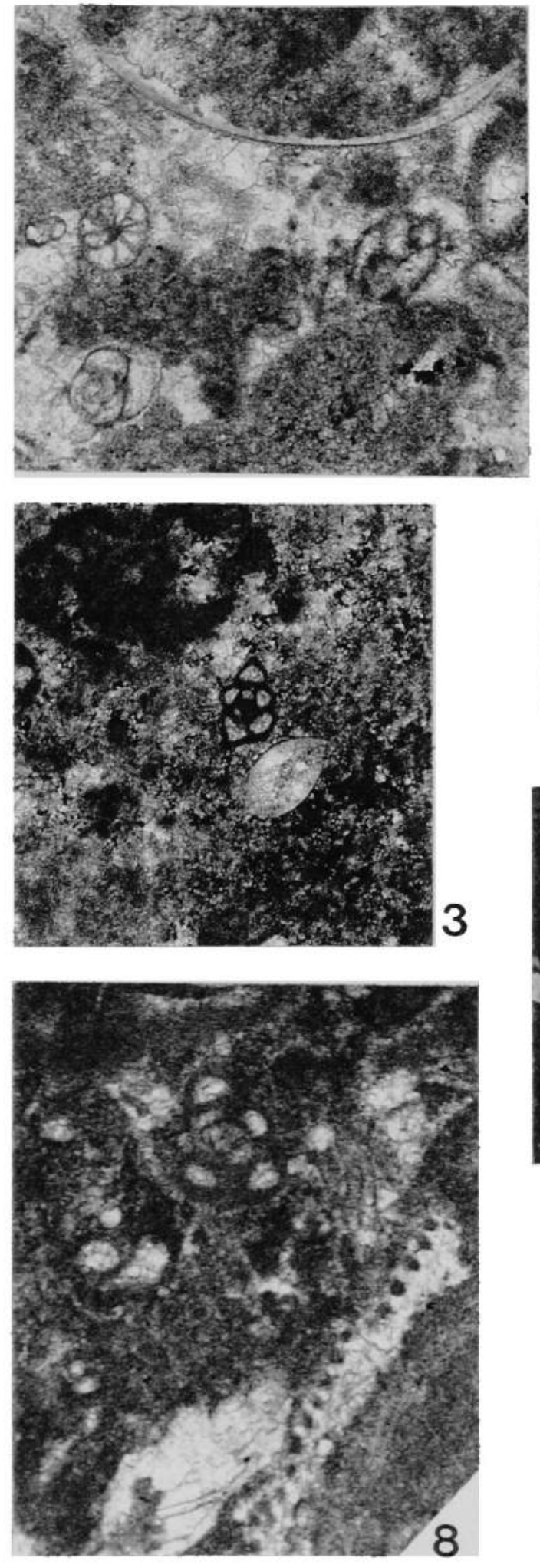
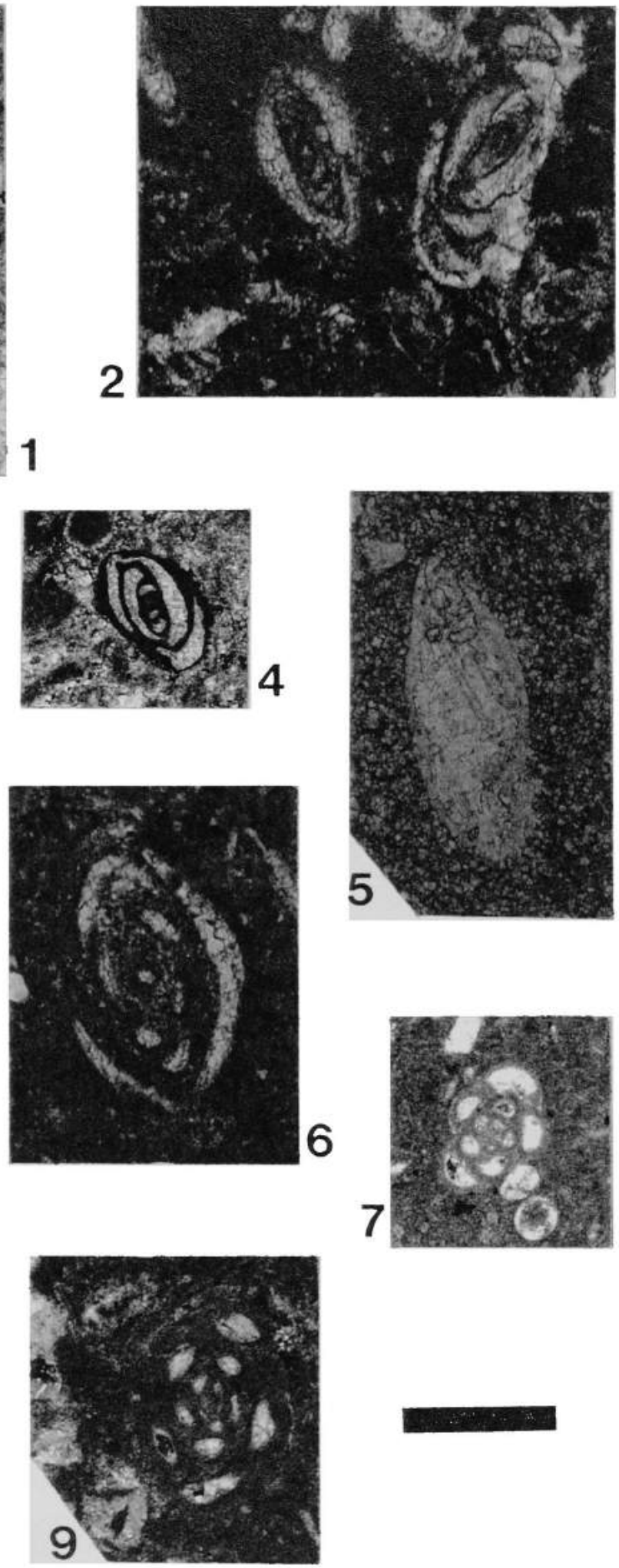
PLATE 3. Cupido Formation, Presa Francisco Zarco (Subunits PFZ-A and PFZ-B)

Figure 1. Biocalcilutite with miliolid benthonic foraminifera, mollusk and echinoid fragments, and terrigenous materials. Subunit PFZ-A, Sample PFZ 40 b.

Figure 2. Biocalcilutite with miliolid benthonic foraminifera, intraclasts, and mollusk fragments. Subunit PFZ-A, Sample PFZ43 b.

Figure 3. Biocalcilutite with recrystallized mollusk fragments. Subunit PFZ-A, Sample PFZ-43 c.

Figure 4. Pelloidal calcarenite with mollusk, echinoid, and crinoid fragments, and displaying patches of sparry calcite cement. Subunit PFZ-B, Sample PFZ-44 b.

Scale Bar $=1000$ microns for all figures. 


\section{PLATE 3}
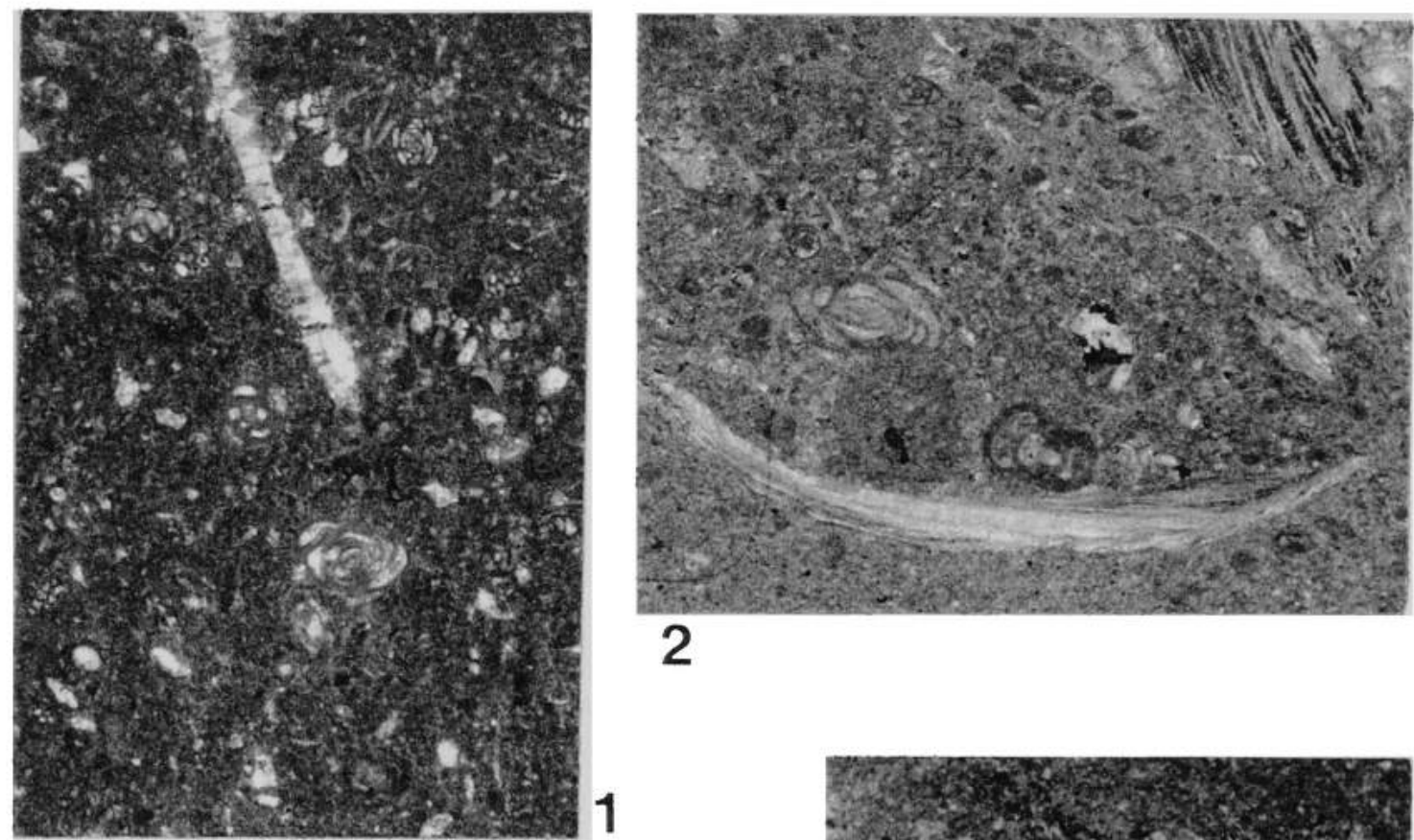

2
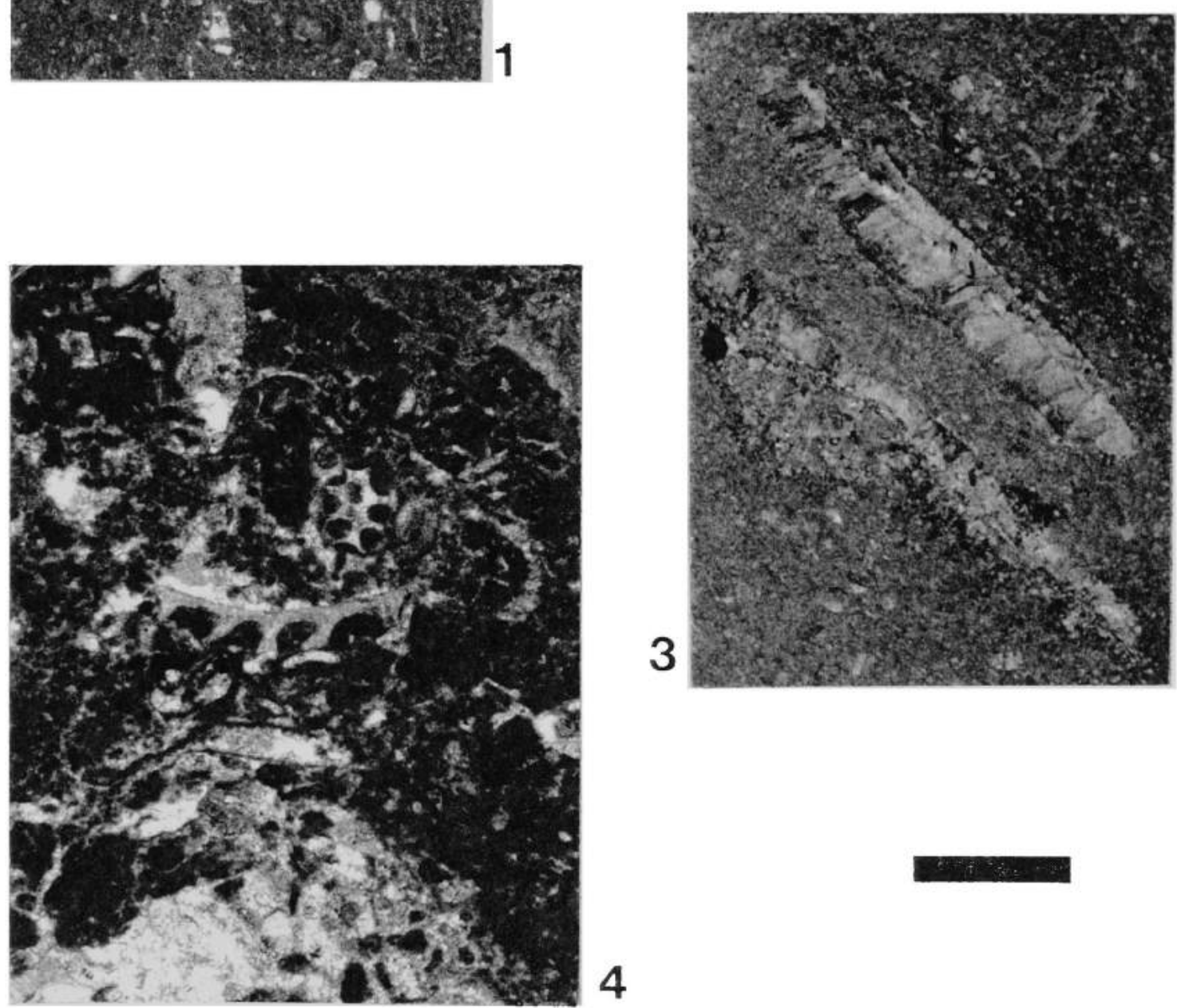

4 
Figure 1. Bryozoan skeletal fragment. Sample PFZ-44 b.

Figure 2. Miliolid-pelloidal calcarenite, with intraclasts, mollusk and echinoid fragments Sample PFZ- $44 \mathrm{c}$.

Figure 3. Bioturbated pelletoidal calcarenite with intraclasts, miliolid foraminifera, and echinoid fragments. Note secondary sparry calcite cement in bioturbated areas. Sample PFZ-45 a.

Figure 4. Bioturbated pelloidal calcarenite with intraclasts, miliolid foraminifera, and echinoid fragments. Note secondary sparry calcite cement in bioturbated areas. Sample PFZ 45 a.

Scale $B a r=1000$ microns for all figures. 
PLATE 4
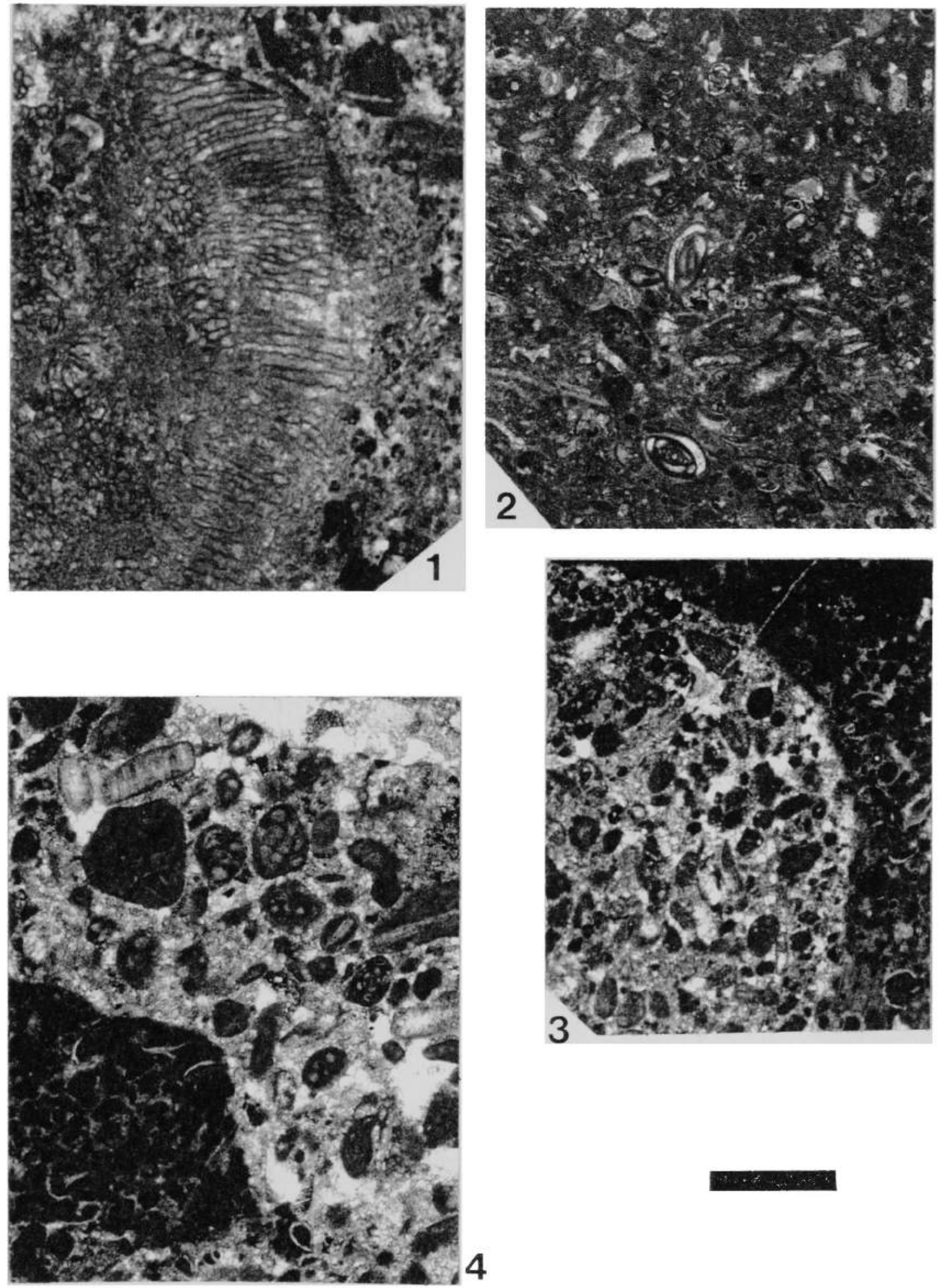
PLATE 5. Cupido Formation, Presa Francisco Zarco (Subunit PFZ-C)

Figure 1. Oolitic biocalcarenite with sparry calcite cement. Sample PFZ-45 b. Scale Bar $=1000$ microns.

Figure 2. Oolitic biocalcarenite with algae and crinoid fragments. Matrix consist of sparry calcite cement. Sample PFZ 45 b. Scale Bar $=1000$ microns.

Figure 3. Oolitic biocalcarenite with ostracod fragments, displaying sparry calcite cement. Sample PFZ 45 b. Scale Bar $=1000$ microns.

Figure 4. Oolite showing radial concentric textural layers, and rimmed by blocky sparry calcite cement. Sample PFZ -45 b. Scale Bar $=400$ microns. 

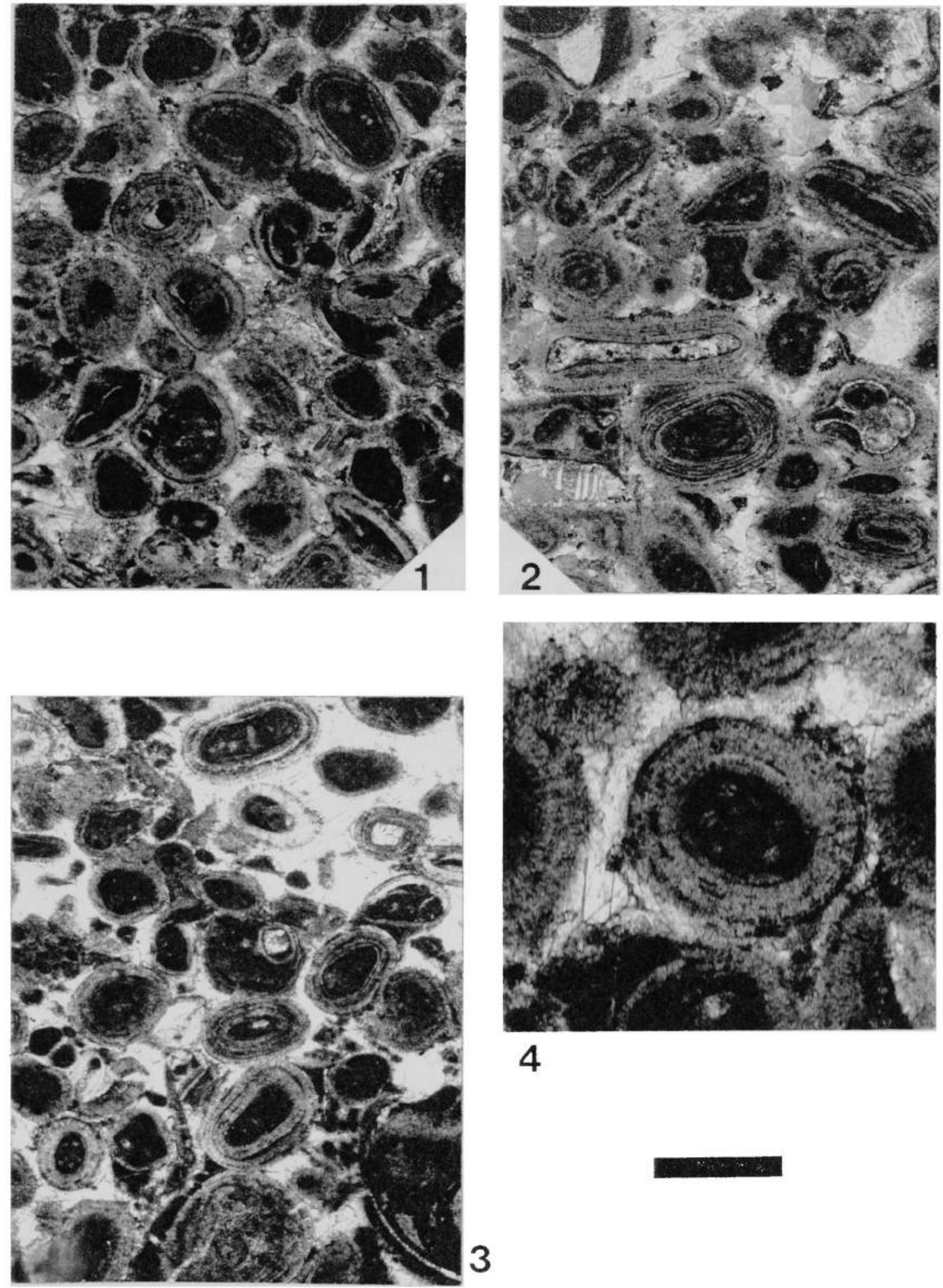

4 
PLATE 6. Cupido Formation, Presa Francisco Zarco (Subunit PFZ-C)

Figure 1. Biocalcarenite with oolites and algal fragments displaying blocky sparry calcite cement. Note that most oolite nuclei consist of miliolid benthonic foraminifera Sample PFZ 45 c. Scale Bar $=1000$ microns.

Figure 2. Biocalcarenite with oolites, and algal fragments and pellets. Matrix consist of sparry calcite cement. Sample PFZ-45 c. Scale Bar $=1000$ microns.

Figure 3. Biocalcarenite with oolites, algal fragments and pellets. Matrix consists of sparry calcite cement. Sample PFZ 45 c. Scale Bar $=1000$ microns.

Figure 4. Oolite showing radial concentric textural layers, and rimmed by blocky sparry calcite cement. Note filaments of algal fragments rimmed by smaller blocks of microsparitic calcite. Sample PFZ $45 \mathrm{c}$. Scale $\mathrm{Bar}=400$ microns. 
PLATE 6
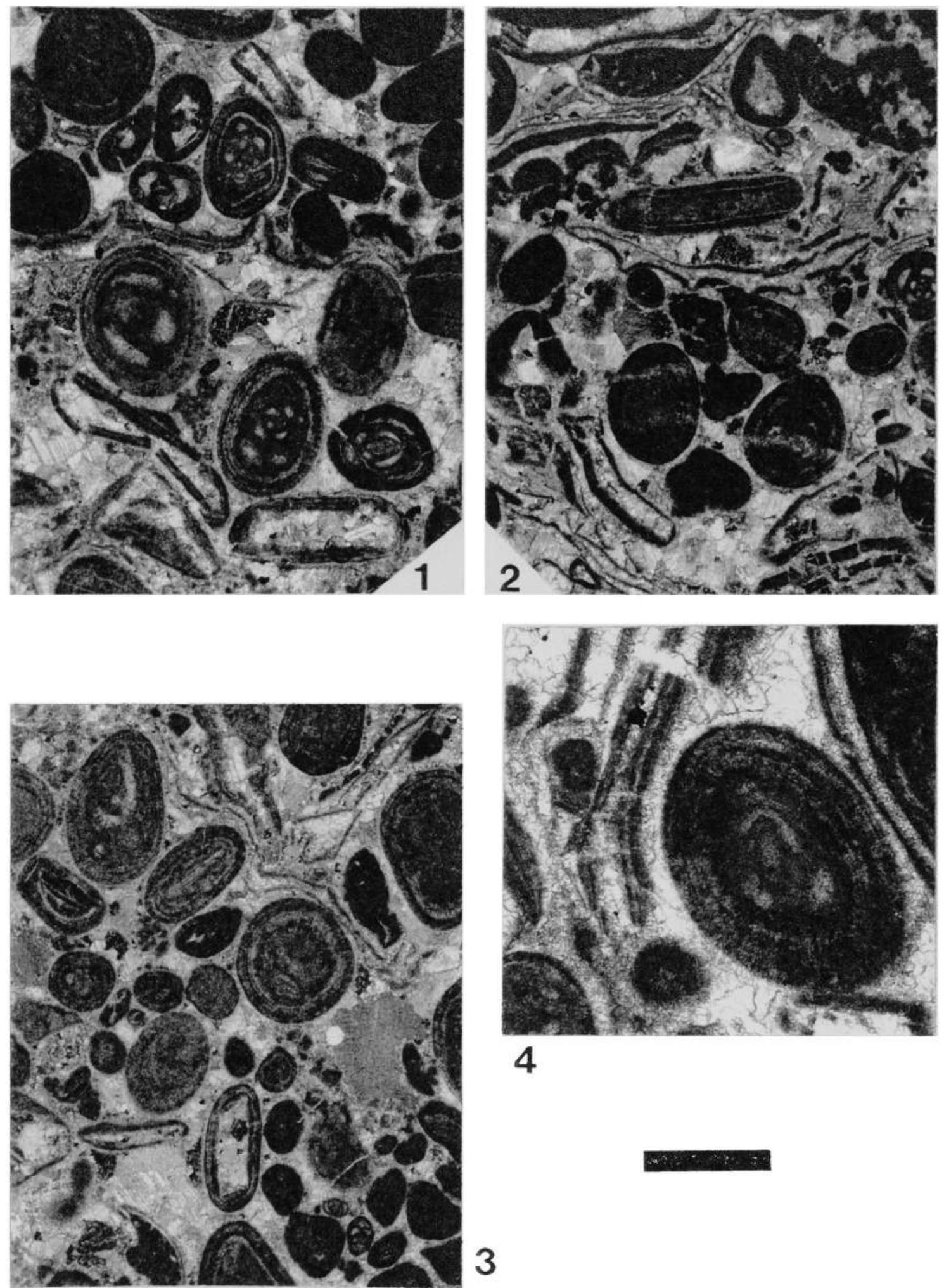
PLATE 7. Cupido Formation, Presa Francisco Zarco (Subunit PFZ-D, Sample 46 b)

Figure 1. Matrix-supported biocalcindite with rudist fragments randomly oriented, intraclasts, and mollusk fragments. Note patches of sparry calcite cement. Sample 46 b. Scale Bar $=2000$ microns.

Figure 2. Matrix-supported biocalcirudite with rudist fragments randomly oriented, intraclasts, and mollusk fragments. Note patches of sparry calcite cement. Sample 46 b. Scale Bar $=2000$ microns.

Figure 3. Close-up of the same sample, showing rudist fragments and miliolid foraminifera. Sample 46 b. Scale Bar $=400$ microns.

Figure 4. Close-up of the same sample, showing a quiqueloculinid benthonic miliolid foraminifera. Sample 46 b. Scale Bar $=400$ microns. 


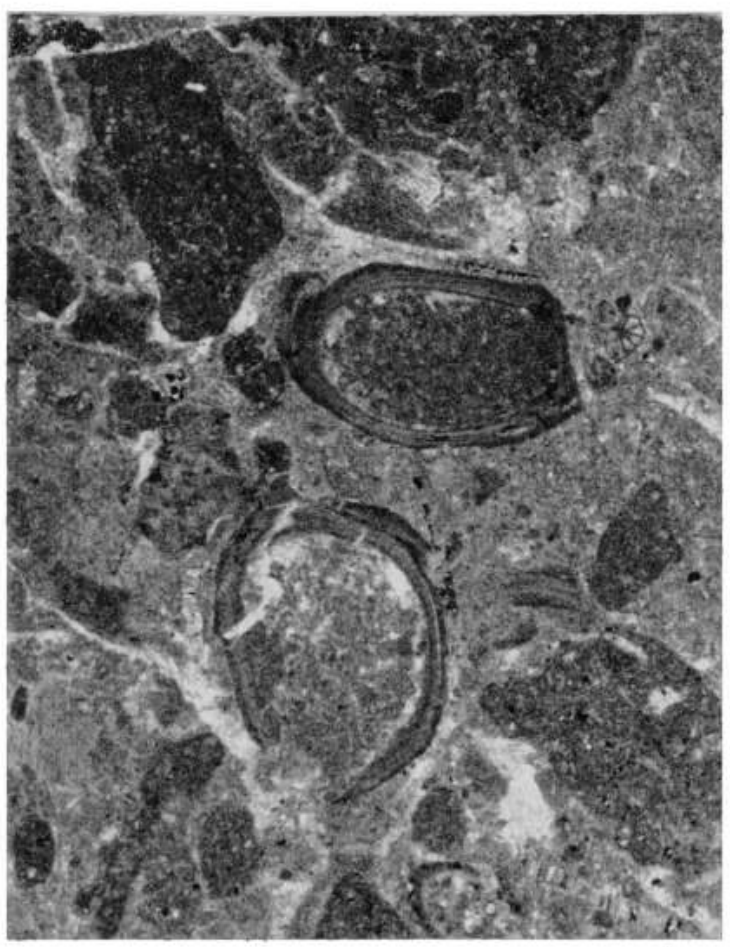

1

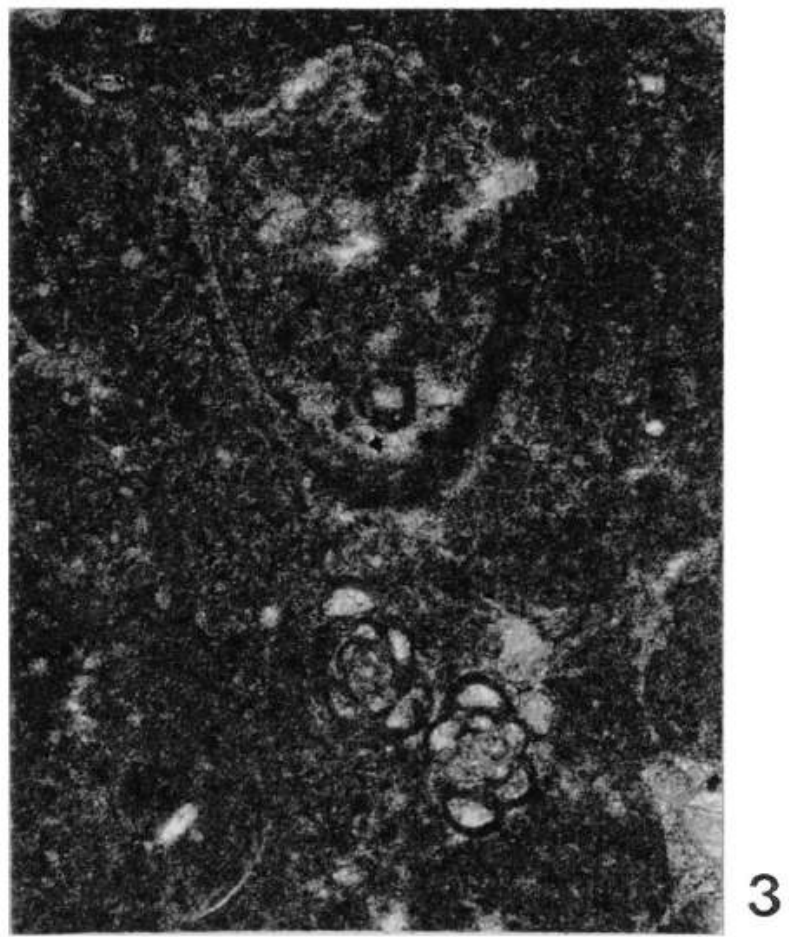

3
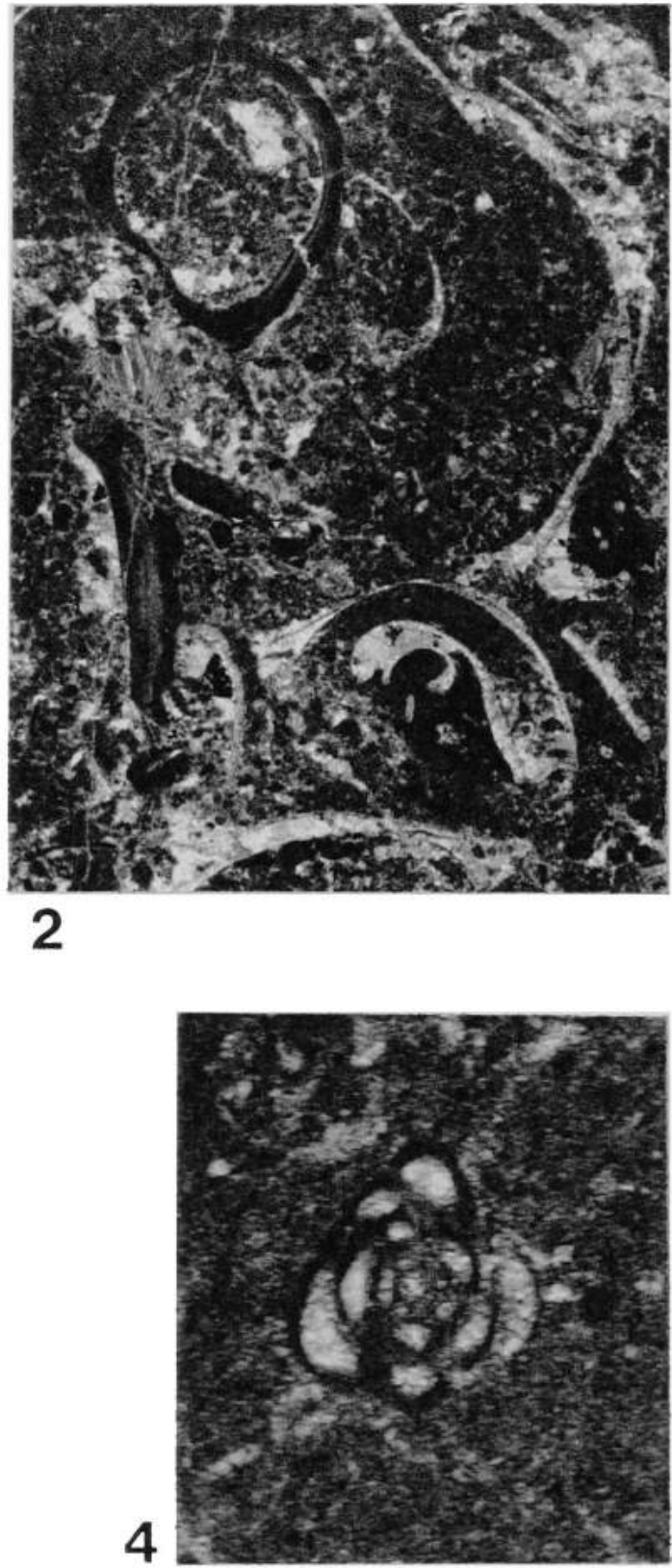
PLATE 8. Cupido Formation, Presa Francisco Zarco (Subunit PFZ-D,

\section{Sample $46 \mathrm{c}$ )}

Figure 1. Pelletoidal calcarenite with scarce benthonic foraminifera. Matrix of this area of the sample consists of sparry calcite cement.

Sample $46 \mathrm{c}$. Scale Bar $=800$ microns.

Figure 2. Pelloidal calcarenite with scarce benthonic foraminifera. Matrix of this area of the sample mainly consists of micritic calcite cement. Sample $46 \mathrm{c}$. Scale Bar $=800$ microns.

Figure 3. Close-up of the same sample, showing pellets. Sample $46 \mathrm{c}$. Scale Bar $=400$ microns.

Figure 4. Close-up of the same sample, showing pellets and blocky sparry cement. Sample $46 \mathrm{c}$. Scale Bar $=400$ microns. 


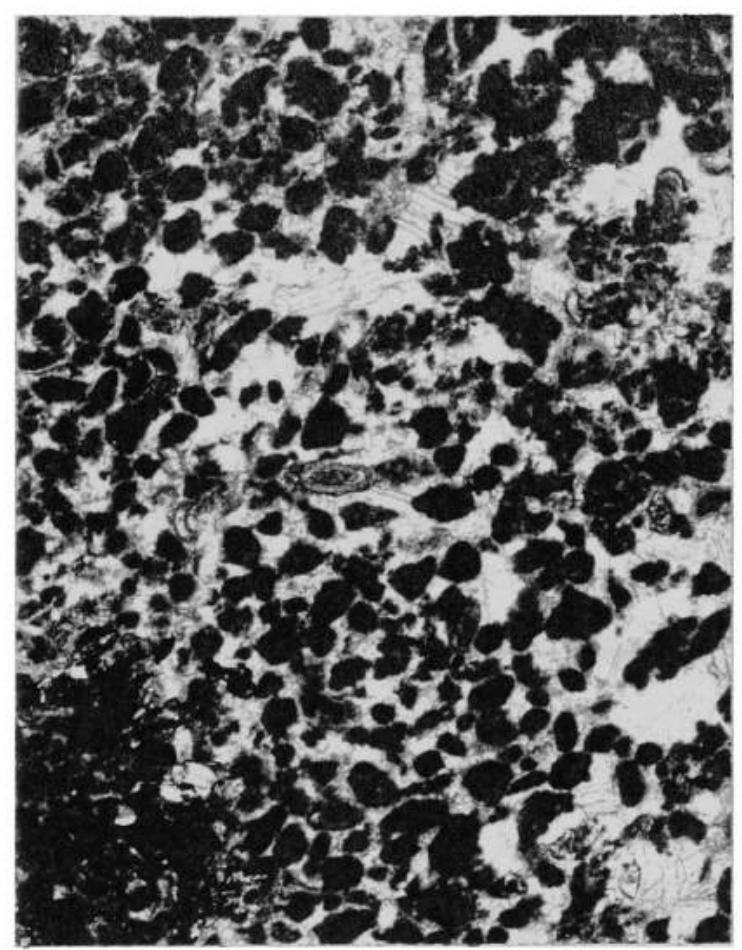

1

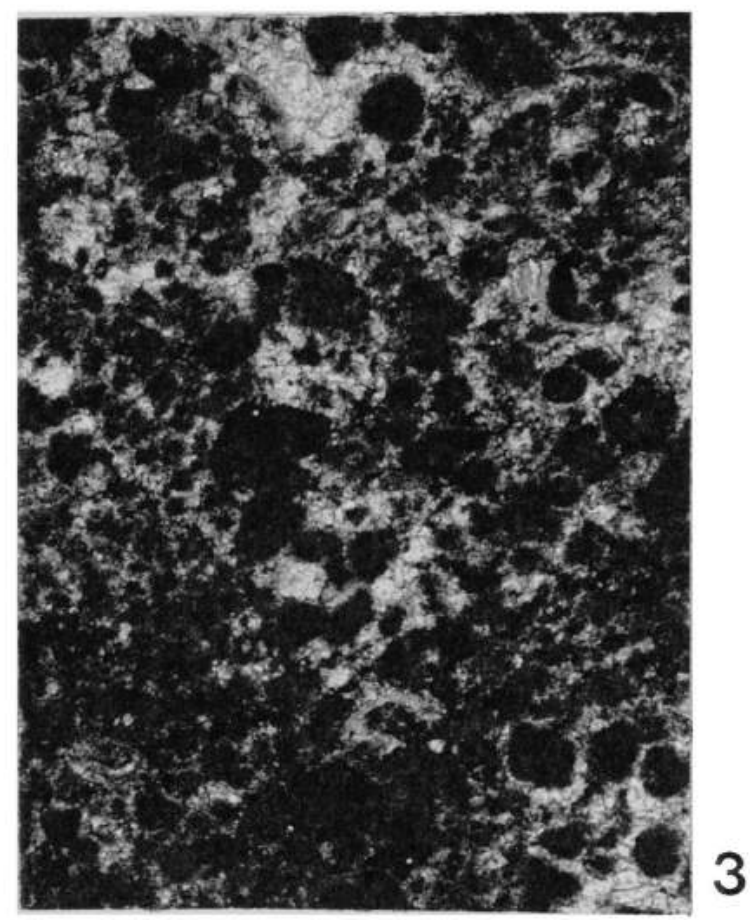

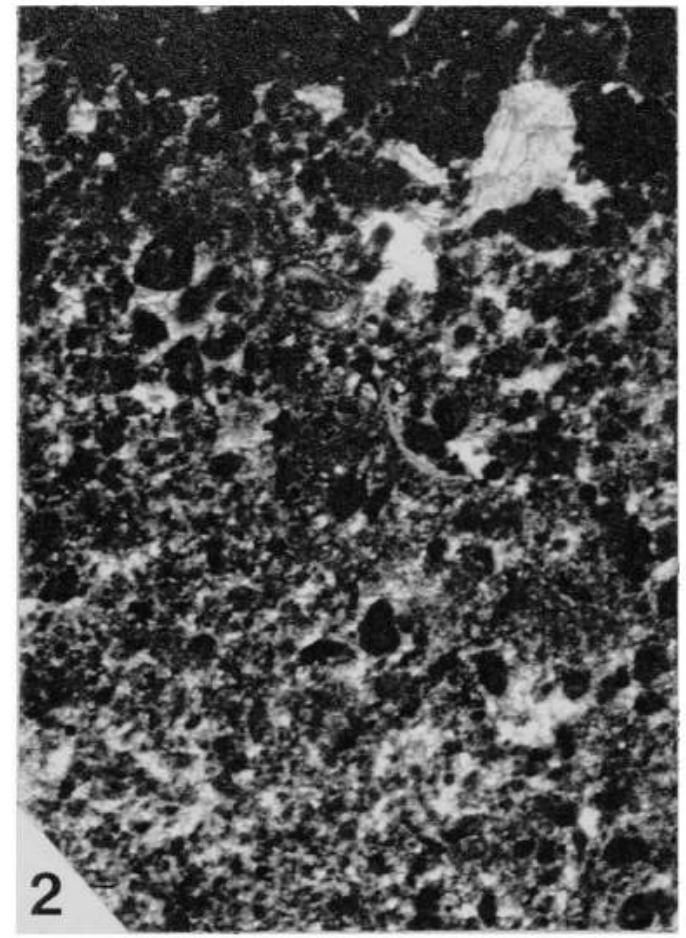

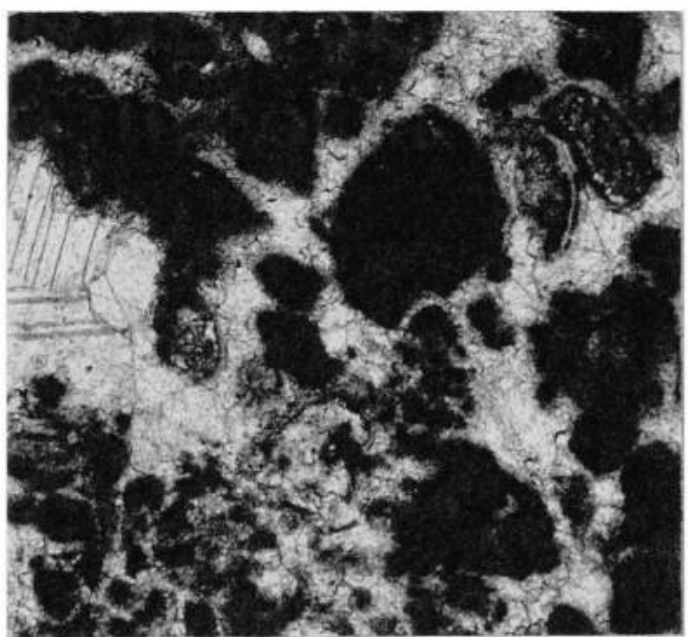

4 
PLATE 9. Cupido Formation, Presa Francisco Zarco (Subunit PFZ-D-upper part)

Figure 1. Biocalcilutite containing benthonic foraminifera of the miliolid group, intraclasts, and terrigenous materials. Note that some areas display microsparitic cement. Sample PFZ- 47 a.

Figure 2. Partially dolomitic biocalcilutite. Note thombic crystals of dolomite. The bioclast at the center is a quinqueloculinid miliolid foraminifera. Sample PFZ 47 b.

Figure 3. Biocalcilutite with benthonic foraminifera, recrystallized mollusk and echinoid fragments, and terrigenous materials. Matrix mainly consists of micritic calcite. Sample PFZ- 48.

Figure 4. Close-up of the previous sample. Sample PFZ-48.

Scale Bar $=800$ microns for all figures. 


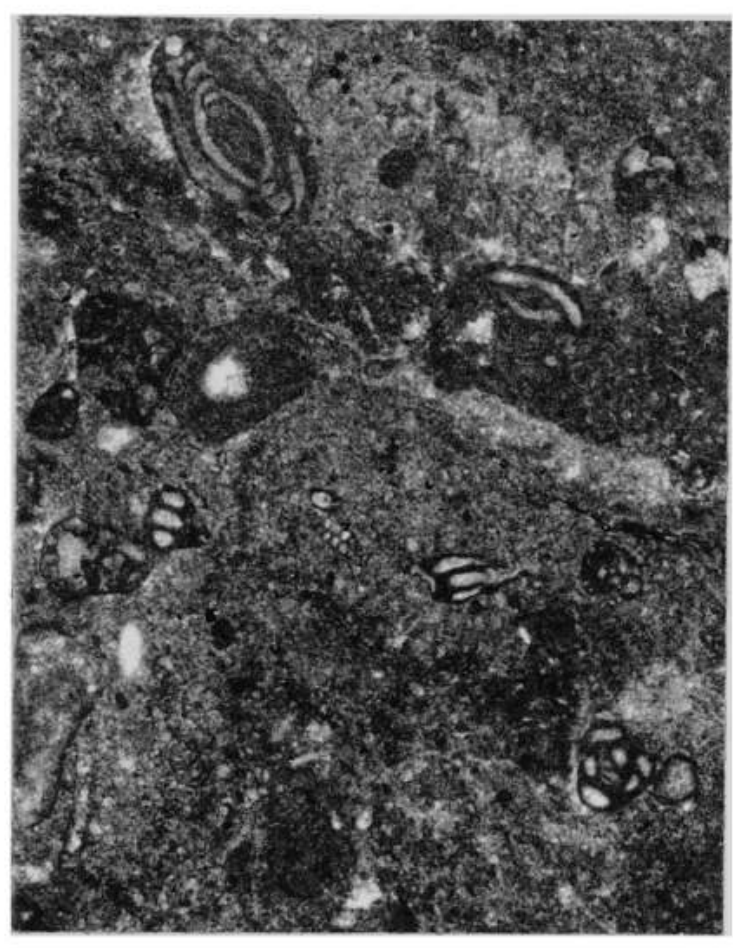

1

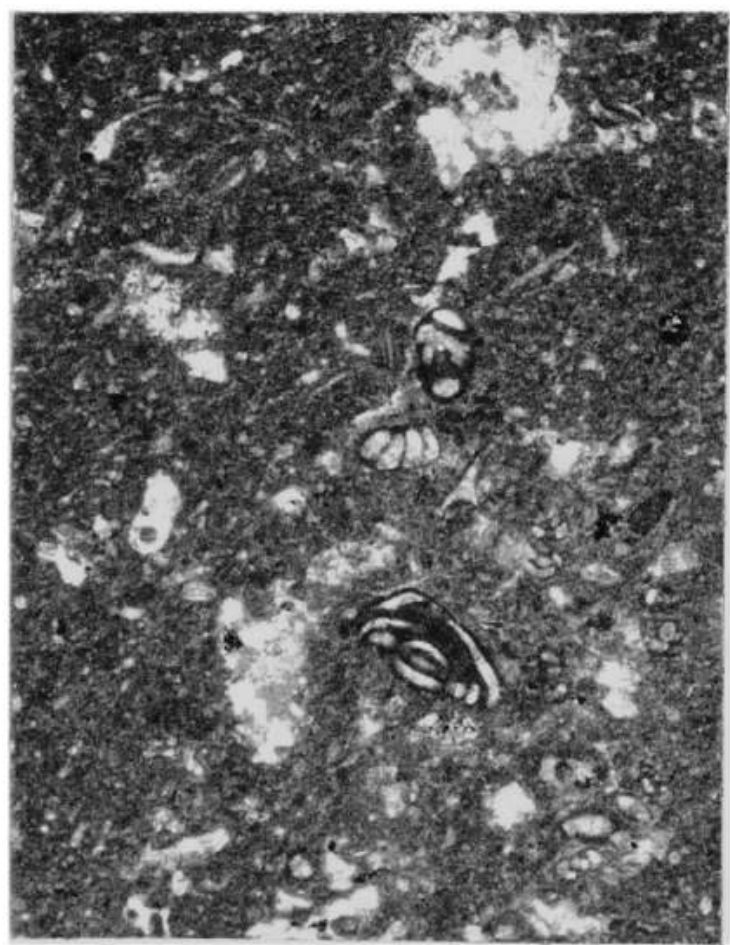

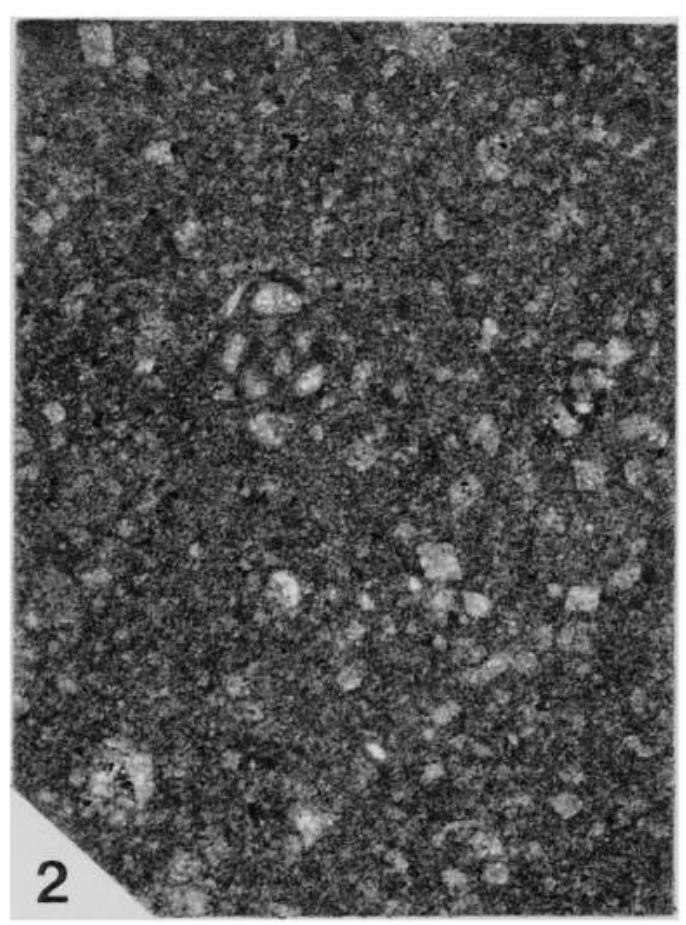

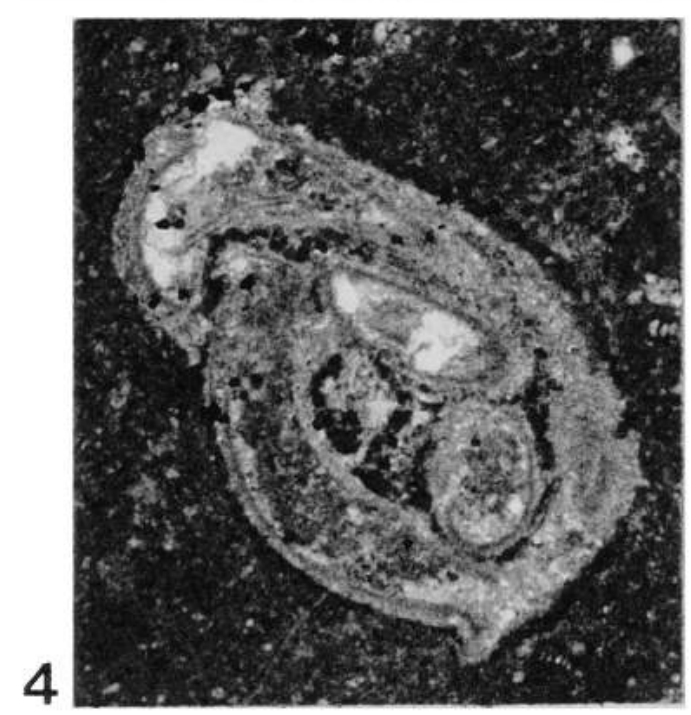

3 
PLATE 10. Cupido Formation, Presa Francisco Zarco (Subunit PFZ-Dupper part, sample PFZ 48)

Figure 1. Close-up of a rudist fragment. Note crystals of blocky calcite that infills the cavity of the rudist. Sample PFZ-48.

Figure 2. Close-up of a rudist fragment in a micritic matrix. Sample PFZ-48.

Figure 3. Side view of a benthonic foraminifera (Orbitolina sp.). Sample PFZ-48.

Figure 4. Frontal view of a benthonic foraminifera of the orbitolinid group. Sample PFZ48.

Figure 5. Biocalcilutite showing a benthonic foraminifera of the Orbitolina group and some terrigenous components. Sample PFZ-48.

Scale Bar $=1000$ microns for all figures. 

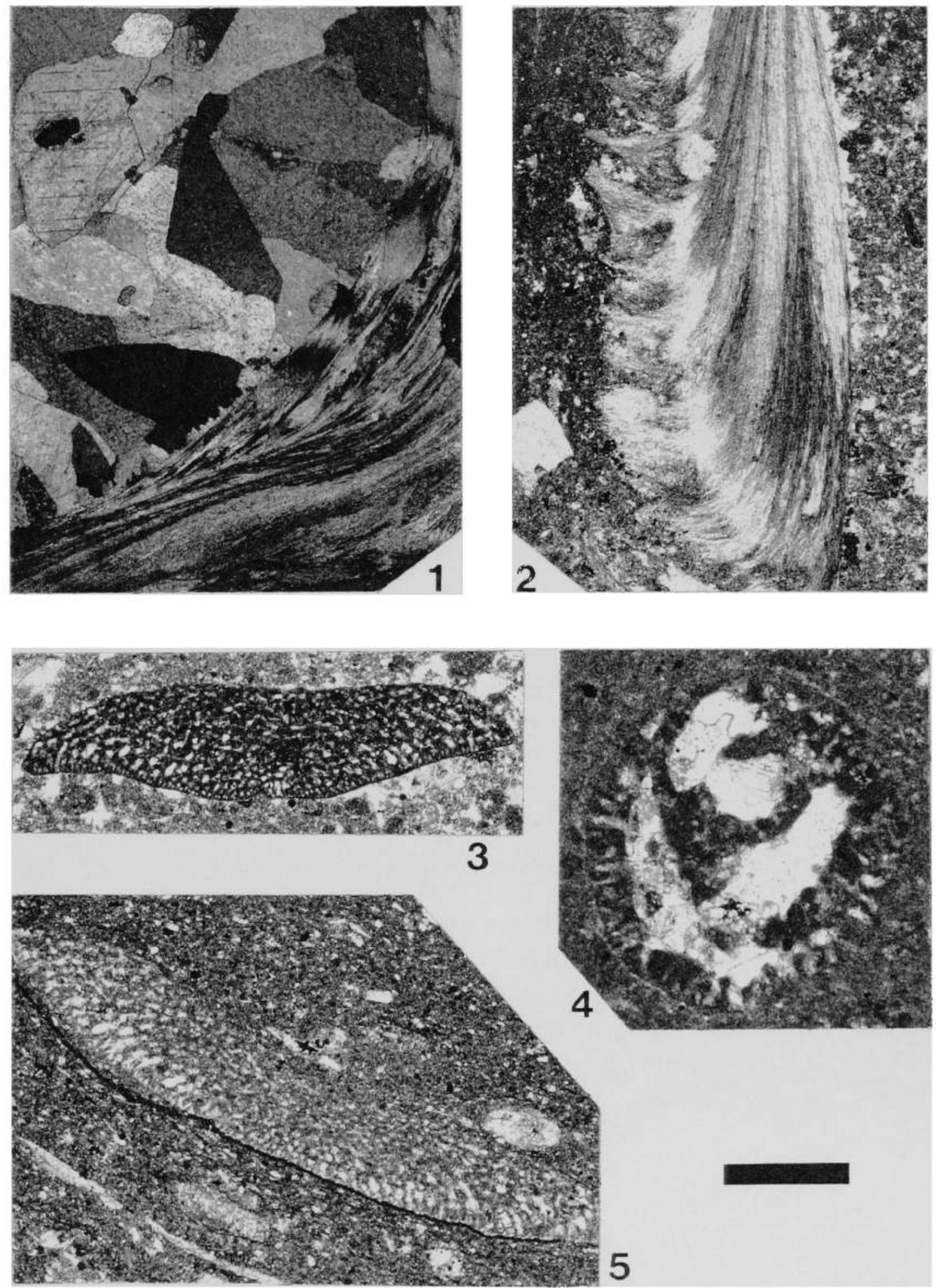
PLATE 11, Cupido Formation, Presa Francisco Zarco (Subunit PFZ-D-

upper part)

Figure 1. Biocalcilutite with benthonic foraminifera of the orbitolinid group, mollusk fragments, and terrigenous. Sample PFZ-49.

Figure 2. Echinoid biocalcarenite with pellets and benthonic foraminifera. Sample PFZ-50a.

Figure 3. Echinoid-pelletoidal biocalcarenite. Sample PFZ-5la.

Figure 4. Bioturbated biocalcilutite with intraclasts and benthonic foraminifera. Matrix mainly consists of micrite. Sample PFZ-51b.

Scale Bar $=1000$ microns for all figures. 


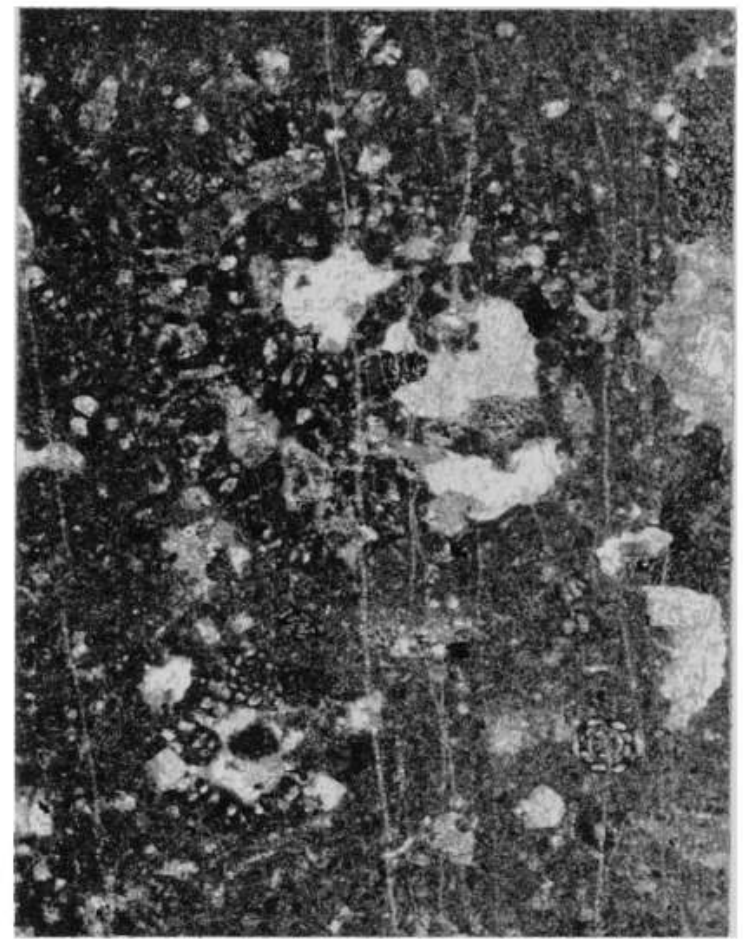

1

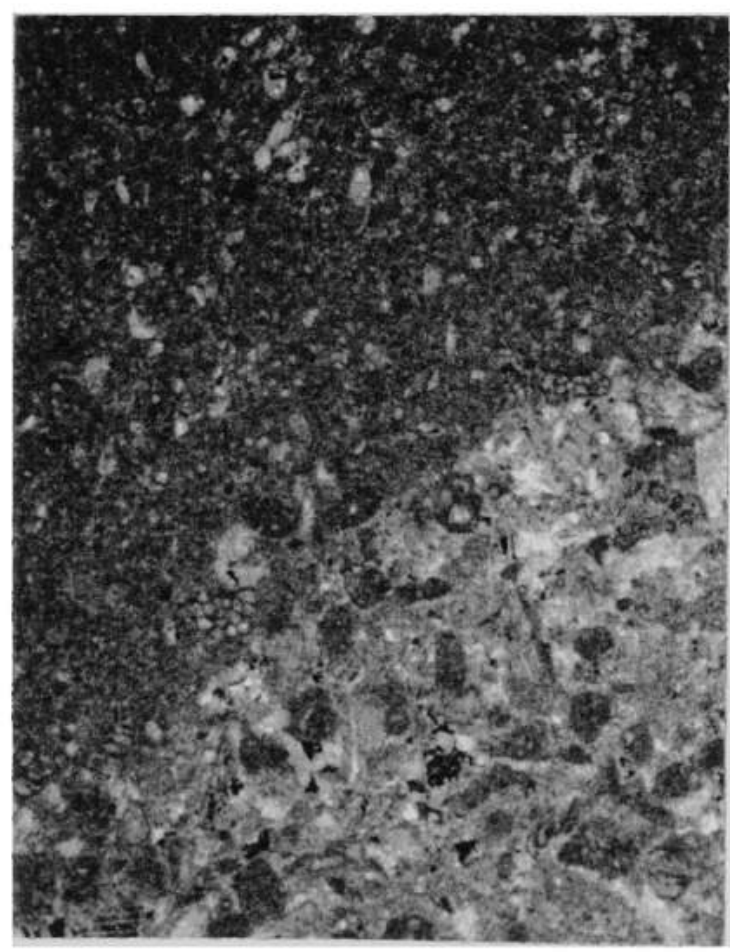

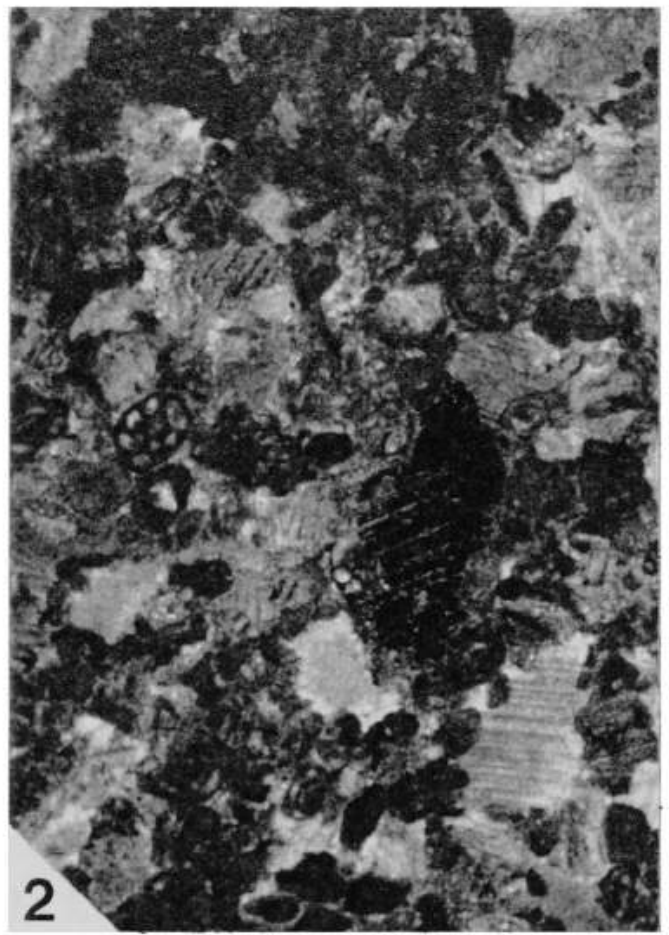

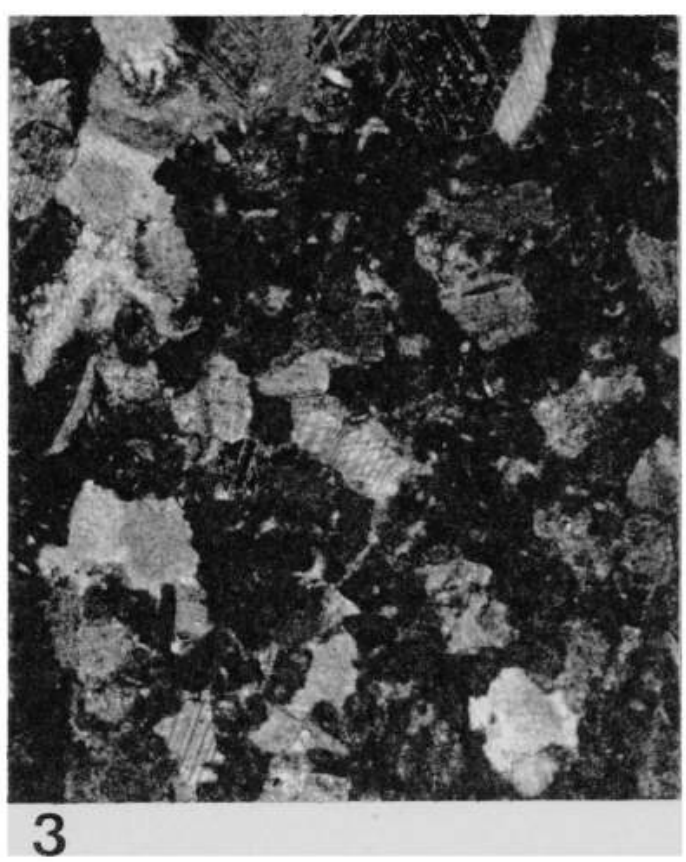

4 
PLATE 12. Cupido Formation, Presa Francisco Zarco (Subunit PFZ-E)

Figure 1. Grain-supported biocalcarenite with pellets, mollusk and echinoid fragments Sample PFZ-52b.

Figure 2. Grain-supported biocalcarenite with pellets, mollusk, echinoid, and crinoid fragments. Sample PFZ $52 \mathrm{c}$.

Figure 3. Grain-supported biocalcarenite with pellets, benthonic foraminifera, and mollusk, echinoid, and crinoid fragments. Note patches of sparry calcite cement. Sample PFZ-52c.

Figure 4, Grain-supported pelloidal-benthonic foraminifera biocalcarenite. Sample PFZ 53.

Scale Bar $=1000$ microns for all figures. 

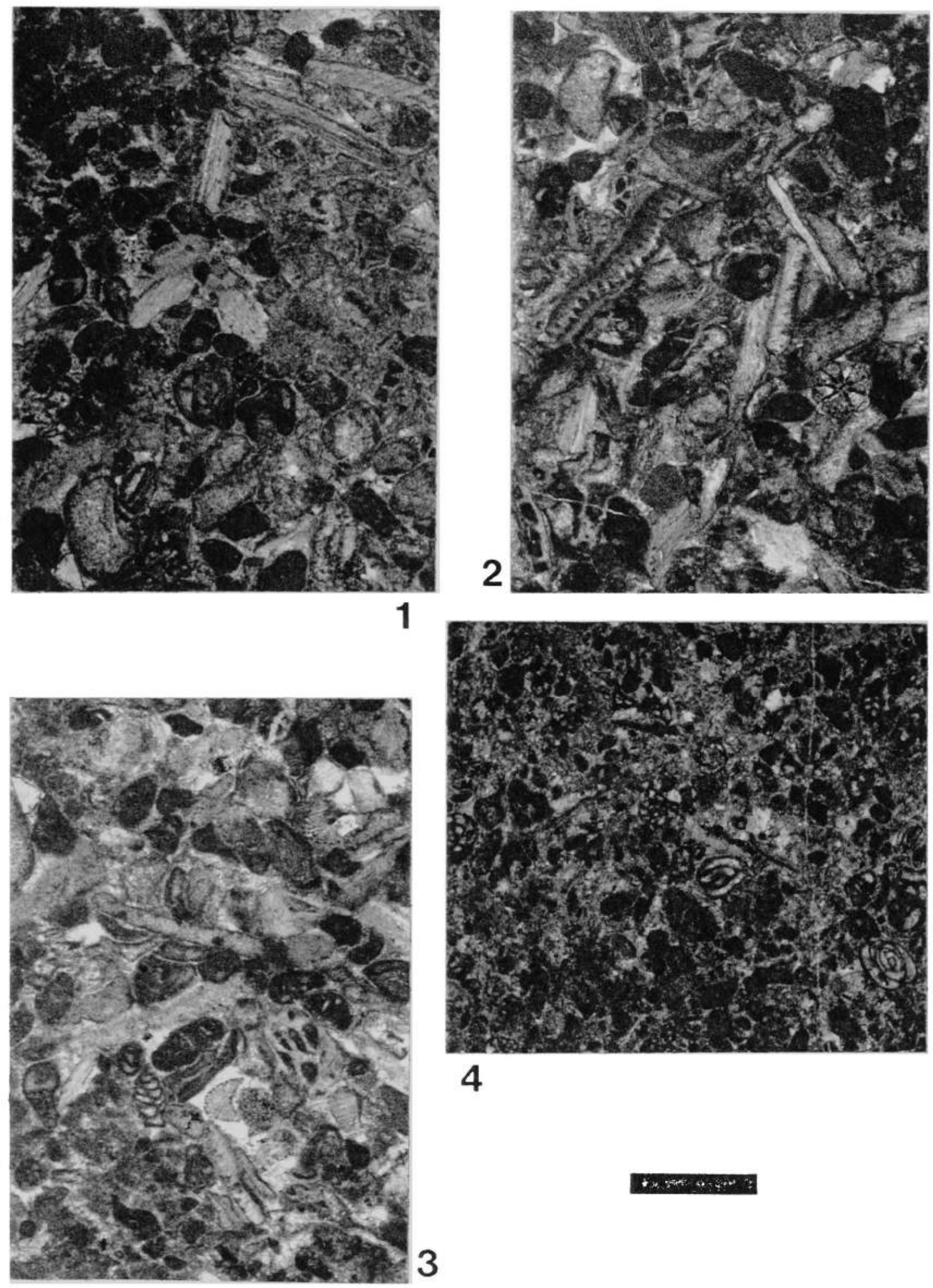
PLATE 13. Cupido Formation, Presa Francisco Zarco (Subunits PFZ-F and PFZ-G)

Figure 1. Dolostone. Note rhombic crystals of dolomite. Sample PFZ-54a. Scale $\mathrm{Bar}=400$ microns.

Figure 2. Dolostone. Note rhombic crystals of dolomite. Sample PFZ-56. Scale Bar $=400$ microns.

Figure 3. Intraclastic-pelloidal biocalcarenite with benthonic foraminifera, terrigenous materials. Sample PFZ-57a. Scale Bar $=1000$ microns.

Figure 4. Close-up of previous sample showing benthonic foraminifera of the miliolid group and pellets. Sample PFZ-57a. Scale Bar $=400$ microns. 
PLATE 13

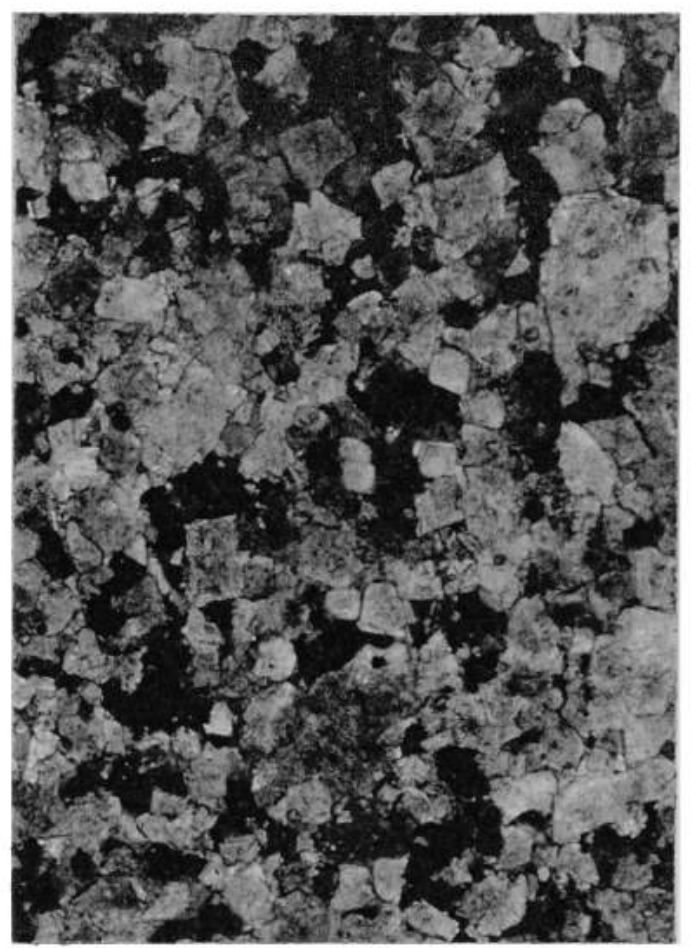

1

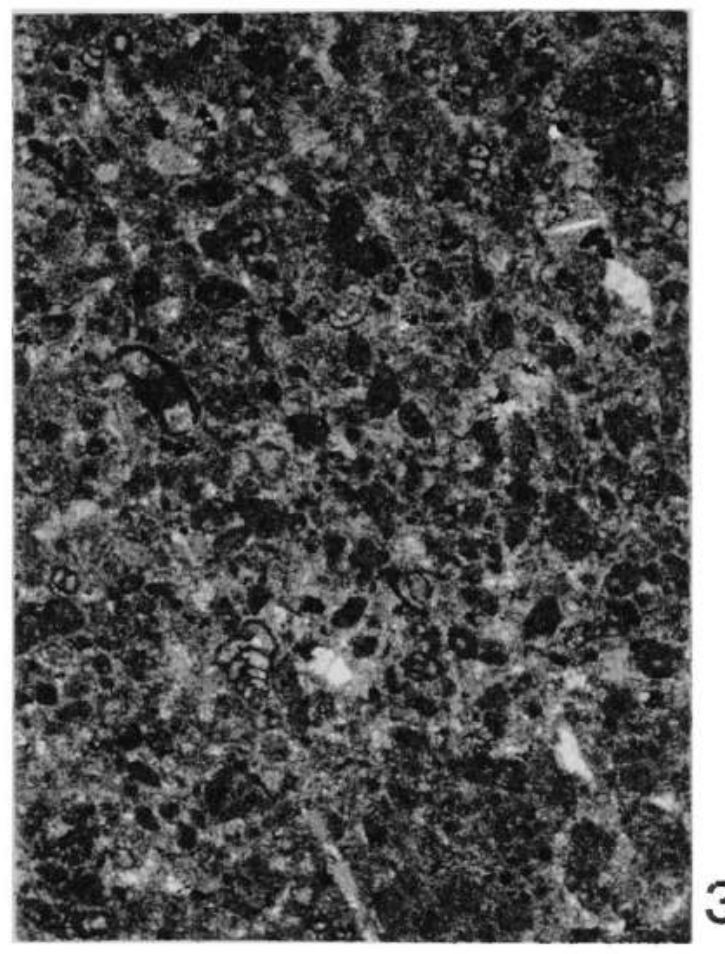

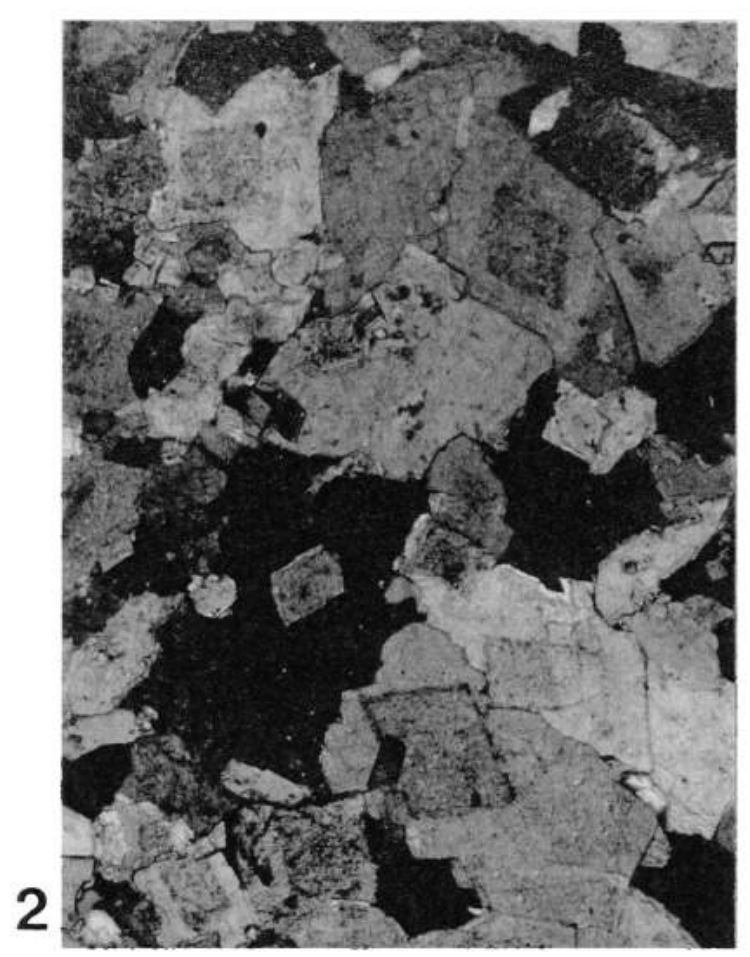

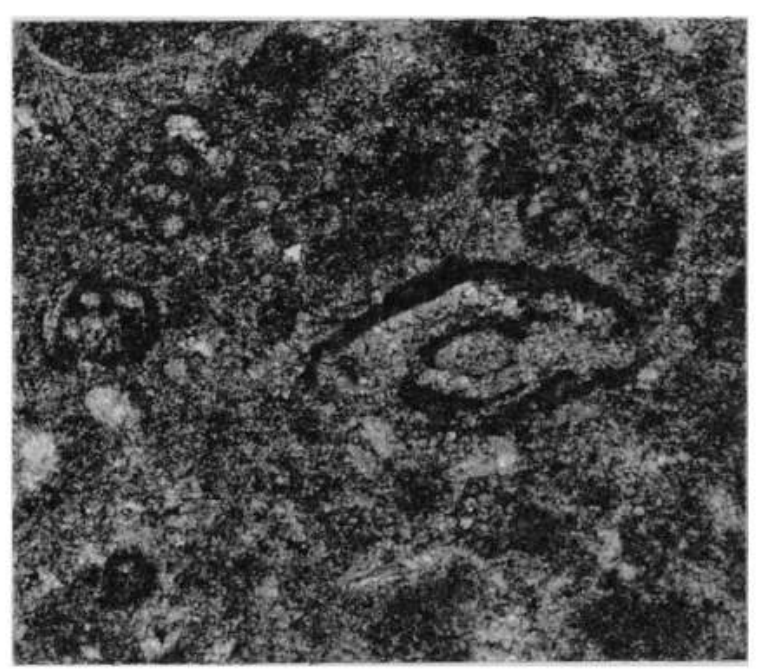

4 


\section{PLATE 14. Cupido Formation, Presa Francisco Zarco (Subunit PFZ-G)}

Figure 1. Biocalcilutite with benthonic foraminifera, pellets, and echinoid fragments. Sample PFZ-57b.

Figure 2. Biocalcilutite with benthonic foraminifera, pellets, and ostracod and echinoid fragment. Note the microsparitic matrix. Sample PFZ-57b.

Figure 3. Ostracod. Sample PFZ-57b.

Figure 4. Biocalcilutite with echinoid and mollusk fragments, pellets, and intraclasts. Sample PFZ-57b.

Figure 5. Echinoid spine. Sample PFZ-57b.

Figure 6. Biserial benthonic foraminifera?. Sample PFZ-57c.

Figure 7. Trochospiral foraminifera. Sample PFZ-57c.

Scale Bar $=400$ microns for all figures. 

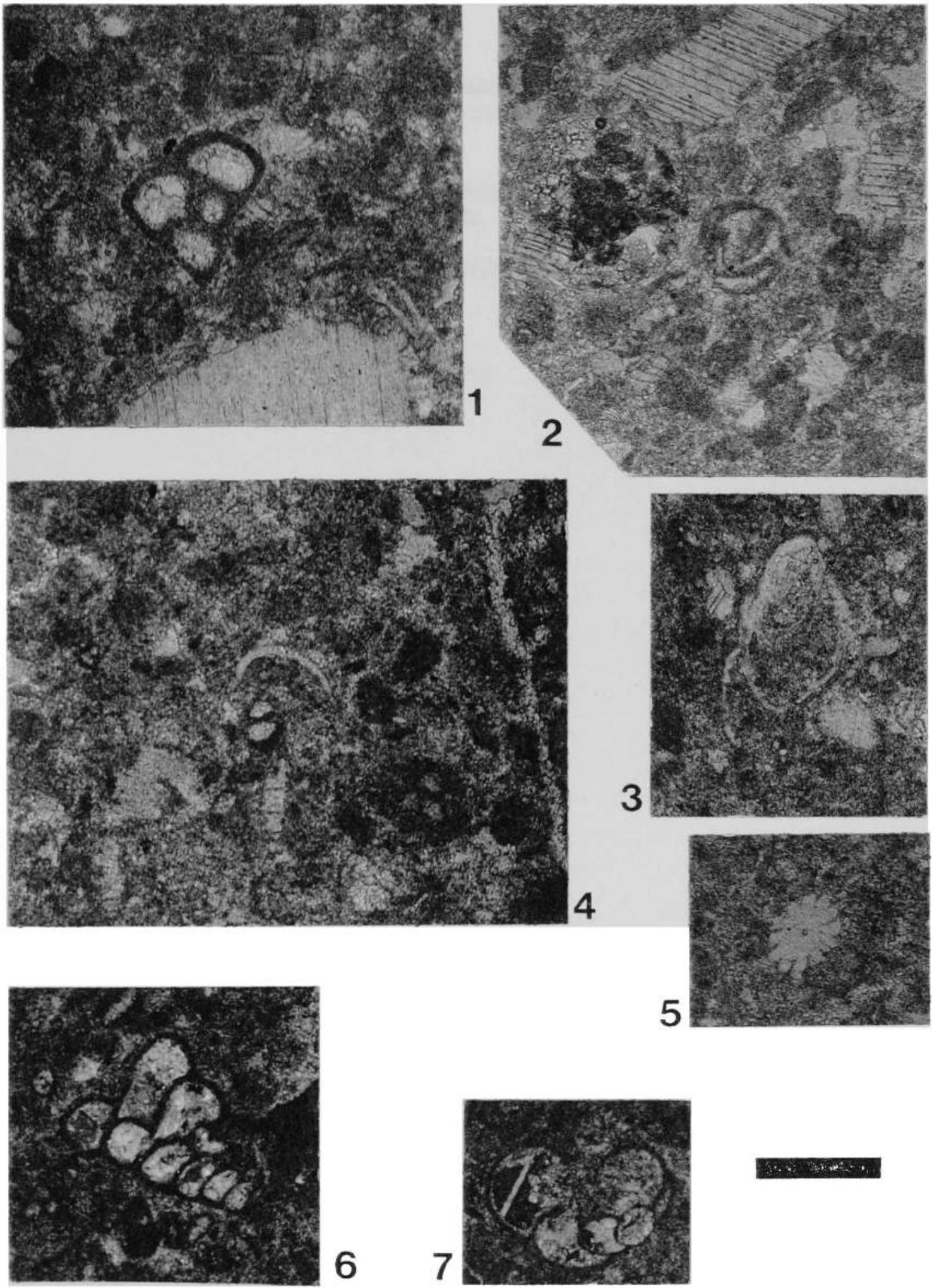
PLATE 15. Cupido Formation, Presa Francisco Zarco (Subunit PFZ-G)

Figure 1. Rudist fragment. Sample PFZ-58a.

Figure 2. Biocalcarenite with benthonic foraminifera of the miliolid group, pellets and echinoid fragments. The intraclast is made of a mollusk fragment, embraced by a micritic envelope. Sample PFZ-58c.

Figure 3. Biocalcarenite with benthonic foraminifera of the miliolid group, pellets, echinoid fragments. Sample PFZ-58c.

Figure 4. Calcareous sponge. Irregular canals filled with sparry calcite. Sample PFZ-58c.

Scale $\mathrm{Bar}=1000$ microns for all figures. 


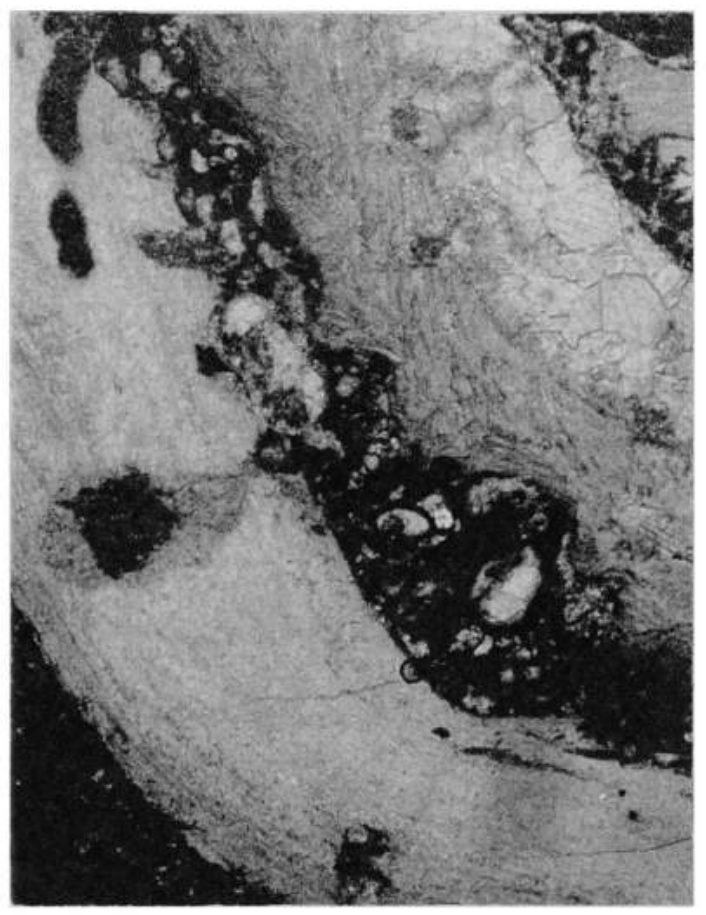

1

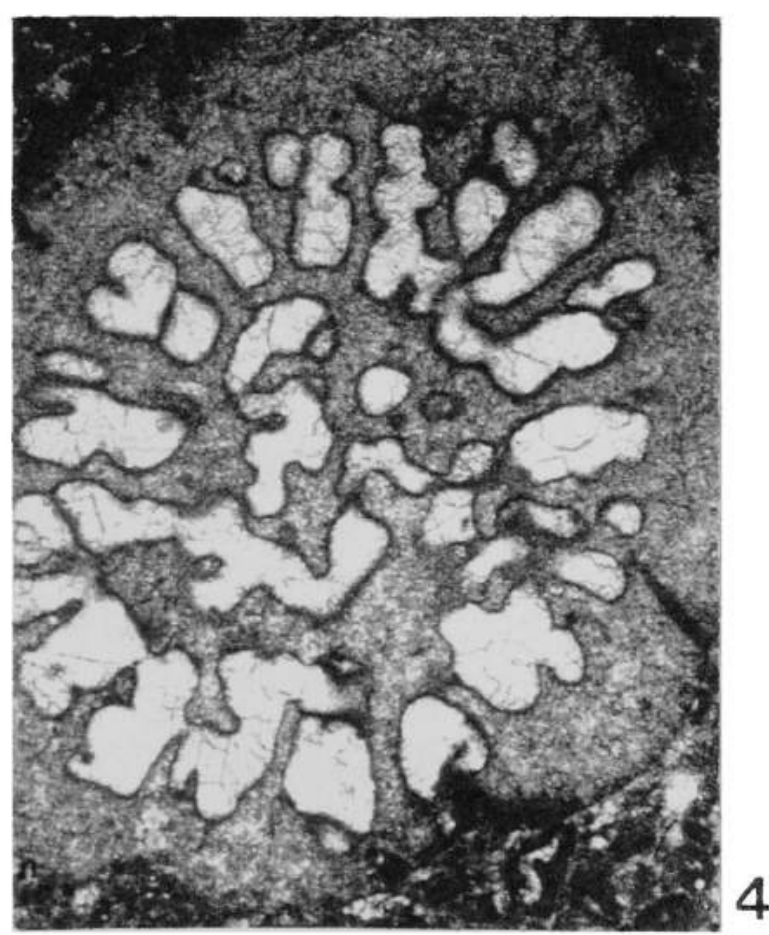

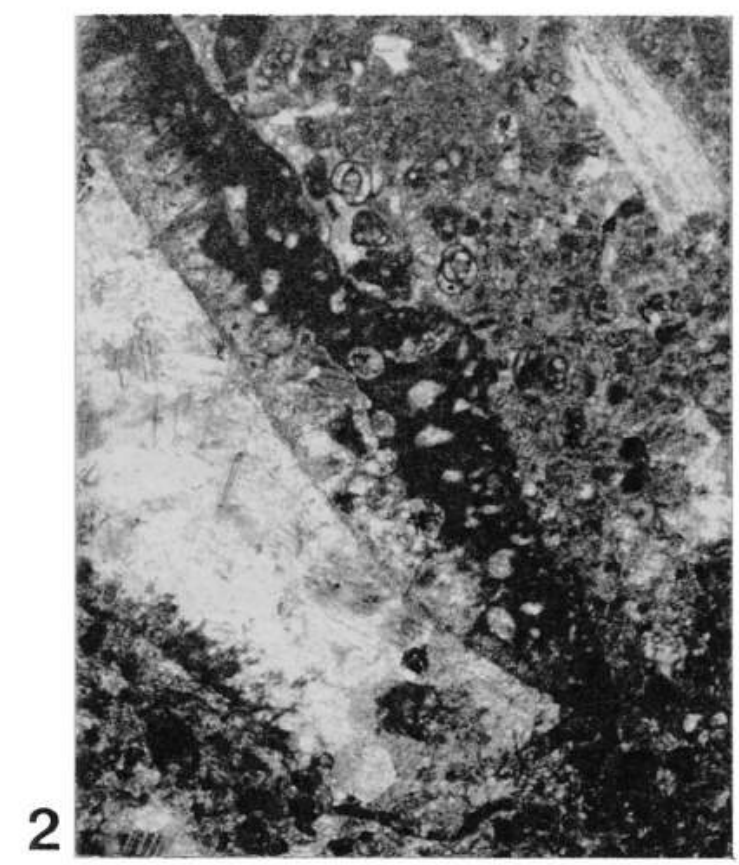

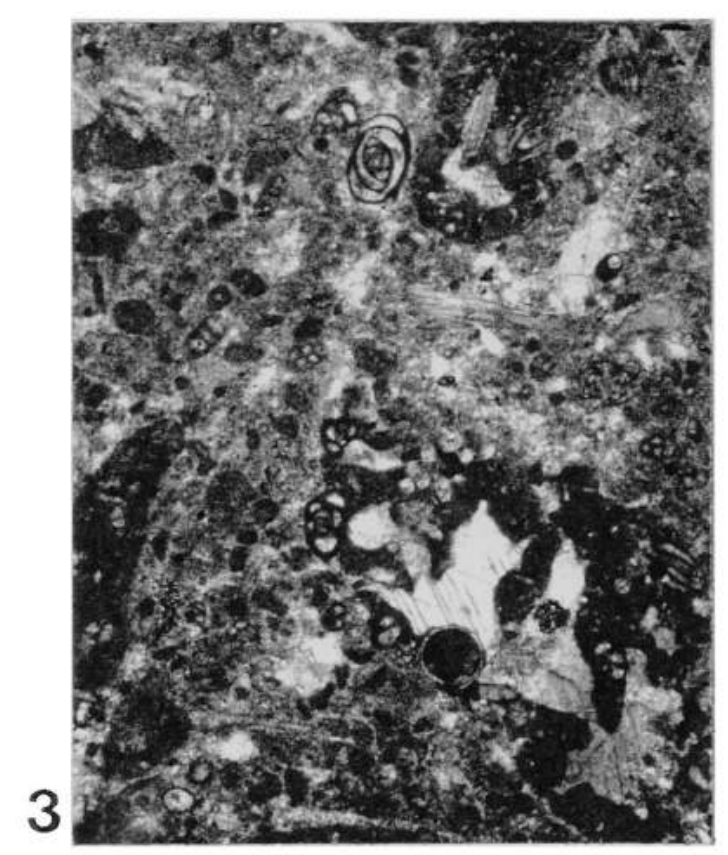

4 
PLATE 16. Cupido Formation, Presa Francisco Zarco (Subunit PFZ-G, Sample PFZ-58c)

Figure 1. Pelloidal biocalcarenite with benthonic foraminifera (Camerinid?). Sample PFZ-58c.

Figure 2. Recrystallized ostracod. PFZ-58c.

Figure 3. Pelloidal biocalcarenite with mollusk fragment. Sample PFZ-58c.

Figure 4. Pelloidal biocalcarenite with benthonic foraminifera of the miliolid group and intraclasts. Matrix in this area of the sample consists of sparry calcite cement. Sample PFZ-58c.

Figure 5. Miliolid benthonic foraminifera. Note the blocky crystals of the sparry calcite cement. Sample PFZ-58c.

Figure 6. Miliolid benthonic foraminifera. Sample PFZ-58c.

Scale $\mathrm{Bar}=400$ microns for all figures. 

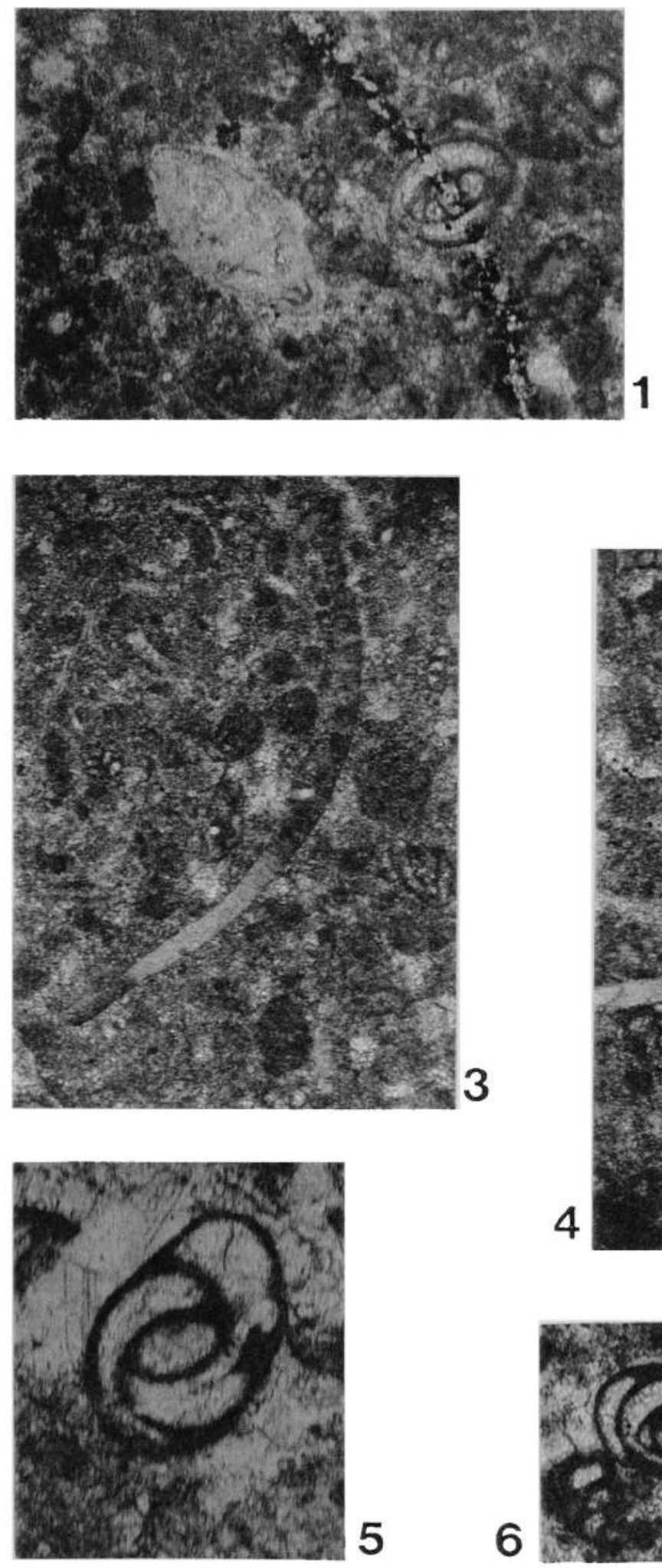
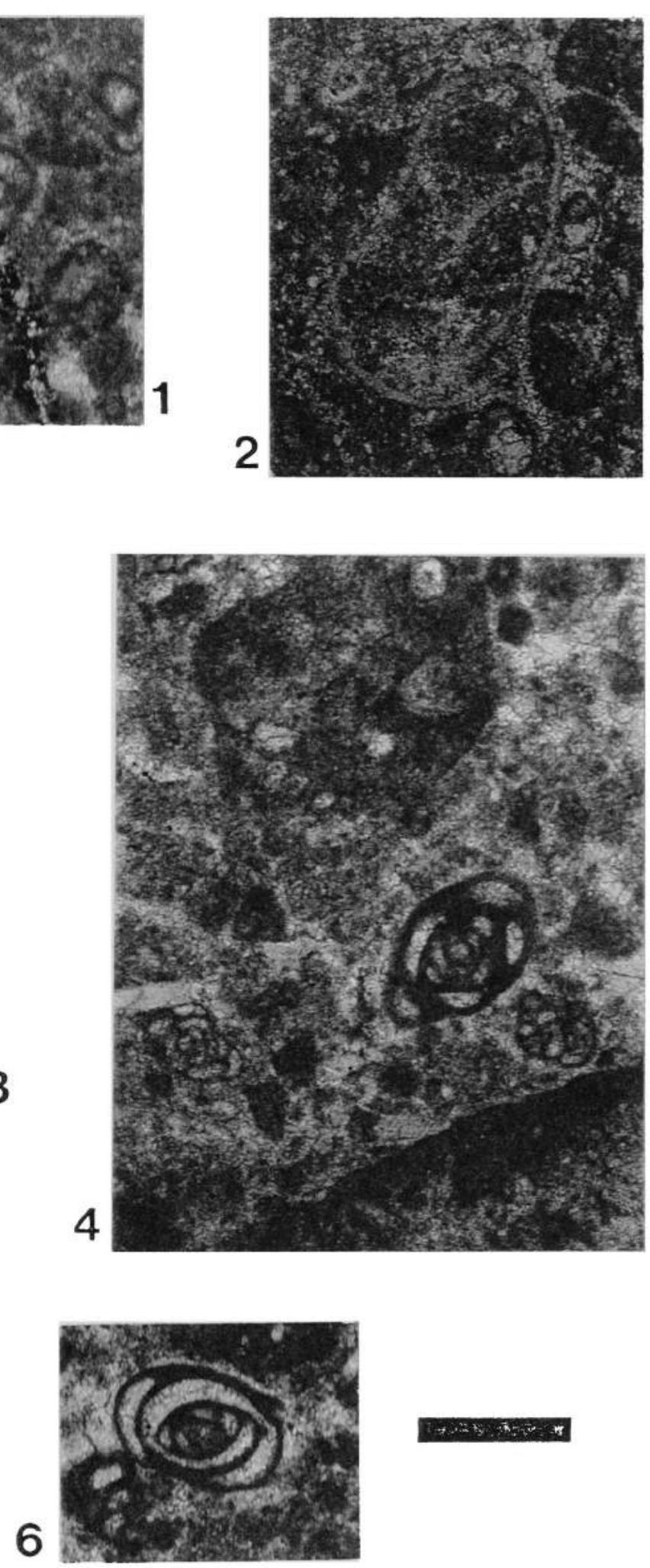

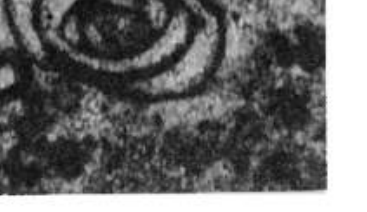


PLATE 17. Cupido Formation, Presa Francisco Zarco (Subunit PFZ*G)

Figure 1. Echinoid spine. Sample PFZ-59a.

Figure 2. Benthonic foraminifera. Sample PFZ-59a.

Figure 3. Biserial benthonic foraminifera. Sample PFZ-59b.

Figure 4. Benthonic foraminifera. Sample PFZ-59b.

Figure 5. Quiqueloculinid miliolid foraminifera. Sample PFZ-59b.

Figure 6. Planispiral benthonic foraminifera. Sample PFZ-59b.

Figure 7. Trochospiral foraminifera. Sample PFZ-59b.

Figure 8. Benthonic foraminifera. Sample PFZ-59b.

Figure 9. Peloids. Sample PFZ-59c.

Figure 10. Mollusk fragment. Sample PFZ 59 c.

Scale $\mathrm{Bar}=400$ microns for all figures. 

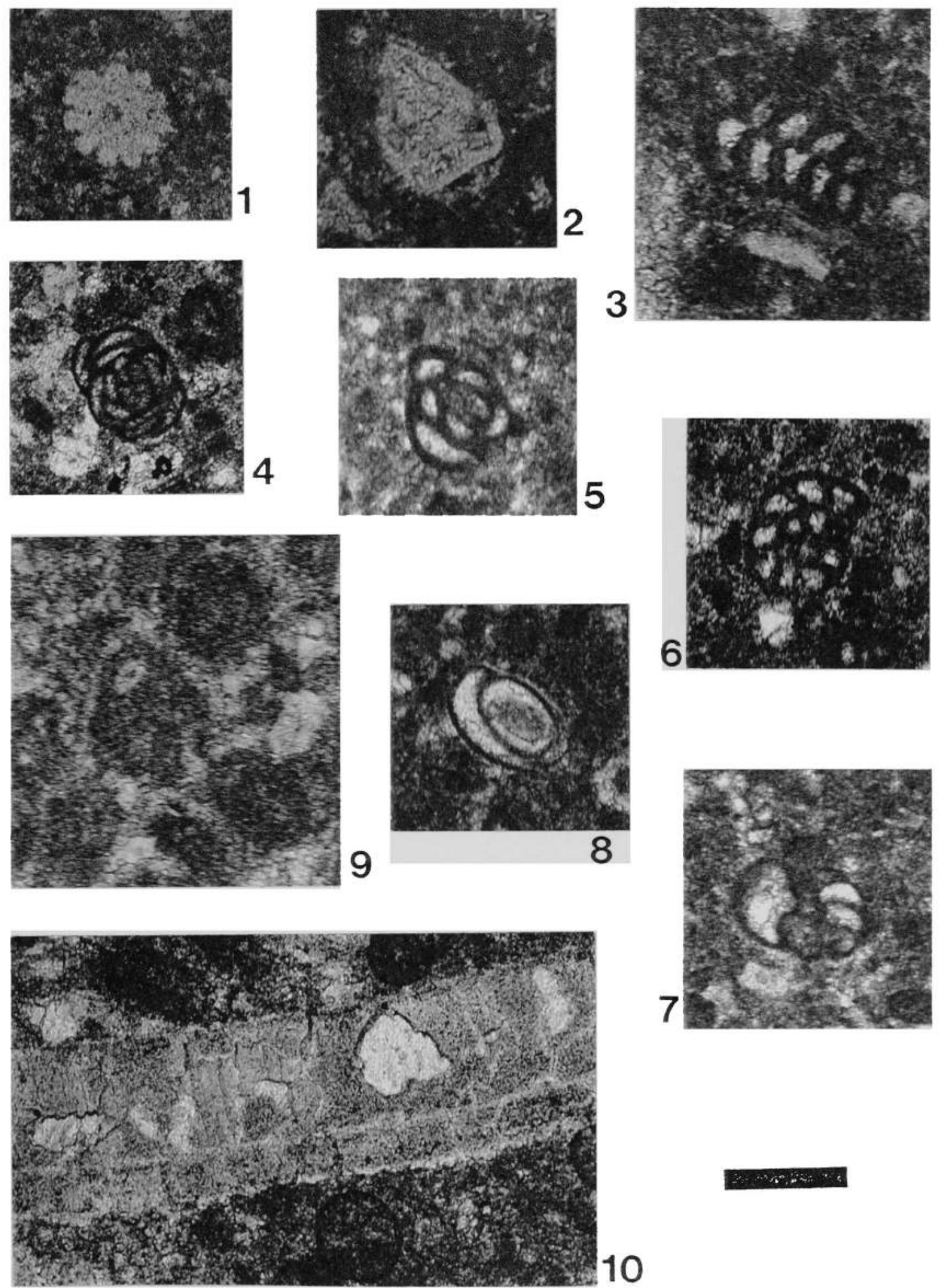
PLATE 18. Cupido Formation, Presa Francisco Zarco (Subunit PFZ*G, sample PFZ-59d)

Figure 1. Biocalcilutite with benthonic foraminifera and mollusk fragments. Sample PFZ-59d. Scale Bar $=800$ microns.

Figure 2. Biocalcilutite rich in miliolid benthonic foraminifera, intraclasts, and peloids. Sample PFZ-59d. Scale Bar $=800$ microns.

Figure 3. Rudist fragment. Sample PFZ-59d. Scale Bar $=800$ microns.

Figure 4. Miliolid benthonic foraminifera, Sample PFZ-59d. Scale Bar $=400$ microns.

Figure 5. Recrystallized mollusk fragment. Sample PFZ-59d. Scale Bar $=400$ microns. 

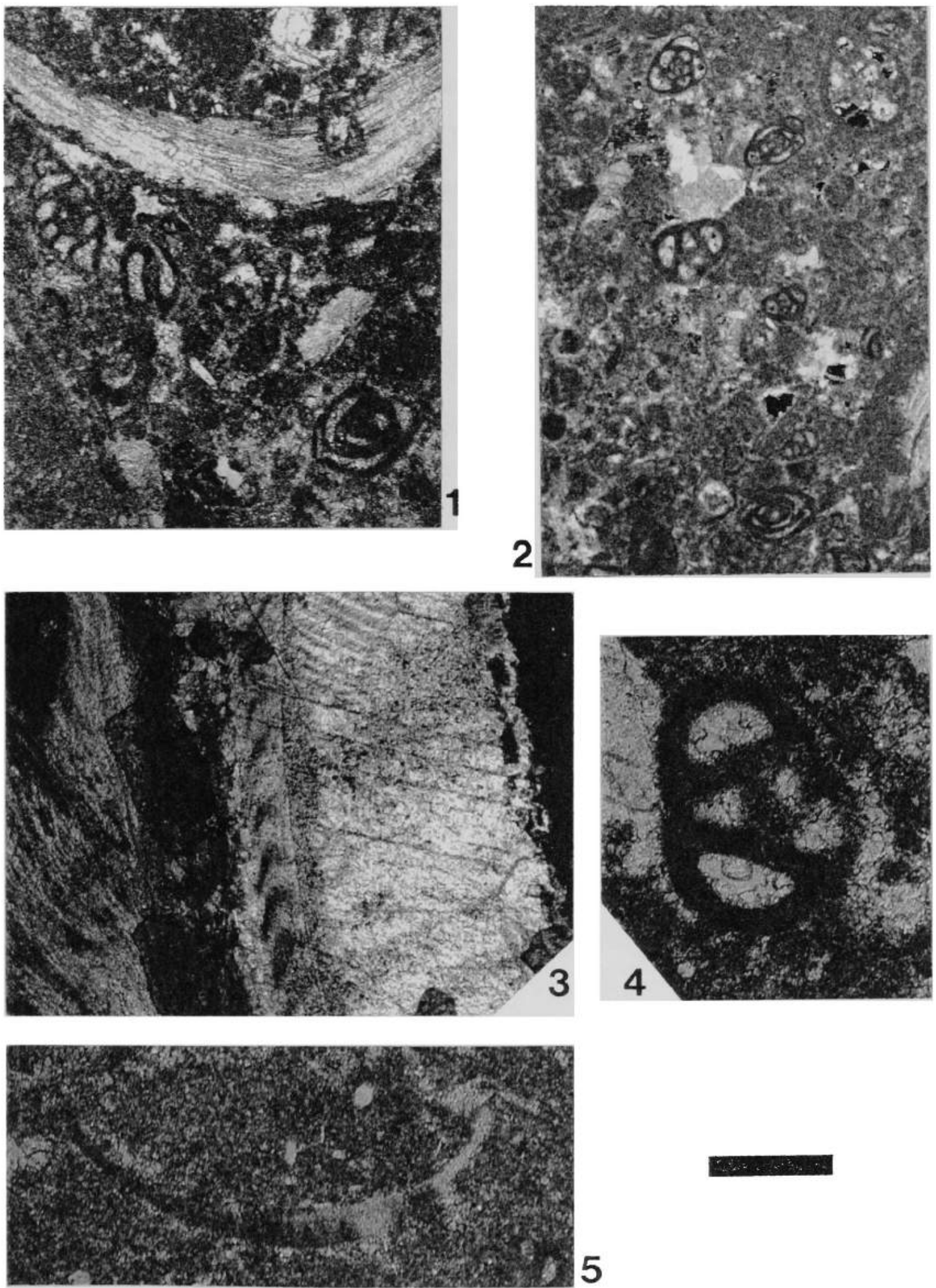


\section{PLATE 19. Cupido Formation, Presa Francisco Zarco (Subunit PFZ-G, sample PFZ 59d)}

Figure 1. Benthonic foraminifera of the miliolid group. Sample PFZ-59d.

Figure 2. Triloculinid miliolid foraminifera. Sample PFZ-59d.

Figure 3. Biosparite with miliolid foraminifera. Sample PFZ-59d.

Figure 4. Miliolid foraminifera. Sample PFZ-59d.

Figure 5. Miliolid foraminifera. Sample PFZ-59d.

Figure 6. Quinqueloculinid miliolid foraminifera and peloids. Note blocky crystals of sparry calcite cement. Sample PFZ-59d.

Figure 7. Quiqueloculinid miliolid foraminifera. Sample PFZ-59d.

Figure 8. Triloculinid miliolid foraminifera. Sample PFZ-59d.

Scale Bar $=400$ microns for all figures. 
PLATE 19
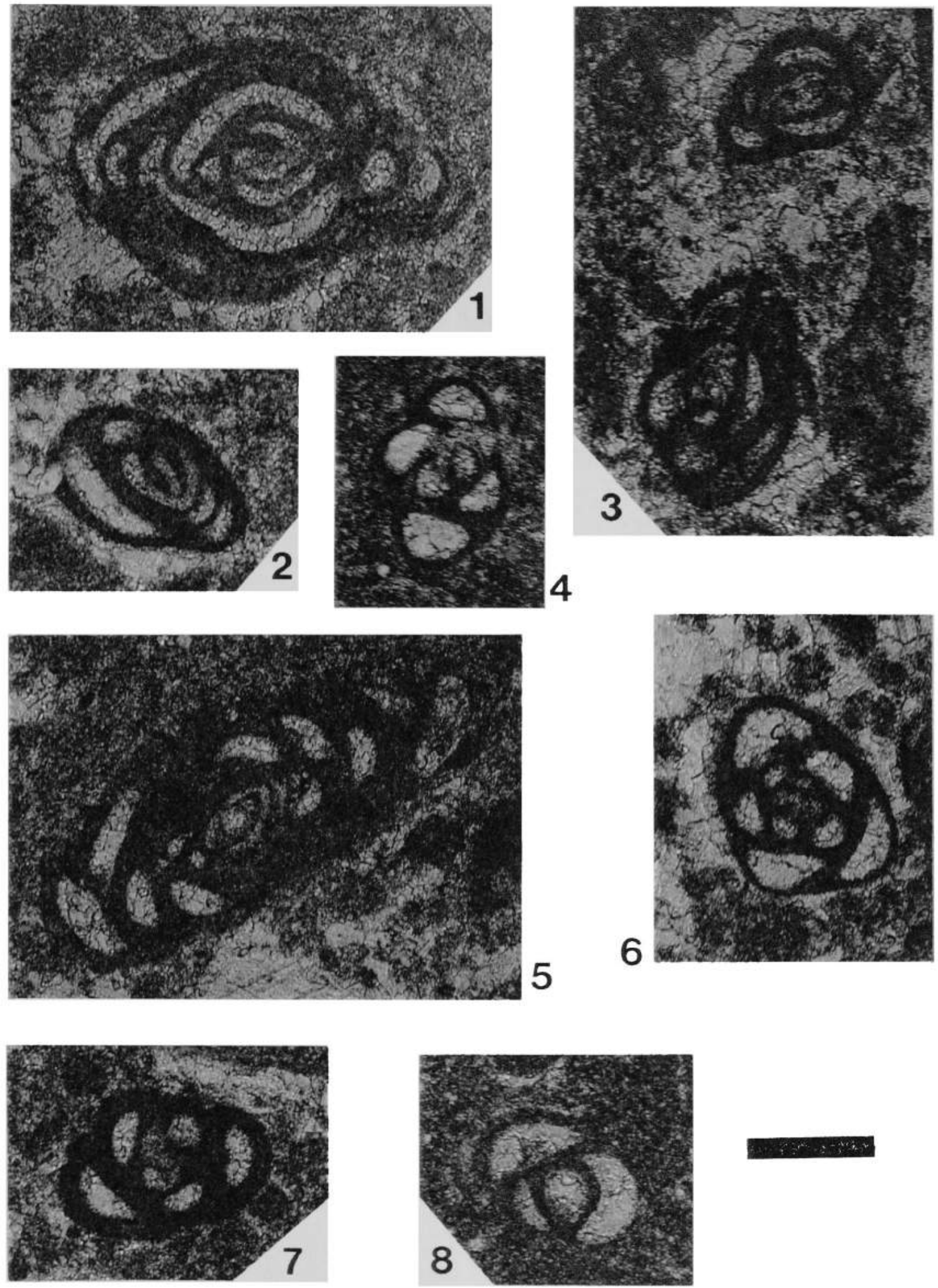


\section{PLATE 20. Cupido Formation, Presa Francisco Zarco (Subunit PFZ-G, sample PFZ-59e)}

Figure 1. Biocalcilutite rich in benthonic foraminifera of the miliolid group and intraclasts. Sample PFZ-59e. Scale Bar $=800$ microns.

Figure 2. Benthonic foraminifera. Sample PFZ-59e. Scale Bar $=400$ microns.

Figure 3. Miliolid benthonic foraminifera. Sample PFZ-59e. Scale Bar $=400$ microns .

Figure 4. Benthonic foraminifera. Sample PFZ-59e. Scale Bar $=400$ microns.

Figure 5. Triloculinid miliolid foraminifera. Sample PFZ-59e. Scale Bar $=400$ microns.

Figure 6. Benthonic foraminifera. Sample PFZ $-59 \mathrm{e}$. Scale Bar $=400$ microns. 

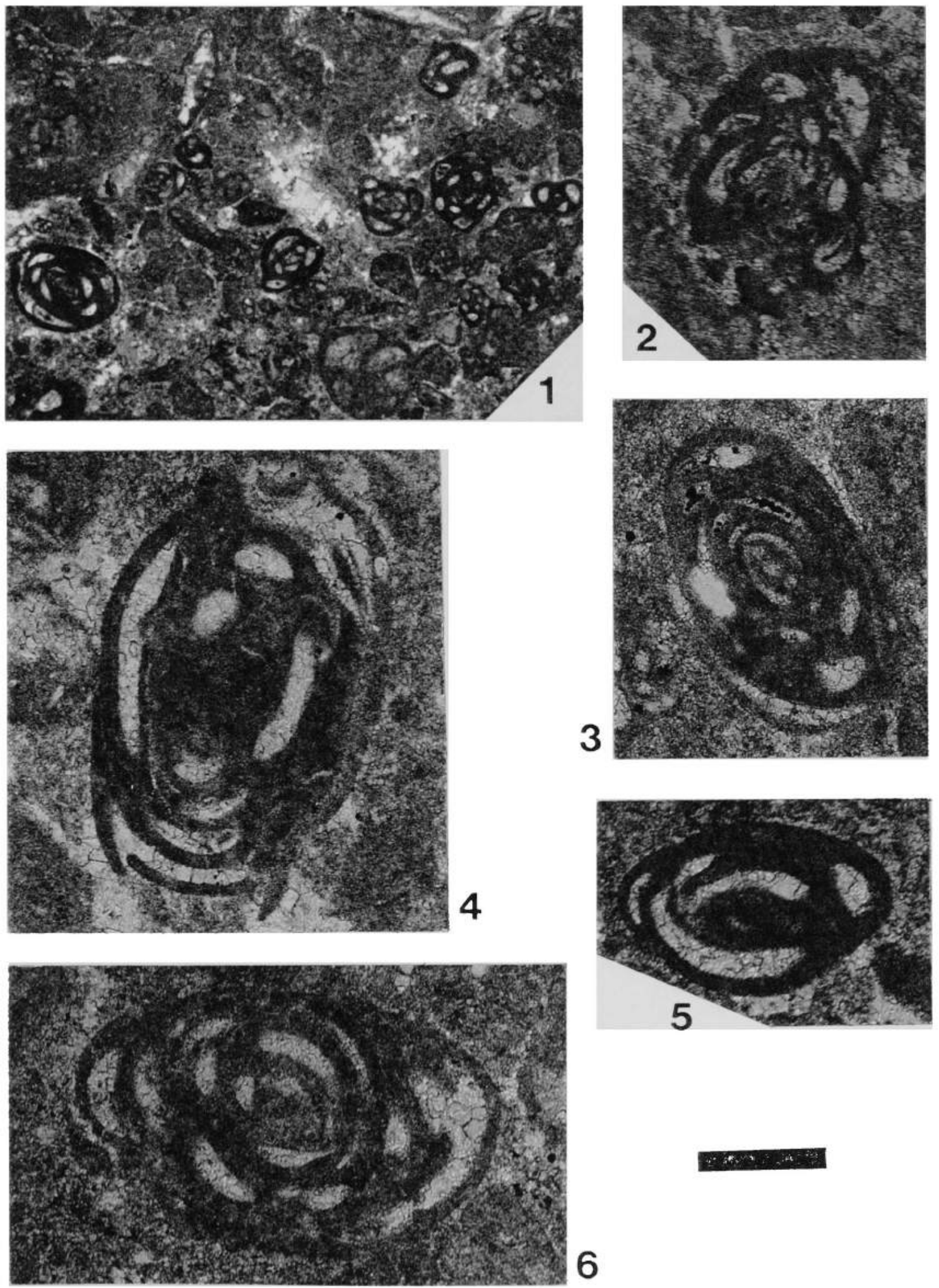


\section{PLATE 21. Cupido Formation, Presa Francisco Zarco (Subunit PFZ-G, sample PFZ 59e)}

Figure 1. Biocalcilutite with benthonic foraminifera, mollusk and echinoid fragments. Sample PFZ-59e.

Figure 2. Quinqueloculinid and triloculinid miliolid benthonic foraminifera. Sample PFZ-59e.

Figure 3. Biocalcilutite with benthonic foraminifera and crinoid fragments. Sample PFZ-59e.

Figure 4. Triloculinid miliolid benthonic foraminifera. Sample PFZ-59e.

Figure 5. Miliolid benthonic foraminifera. Sample PFZ-59e.

Figure 6. Planispiral benthonic foraminifera. Sample PFZ-59e.

Scale $\mathrm{Bar}=400$ microns for all figures. 

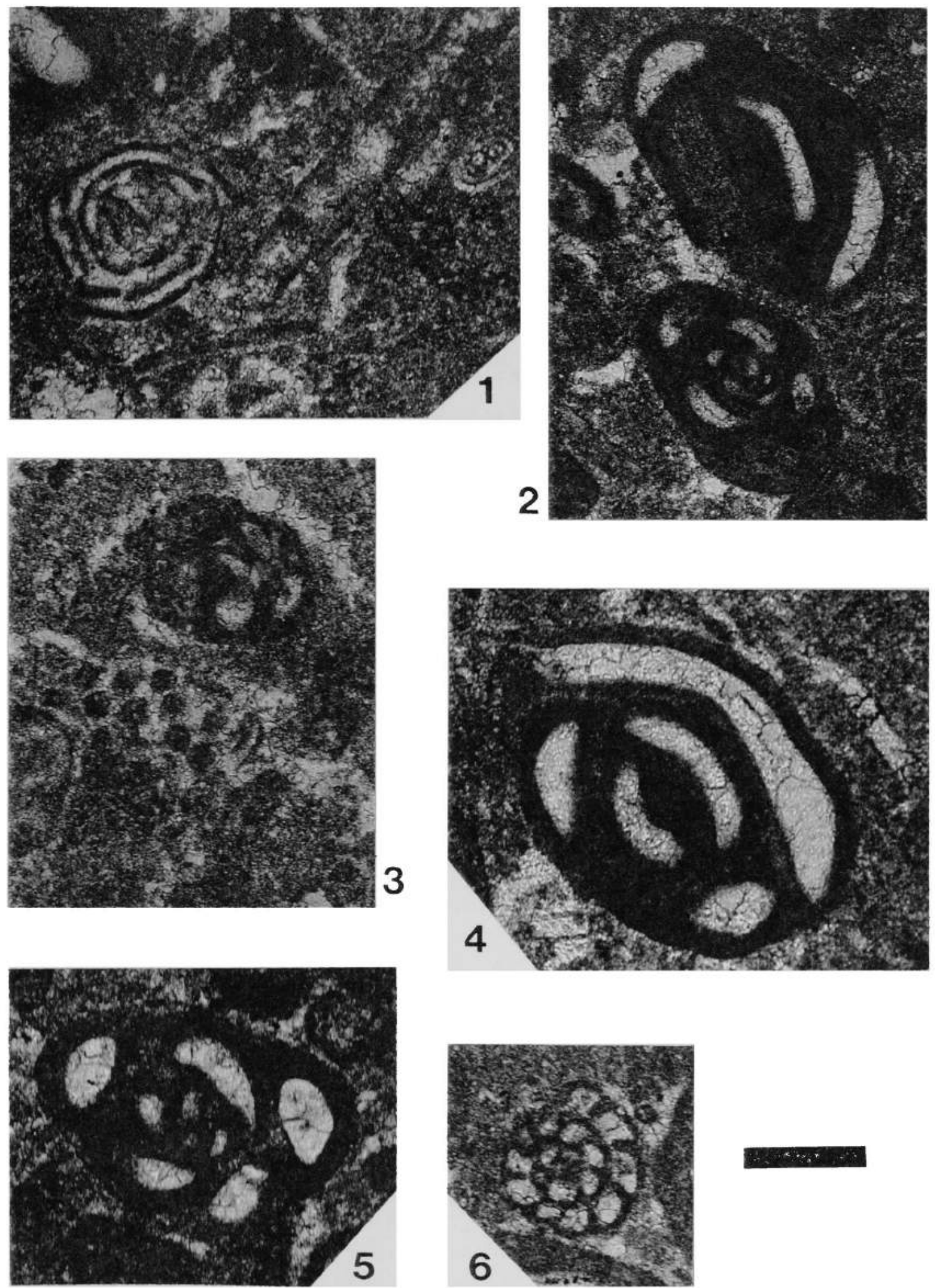
PLATE 22. Cupido Formation, Presa Francisco Zarco (Subunit PFZ-G, sample PFZ-59e)

Figure 1. Biocalcilutite with benthonic foraminifera, and intraclasts. Sample PFZ-59e.

Figure 2. Miliolid benthonic foraminifera. Note the blocky crystals of the sparry calcite cement. Sample PFZ-59e.

Figure 3. Benthonic foraminifera. Sample PFZ-59e.

Figure 4. Recrystallized sponge fragment?. Sample PFZ-59e.

Figure 5. Benthonic foraminifera. Sample PFZ-59e.

Figure 6. Benthonic foraminifera. Sample PFZ-59e.

Figure 7. Biserial benthonic foraminifera. Sample PFZ-59e.

Scale $B a r=400$ microns for all figures. 

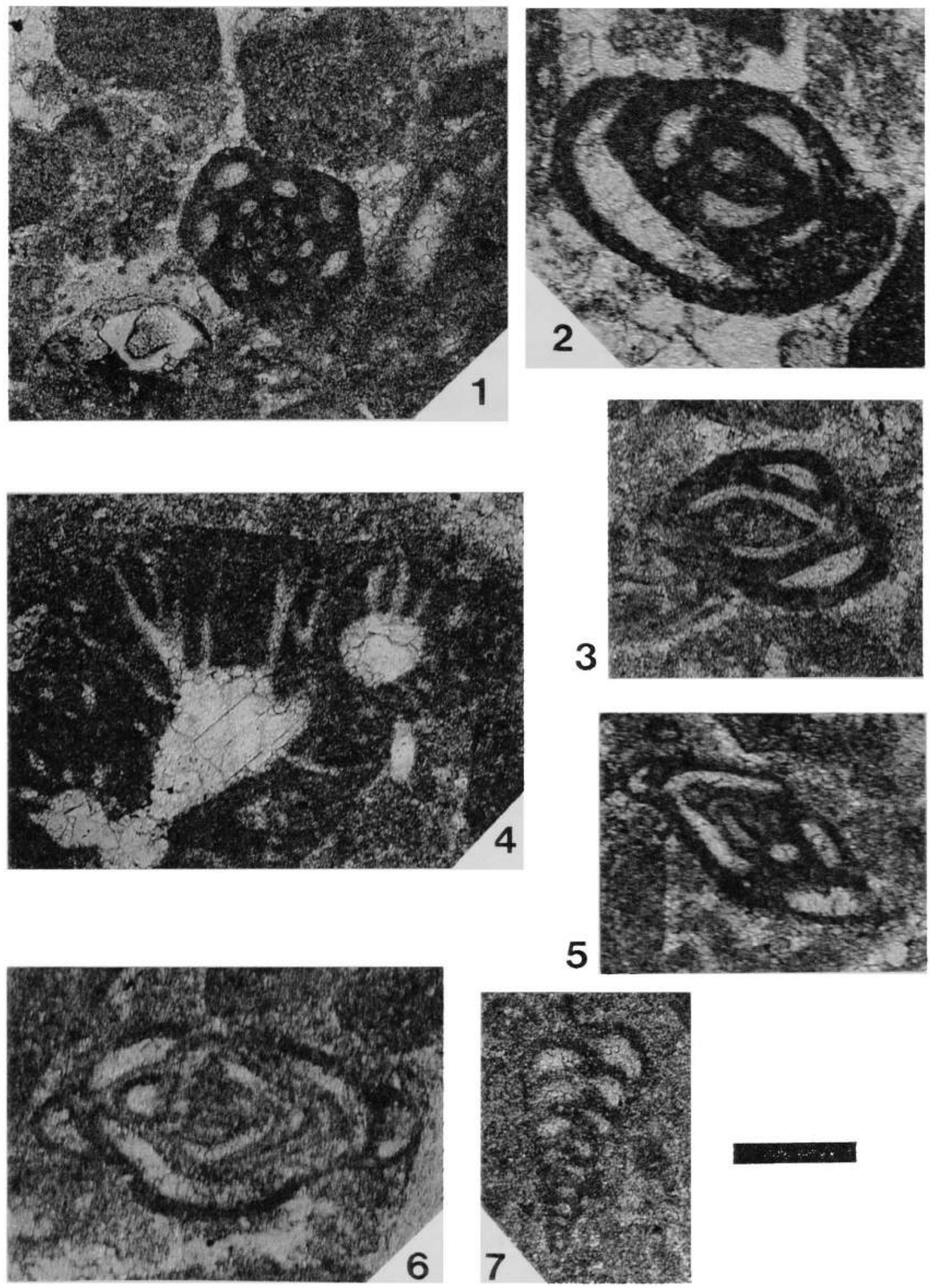


\section{PLATE 23. La Peña Formation, Presa Francisco Zarco (Subunit PFZ-H)}

Figure 1. Biocalcilutite with benthonic foraminifera of the orbitolinid(?) and miliolid groups. Sample PFZ-61a. Scale Bar $=1000$ microns.

Figure 2. Biocalcilutite with benthonic foraminifera. Some areas of the matrix display microsparitic calcite cement. Sample PFZ-61a. Scale Bar $=400$ microns.

Figure 3. Miliolid benthonic foraminifera. Sample PFZ-61a. Scale Bar $=400$ microns.

Figure 4. Triloculinid miliolid foraminifera. Sample PFZ-6la. Scale Bar $=400$ microns .

Figure 5. Benthonic foraminifera. Sample PFZ-61a. Scale Bar $=400$ microns.

Figure 6. Benthonic foraminifera. Sample PFZ-61b. Scale Bar $=400$ microns.

Figure 7. Recrystallized orbitolinid benthonic foraminifera. Sample PFZ-61b. Scale Bar $=400$ microns.

Figure 8. Benthonic foraminifera. Sample PFZ-61b. Scale Bar $=400$ microns.

Figure 9. Planktonic(?) foraminifera. Sample PFZ 61b. Scale Bar $=400$ microns. 
PLATE 23
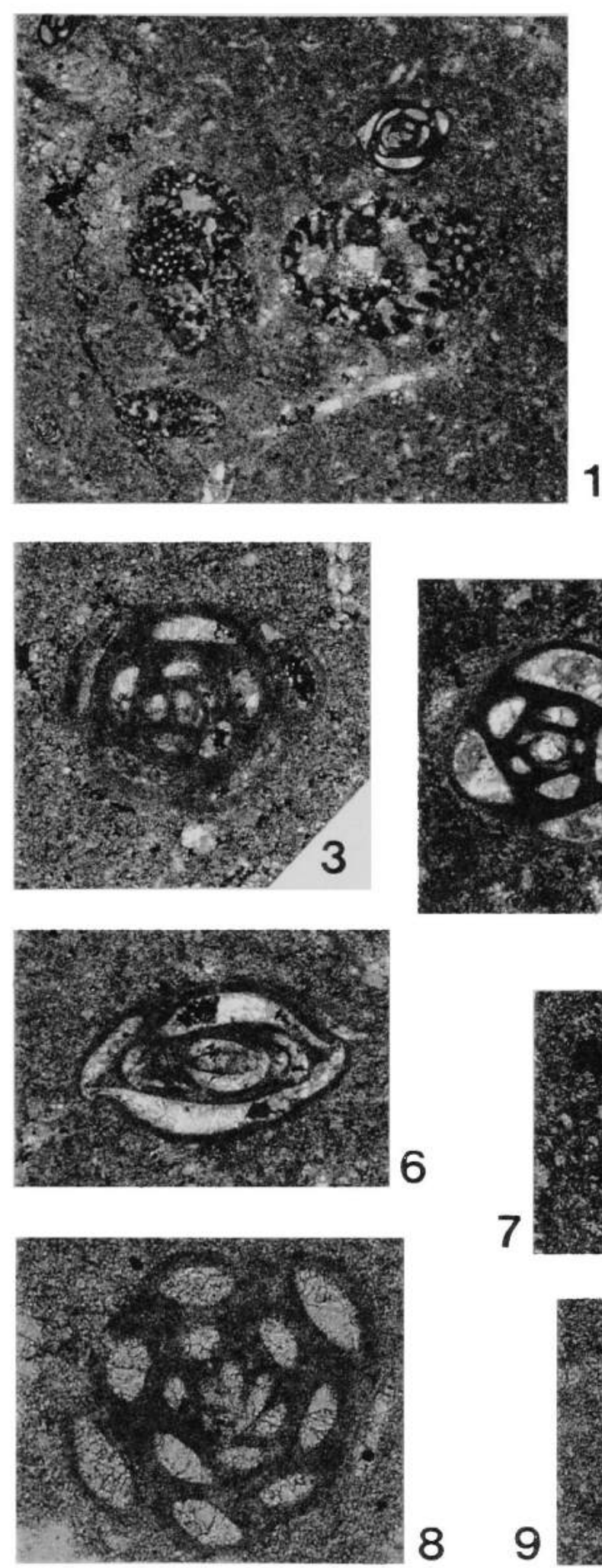
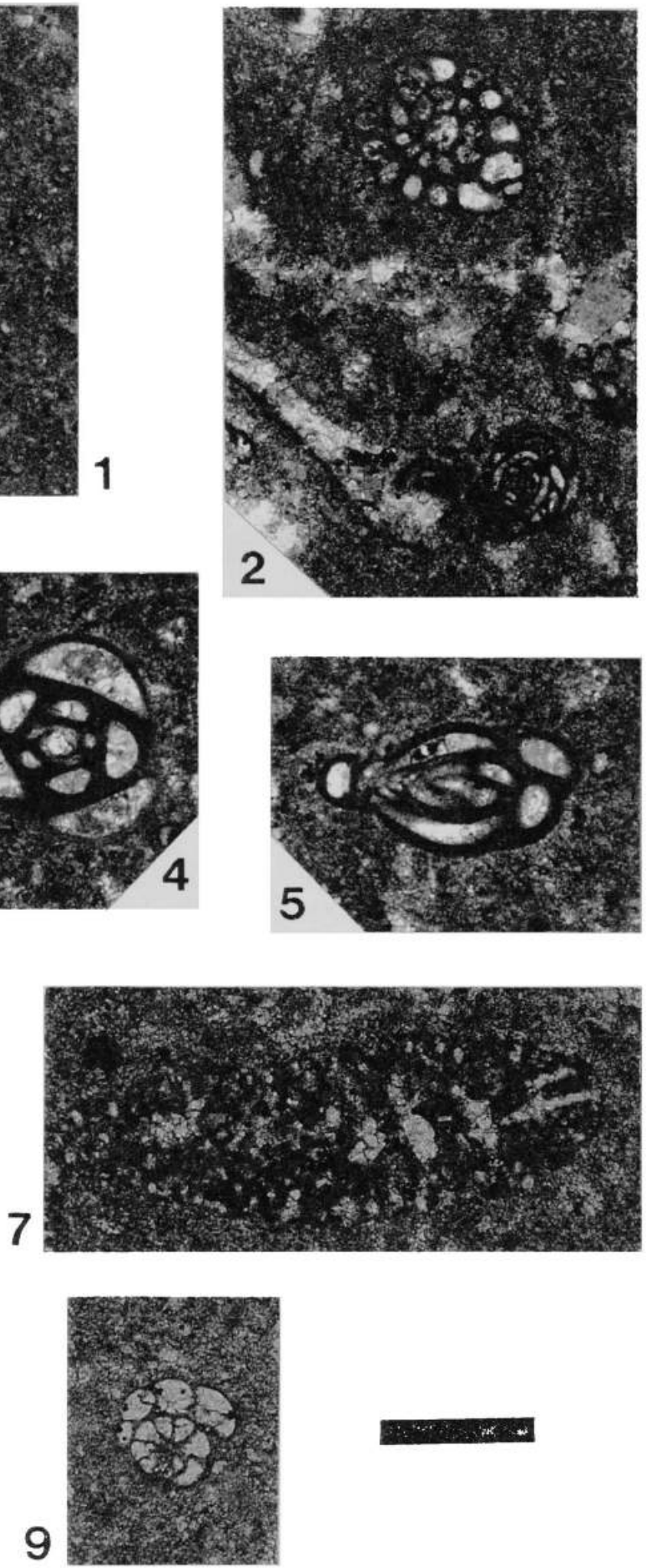
PLATE 24. La Peña Formation, Presa Francisco Zarco (Subunit PFZ-H)

Figure 1. Benthonic foraminifera. Sample PFZ-6Ib.

Figure 2. Benthonic foraminifera. Sample PFZ-61b.

Figure 3. Benthonic foraminifera. Sample PFZ-61b.

Figure 4. Planktonic(?) foraminifera. Sample PFZ-61b.

Figure 5. Quinqueloculinid miliolid benthonic foraminifera. Sample PFZ-6Ib.

Figure 6. Planktonic (?) foraminifera. Sample PFZ-61b.

Figure 7. Benthonic foraminifera. Sample PFZ-61b.

Figure 8. Benthonic foraminifera. Sample PFZ-61b.

Figure 9. Miliolid benthonic foraminifera. Sample PFZ-61b.

Figure 10. Biocalcilutite with benthonic foraminifera. Sample PFZ-61c.

Figure 11. Benthonic foraminifera. Sample PFZ-61c.

Scale $\mathrm{Bar}=400$ microns for all figures. 

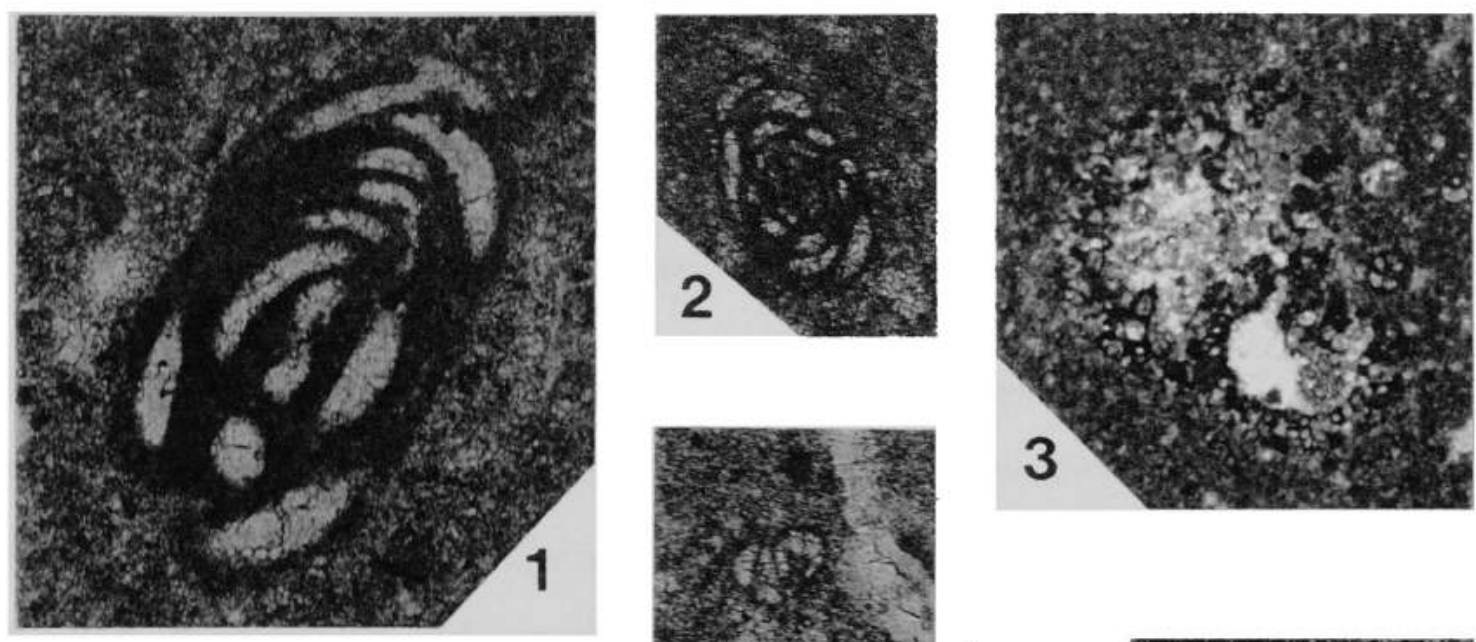

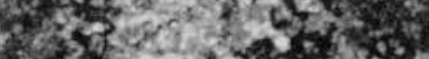
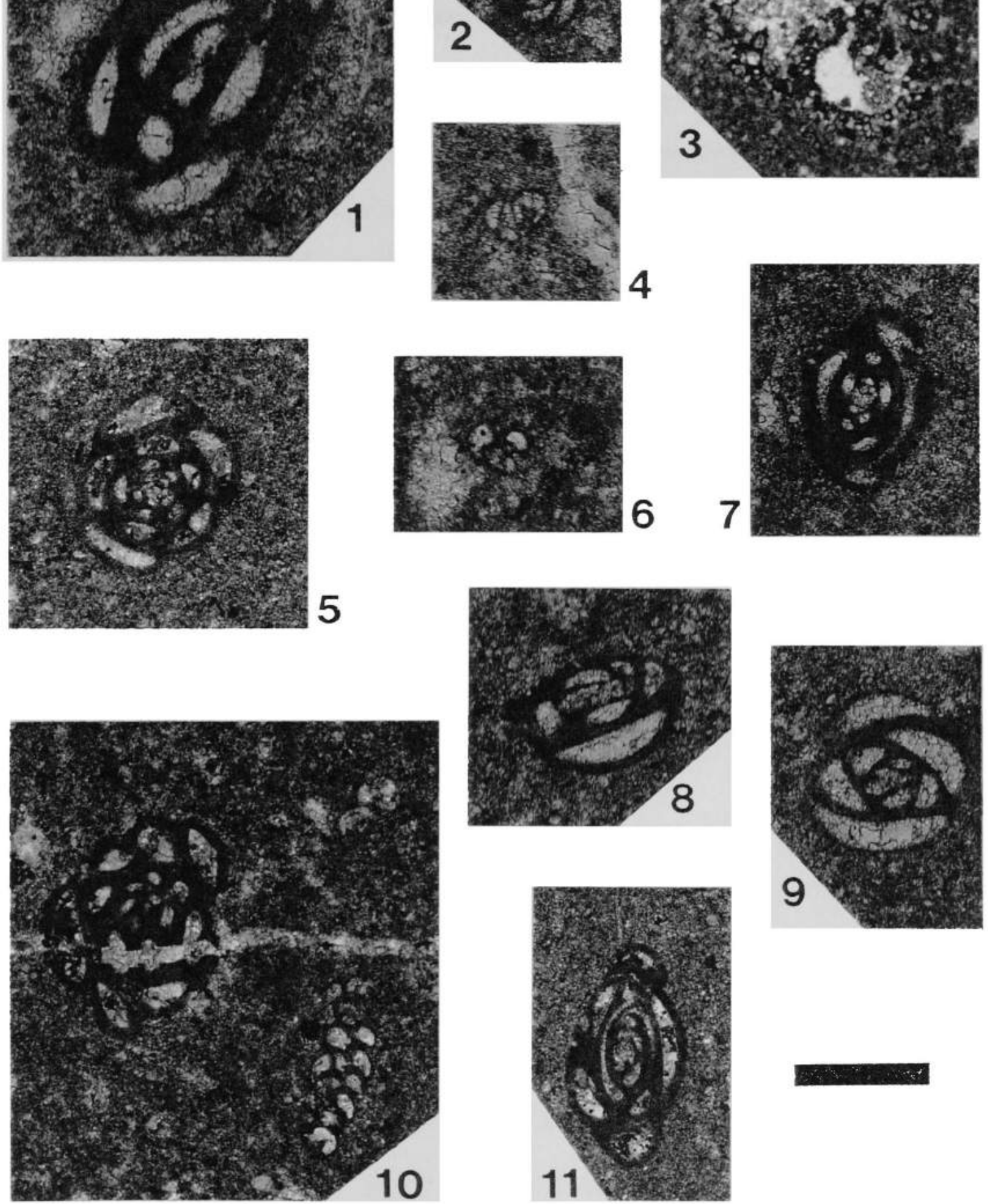


\section{PLATE 25. La Peña Formation, Presa Francisco Zarco (Subunit PFZ-I)}

Figure 1. Biocalcilutite with planktonic foraminifera and mollusk fragments. Matrix mainly composed of micritic calcite and some patches of microspar. Sample PFZ-65. Scale Bar $=400$ microns.

Figure 2. Biocalcilutite with sparse planktonic foraminifera and mollusk fragments. Note microveins filled with calcite. Sample PFZ-65.

Scale Bar $=400$ microns.

Figure 3. Planktonic foraminifera. Sample PFZ-79. Scale Bar $=400$ microns.

Figure 4. Planktonic foraminifera. Sample PFZ-79. Scale Bar $=400$ microns.

Figure 5. Planktonic foraminifera. Sample PFZ-79. Scale Bar $=400$ microns.

Figure 6. Planktonic foraminifera. Sample PFZ-79. Scale Bar $=200$ microns.

Figure 7. Biocalcilutite with a recrystallized mollusk fragment. Sample PFZ 81 . Scale Bar $=400$ microns.

Figure 8. Echinoid fragment. Sample PFZ-89. Scale Bar $=400$ microns.

Figure 9. Biocalcilutite with recrystallized mollusk and echinoid fragments. Sample PFZ -89 . Scale Bar $=400$ microns. 
PLATE 25
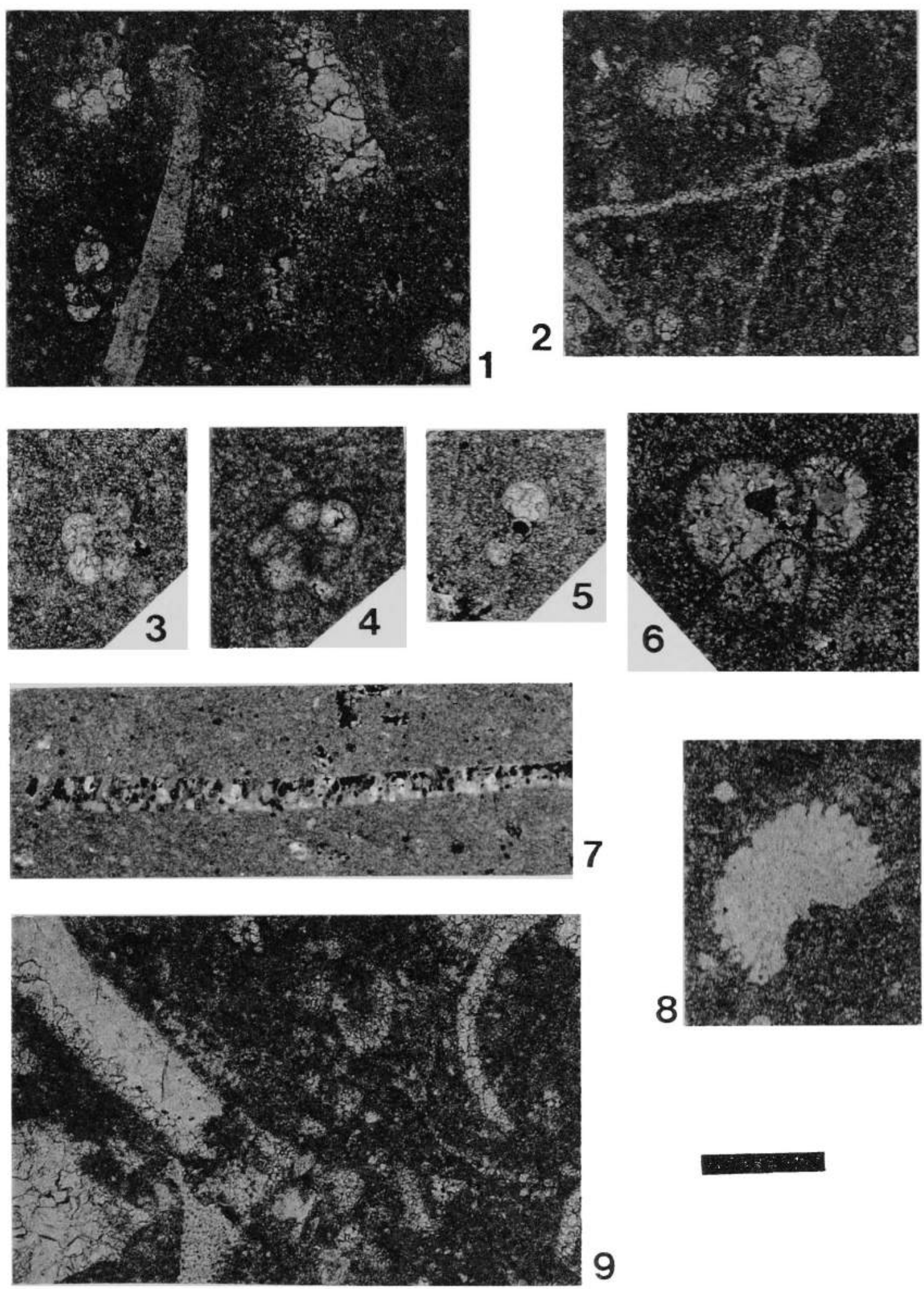
PLATE 26. La Peña Formation, Presa Francisco Zarco (Subunit PFZ-1)

Figure 1. Biocalcilutite with planktonic foraminifera, mollusk and echinoid fragments, and peloids. Matrix mainly composed of micritic calcite and some patches of microspar. Sample PFZ-104.

Figure 2. Recrystallized mollusk fragment. Sample PFZ-104.

Figure 3. Intraclast. Sample PFZ-108.

Figure 4. Biocalcilutite with echinoid spines. Sample PFZ-110.

Figure 5. Biocalcilutite with foraminifera: biserial, and trochospiral planktonic. Sample PFZ-113a.

Figure 6. Biocalcilutite with planktonic foraminifera and terrigenous materials. Sample PFZ-117.

Figure 7. Biocalcilutite with planktonic foraminifera and terrigenous materials. Sample PFZ-117.

Scale $\mathrm{Bar}=400$ microns for all figures. 

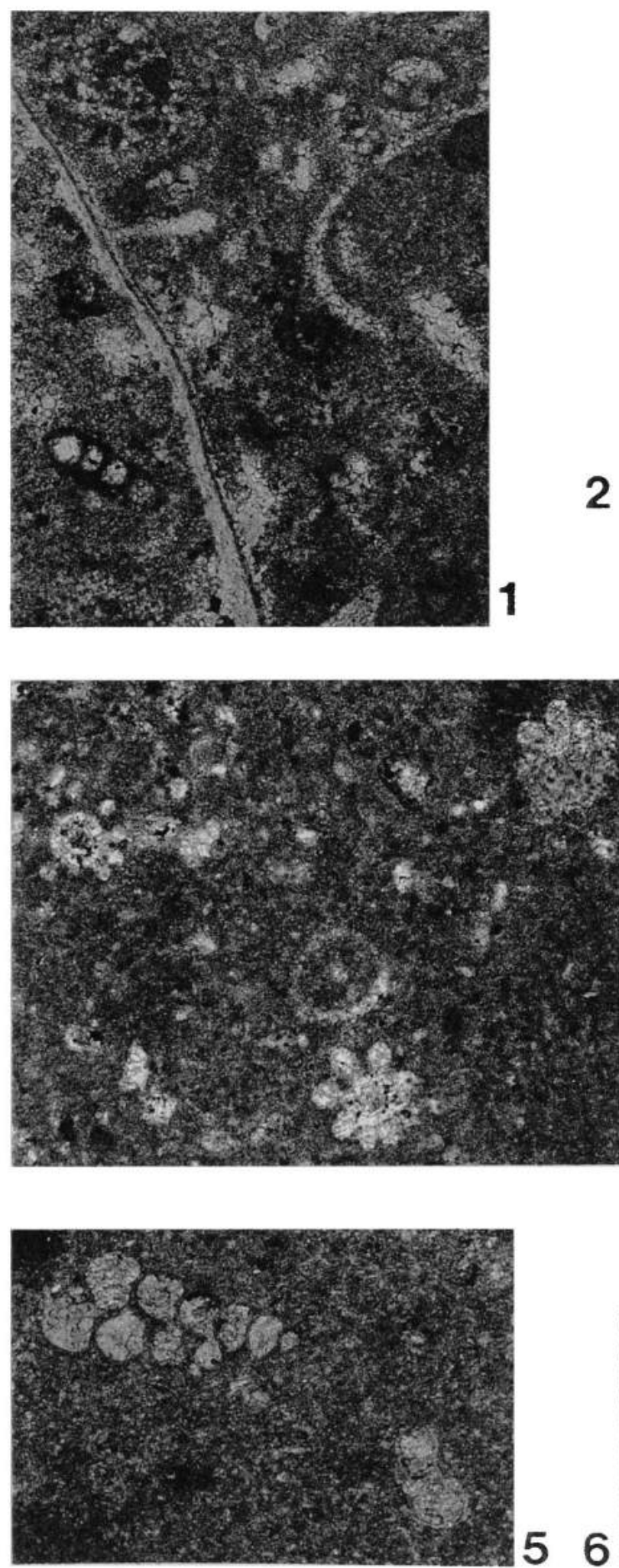
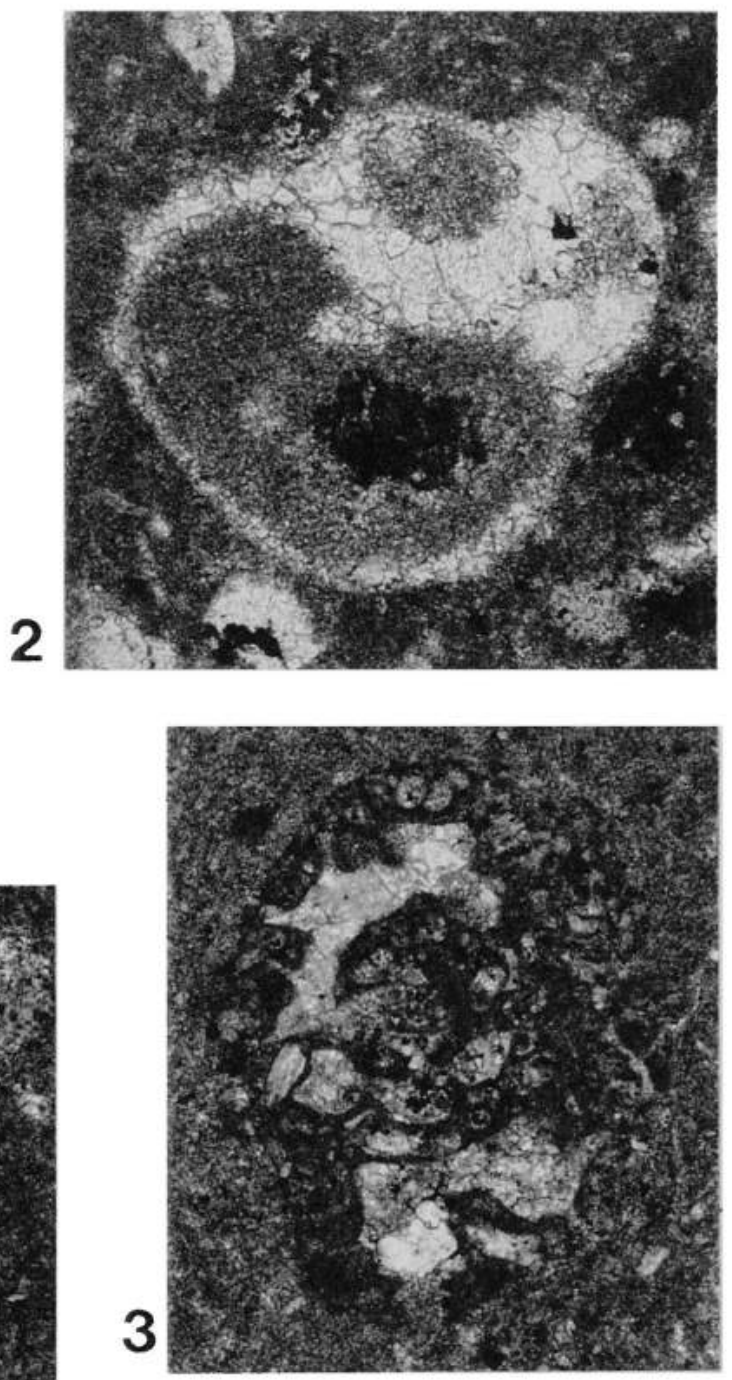

4
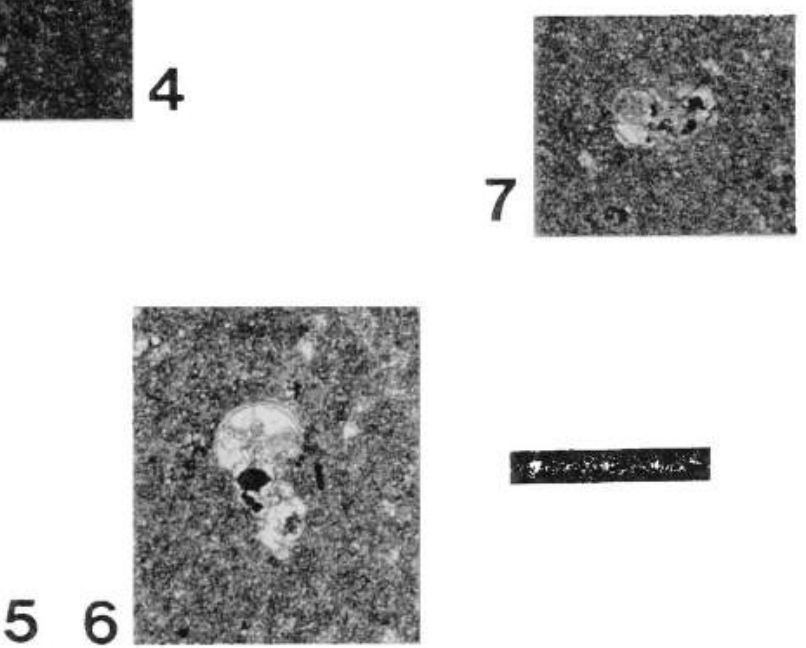


\section{PLATE 27. La Peña Formation, Presa Francisco Zarco (Subunit PFZ-1)}

Figure 1. Planktonic foraminifera. Sample PFZ-122.

Figure 2. Trochospiral planktonic foraminifera (Globuligerina ?) Sample PFZ-124a.

Figure 3. Undetermined. Sample PFZ-124a.

Figure 4. Benthonic foraminifera. Sample PFZ-124a.

Figure 5. Biocalcilutite with planktonic foraminifera. Sample PFZ-125.

Figure 6. Trochospiral planktonic foraminifera (Hedbergella). Sample PFZ 125.

Figure 7. Ostracod. Sample PFZ-129.

Figure 8. Biocalcilutite with planktonic foraminifera and terrigenous materials. Matrix composed of microsparitic calcite. Sample PFZ-129.

Figure 9. Biocalcilutite with planktonic foraminifera and ostracod fragment. Sample PFZ-129.

Figure 10. Echinoid spine. Sample PFZ-129.

Figure 11. Echinoid spine. Sample PFZ-129.

Figure 12. Biserial foraminifera. Sample PFZ 129.

Figure 13. Biocalcilutite with recrystallized mollusk fragment and calcisphere. Sample PFZ 129.

Scale Bar $=400$ microns for all figures. 
PLATE 27
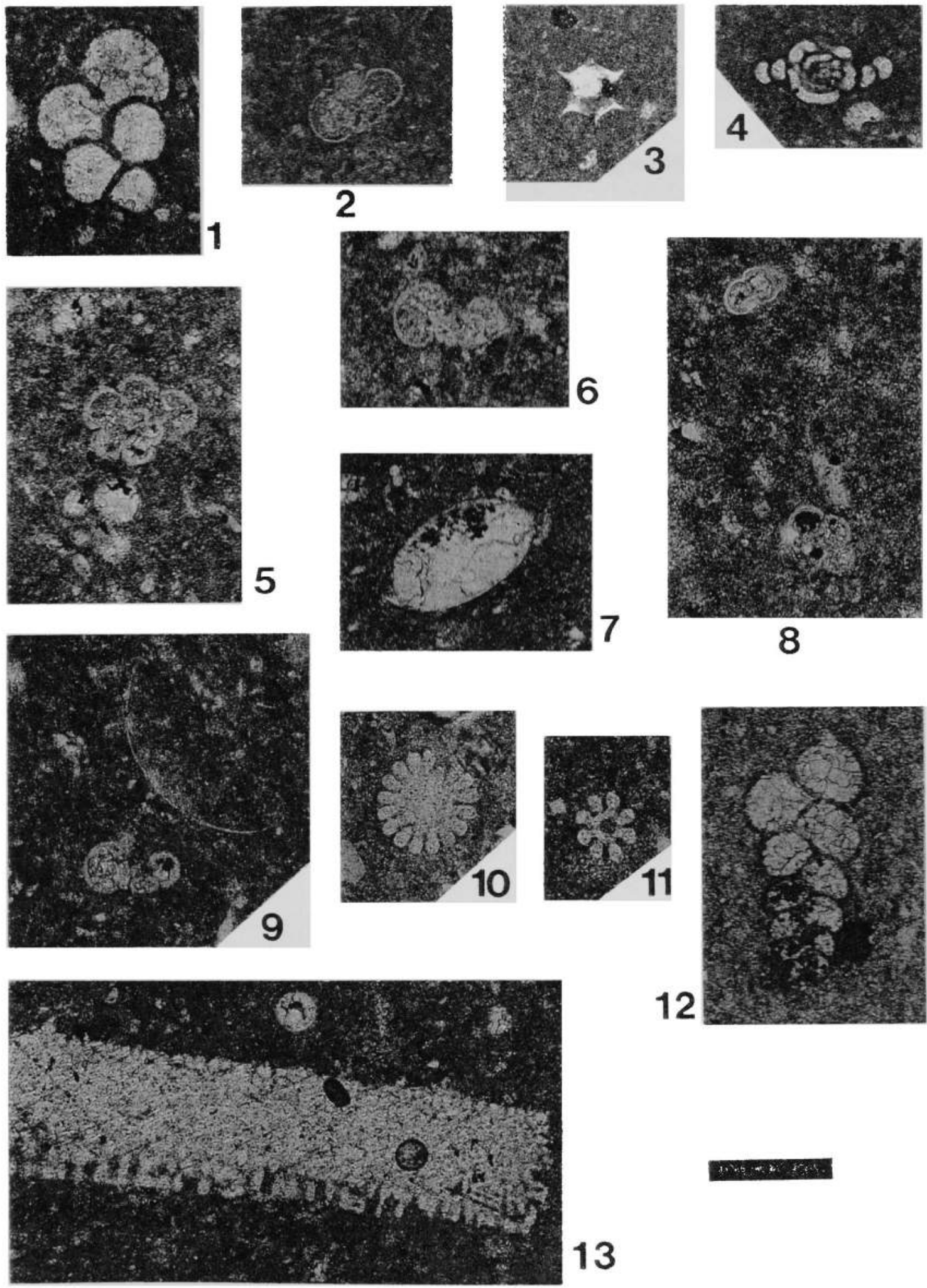

12

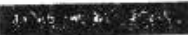

13 
PLATE 28. La Peña Formation, Presa Francisco Zarco (Subunit PFZ

Figure 1. Biocalcilutite with radiolaria. Sample PFZ-130. Scale Bar $=400$ microns.

Figure 2. Biocalcilutite with planktonic foraminifera and echinoid fragments. Sample PFZ-134. Scale Bar $=400$ microns.

Figure 3. Fragment of a phragmocone of an ammonite. Sample PFZ-136a. Scale $\mathrm{Bar}=1000$ microns.

Figure 4. Biocalcilutite with planktonic foraminifera, terrigenous materials, echinoid and mollusk fragments. Sample PFZ-136a. Scale Bar $=400$ microns.

Figure 5. Biocalcilutite with planktonic foraminifera and terrigenous materials. Sample PFZ-136b. Scale Bar $=400$ microns. 
PLATE 28
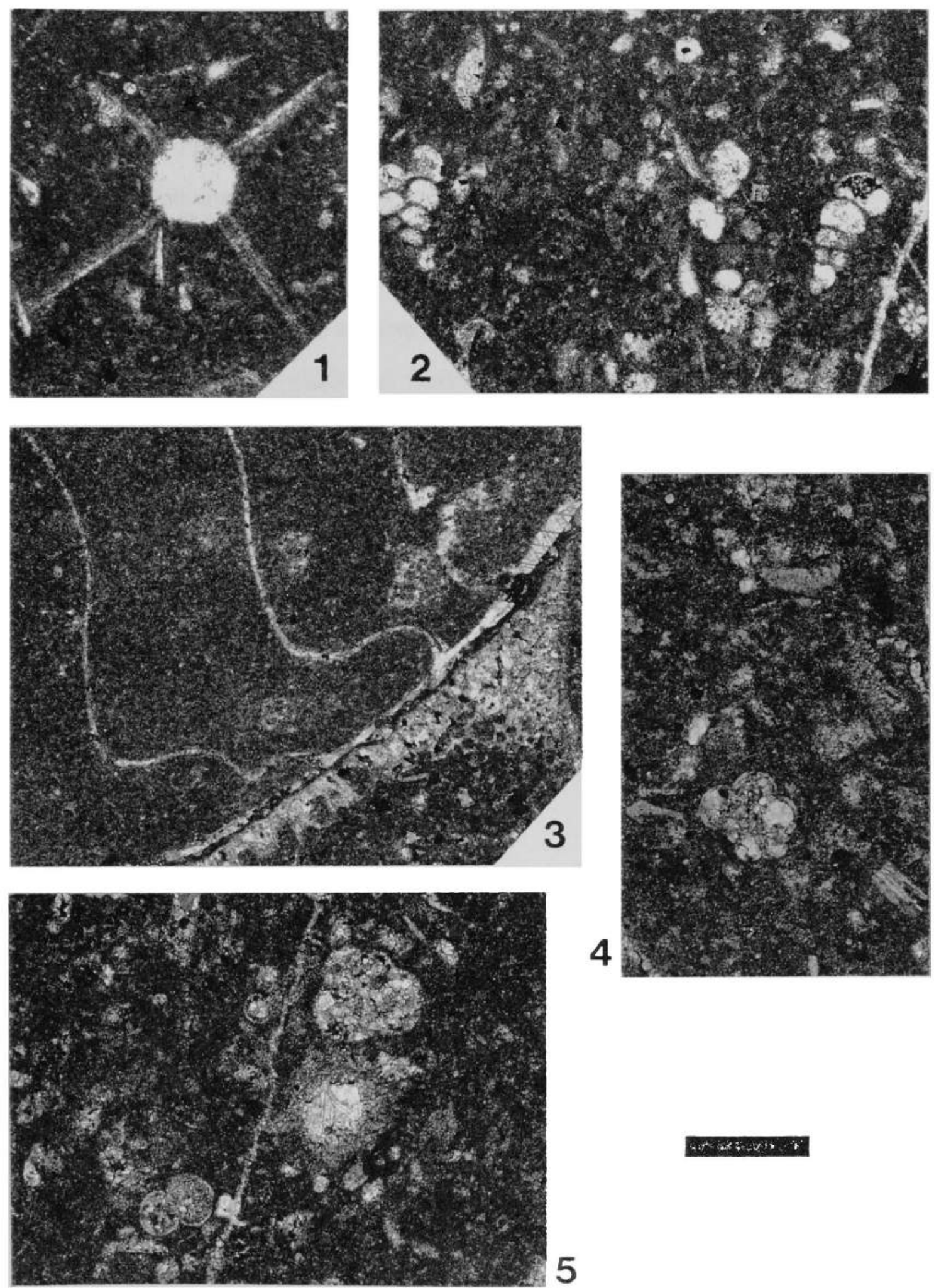


\section{PLATE 29. La Peña Formation, Presa Francisco Zarco (Subunit PFZ-1)}

Figure 1. Dolostone. Note the rhombic crystals of the dolomite.

Sample PFZ-137. Scale Bar $=400$ microns.

Figure 2. Biocalcilutite with planktonic foraminifera, echinoid and mollusk fragments. Sample PFZ -138 . Scale Bar $=400$ microns.

Figure 3. Biocalcilutite with planktonic foraminifera, mollusk and echinoid fragments. Sample PFZ -138 . Scale $\mathrm{Bar}=400$ microns.

Figure 4. Planktonic foraminifera. Sample PFZ-138. Scale Bar $=400$ microns.

Figure 5. Planktonic foraminifera. Sample PFZ-142a. Scale Bar $=400$ microns.

Figure 6. Biocalcilutite with planktonic foraminifera, mollusk and echinoid fragments, and terrigenous materials. Sample PFZ-142a. Scale Bar $=400$ microns.

Figure 7. Fragment of the phragmocone of an ammonite.

Sample PFZ 142a. Scale Bar $=1000$ microns. 

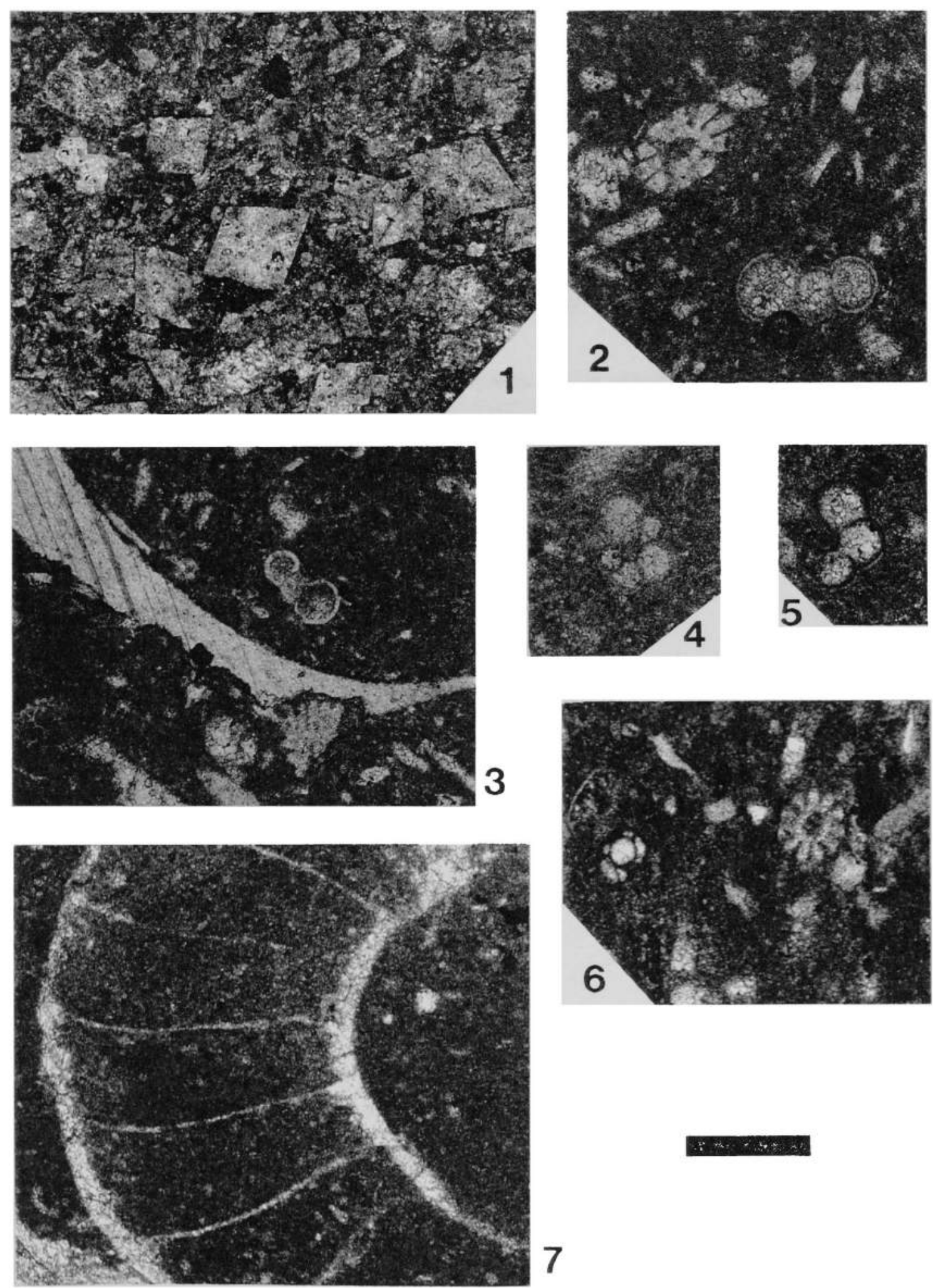
Figure 1. Planktonic foraminifera. Sample PFZ-142b. Scale Bar $=400$ microns.

Figure 2. Planktonic foraminifera. Sample PFZ-142b. Scale Bar $=400$ microns

Figure 3. Benthonic foraminifera. Sample PFZ $142 \mathrm{~b}$. Scale Bar $=400$ microns.

Figure 4. Fragment of the phragmocone of an ammonite. Sample PFZ-143a. Scale Bar $=1000$ microns.

Figure 5. Partially dolomitic biocalcilutite with planktonic foraminifera and mollusk fragments. Note thombic dolomite crystals. Sample PFZ-143b.

Scale $\mathrm{B}$ ar $=400$ microns.

Figure 6. Peloidal calcilutite. Note patches of sparry calcite cement. Sample $\mathrm{PFZ}-143 \mathrm{c}$. Scale Bar $=800$ microns.

Figure 7. Biocalcilutite with planktonic foraminifera. Note microveins flled with calcite. Sample PFZ-144a. Scale Bar $=400$ microns.

Figure 8. Planktonic foraminifera. Sample PFZ 144 a. Scale Bar $=400$ microns. 
PLATE 30
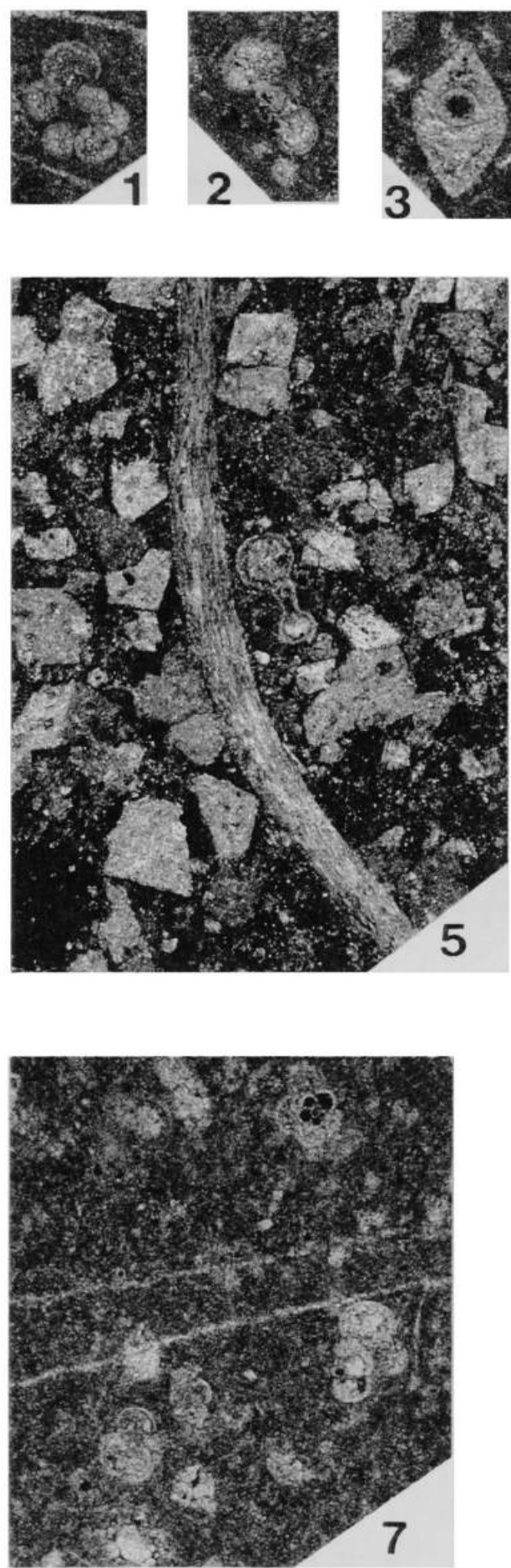
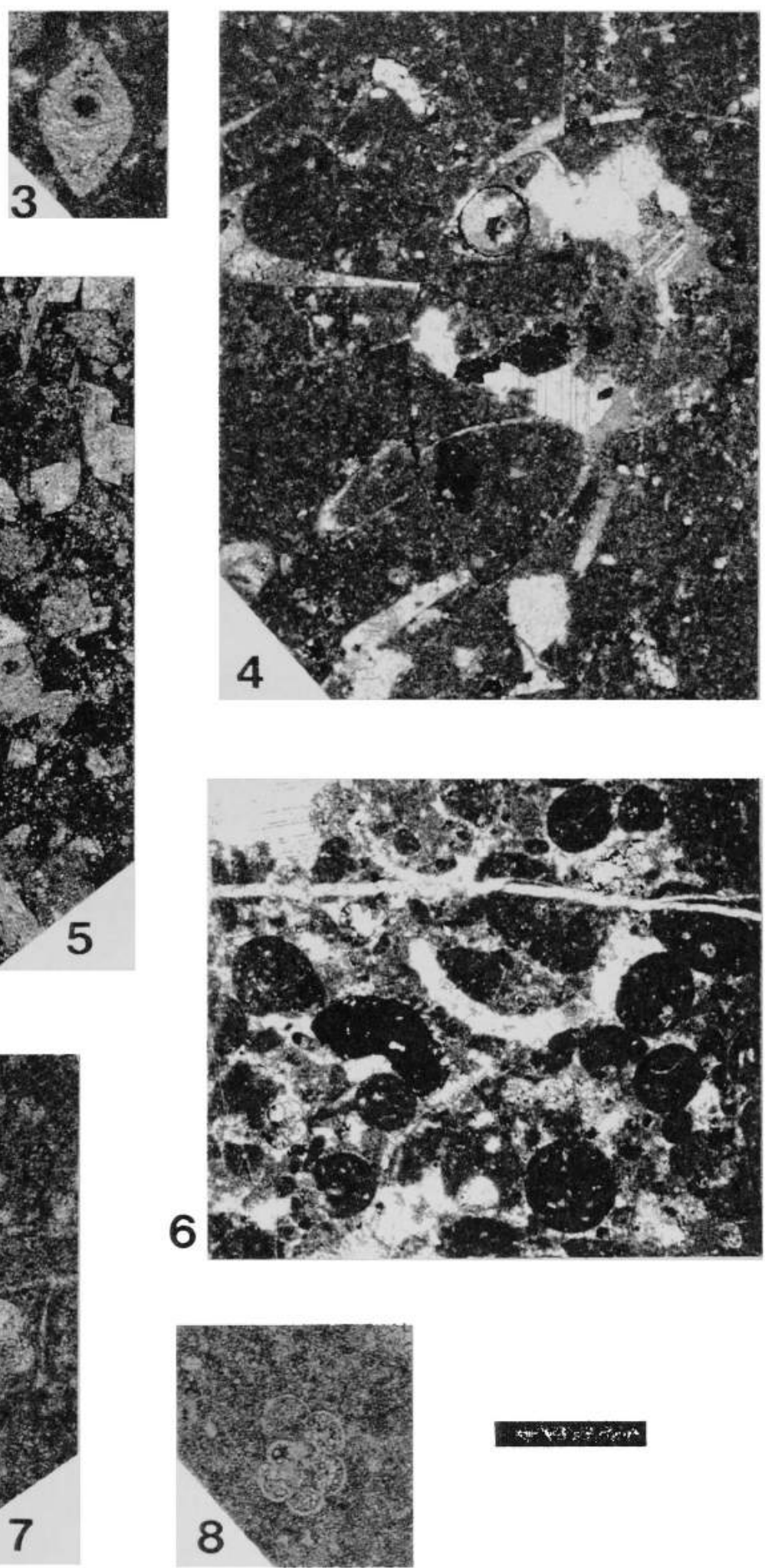


\section{PLATE 31. La Peña Formation, Presa Francisco Zarco (Subunit PFZ-1)}

Figure 1. Benthonic (?) foraminifera. Sample PFZ-144a. Scale Bar $=400$ microns.

Figure 2. Planktonic foraminifera. Sample PFZ-144a. Scale Bar $=400$ microns

Figure 3. Planktonic foraminifera. Sample PFZ-144a. Scale Bar $=400$ microns

Figure 4. Planktonic foraminifera. Sample PFZ-144a. Scale Bar $=400$ microns

Figure 5. Biocalcilutite with planktonic foraminifera and mollusk fragments Sample PFZ -146 . Scale Bar $=400$ microns.

Figure 6. Planktonic foraminifera.(cf. Globuligerina) Sample PFZ-154. Scale $\mathrm{Bar}=400$ microns

Figure 7. Planktonic foraminifera (Globigerinelloides). Sample PFZ-154. Scale $\mathrm{Bar}=400$ microns

Figure 8. Planktonic foraminifera (Globigerinelloides). Sample PFZ-160. Scale $\mathrm{Bar}=400$ microns.

Figure 9. Biocalcilutite with planktonic foraminifera. Sample PFZ-160. Scale Bar $=400$ microns.

Figure 10. Biocalcilutite with ammonite and echinoid fragments, and terrigenous materials. Sample PFZ-162a. Scale Bar $=1000$ microns.

Figure 11. Biocalcilutite with planktonic foraminifera. Note the diagenetic microvein. Sample PFZ $162 \mathrm{a}$. Scale Bar $=400$ microns. 
PLATE 31
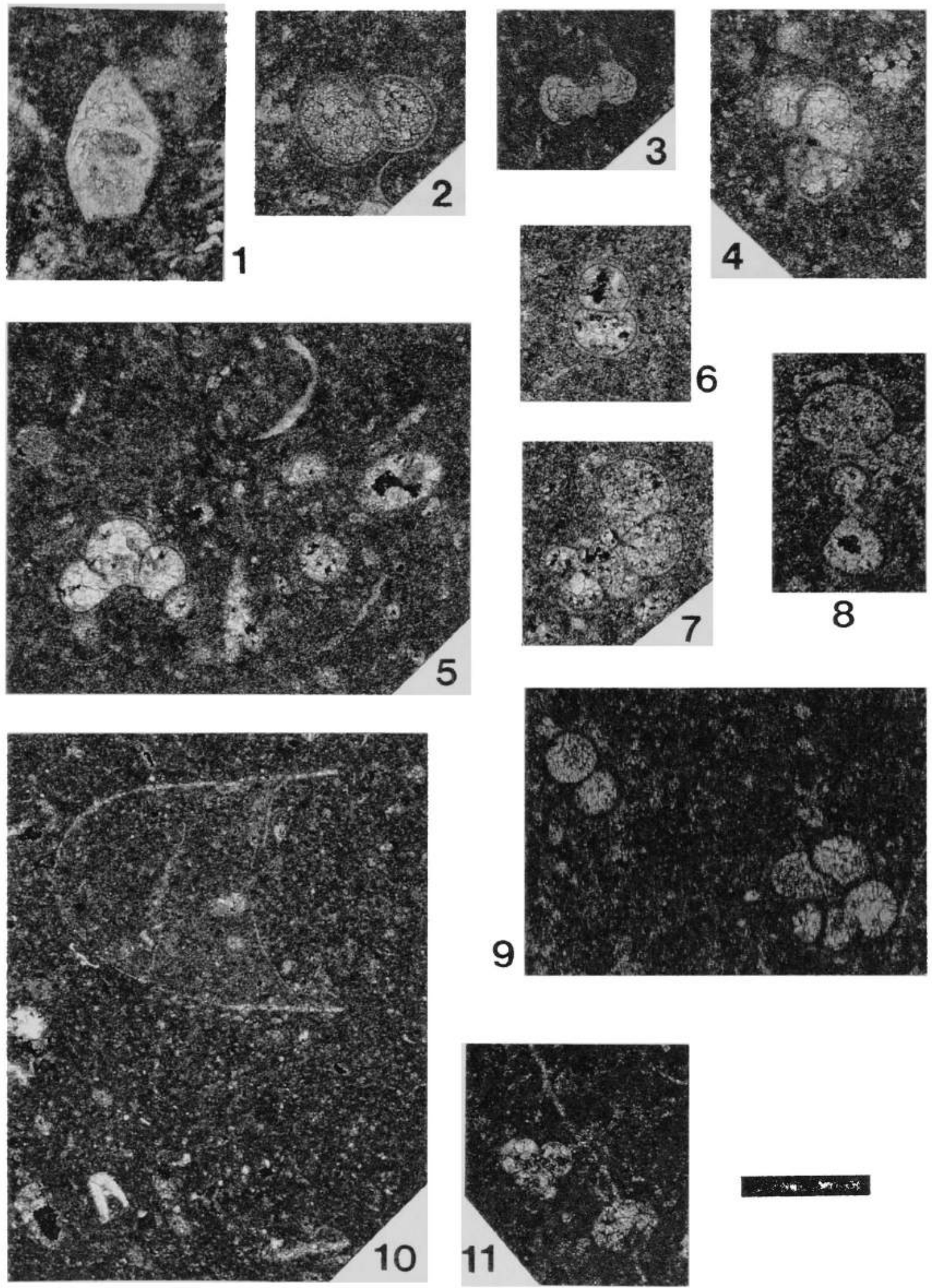
PLATE 32. La Peña Formation, Presa Francisco Zarco (Subunit PFZ-J)

Figure 1. Sparse radiolarian-peloidal biocalcilutite with terrigenous materials. Sample PFZ-162c. Scale Bar $=1000$ microns.

Figure 2. Packed radiolarian-peloidal biocalcilutite with planktonic foraminifera. Sample PFZ-164. Scale Bar $=800$ microns.

Figure 3. Sparse radiolarian-peloidal biocalcilutite with terrigenous materials. Sample PFZ 164. Scale Bar $=1000$ microns.

Figure 4. Planktonic foraminifera in a matrix composed of microspar and terrigenous materials. Sample PFZ-164. Scale Bar $=400$ microns

Figure 5. Sparse radiolarian-peloidal biocalcilutite with terrigenous materials. Note the apparent high concentration of organic matter.

Sample PFZ-171a. Scale Bar $=1000$ microns. 
PLATE 32
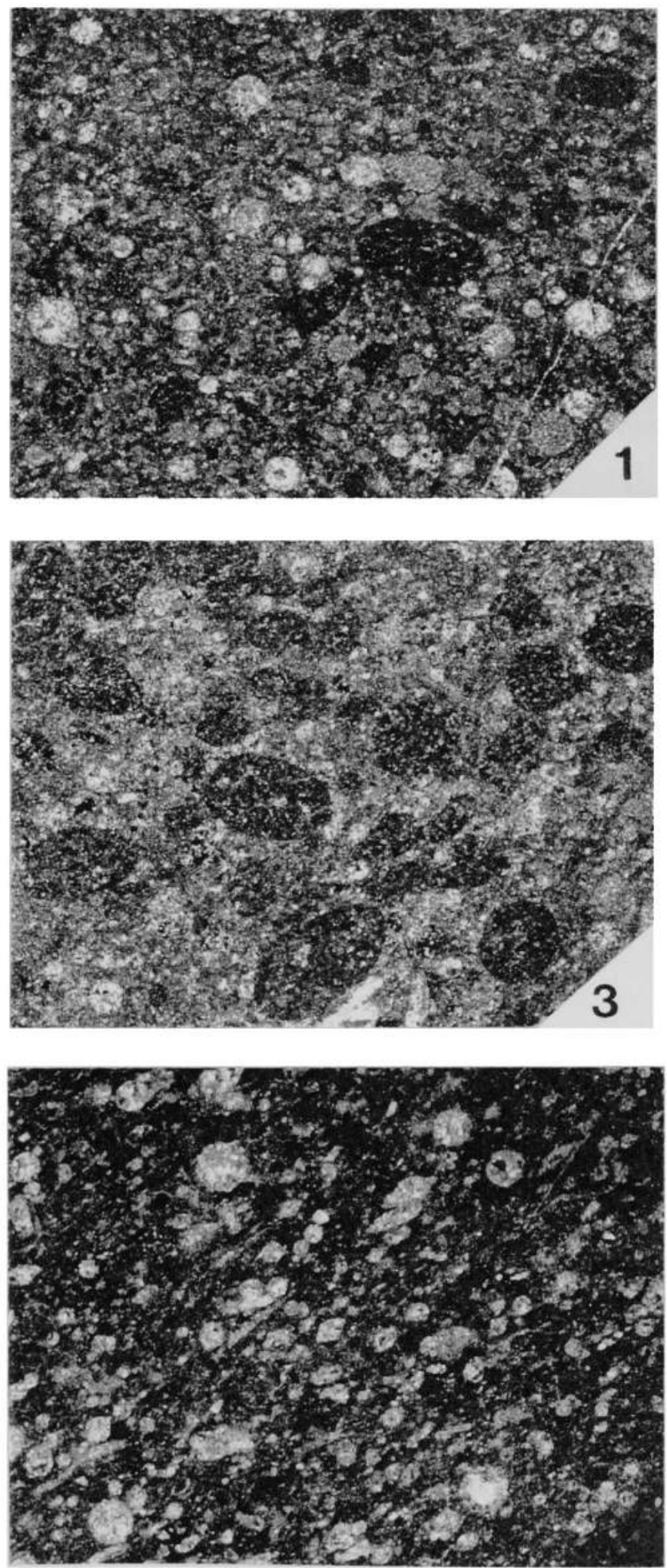
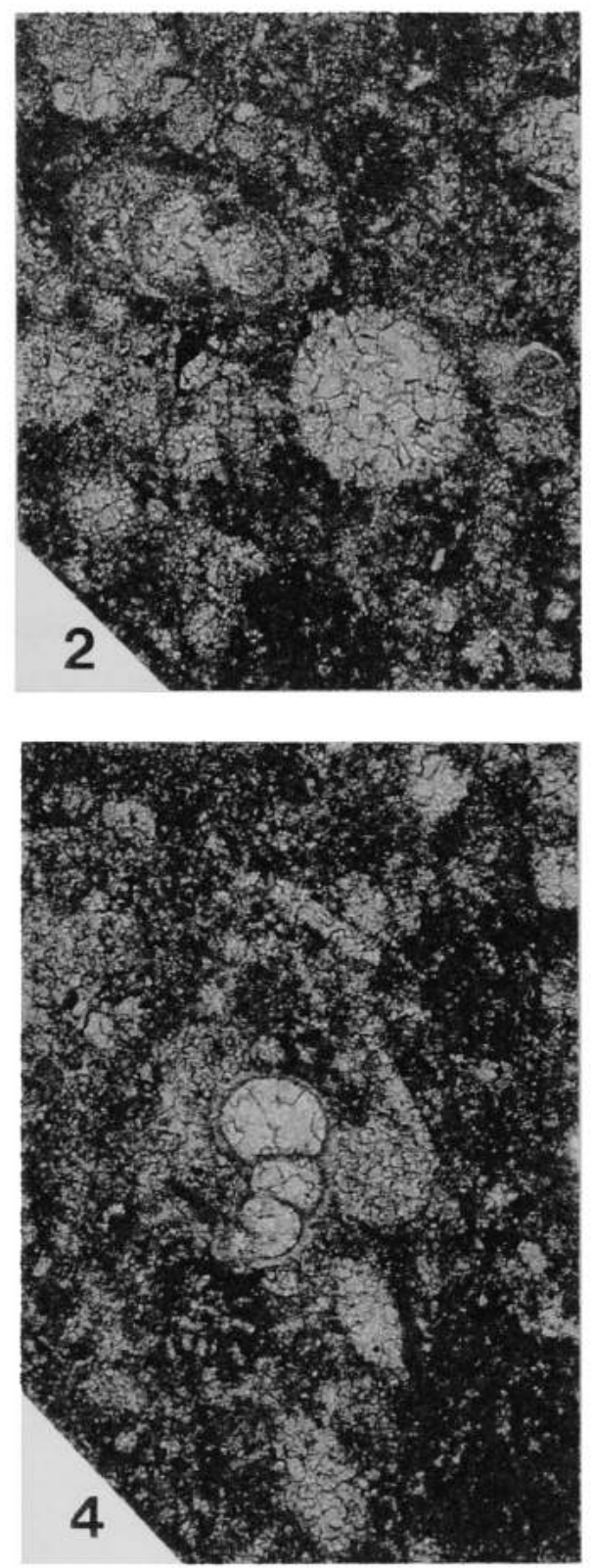

5 


\section{PLATE 33. La Peña Formation, Presa Francisco Zarco (Subunit PFZ-J)}

Figure 1. Biocalcilutite with planktonic foraminifera and terrigenous materials.

Sample PFZ 173 b. Scale Bar $=400$ microns.

Figure 2. Biocalcilutite with planktonic foraminifera and terrigenous materials. Sample PFZ-173b. Scale Bar $=400$ microns.

Figure 3. Biocalcilutite with planktonic foraminifera and terrigenous materials. Note the apparent high concentration of organic matter.

Sample PFZ-181. Scale Bar $=400$ microns.

Figure 4. Biocalcilutite with planktonic foraminifera and terrigenous materials. Note the apparent high concentration of organic matter. Sample PFZ -181 . Scale Bar $=400$ microns.

Figure 5. Planktonic foraminifera. Sample PFZ 182. Scale Bar $=400$ microns.

Figure 6. Peloidal calcilutite with terrigenous materials. Note microveins filled with calcite. Sample $\mathrm{PFZ}-182$. Scale Bar $=1000$ microns.

Figure 7. Planktonic foraminifera in a matrix mainly composed of terrigenous materials and microsparitic calcite. Sample PFZ-182. Scale Bar $=400$ microns.

Figure 8. Biocalcilutite with spumellarian radiolaria, peloids and terrigenous materials. Sample PFZ-183a. Scale Bar $=1000$ microns. 
PLATE 33
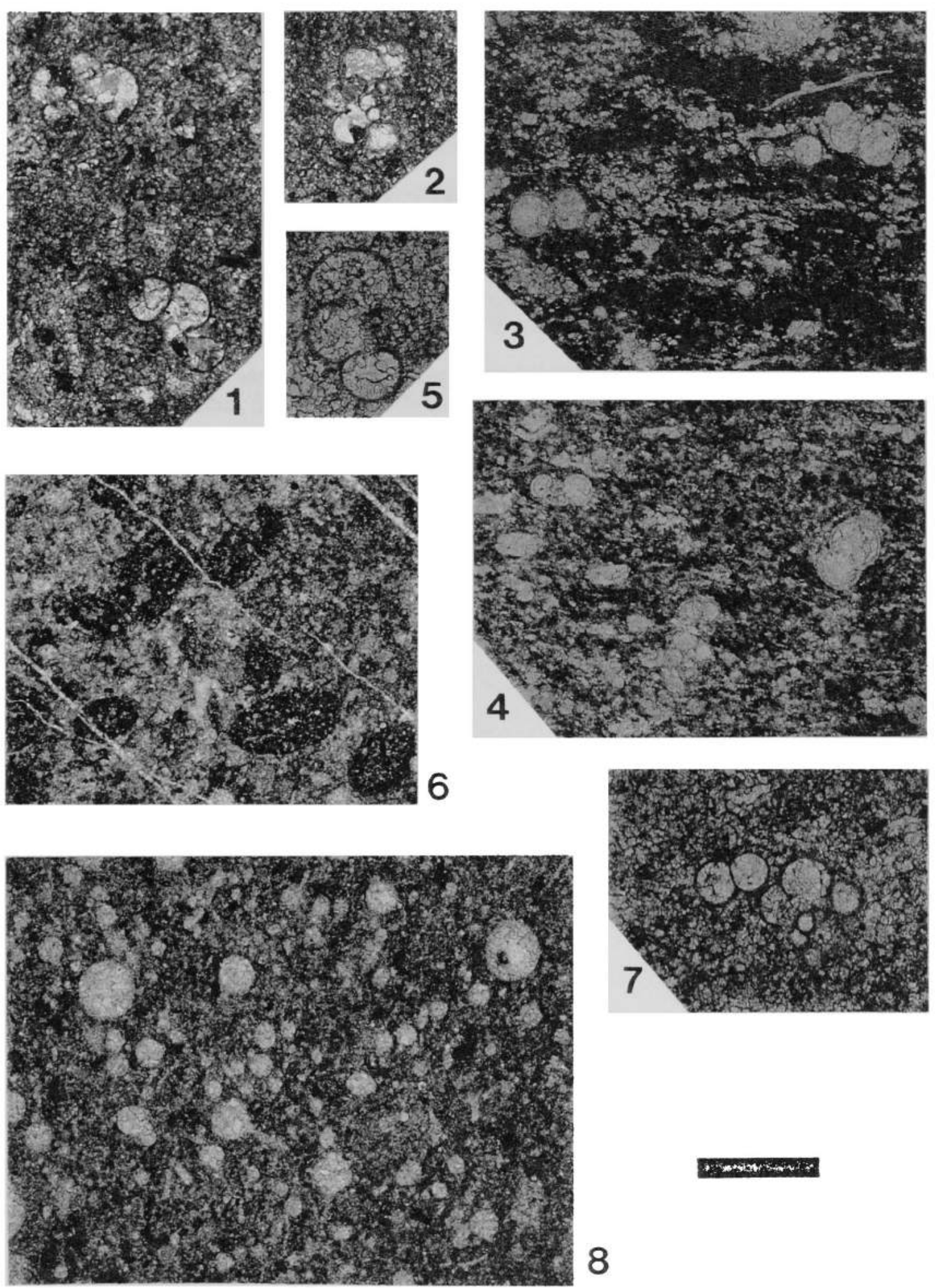


\section{PLATE 34. La Peña Formation, Presa Francisco Zarco (Subunit PFZ J J)}

Figure 1. Biocalcilutite with planktonic foraminifera and terrigenous materials.

Sample PFZ 187 . Scale Bar $=400$ microns.

Figure 2. Biocalcilutite with planktonic foraminifera and terrigenous materials. Sample PFZ-187. Scale Bar $=400$ microns.

Figure 3. Biocalcilutite with recrystallized radiolaria, planktonic foraminifera and peloids. Sample PFZ-188. Scale Bar $=1000$ microns.

Figure 4. Biocalcilutite with planktonic foraminifera and recrystallized mollusk fragments. Note the high concentration of terrigenous materials.

Sample PFZ-189a. Scale Bar $=400$ microns.

Figure 5. Biocalcilutite with planktonic foraminifera and apparent high concentration of organic matter. Sample PFZ $190 \mathrm{c}$. Scale Bar $=800$ microns.

Figure 6. Planktonic foraminifera (?). Sample PFZ-190c. Scale Bar $=400$ microns.

Figure 7. Planktonic foraminifera. (aff. Ticinella) Sample PFZ-191. Scale Bar $=400$ microns. 

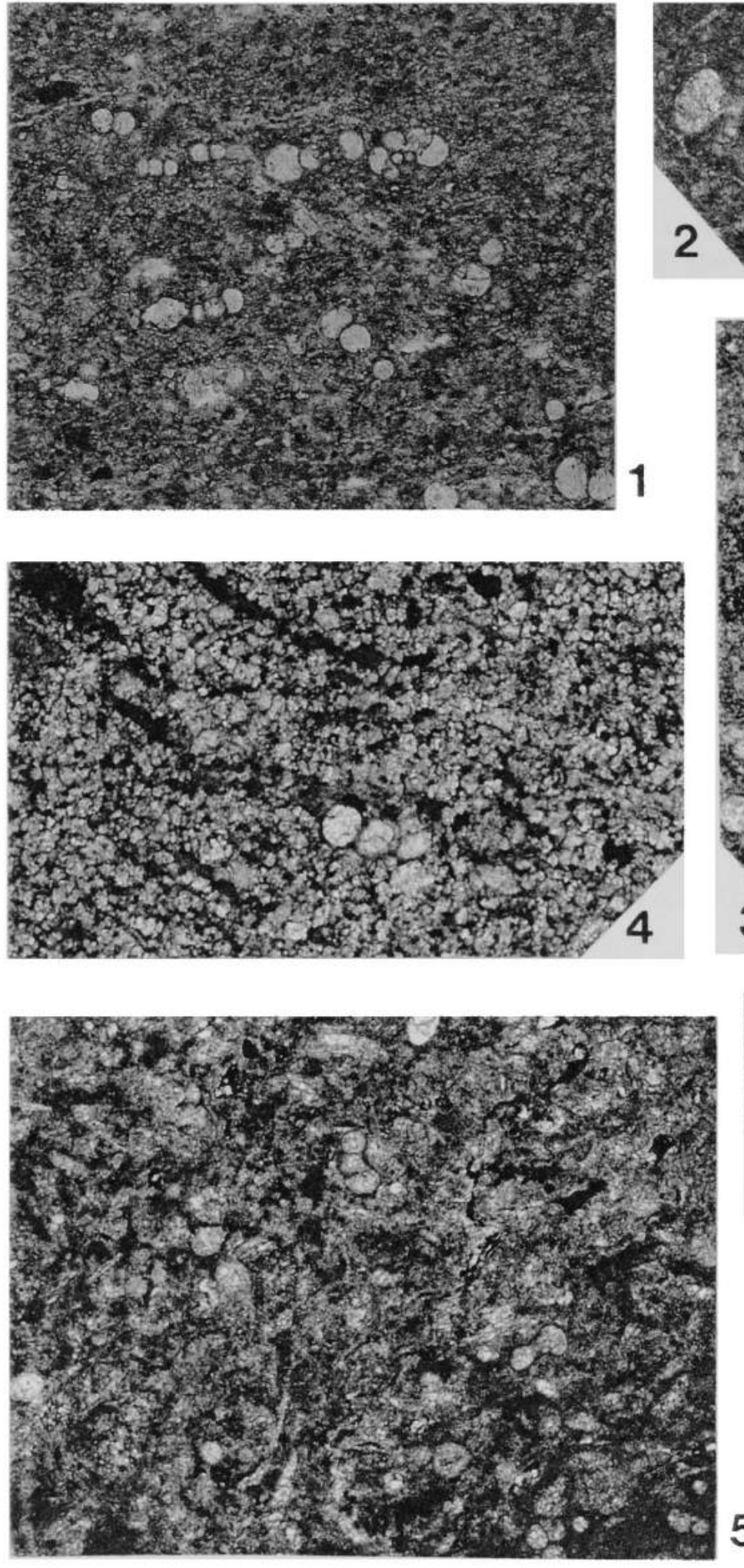
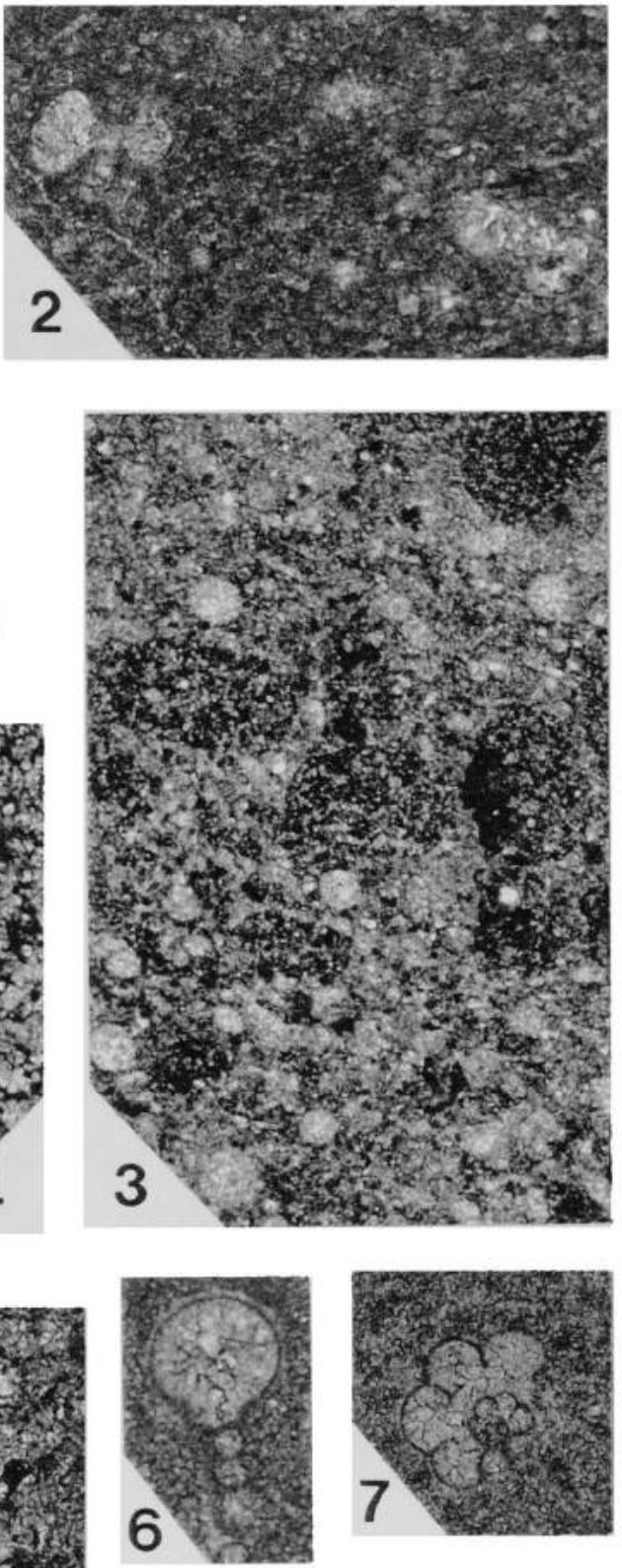

5 


\section{PLATE 35. La Peña Formation, Presa Francisco Zarco (Subunit PFZ-K)}

Figure 1. Biocalcilutite with mollusk fragments. Note the apparent high concentration of organic matter. Sample PFZ-192. Scale Bar $=400$ microns.

Figure 2. Biocalcilutite with planktonic foraminifera. Note the apparent high concentration of organic matter. Sample PFZ 192. Scale Bar $=400$ microns.

Figure 3. Biocalcilutite with tintinids and terrigenous materials. Matrix consists of microsparitic calcite. Sample PFZ-193. Scale Bar $=400$ microns.

Figure 4. Planktonic foraminifera. Ticinella sp. ?. Sample PFZ-193. Scale $\mathrm{Bar}=400$ microns.

Figure 5. Planktonic foraminifera. Ticinella sp. ?.Sample PFZ-193. Scale Bar $=400$ microns.

Figure 6. Tintinid. Sample PFZ-193. Scale Bar $=200$ microns.

Figure 7. Tintinid. Sample PFZ-193. Scale Bar $=200$ microns.

Figure 8. Biocalcilutite with planktonic foraminifera and recrystallized radiolaria.

Sample PFZ -195 . Scale Bar $=400$ microns. 
PLATE 35
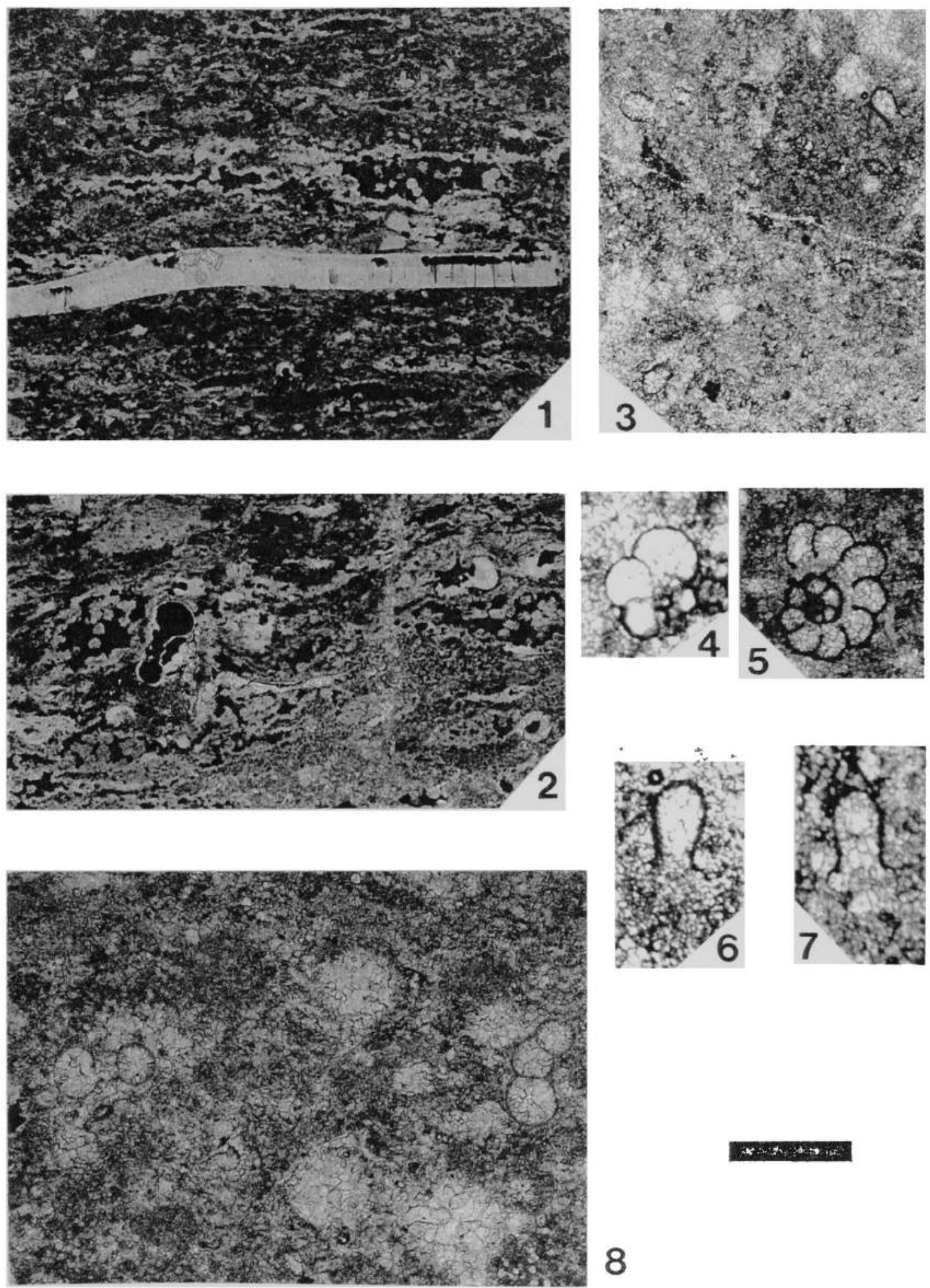

8 


\section{PLATE 36. La Peña Formation, Presa Francisco Zarco (Subunit PFZ-K)}

Figure 1. Biocalcilutite with planktonic foraminifera and recrystallized radiolaria, Note the apparent high concentration of organic matter and terrigenous materials.

Sample PFZ-198.

Figure 2. Biocalcilutite with planktonic foraminifera and recrystallized radiolaria. Note the apparent high concentrations of organic matter and terrigenous materials. Sample PFZ-200.

Figure 3. Biocalcilutite with radiolaria. Matrix mainly composed of terrigenous materials and microsparitic calcite. Sample PFZ-201.

Figure 4. Biocalcilutite with planktonic foraminifera and recrystallized radiolaria. Note microfracture filled with calcite. Sample PFZ-203.

Scale $\mathrm{Bar}=400$ microns for all figures. 
PLATE 36

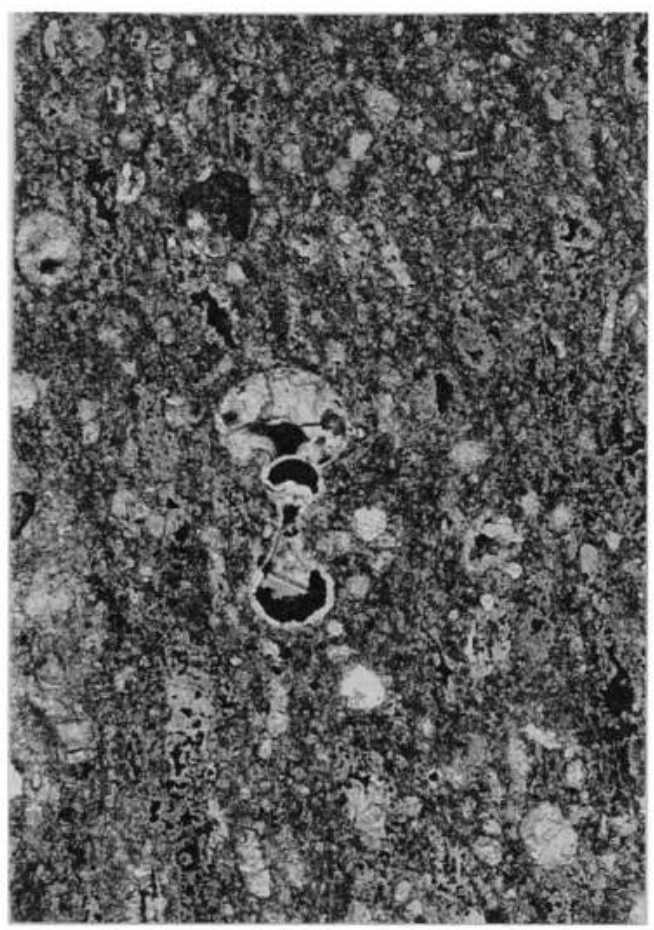

1

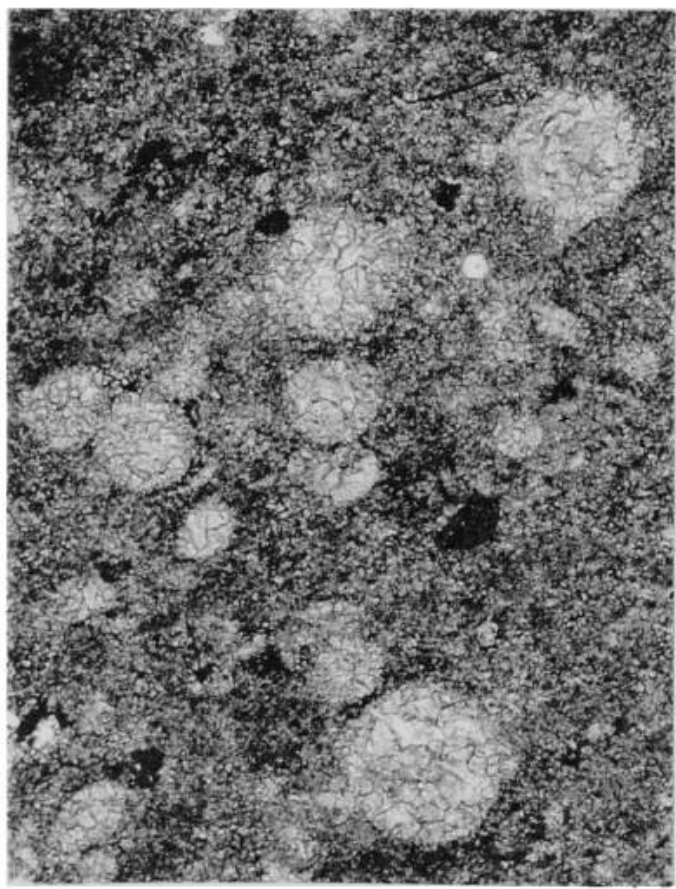

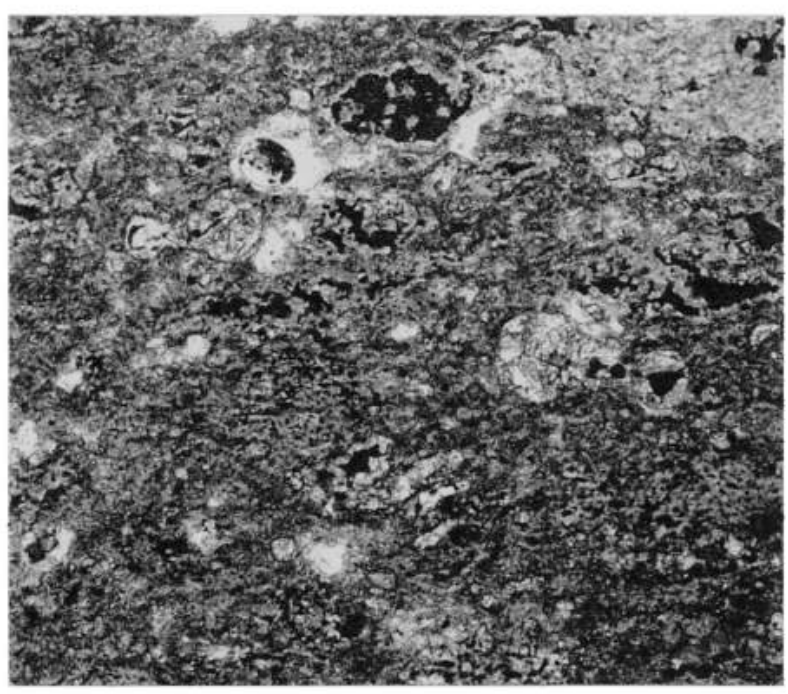

2

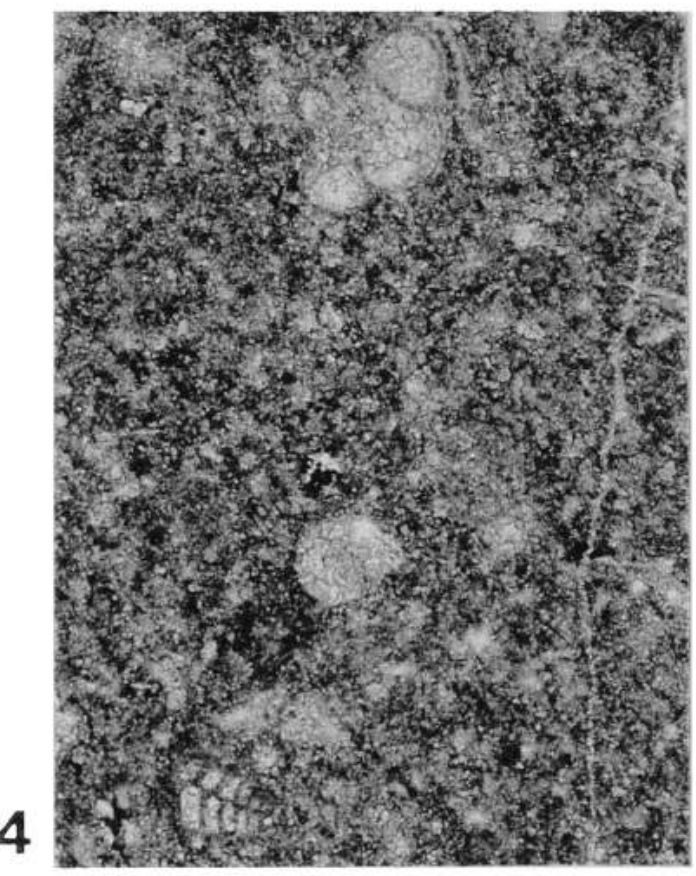

$4 x^{2}+x^{2}+x^{3}$ 


\section{PLATE 37. Lower Tamaulipas Formation, La Boca Canyon}

Figure 1. Biocalcilutite with planktonic foraminifera and intraclasts. Note that the intraclasts are made of echinoid and ostracod fragments.

Sample LB A-1. Scale Bar $=400$ microns.

Figure 2. Benthonic(?) foraminifera. Sample LB A-1. Scale Bar $=400$ microns.

Figure 3. Unidentified bioclast. Sample LB A-2. Scale Bar $=400$ microns.

Figure 4. Planktonic foraminifera. Sample A-2. Scale Bar $=400$ microns.

Figure 5. Recrystallized planktonic foraminifera. Sample LB A-2. Scale Bar $=200$ microns.

Figure 6. Biocalcilutite with ostracod and echinoid fragments.

Sample LB A-2. Scale Bar $=400$ microns.

Figure 7. Unidentified bioclast. Sample LB A-3b. Scale Bar $=400$ microns.

Figure 8. Planktonic foraminifera. Sample A-4a. Scale Bar $=400$ microns

Figure 9. Biocalcilutite with recrystallized radiolaria, mollusk and echinoid fragments.

Sample LB A $-4 b$. Scale Bar $=1000$ microns. 
PLATE 37
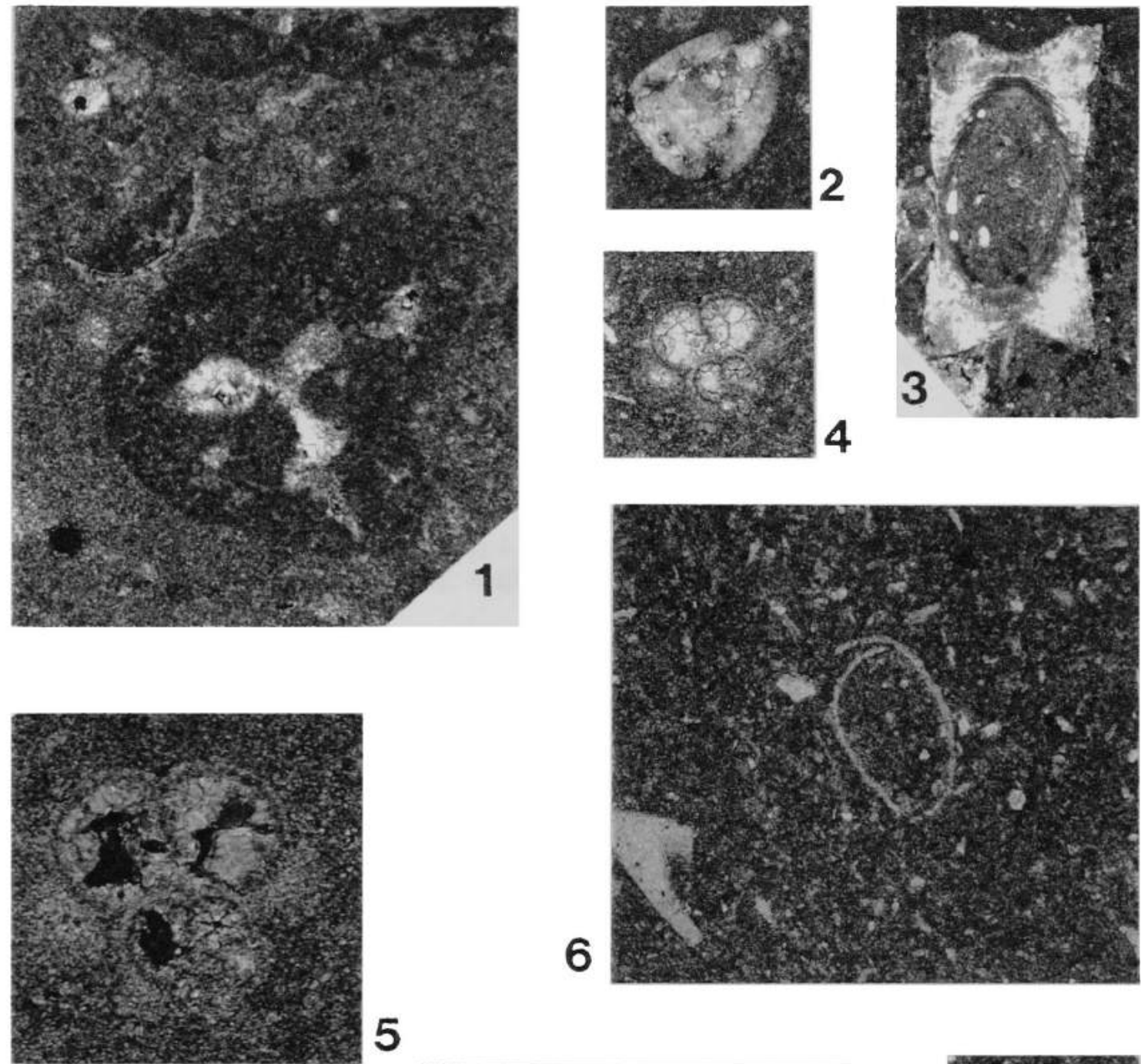

5
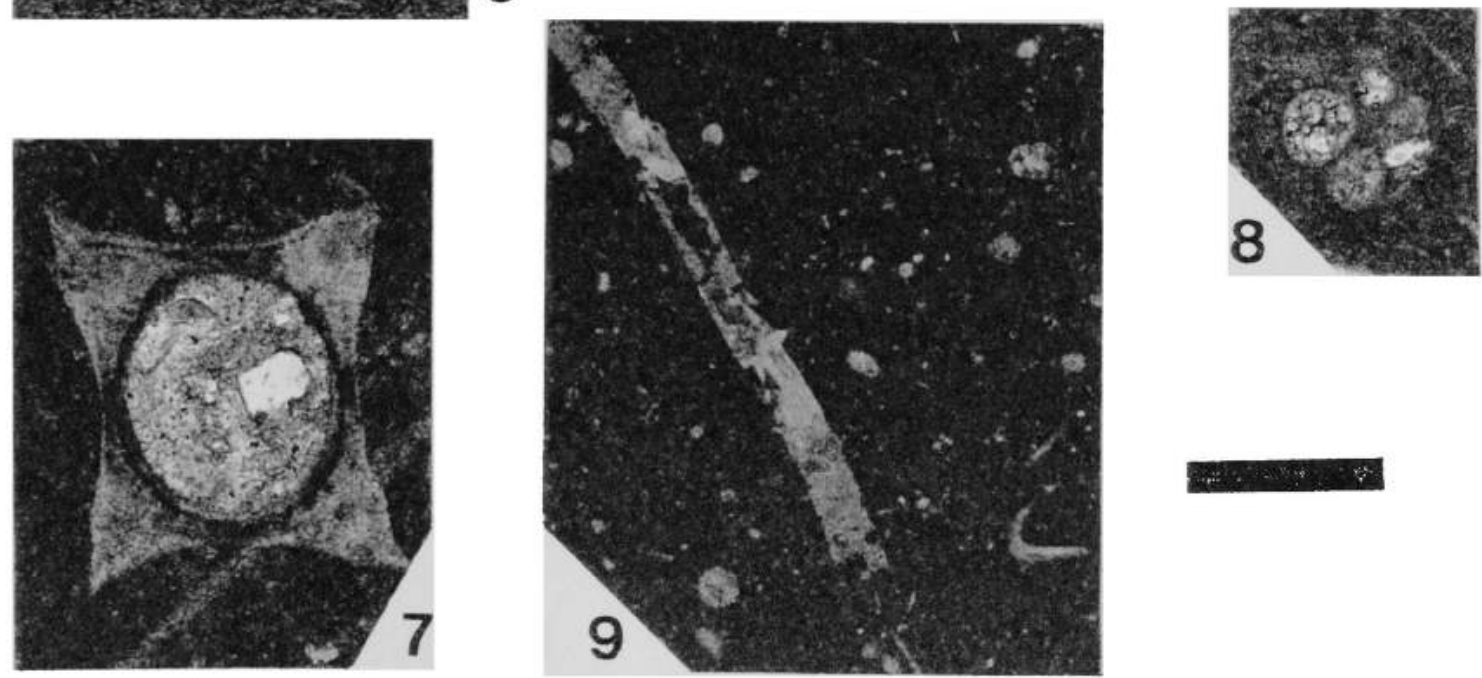


\section{PLATE 38. Lower Tamaulipas Formation, La Boca Canyon}

Figure 1. Biocalcilutite with recrystallized radiolaria, ostracod and echinoid fragments. Sample LB A-5. Scale Bar $=400$ microns.

Figure 2. Biocalcilutite with planktonic foraminifera, echinoid fragments, and terrigenous materials. Sample LB A-6a. Scale Bar $=400$ microns.

Figure 3. Planktonic foraminifera. Sample A-6a. Scale Bar $=200$ microns.

Figure 4. Planktonic foraminifera. Sample A-6a. Scale Bar $=200$ microns.

Figure 5. Planktonic foraminifera. Sample A -6a. Scale Bar $=200$ microns.

Figure 6. Ostracod. Sample A-6b. Scale Bar $=400$ microns.

Figure 7. Ostracod. Sample A-6b. Scale Bar $=400$ microns.

Figure 8. Biocalcilutite with planktonic foraminifera, and echinoid and ostracod fragments. Sample LB A-7. Scale Bar $=400$ microns.

Figure 9. Planktonic foraminifera. Sample A-7. Scale Bar $=200$ microns 
PLATE 38
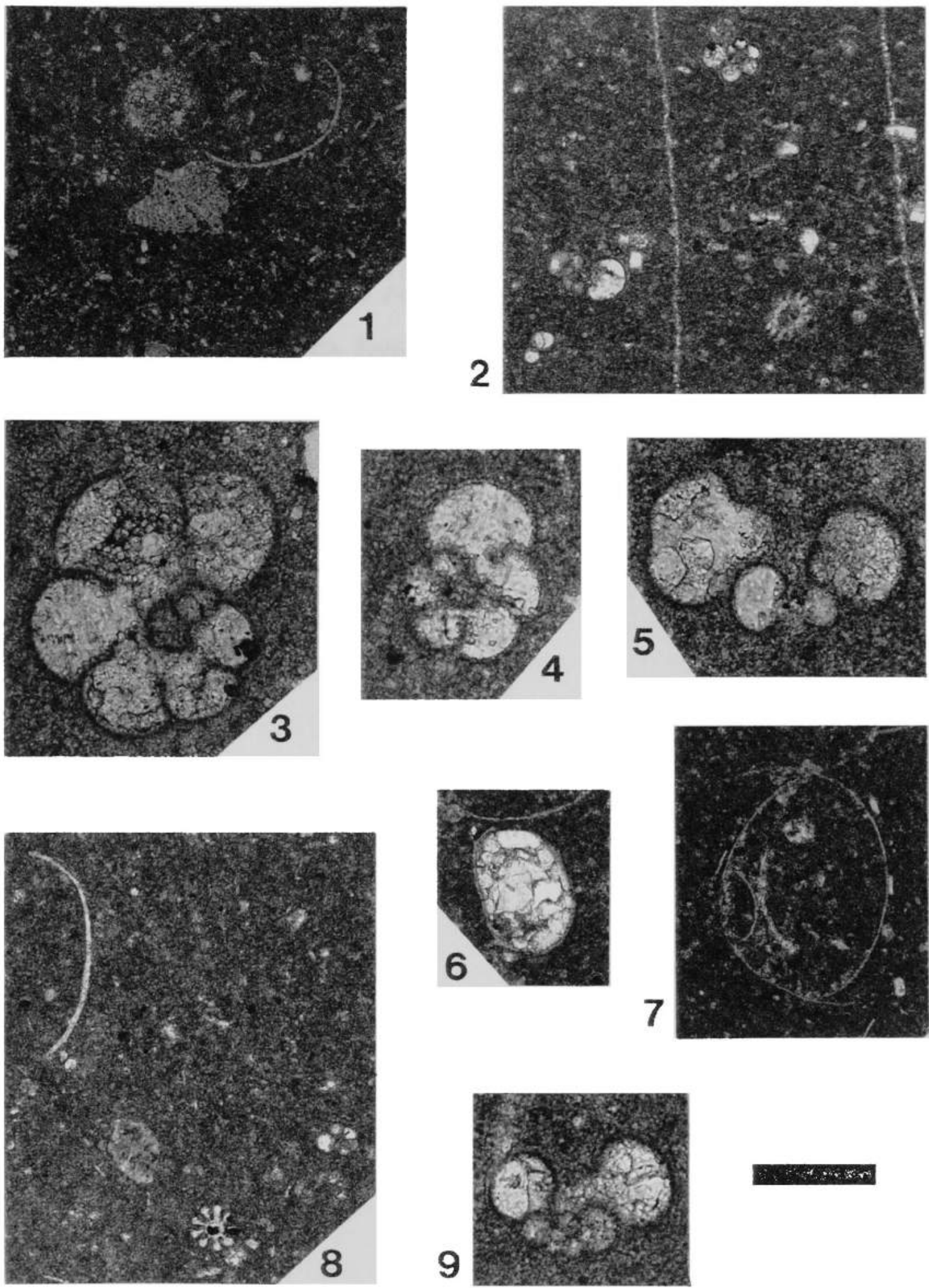
Figure 1. Planktonic foraminifera. Sample LB A-7. Scale Bar $=200$ microns.

Figure 2. Planktonic foraminifera. Sample LB A-7. Scale Bar $=200$ microns.

Figure 3. Planktonic foraminifera. Sample A-9. Scale Bar $=200$ microns.

Figure 4. Biocalcilutite with planktonic foraminifera and echinoid fragments. Sample LB A-9. Scale Bar $=400$ microns.

Figure 5. Biocalcilutite with planktonic foraminifera.

Sample A-10c, Scale Bar $=400$ microns.

Figure 6. Planktonic foraminifera. Sample LB A-11. Scale Bar $=200$ microns.

Figure 7. Biocalcilutite with planktonic foraminifera and benthonic foraminifera Sample LB A-11. Scale Bar $=400$ microns. 
PLATE 39

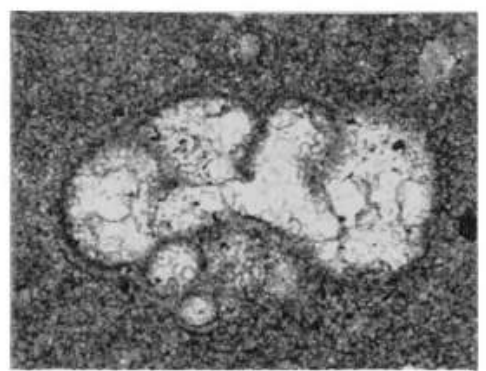

1

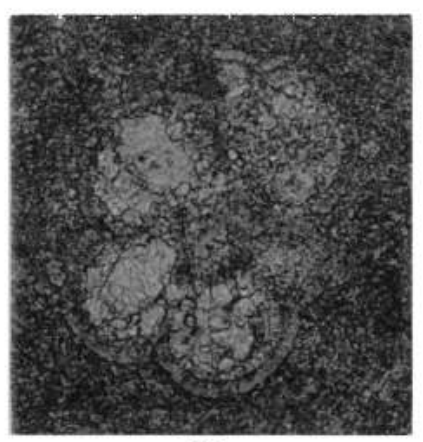

2

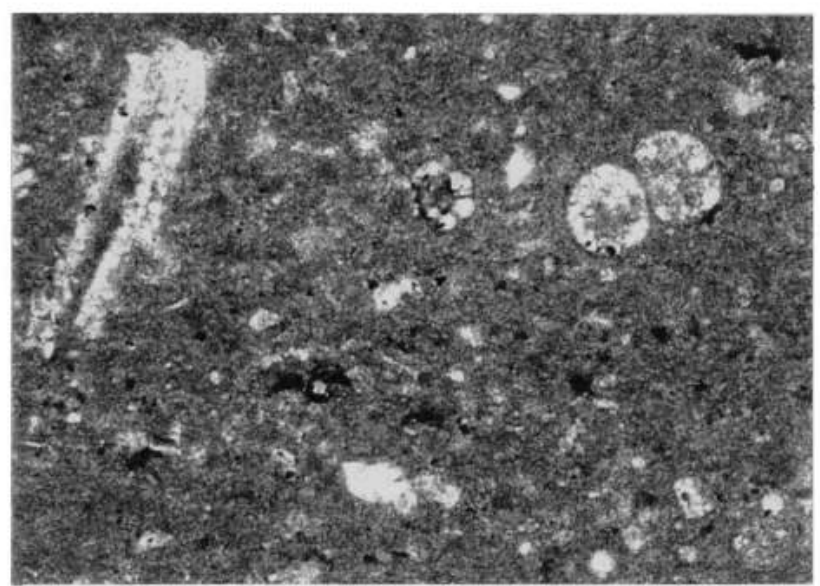

4

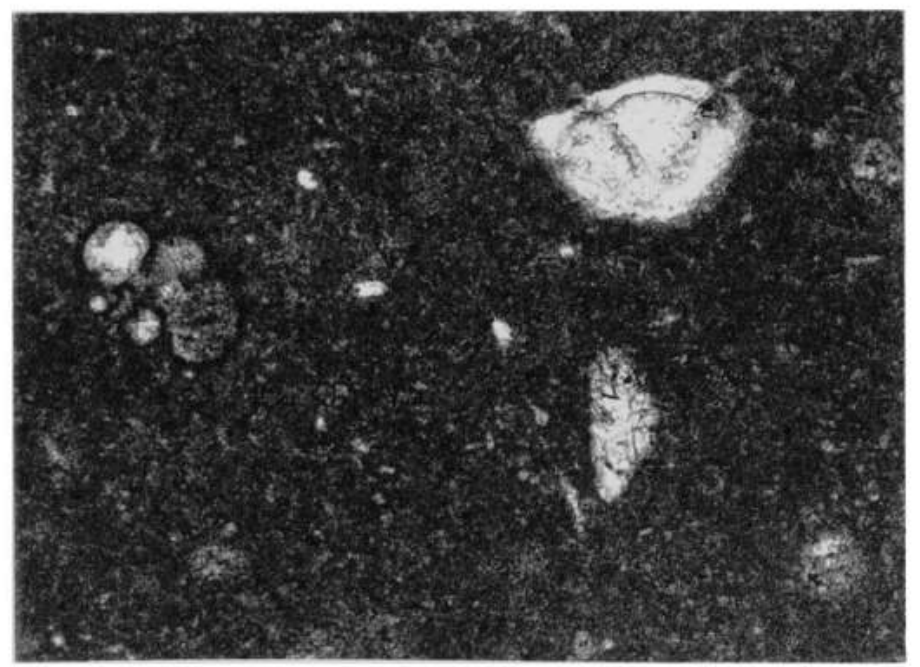

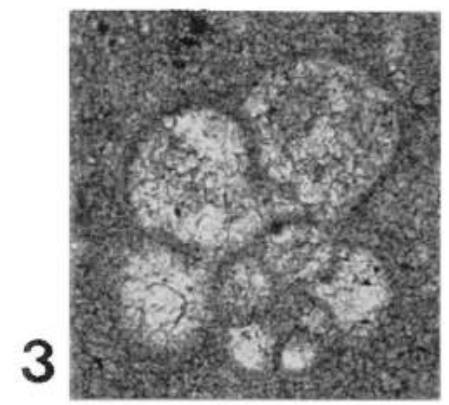

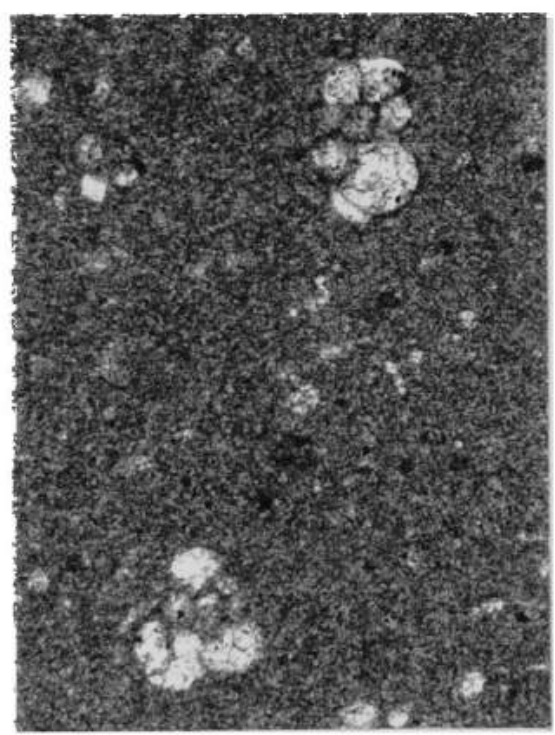

5

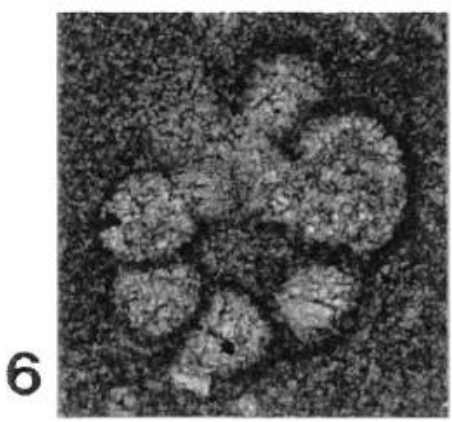


Figure 1. Planktonic foraminifera. Sample LB A-13. Scale Bar $=200$ microns.

Figure 2. Planktonic foraminifera. Sample LB A-13. Scale Bar $=200$ microns.

Figure 3, Ostracod. Sample LB A-13. Scale Bar $=400$ microns.

Figure 4. Planktonic foraminifera. Sample A-14. Scale Bar $=200$ microns.

Figure 5. Biocalcilutite with planktonic foraminifera and terrigenous materials. Note the diagenetic microvein. Sample A-17. Scale Bar $=400$ microns.

Figure 6. Planktonic foraminifera. Sample LB A-17. Scale Bar $=200$ microns.

Figure 7. Echinoid spine. Sample A-17. Scale Bar $=200$ microns.

Figure 8. Planktonic foraminifera. Sample A-19. Scale Bar $=200$ microns.

Figure 9. Benthonic foraminifera?. Sample A-21. Scale Bar $=200$ microns.

Figure 10. Benthonic foraminifera. Sample LB A-23. Scale Bar $=200$ microns.

Figure 11. Biocalcilutite with echinoid spine, ostracod fragment, and terrigenous materials. Sample LB A-23. Scale Bar $=400$ microns. 
PLATE 40
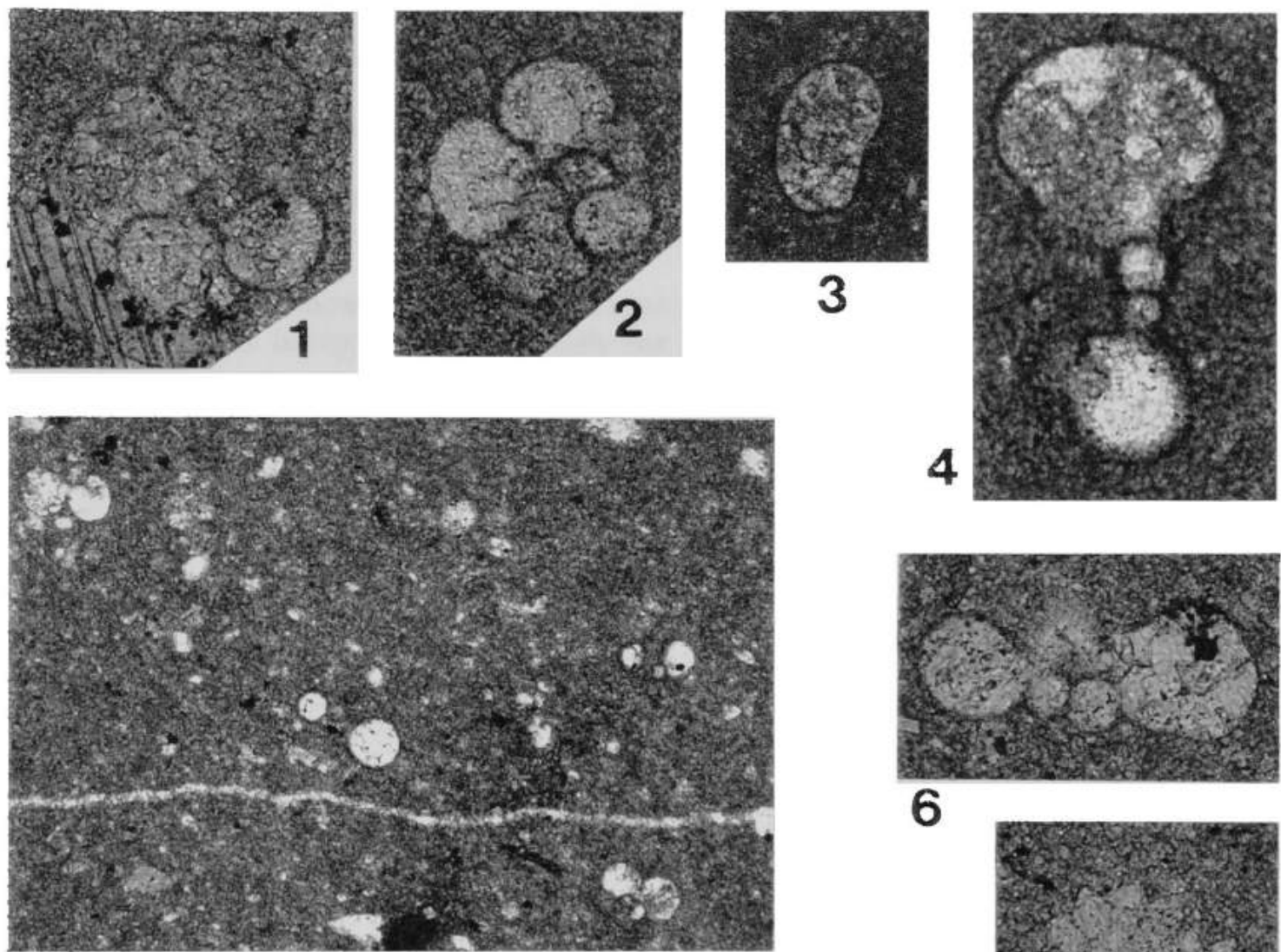

5
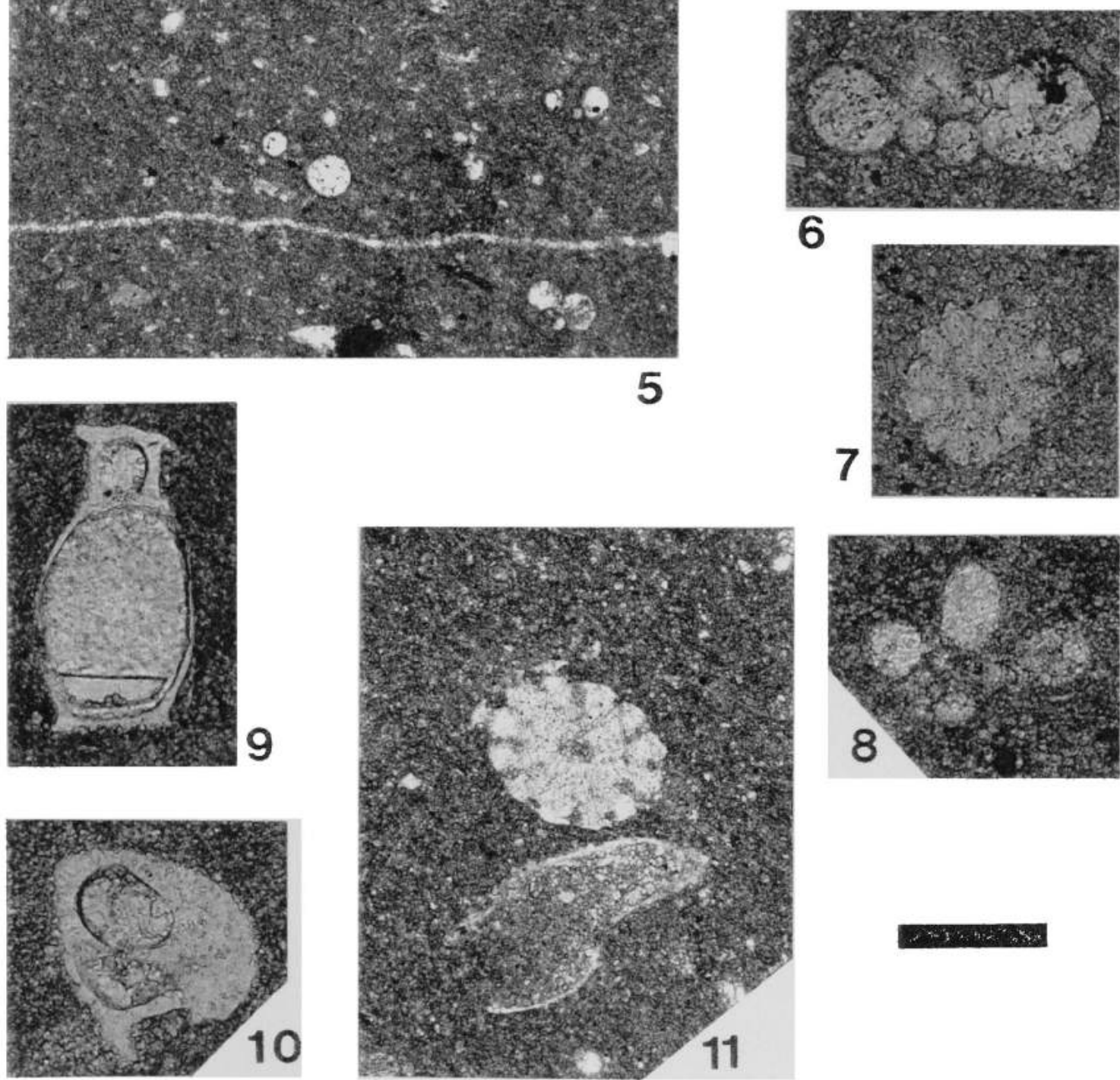

6
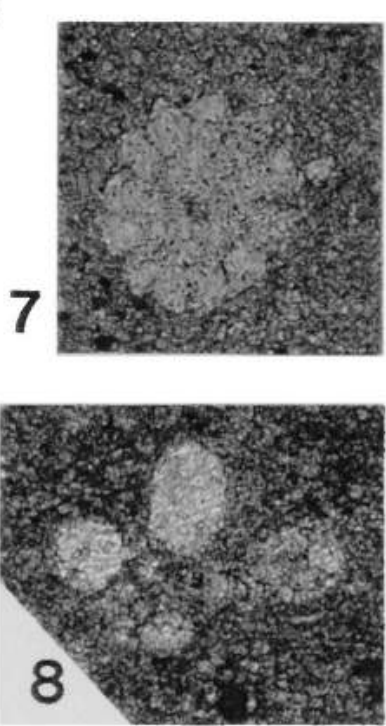


\section{PLATE 41. La Peña Formation, La Boca Canyon}

Figure 1. Benthonic foraminifera (Camernid). Sample LB A-23. Scale Bar $=200$ microns.

Figure 2. Planktonic foraminifera. Sample LB A-23. Scale Bar $=200$ microns.

Figure 3. Partially dolomitic biocalcilutite with planktonic foraminifera and abundant terrigenous materials. Sample LB A-24. Scale Bar $=400$ microns.

Figure 4. Dolomitic biocalcilutite with benthonic foraminifera (Camerinid) and terrigenous materials. Sample LB A-27. Scale Bar $=400$ microns.

Figure 5. Benthonic foraminifera (Camerinid). Sample LB A-28. Scale Bar $=200$ microns. 


\section{PLATE 41}
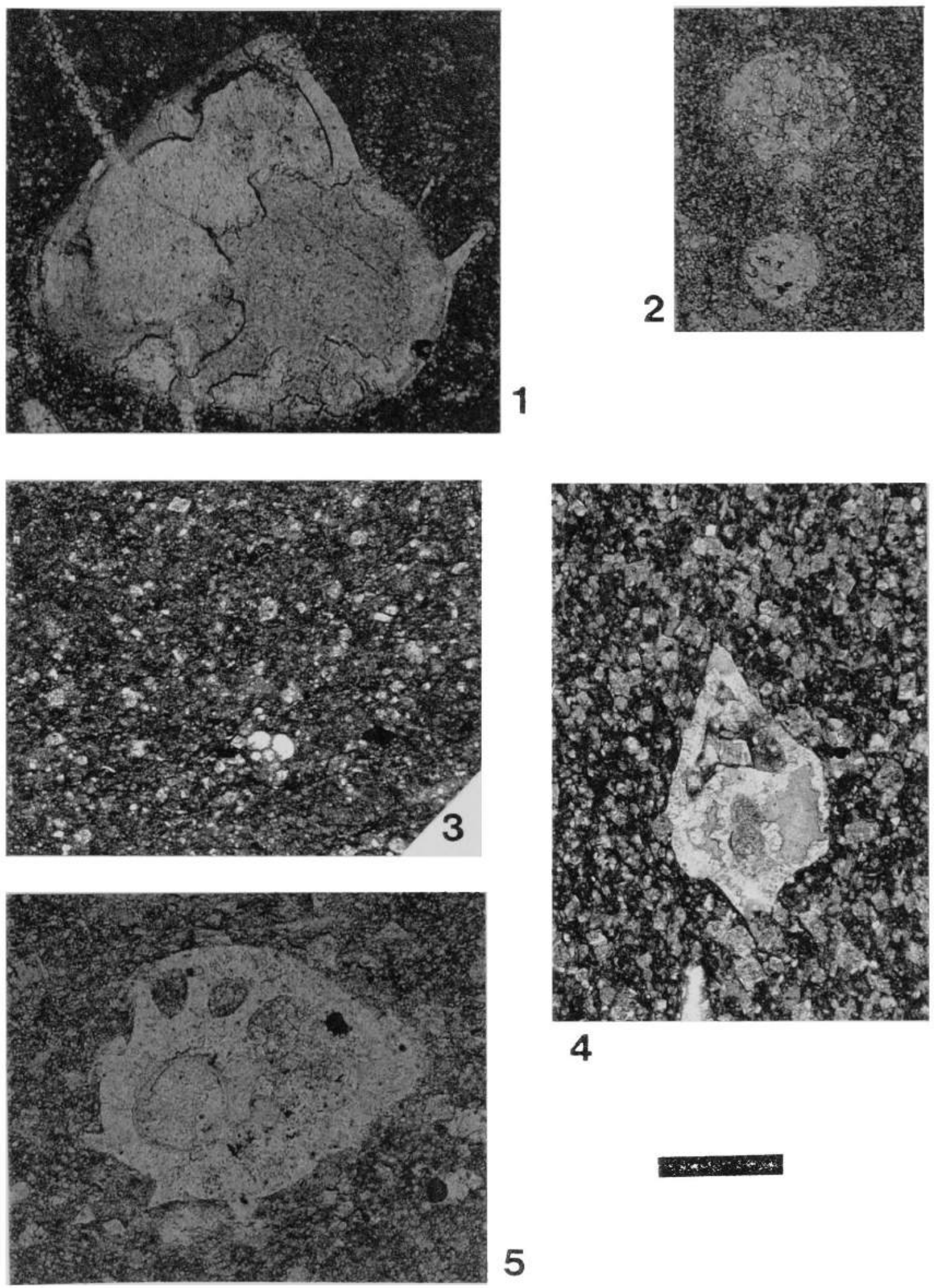

5 


\section{PLATE 42. La Peña Formation, La Boca Canyon}

Figure 1. Biocalcilutite with planktonic foraminifera and terrigenous materials.

Sample LB E-1. Scale Bar $=200$ microns.

Figure 2. Biocalcilutite with planktonic foraminifera, echinoid spines, and terrigenous materials. Sample LB E-1. Scale Bar $=400$ microns.

Figure 3. Biocalcilutite with planktonic foraminifera and recrystallized radiolaria. Sample LB E-6. Scale Bar $=400$ microns.

Figure 4. Biocalcilutite with planktonic foraminifera and terrigenous materials.

Note the apparent high concentration of organic matter.

Sample LB G-6. Scale Bar $=400$ microns.

Figure 5. Biocalcilutite with planktonic foraminifera and terrigenous materials.

Note the apparent high concentration of organic matter.

Sample LB G-14. Scale Bar $=400$ microns.

Figure 6. Benthonic foraminifera (Lenticulinid?).

Sample LB G-15. Scale Bar $=400$ microns. 
PLATE 42
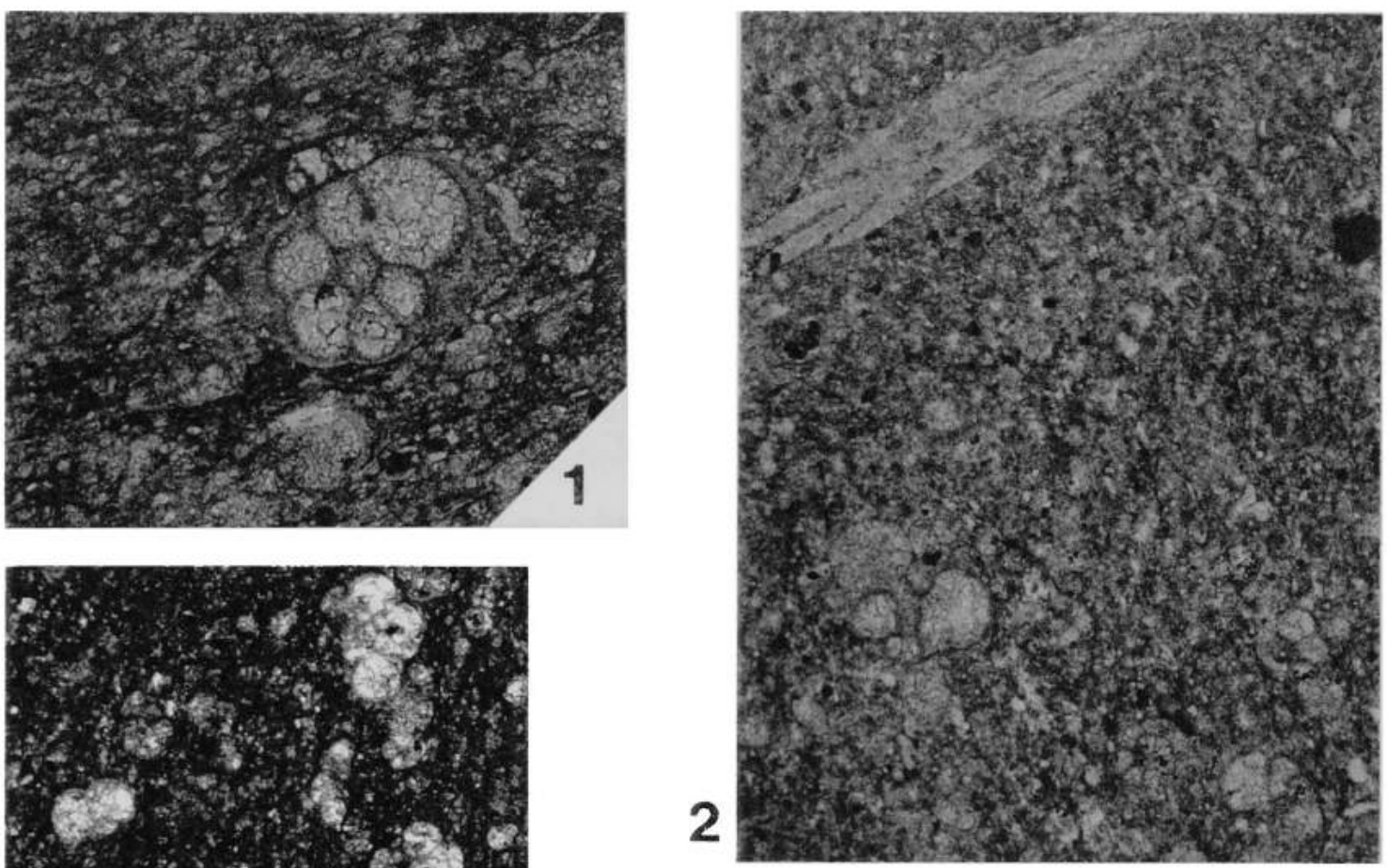
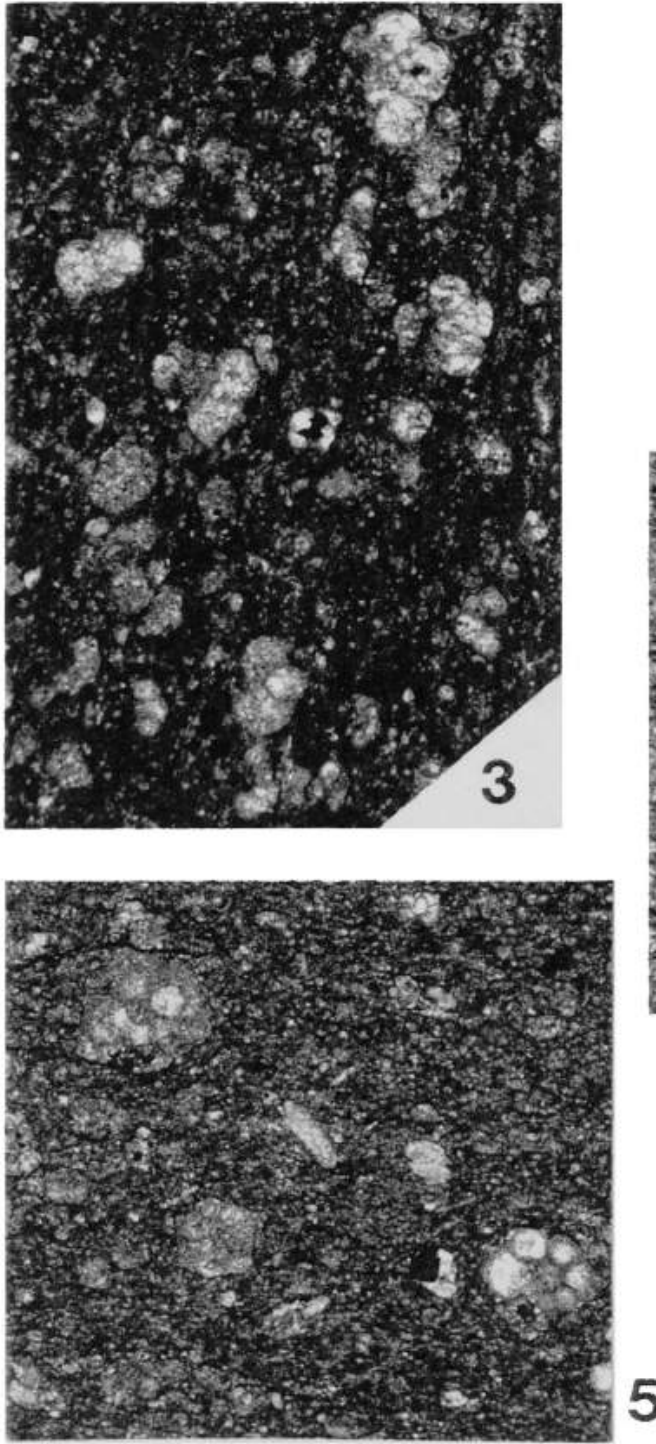

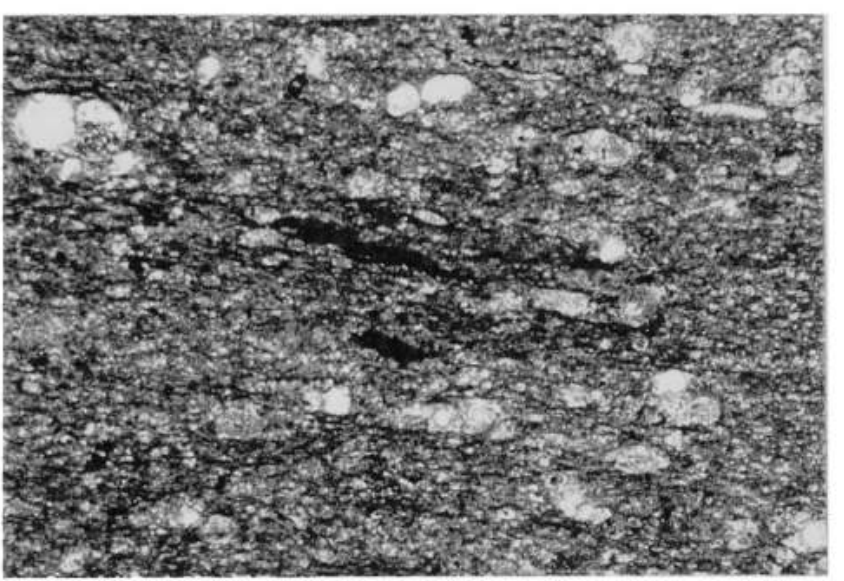

4

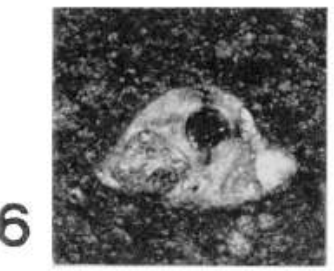

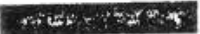


Figure 1. Biocalcilutite with planktonic foraminifera, mollusk fragments, and terrigenous materials. Note the apparent high concentration of organic matter. Sample LB G-26. Scale Bar $=200$ microns.

Figure 2. Biocalcilutite with planktonic foraminifera, mollusk fragments, and terrigenous materials. Note the apparent high concentration of organic matter. Sample LB G-26. Scale Bar $=400$ microns.

Figure 3. Biocalcilutite with recrystallized planktonic foraminifera and echinoid spines. Note the abundant terrigenous materials. Sample LB G -28 . Scale Bar $=200$ microns.

Figure 4. Biocalcilutite with planktonic foraminifera and terrigenous materials. Note the apparent high concentration of organic matter.

Sample LB 1-3b. Scale Bar $=200$ microns.

Figure 5. Benthonic foraminifera (Lagenid?).

Sample LB $1-4 \mathrm{c}$. Scale Bar $=200$ microns. 

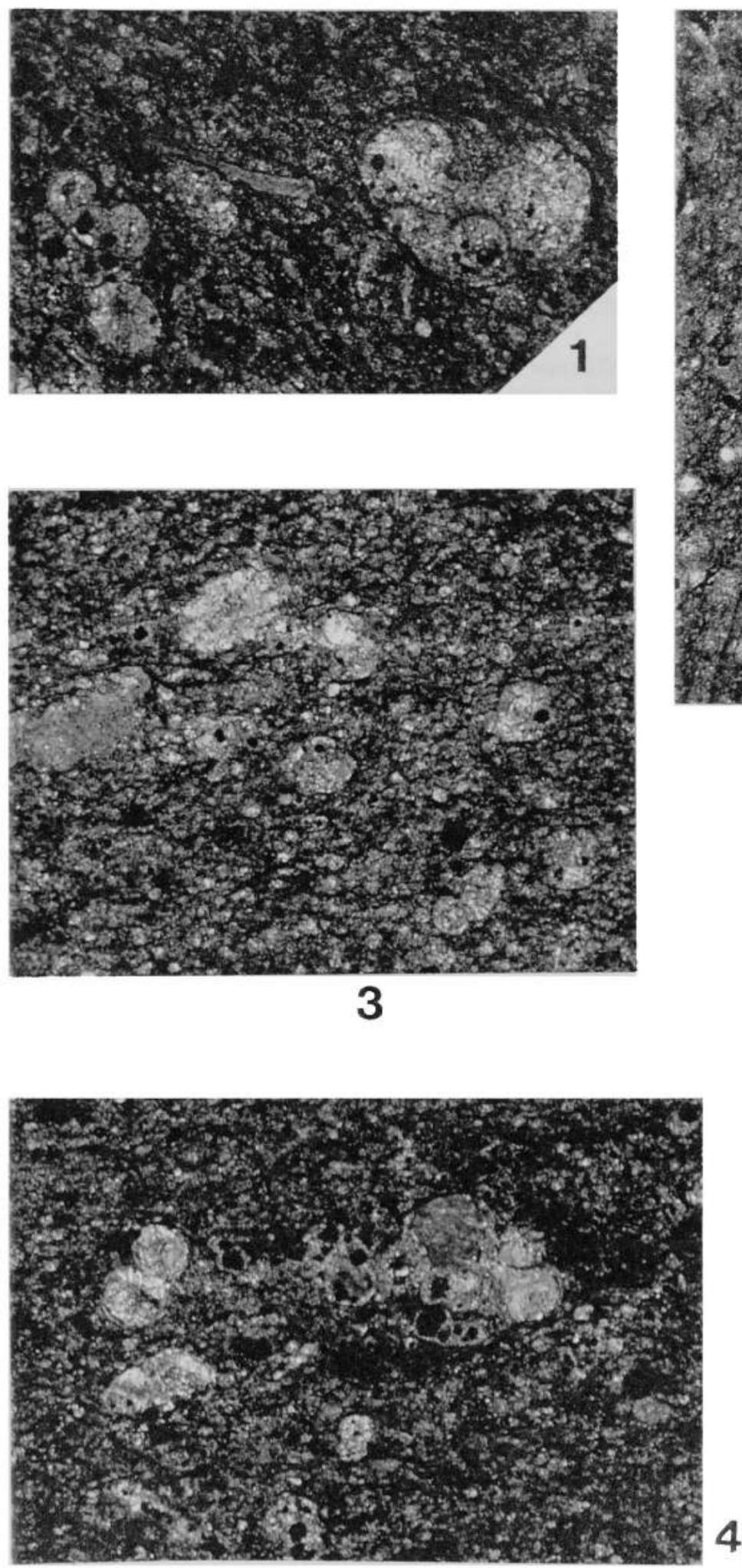
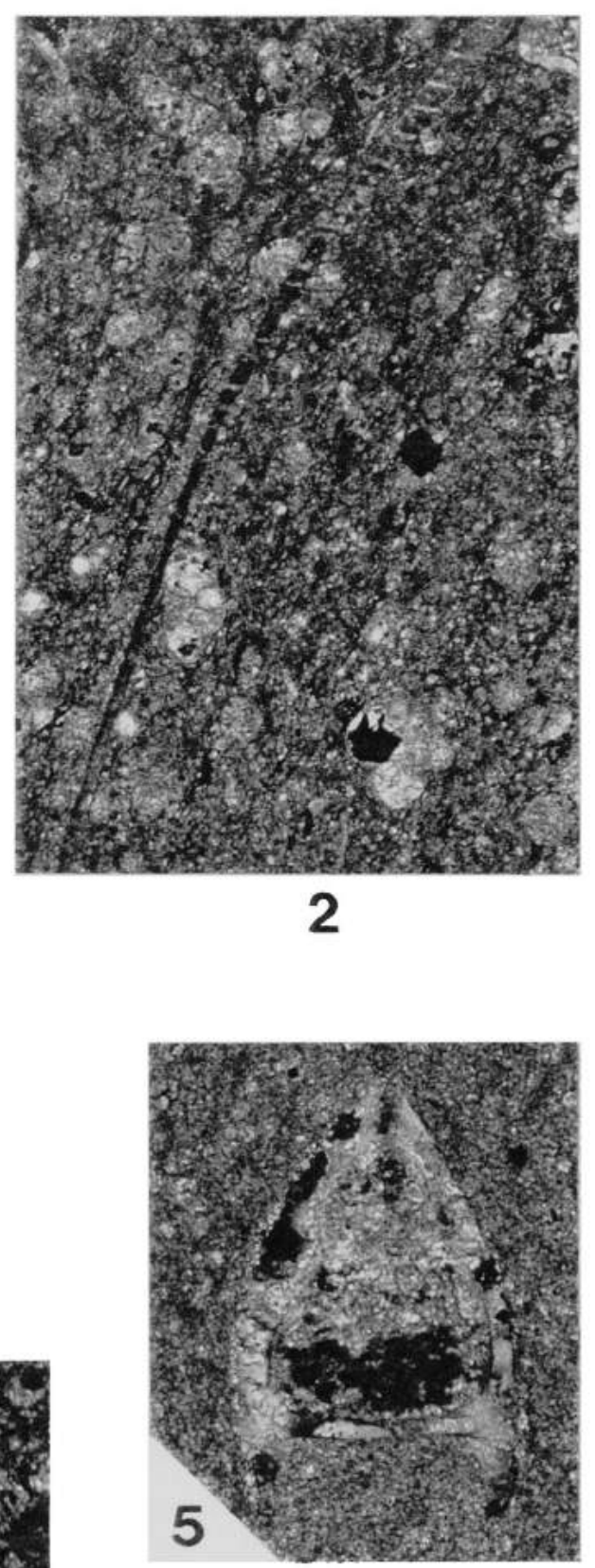

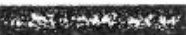


Figure 1. Planktonic foraminifera. Sample LB 1-17. Scale Bar $=200$ microns.

Figure 2. Belemnite rostrum. Sample LB 1-19. Scale Bar $=2000$ microns

Figure 3. Belemnite rostrum. Sample LB I-20a. Scale Bar $=2000$ microns

Figure 4. Biocalcilutite with planktonic foraminifera, recrystallized radiolaria, and ostracod fragments. Note the apparent high concentration of organic matter. Sample LB I-20a. Scale Bar $=200$ microns.

Figure 5. Biocalcilutite with planktonic foraminifera. Sample LB I-20b. Scale Bar $=400$ microns.

Figure 6. Belemnite rostrum. Sample LB I-20b. Scale Bar $=2000$ microns

Figure 7. Belemnite rostrum. Sample LB I-21a. Scale Bar $=2000$ microns

Figure 8. Lenticulinid (?) benthonic foraminifera.

Sample LB I-21b. Scale Bar $=200$ microns.

Figure 9. Planktonic foraminifera. Sample LB I-21c. Scale Bar $=200$ microns.

Figure 10. Biocalcilutite with planktonic foraminifera and terrigenous materials. Sample LB 1-23. Scale Bar $=400$ microns.

Figure 11. Echinoid spine and mollusk fragment.

Sample LB I-30. Scale Bar $=400$ microns. 
PLATE 44

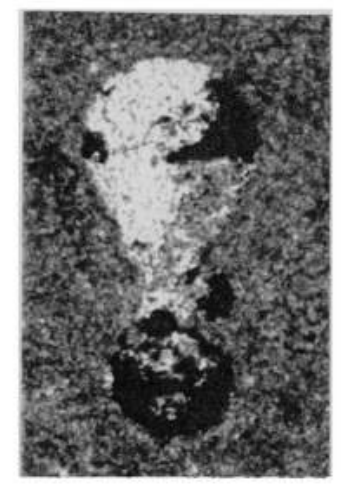

1

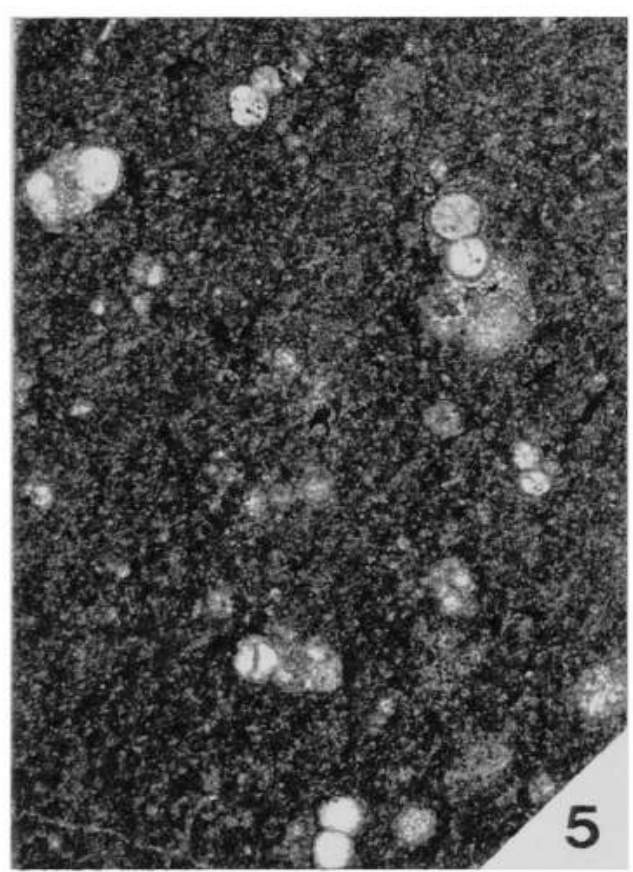

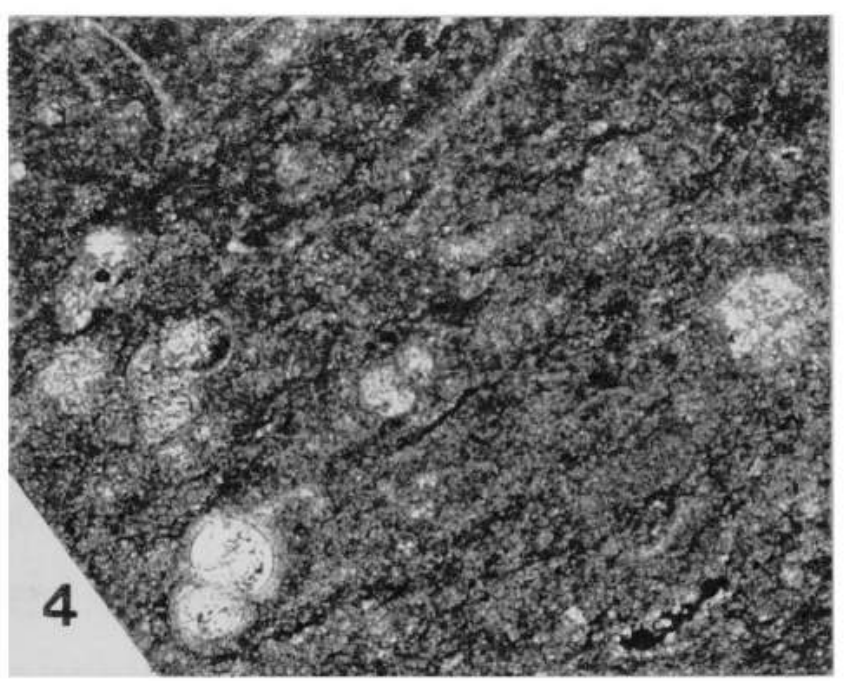

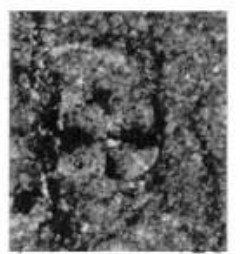

6
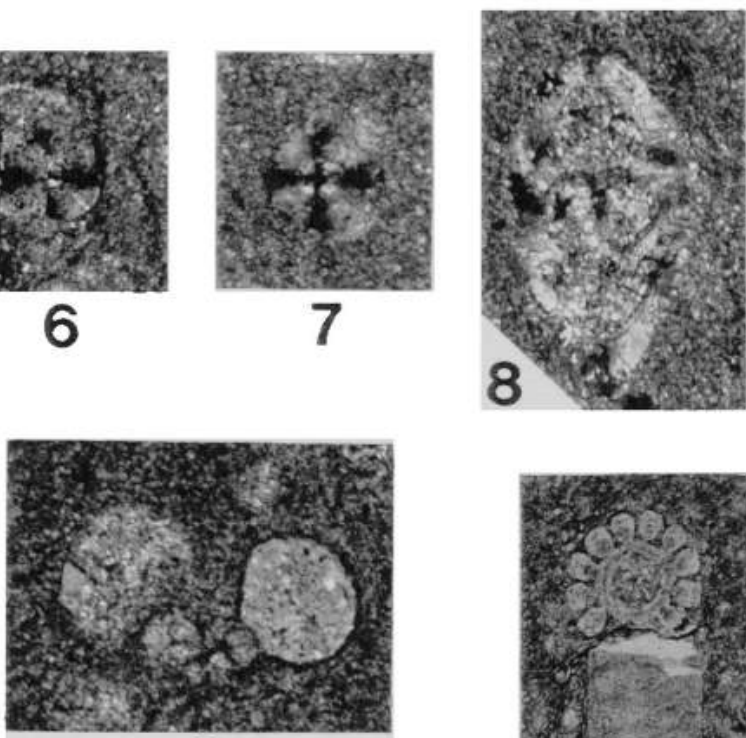

9
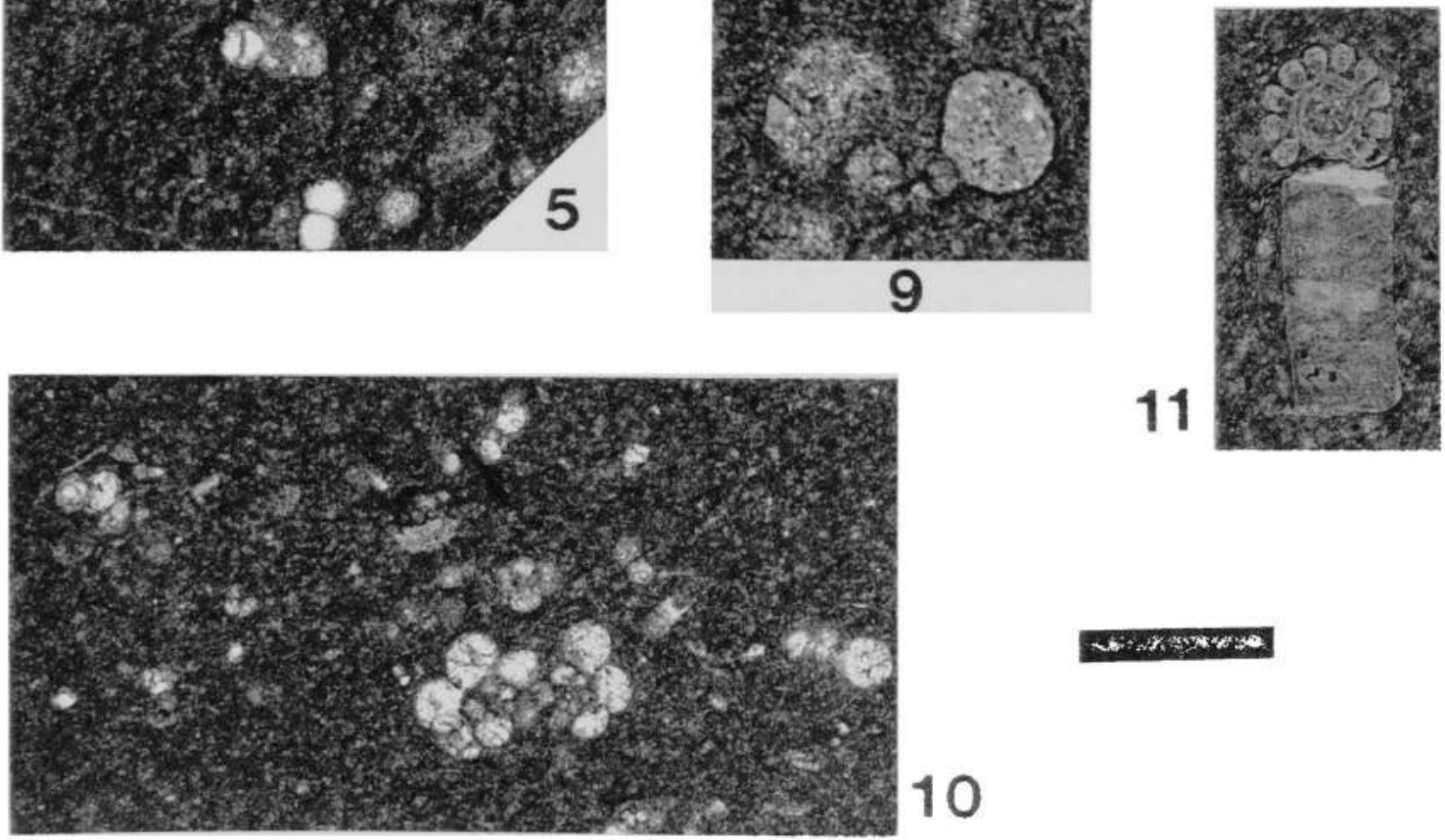

10 


\section{PLATE 45. La Peña Formation, La Boca Canyon}

Figure 1. Biocalcilutite with planktonic foraminifera, mollusk and ostracod fragments.

Note the high concentration of terrigenous materials.

Sample LB I-30. Scale Bar $=400$ microns.

Figure 2. Biocalcilutite with planktonic foraminifera and echinoid spines.

Sample LB I-41. Scale Bar $=400$ microns.

Figure 3. Echinoid spine. Sample LB I-46. Scale Bar $=400$ microns.

Figure 4. Planktonic foraminifera. Sample LB I-50. Scale Bar $=400$ microns.

Figure 5. Planktonic foraminifera. Sample LB 1-52a. Scale Bar $=200$ microns.

Figure 6. Echinoid spine. Sample LB I-52b. Scale Bar $=200$ microns.

Figure 7. Biocalcilutite with planktonic foraminifera, ostracod fragments, and terrigenous materials. Sample LB K-1. Scale Bar $=400$ microns.

Figure 8. Ostracod. Sample LB K-3. Scale Bar $=400$ microns.

Figure 9. Planktonic foraminifera. Sample LB K-7. Scale Bar $=200$ microns.

Figure 10. Benthonic foraminifera (Lagenid?). Sample LB K-7. Scale Bar $=200$ microns. 
PLATE 45

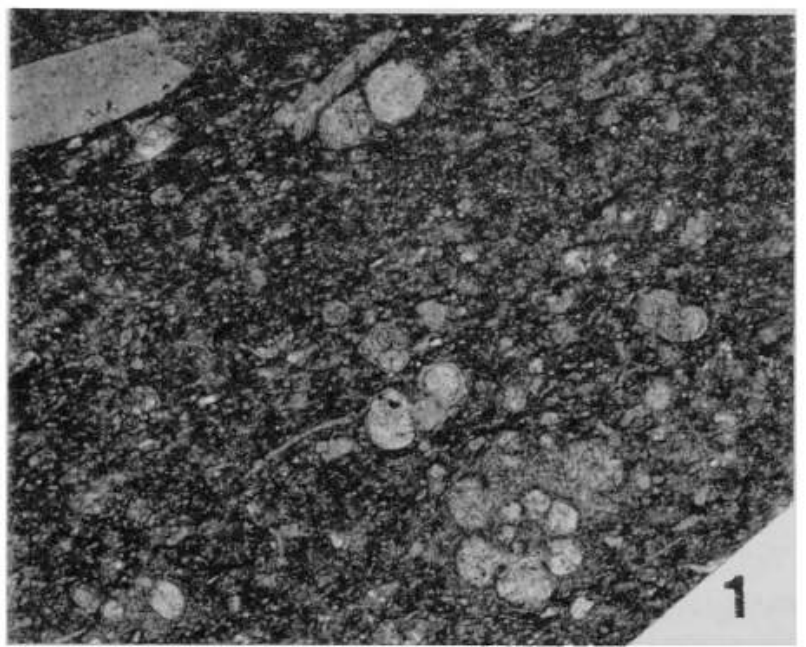

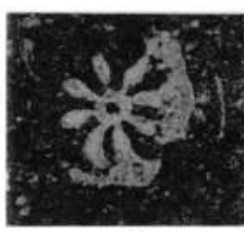

3
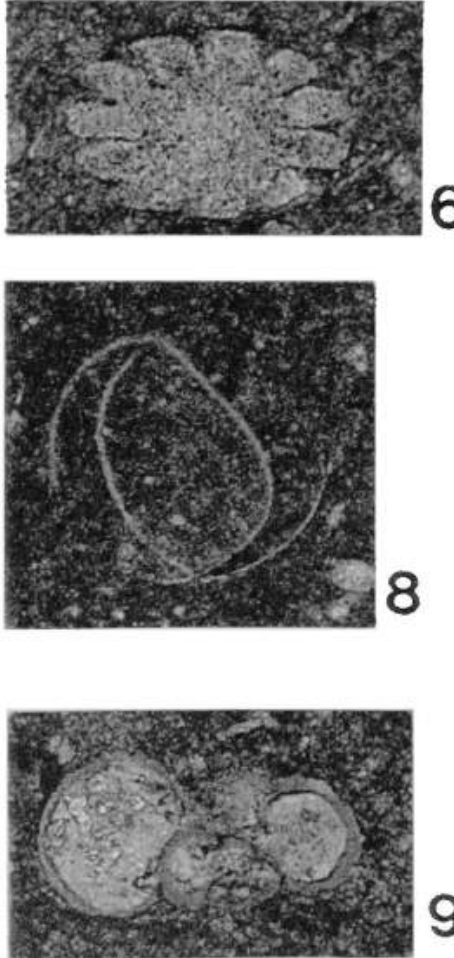

910

8

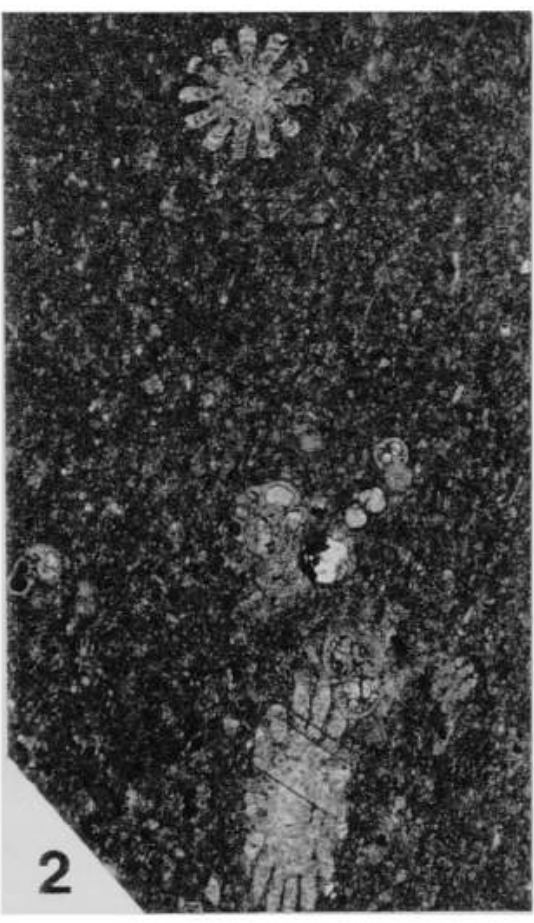

5
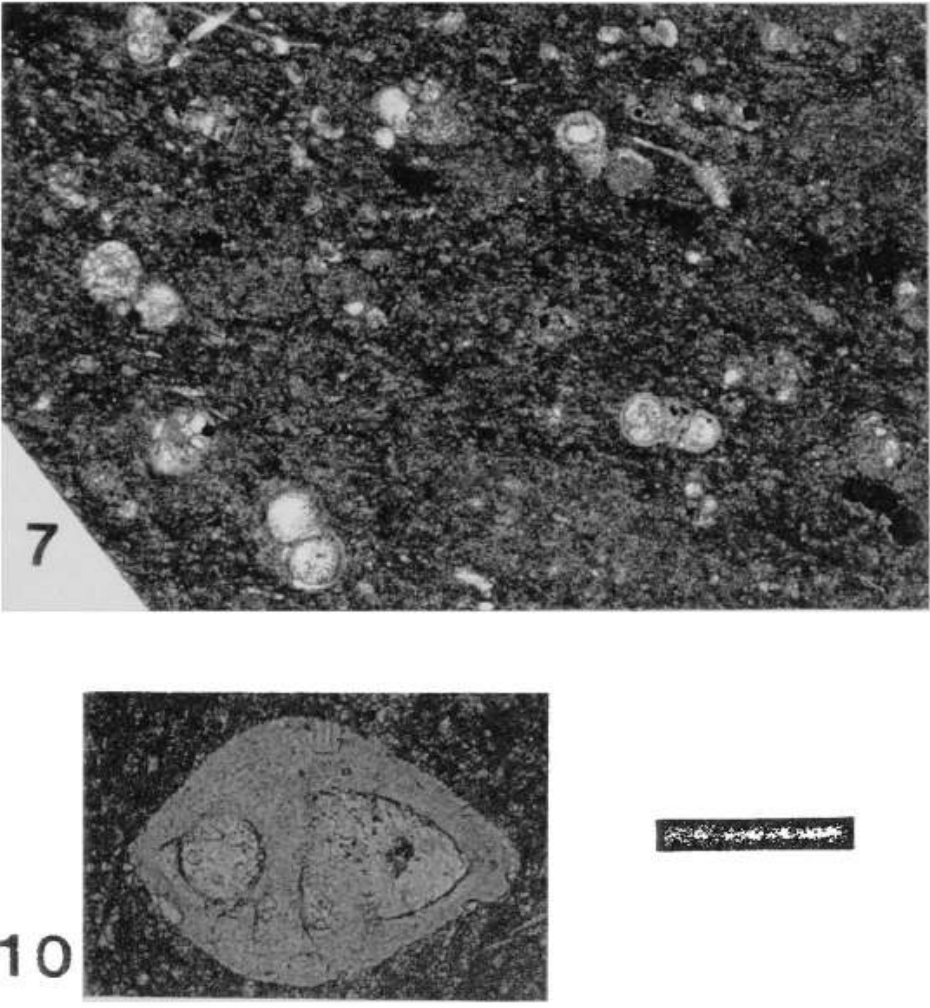

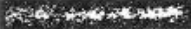




\section{PLATE 46. La Peña Formation, La Boca Canyon}

Figure 1. Planktonic foraminifera. Sample LB K-10. Scale Bar $=200$ microns.

Figure 2. Echinoid spine. Sample LB K $\mu 10$. Scale Bar $=200$ microns.

Figure 3. Biocalcilutite with planktonic foraminifera, lenticulinid benthonic foraminifera, mollusk, echinoid, and ostracod fragments, calcisphers, and terrigenous materials. Sample LB K-12. Scale Bar $=400$ microns.

Figure 4. Biocalcilutite with planktonic foraminifera, mollusk and echinoid fragments, and terrigenous materials. Large elongated bioclast seems to be a longitudinal section of a crinoid stem?. Sample LB M-a. Scale Bar $=400$ microns.

Figure 5. Longitudinal section of a crinoid stem?

Note the high concentration of terrigenous materials.

Sample LB O. Scale Bar $=400$ microns.

Figure 6. Biocalcilutite with planktonic foraminifera and recrystallized radiolaria.

Note the apparent high concentration of organic matter.

Sample LB S-4. Scale Bar $=400$ microns. 
PLATE 46
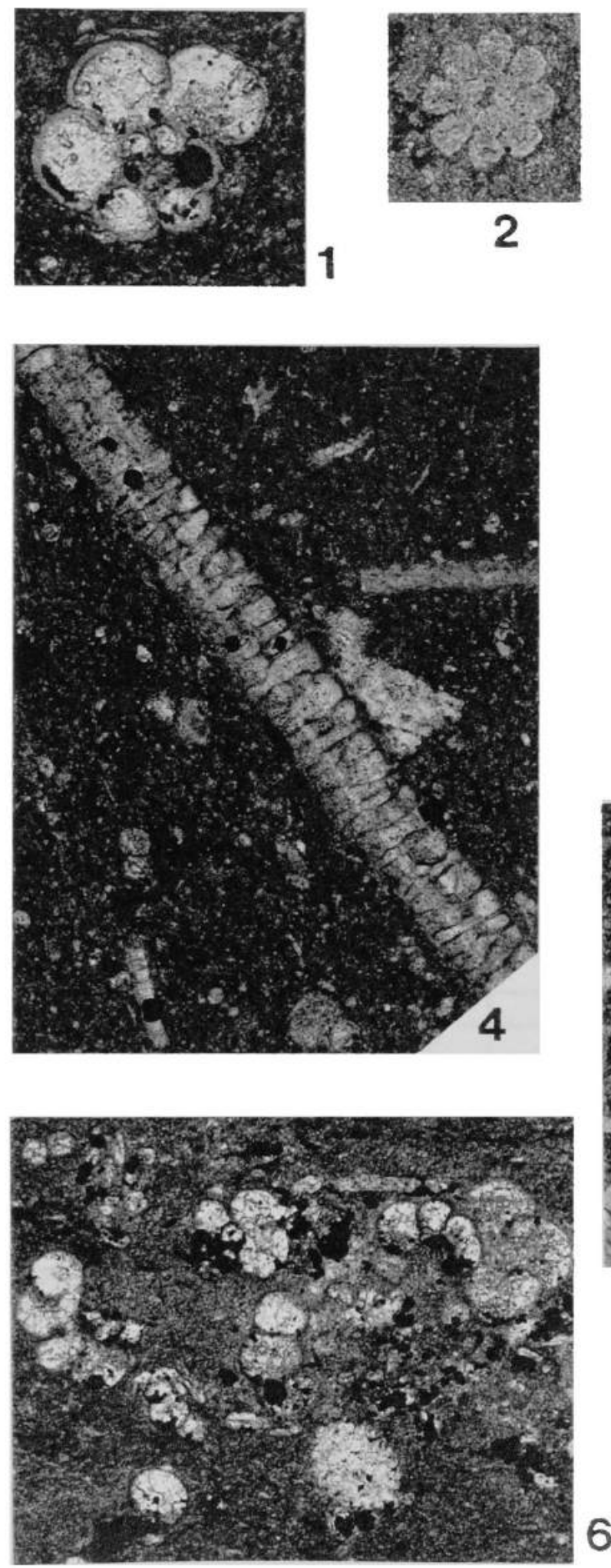
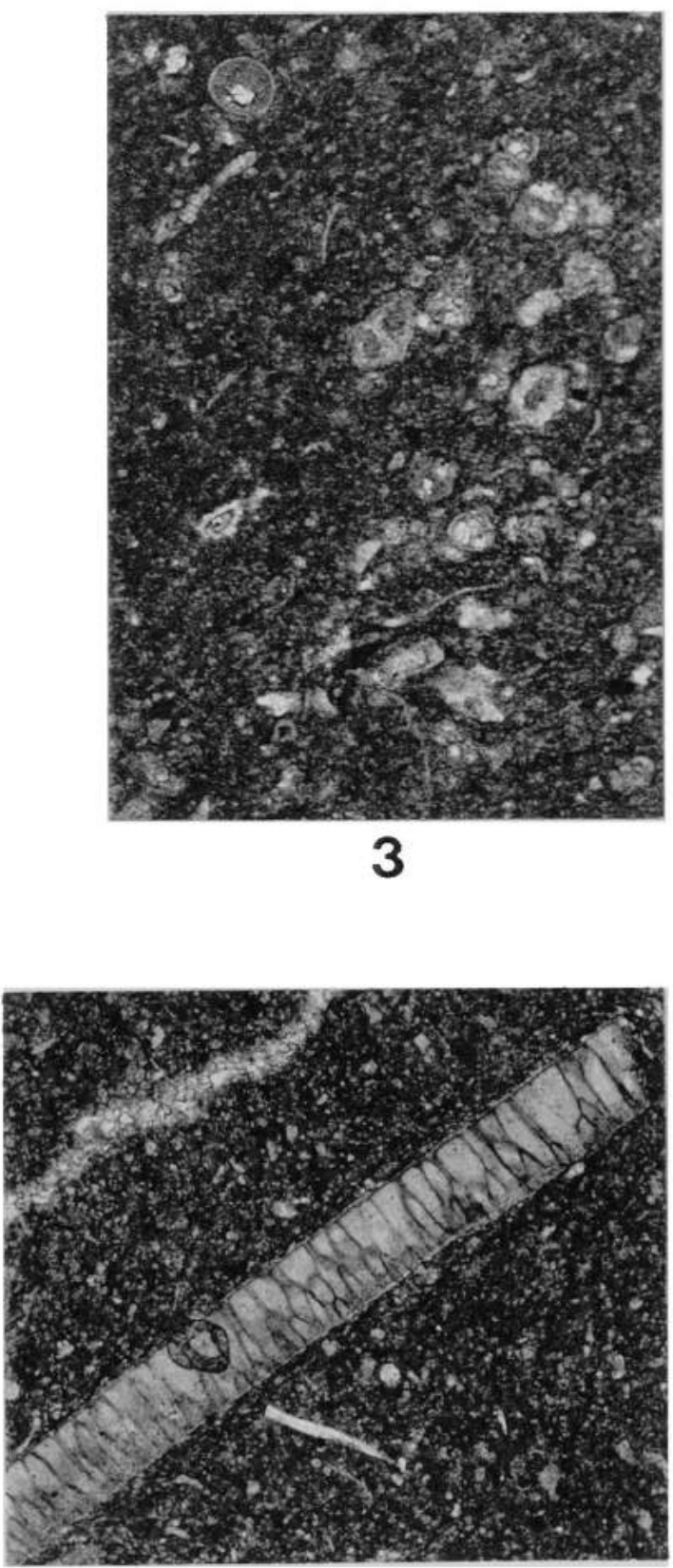

5

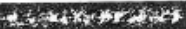




\section{Appendix 2}

Results of the Carbon/Carbonate Analyses of the rocks of the stratigraphic sequence at Francisco Zarco, Durango.

\begin{tabular}{|c|c|c|c|c|c|c|}
\hline SAMPLE & TOC $(\%)$ & TC $(\%)$ & & SAMPLE & TOC $(\%)$ & TIC $(\%)$ \\
& & & & & & \\
\hline PFZ-29a & 2.30 & 97.70 & & PFZ-46a & 0.62 & 99.38 \\
\hline PFZ-29b & 5.15 & 94.85 & & PFZ-46b & 0.82 & 97.24 \\
\hline PFZ-30a & 4.76 & 83.27 & & PFZ-46c & 1.51 & 98.49 \\
\hline PFZ-30b & 2.06 & 97.94 & & PFZ-47a & 1.10 & 96.30 \\
\hline PFZ-30c & 1.86 & 97.36 & & PFZ-47b & 0.83 & 93.70 \\
\hline PFZ-31 & 1.88 & 95.62 & & PFZ-48 & 0.60 & 96.14 \\
\hline PFZ-32a & 4.31 & 95.69 & & PFZ-49 & 0.57 & 97.13 \\
\hline PFZ-32b & 3.37 & 96.63 & & PFZ-50a & 0.68 & 99.32 \\
\hline PFZ-33 & 1.87 & 98.13 & & PFZ-50b & 0.91 & 98.07 \\
\hline PFZ-34a & 1.40 & 98.60 & & PFZ-51a & 0.63 & 99.37 \\
\hline PFZ-34b & 3.24 & 96.76 & & PFZ-51b & 0.60 & 99.40 \\
\hline PFZ-34c & 1.90 & 98.10 & & PFZ-52a & 0.66 & 99.34 \\
\hline PFZ-34d & 4.61 & 95.38 & & PFZ-52b & 0.51 & 99.49 \\
\hline PFZ-35 & 3.24 & 87.11 & & PFZ-52c & 0.66 & 99.34 \\
\hline PFZ-36a & 1.75 & 98.11 & & PFZ-53 & 0.93 & 98.77 \\
\hline PFZ-36b & 2.06 & 97.94 & & PFZ-54a & 0.84 & 99.16 \\
\hline PFZ-37a & 3.13 & 96.50 & & PFZ-54b & 0.88 & 99.12 \\
\hline PFZ-37b & 4.10 & 94.57 & & PFZ-55a & 0.73 & 99.27 \\
\hline PFZ-38a & 2.51 & 86.78 & & PFZ-55b & 2.85 & 97.15 \\
\hline PFZ-38b & 1.55 & 98.45 & & PFZ-55c & 0.87 & 99.13 \\
\hline PFZ-39 & 1.27 & 98.15 & & PFZ-56 & 0.78 & 99.22 \\
\hline PFZ-40a & 1.33 & 98.67 & & PFZ-57a & 0.68 & 99.32 \\
\hline PFZ-40b & 1.62 & 97.96 & & PFZ-57b & 2.81 & 97.19 \\
\hline PFZ-41 & 1.22 & 98.13 & & PFZ-57c & 0.84 & 99.16 \\
\hline PFZ-42 & 1.13 & 98.00 & & PFZ-58a & 4.58 & 93.95 \\
\hline PFZ-43a & 1.96 & 98.87 & & PFZ-58b & 0.58 & 99.35 \\
\hline PFZ-43b & 1.92 & 97.68 & & PFZ-58c & 0.96 & 98.81 \\
\hline PFZ-44a & 1.35 & 98.36 & & PFZ-59a & 0.63 & 99.36 \\
\hline PFZ-44b & 0.52 & 99.48 & & PFZ-59b & 6.23 & 93.77 \\
\hline PFZ-44c & 0.55 & 97.71 & & PFZ-59c & 0.58 & 99.42 \\
\hline PFZ-45a & 0.54 & 99.46 & & PFZ-59d & 0.96 & 97.73 \\
\hline PFZ-45b & 0.67 & 99.33 & & PFZ-59e & 0.13 & 99.87 \\
\hline PFZ-45c & 0.66 & 99.34 & & PFZ-60 & 1.32 & 96.81 \\
\hline & & & & & & \\
\hline
\end{tabular}




\begin{tabular}{|c|c|c|c|c|c|}
\hline SAMPLE & $\mathrm{TOC}(\%)$ & $\mathrm{TIC}(\%)$ & SAMPLE & TOC $(\%)$ & TIC (\%) \\
\hline PFZ-6la & 0.86 & 94.50 & PFZ-99c & 3.04 & 84.39 \\
\hline PFZ-61b & 6.37 & 6.01 & $\mathrm{PF}-100$ & 2.14 & 92.86 \\
\hline PFZ-61c & 3.24 & 95.30 & PFZ-101 & 0.03 & 45.84 \\
\hline PFZ-62 & 5.60 & 16.20 & PFZ-102 & 0.08 & 90.69 \\
\hline PFZ-63 & 4.57 & 92.95 & PFZ-103 & 0.37 & 86.49 \\
\hline PFZ 64 & 1.42 & 23.08 & PFZ-104 & 0.01 & 91.35 \\
\hline PFZ 65 & 6.20 & 92.95 & PFZ-105 & 0.10 & 0.18 \\
\hline PFZ-66 & 8.72 & 59.73 & PFZ-106 & 0.55 & 91.37 \\
\hline PFZ-67 & 4.26 & 92.39 & PFZ-107 & 0.53 & 69.23 \\
\hline PFZ-68 & 1.94 & 77.59 & PFZ-108 & 0.18 & 95.48 \\
\hline PFZ 69 & 2.44 & 94.88 & PFZ -109 & 0.13 & 94.99 \\
\hline PFZ-70 & 5.16 & 37.20 & $P F-110$ & 0.66 & 94.96 \\
\hline PFZ-7I & 2.84 & 93.58 & $\mathrm{PF},-111$ & 0.24 & 95.42 \\
\hline PFZ-72 & 7.22 & 50.90 & PFZ- 112 & 0.12 & 93.58 \\
\hline PFZ-73 & 5.04 & 93.95 & PFZ-113a & 0.17 & 89.20 \\
\hline PFZ-74 & 1.74 & 83.29 & PFZ-113b & 0.96 & 95.50 \\
\hline PFZ-75 & 5.08 & 26.28 & PFZ- $113 \mathrm{c}$ & 0.25 & 81.43 \\
\hline PFZ-76 & 2.70 & 95.94 & PFZ-114 & 0.93 & 95.00 \\
\hline PFZ-77 & 0.33 & 71.38 & PFZ-115 & 0.43 & 97.83 \\
\hline PFZ-78 & 0.15 & 95.65 & $\mathrm{PFZ}-116 \mathrm{a}$ & 1.26 & 91.98 \\
\hline PFZ-79 & 0.30 & 67.08 & PFZ-116b & 0.16 & 78,12 \\
\hline PFZ-80a & 3.00 & 84.21 & PFZ-117 & 0.02 & 91.35 \\
\hline PFZ-80D & 0.61 & 43.54 & PFZ-118 & 0.13 & 93.08 \\
\hline PFZ-80c & 2.43 & 91.94 & PFZ-119 & 0.17 & 55.98 \\
\hline PFZ-8I & 0.61 & 72.10 & PFZ-120 & 0.28 & 92.26 \\
\hline PFZ-82 & 3.72 & 93.92 & $\mathrm{PFZ}-121$ & 0.15 & 22.05 \\
\hline PFZ-83 & 1.95 & 47.97 & PFZ-122 & 0.36 & 87.76 \\
\hline PFZ-84 & 0.46 & 99.54 & PFZ-123 & 0.31 & 0.34 \\
\hline PFZ -85 & 2.80 & 97.20 & PFZ-124a & 0.42 & 73.84 \\
\hline PFZ.86 & 0.22 & 85.06 & PFZ-124b & 0.21 & 86.88 \\
\hline PFZ-87 & 1.84 & 87.27 & PFZ-126 & 0.06 & 80.50 \\
\hline PFZ-88 & 1.90 & 98.10 & PFZ-126 & 0.02 & 10.47 \\
\hline PFZ-89 & 0.06 & 73.34 & PFZ-127a & 0.71 & 90.73 \\
\hline PFZ-90a & 5.24 & 90.92 & PFZ-127b & 0.41 & 93.22 \\
\hline PFZ-90b & 5.50 & 56.81 & $P F Z+128$ & 0.29 & 89.36 \\
\hline PFZ-9I & 1.03 & 84.29 & $P F Z=129$ & 0.77 & 16.41 \\
\hline PFZ-92 & 1.02 & 75.65 & PFZ-130 & 0.03 & 92.54 \\
\hline PFZ-93 & 1.94 & 94.08 & PFZ-131 & 1.43 & 89.75 \\
\hline PFZ-94 & 2.03 & 47.58 & PFZ-132 & 0.57 & 90.33 \\
\hline PFZ-95 & 3.23 & 91.33 & PFZ-133 & 1.35 & 18.56 \\
\hline PFL-96 & 2.28 & 97.72 & PFZ-134 & 1.68 & 94.76 \\
\hline PFZ 97 & 7.40 & 86.18 & PFZ-135 & 1.21 & 96.12 \\
\hline PFZ-98 & 5.92 & 65.05 & PFZ-136a & 1.12 & 93.77 \\
\hline PFZ-99a & 3.14 & 95.86 & $\mathrm{PHZ}=136 \mathrm{~b}$ & 1.23 & 83.12 \\
\hline$P F Z-99 b$ & 3.05 & 24.31 & $P F Z-136 c$ & 10.48 & 80.72 \\
\hline
\end{tabular}




\begin{tabular}{|c|c|c|c|c|c|}
\hline SAMPLE & $\mathrm{TOC}(\%)$ & $\mathrm{TIC}(\%)$ & SAMPLE & $\operatorname{TOC}(\%)$ & $\mathrm{TIC}(\%)$ \\
\hline $\mathrm{PFZ}-137$ & 18.39 & 73.44 & PFZ-169a & 4.72 & 89.53 \\
\hline PFZ-138 & 16.50 & 75.42 & $\mathrm{PF} Z-169 \mathrm{~b}$ & 4.16 & 92.20 \\
\hline PFZ-139 & 16.99 & 76.13 & PFZ-170a & 9.75 & 70.81 \\
\hline PFZ-140a & 0.46 & 89.71 & PFZ $170 b$ & 6.10 & 93.71 \\
\hline PFZ-140b & 0.34 & 54.37 & PEZ-171a & 2.64 & 93.23 \\
\hline PFZ-14I & 11.28 & 81.84 & PFZ-1716 & 3.89 & 86.80 \\
\hline PFZ-142a & 15.03 & 79.02 & PFZ-172 & 6.61 & 91.33 \\
\hline PFZ-142b & 12.65 & 78.48 & PFZ-173a & 4.54 & 82.94 \\
\hline PFZ-143a & 13.43 & 77.35 & PFZ-173b & 4.06 & 90.18 \\
\hline PFZ-143b & 15.81 & 80.61 & PFZ-174 & 10.61 & 73.38 \\
\hline PFZ-143c & 1.44 & 93.60 & PFZ-175 & 3.88 & 93.39 \\
\hline PFZ $144 a$ & 3.10 & 86.64 & PFZ -176 & 3.40 & 79.80 \\
\hline PFZ-144b & 14.57 & 80.39 & PFZ 177 & 2.95 & 97.05 \\
\hline PFZ-145 & 12.64 & 81.40 & PFZ-178 & 2.75 & 89.32 \\
\hline PFZ-146 & 0.16 & 50.50 & PFZ-179 & 3.38 & 95.54 \\
\hline PFZ-147 & 14.09 & 80.09 & PFZ-180 & 5.48 & 91.33 \\
\hline PFZ-148 & 12.28 & 79.83 & PFZ-181 & 2.14 & 94.48 \\
\hline PFZ-149 & 12.57 & 81.38 & PFZ-182 & 2.87 & 97.13 \\
\hline PFZ-150 & 10.34 & 84.67 & PFZ-183a & 9.46 & 71.66 \\
\hline PFZ-151 & 11.54 & 83.15 & PFZ-183b & 1.58 & 92.63 \\
\hline PFZ"152 & 0.20 & 63.02 & PFZ 184a & 3.19 & 91.44 \\
\hline PFZ-153a & 0.22 & 43.25 & $\mathrm{PFZ}-184 \mathrm{~b}$ & 2.25 & 92.09 \\
\hline PFZ-153b & 9.70 & 84.58 & PFZ 188 & 2.99 & 96.79 \\
\hline PFZ-154 & 5.04 & 82.32 & PFZ-190a & 3.04 & 86.38 \\
\hline $\mathrm{PFZ}-155$ & 11.88 & 84.13 & PFZ-190b & 4.55 & 92.28 \\
\hline PFZ-156 & 0.16 & 74.57 & PFZ-190c & 2.59 & 85.76 \\
\hline PFZ-157 & 9.57 & 85.01 & $\mathrm{PFZ}-190 \mathrm{~d}$ & 6.10 & 84.26 \\
\hline PFZ-158 & 0.17 & 52.21 & PFZ-191 & 5.68 & 91.59 \\
\hline PFZ-159 & 0.28 & 93.95 & PFZ 192 & 1.72 & 92.19 \\
\hline PFZ-160 & 0.85 & 93.51 & PFZ 193 & 3.23 & 94.37 \\
\hline PFZ-161 & 1.02 & 57.67 & PFZ 194 & 3.17 & 94.87 \\
\hline PFZ-162a & 2.45 & 90.22 & PFZ 195 & 7.09 & 91.57 \\
\hline PFZ-162b & 15.21 & 84.79 & PFZ 196 & 4.99 & 78.98 \\
\hline $\mathrm{PFZ}-162 \mathrm{c}$ & 4.55 & 93.44 & PFZ-197 & 4.34 & 88.90 \\
\hline PFZ-163 & 1.58 & 71.18 & PFZ-198 & 15.13 & 84.87 \\
\hline PFZ-164 & 2.87 & 90.92 & PFZ-199 & 4.53 & 47.09 \\
\hline PFZ-165 & 2.43 & 57.37 & PFZ-200 & 4.11 & 95.89 \\
\hline PFZ 166 & 5.50 & 85.44 & PFZ-201 & 4.65 & 91.00 \\
\hline $\mathrm{PFZ}-167$ & 3.54 & 5.02 & $\mathrm{PFZ}-202$ & 4.30 & 85.25 \\
\hline PFZ-168a & 2.20 & 96.76 & PFZ-203 & 8.28 & 91.42 \\
\hline PFZ-168b & 6.00 & $90 . \overline{01}$ & & & \\
\hline
\end{tabular}




\section{Appendix 3}

Results of the Carbon/Carbonate Analyses of the rocks of the stratigraphic sequence at La Boca Canyon, Nuevo Leon.

\begin{tabular}{|c|c|c|c|c|c|c|}
\hline SAMPLE & TOC $(\%)$ & TIC $(\%)$ & & SAMPLE & TOC (\%) & TIC (\%) \\
\hline LBA-1 & 1.45 & 95.55 & & LB A-29 & 3.98 & 80.25 \\
\hline LBA-2 & 2.76 & 95.24 & & LB B-2 & 2.93 & 65.65 \\
\hline LBA-3a & 2.38 & 95.62 & & LB C-1 & 3.33 & 63.19 \\
\hline LBA-3b & 1.63 & 96.37 & & LB C-2 & 3.90 & 83.71 \\
\hline LBA-4a & 1.94 & 96.06 & & LB C-3 & 3.97 & 75.49 \\
\hline LBA-4b & 1.70 & 96.30 & & LB C-4 & 4.24 & 92.25 \\
\hline LBA-4c & 2.87 & 95.13 & & LB C-5 & 5.58 & 87.71 \\
\hline LBA-5 & 1.70 & 96.30 & & LB C-6 & 2.75 & 95.25 \\
\hline LBA-6a & 2.00 & 96.00 & & LB C-8 & 2.70 & 85.77 \\
\hline LBA-6b & 1.80 & 96.20 & & LB C-10 & 3.17 & 75.85 \\
\hline LBA-7 & 2.61 & 95.39 & & LB C-11a & 2.87 & 80.56 \\
\hline LBA-8 & 4.32 & 93.68 & & LB C-11b & 2.28 & 89.64 \\
\hline LBA-9 & 1.92 & 96.08 & & LB C-11c & 4.62 & 89.07 \\
\hline LBA-10a & 2.47 & 95.53 & & LB D-2 & 4.00 & 89.01 \\
\hline LBA-10b & 3.75 & 94.25 & & LB D-4 & 4.52 & 72.03 \\
\hline LBA-10c & 2.00 & 96.70 & & LB E-1 & 4.58 & 73.61 \\
\hline LBA-11 & 2.50 & 9.43 & & LB E-2 & 3.81 & 84.25 \\
\hline LBA-12 & 2.50 & 96.75 & & LB E-3a & 4.98 & 73.94 \\
\hline LBA-13 & 2.43 & 93.71 & & LB E-3b & 6.26 & 84.91 \\
\hline LBA-14 & 1.60 & 97.75 & & LB E-4 & 3.45 & 74.85 \\
\hline LBA-15 & 2.55 & 95.45 & & LB E-6 & 3.72 & 83.49 \\
\hline LBA-16 & 2.36 & 97.01 & & LBE-7a & 4.42 & 81.90 \\
\hline LBA-17 & 2.39 & 60.25 & & LB E-7b & 5.42 & 84.85 \\
\hline LBA-18 & 3.52 & 84.78 & & LBE-8a & 4.04 & 83.20 \\
\hline LBA-19 & 1.88 & 69.17 & & LB E-8b & 3.86 & 91.39 \\
\hline LBA-20 & 2.16 & 86.49 & & LB E-9 & 3.11 & 81.66 \\
\hline LBA-21 & 3.46 & 75.84 & & LB E-10 & 4.81 & 83.44 \\
\hline LBA-22 & 2.80 & 90.18 & & LB G-1 & 2.36 & 89.64 \\
\hline LBA-23 & 3.00 & 79.60 & & LB G-2 & 3.74 & 83.67 \\
\hline LBA-24 & 3.77 & 86.58 & & LB G-3a & 7.21 & 85.28 \\
\hline LBA-25 & 2.24 & 59.97 & & LB G-3b & 3.85 & 90.48 \\
\hline LBA-26 & 2.86 & 63.08 & & LB G-3c & 4.53 & 93.50 \\
\hline LBA-27 & 3.95 & 77.05 & & LB G-4 & 3.81 & 89.02 \\
\hline LBA-28 & 3.71 & 8.48 & & LB G-5 & 6.21 & 86.05 \\
\hline
\end{tabular}




\begin{tabular}{|c|c|c|c|c|c|}
\hline SAMPLE & $\mathrm{TOC}(\%)$ & $\mathrm{TIC}(\%)$ & SAMPLE & $\mathrm{TOC}(\%)$ & $\mathrm{TIC}(\%)$ \\
\hline LB G-6 & 6.14 & 62.02 & LB I-6 & 2.54 & 89.09 \\
\hline $\mathrm{LB} \mathrm{G}+7$ & 5.15 & 85.43 & LB I-7 & 5.98 & 80.68 \\
\hline LB G-9a & 17.57 & 68.87 & LB I-9a & 7.15 & 73.45 \\
\hline LB G-9b & 5.21 & 82.78 & LB l-9b & 6.50 & 83.83 \\
\hline $\mathrm{LB} \mathrm{G}+10$ & 14.00 & 48.96 & LB Im $11 \mathrm{a}$ & 6.37 & 79.67 \\
\hline LB G-11 & 5.16 & 87.72 & LB I-11b & 7.28 & 83.74 \\
\hline $\mathrm{LB} \mathrm{G}-12 \mathrm{a}$ & 10.01 & 78.76 & LB I-12 & 2.73 & 91.15 \\
\hline $\mathrm{LB} \mathrm{G} 12 \mathrm{~b}$ & 6.54 & 85.93 & LB I-14 & 4.16 & 83.61 \\
\hline $\mathrm{LB} \mathrm{G} 13$ & 8.41 & 70.58 & LB I-16a & 1.43 & 80.55 \\
\hline $\mathrm{LB} \mathrm{G}-14$ & 5.00 & 84.20 & LB I-16b & 3.25 & 86.05 \\
\hline $\mathrm{LB} \mathrm{G+15}$ & 1.90 & 94.51 & LB $1-16 \mathrm{c}$ & 2.47 & 91.49 \\
\hline $\mathrm{LB} \mathrm{G-17}$ & 1.87 & 94.97 & LB I-17 & 2.60 & 93.75 \\
\hline LB G-19 & 1.22 & 92.04 & LB $1-18$ & 1.95 & 94.32 \\
\hline$\overline{L B ~ G-20 a}$ & 3.52 & 93.65 & LB I-19 & 2.34 & 93.48 \\
\hline LB G-20b & 12.21 & 85.14 & LB 1-20a & 3.77 & 91.02 \\
\hline LB G-21 & 4.43 & 93.30 & LB $l-20 \mathrm{~b}$ & 3.12 & 89.65 \\
\hline LB G-23a & 2.00 & 94.15 & LB I-21a & 3.77 & 87.18 \\
\hline $\mathrm{LB} \mathrm{G}-23 \mathrm{~b}$ & 3.80 & 92.82 & LB I-2lb & 3.80 & 91.84 \\
\hline LBB G-25 & 16.16 & 71.57 & $\mathrm{LB} /-2 \mathrm{lc}$ & 3.78 & 92.55 \\
\hline $\mathrm{LB}$ G-26 & 5.37 & 77.97 & LB I-22 & 1.05 & 96.06 \\
\hline $\mathrm{LB}$ G-27a & 5.75 & 58.96 & LB I-23 & 2.27 & 95.63 \\
\hline $\mathrm{LB} \mathrm{G}-27 \mathrm{~b}$ & 3.88 & 64.93 & LB 1-24 & 2.43 & 96.05 \\
\hline $\mathrm{LB} \mathrm{G-28}$ & 4.58 & 81.17 & LB I-25 & 2.35 & 95.93 \\
\hline LB G-29 & 4.58 & 81.17 & LB I-26 & 2.87 & 94.37 \\
\hline LB G-3I & 4.87 & 80.06 & LB $1+27$ & 2.26 & 95.07 \\
\hline LB G-32 & 3.98 & 90.08 & LB I-28 & 2.15 & 95.47 \\
\hline $\mathrm{LB} \mathrm{G}-33$ & 3.86 & 88.37 & $\mathrm{LBC}-30$ & 2.28 & 87.76 \\
\hline LB G-34a & 3.84 & 87.87 & LB I-32 & 2.36 & 89.10 \\
\hline LB G-34b & 2.58 & 90.65 & LB I-33 & 2.76 & 82.01 \\
\hline LB G-35 & 3.00 & 87.56 & LB I-34 & 3.10 & 88.34 \\
\hline LB G-36 & 5.13 & 92.28 & LB I-35 & 3.32 & 78.55 \\
\hline LB I-1 & 3.18 & 70.13 & LB l-37 & 3.08 & 81.02 \\
\hline LB [-2 & 3.29 & 81.05 & LB I-38 & 3.15 & 81.99 \\
\hline LB I-3a & 9.20 & 84.21 & LB $[40 \mathrm{a}$ & 4.05 & 84.46 \\
\hline LB I-3b & 4.83 & 72.12 & LB $[-40 \mathrm{~b}$ & 3.12 & 84.50 \\
\hline LB I $+4 a$ & 3.33 & 84.02 & LB I-4I & 3.26 & 78.97 \\
\hline LB I-4b & 2.80 & 84.66 & LB $1-42$ & 3.00 & 84.75 \\
\hline$\overline{L B} \mid-4 \mathrm{c}$ & 2.28 & 88.10 & LB I-43 & 2.96 & 82.15 \\
\hline LB I-5a & 4.36 & 82.31 & LB I-44 & 2.86 & 89.83 \\
\hline LB I-5b & 3.00 & 75.44 & LB $1-45$ & 3.00 & 84.26 \\
\hline LB $I-5 c$ & 4.72 & 80.40 & LB I-46 & 3.15 & 88.12 \\
\hline
\end{tabular}




\begin{tabular}{|c|c|c|c|c|c|c|}
\hline SAMPLE & TOC $(\%)$ & TIC $(\%)$ & & SAMPLE & TOC $(\%)$ & TIC (\%) \\
\hline LB I-48 & 3.02 & 92.97 & & LB K-9 & 17.00 & 79.76 \\
\hline LB I-49a & 2.92 & 92.66 & & LB K-10 & 18.60 & 80.23 \\
\hline LB I-49b & 3.32 & 92.53 & & LB K-12 & 18.00 & 80.32 \\
\hline LB I-50 & 3.16 & 91.22 & & LB K-13 & 17.13 & 81.55 \\
\hline LB 1-51 & 3.00 & 87.61 & & LB K-15 & 17.62 & 77.43 \\
\hline LB I-52a & 2.96 & 86.78 & & LB K-16 & 18.00 & 79.72 \\
\hline LB I-52b & 2.80 & 82.28 & & LB Ma & 10.76 & 88.71 \\
\hline LB I-54 & 3.12 & 91.60 & & LB Mb & 11.00 & 88.00 \\
\hline LB I-56 & 5.82 & 85.60 & & LBO & 12.15 & 87.46 \\
\hline LB I-58 & 6.12 & 76.95 & & LB Q & 13.86 & 85.14 \\
\hline LB I-60 & 8.16 & 85.99 & & LB S-1 & 3.06 & 95.94 \\
\hline LB K-1 & 10.75 & 85.46 & & LB S-3a & 2.82 & 96.18 \\
\hline LB K-2 & 14.20 & 82.23 & & LB S-3b & 3.60 & 95.40 \\
\hline LB K-3 & 13.12 & 84.09 & & LB S-4 & 2.92 & 96.08 \\
\hline LB K-4 & 17.00 & 80.44 & & LB S-5a & 3.43 & 95.57 \\
\hline LB K-5 & 19.46 & 78.04 & & LB S-5b & 2.18 & 96.82 \\
\hline LB K-7 & 18.12 & 78.29 & & LB S-6 & 2.28 & 96.72 \\
\hline
\end{tabular}




\section{Appendix 4}

\section{AMMONITES PLATES:}

The following section includes plates 47 through 59 , showing morphological characteristics of the ammonite species discussed in the Systematic Paleontology of the group.

(All figures at natural size) 


\section{PLATE 47}

Figure 1. Paracymatoceras milleri Humphrey. Specimen PFZ 0273. Side view.

La Peña Formation, stratigraphic level PFZ-93.

Presa Francisco Zarco, Durango.

Lower Aptian (Dufrenoyia justinae Zone). 


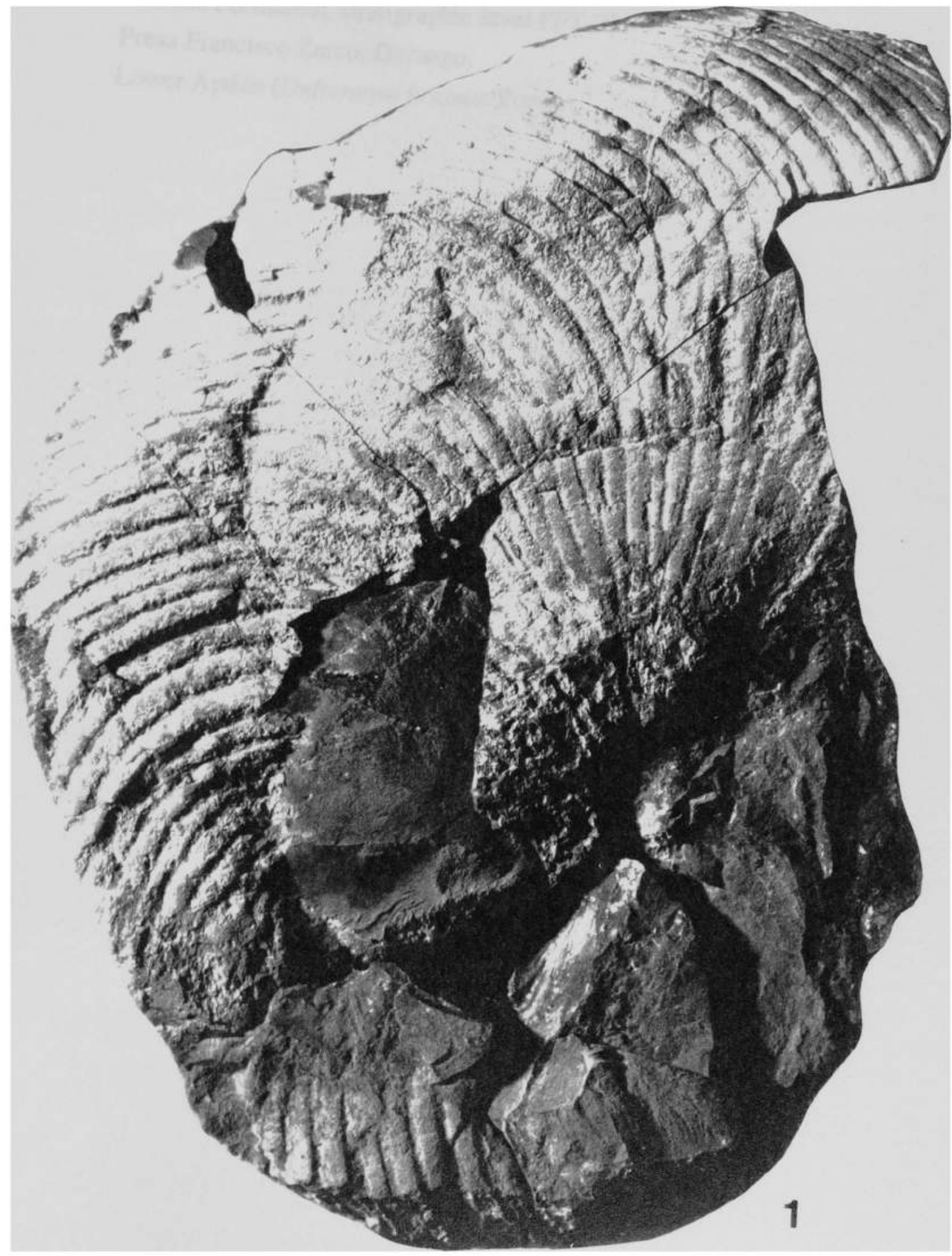




\section{PLATE 48}

Figure 1. Paracymatoceras milleri Humphrey. Specimen PFZ-0273. Ventral view.

La Peña Formation, stratigraphic level PFZ-93.

Presa Francisco Zarco, Durango.

Lower Aptian (Dufrenoyia justinae Zone). 
PLATE 48

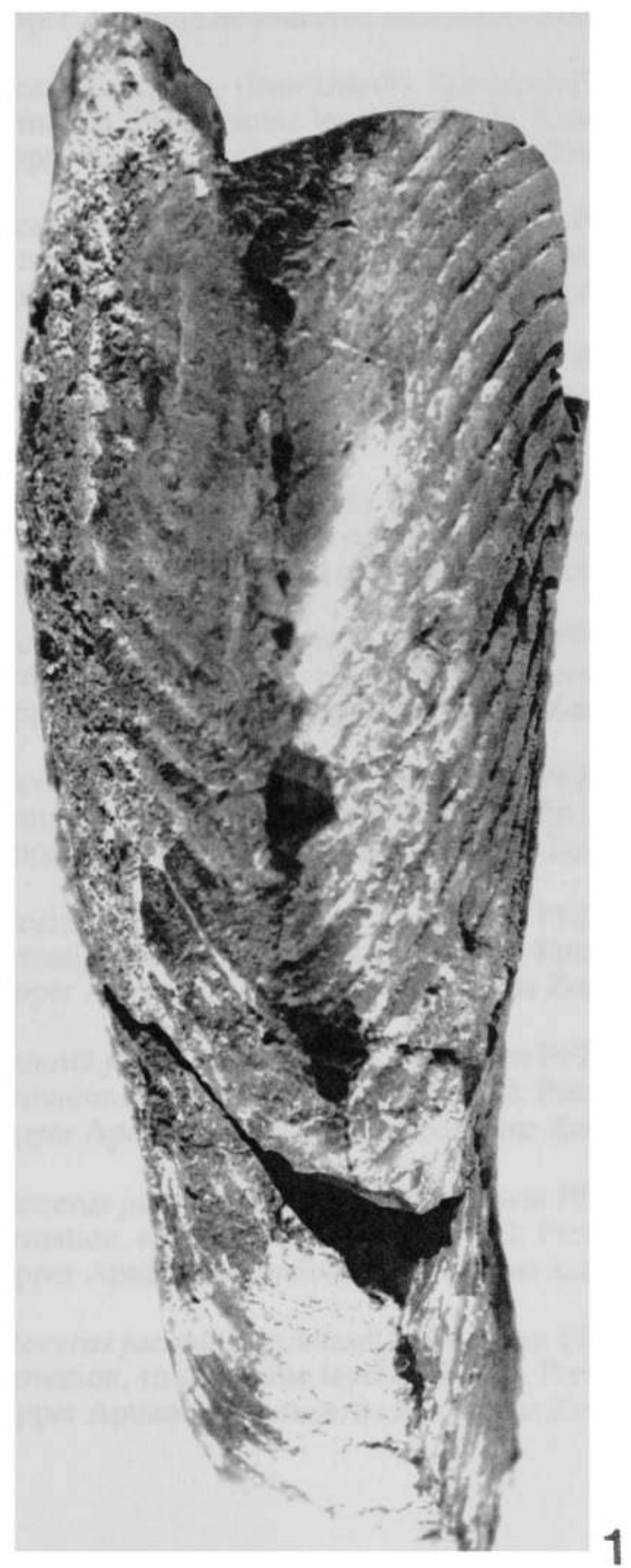




\section{PLATE 49}

Figure 1. Pseudohaploceras aguilerae (Burckhardt). Specimen PFZ-0298a.

La Peña Formation, stratigraphic level PFZ-129. Presa Francisco Zarco,

Durango. Upper Aptian (Cheloniceras inconstans Zone).

Figure 2. Pseudohaploceras aguilerae (Burckhardt). Specimen PFZ-0298b.

La Peña Formation, stratigraphic level PFZ-129. Presa Francisco Zarco,

Durango. Upper Aptian (Cheloniceras inconstans Zone).

Figure 3. Pseudohaploceras aguilerae (Burckhardt). Specimen PFZ-0303.

La Peña Formation, stratigraphic level PFZ-132. Presa Francisco Zarco,

Durango. Upper Aptian (Cheloniceras inconstans Zone).

Figure 4. Pseudohaploceras aguilerae (Burckhardt). Specimen PFZ-308.

La Peña Formation, stratigraphic level PFZ-132. Presa Francisco Zarco,

Durango. Upper Aptian (Cheloniceras inconstans Zone).

Figure 5. Pseudohaploceras jacobi (Burckhardt). Specimen PFZ-0139, side view.

La Peña Formation, stratigraphic level PFZ-132. Presa Francisco Zarco,

Durango. Upper Aptian (Cheloniceras inconstans Zone).

Figure 6. Pseudohaploceras jacobi (Burckhardt). Specimen PFZ-0139, ventral view. La Peña Formation, stratigraphic level PFZ-132. Presa Francisco Zarco, Durango. Upper Aptian (Cheloniceras inconstans Zone).

Figure 7. Pseudohaploceras jacobi (Burckhardt). Specimen PFZ-0144.

La Peña Formation, stratigraphic level PFZ-132. Presa Francisco Zarco,

Durango. Upper Aptian (Cheloniceras inconstans Zone).

Figure 8. Pseudohaploceras jacobi (Burckhardt). Specimen PFZ-0149.

La Peña Formation, stratigraphic level PFZ-132. Presa Francisco Zarco, Durango. Upper Aptian (Cheloniceras inconstans Zone).

Figure 9. Pseudohaploceras jacobi (Burckhardt). Specimen PFZ-0159.

La Peña Formation, stratigraphic level PFZ-132. Presa Francisco Zarco, Durango. Upper Aptian (Cheloniceras inconstans Zone).

Figure 10. Pseudolaaploceras jacobi (Burckhardt). Specimen PFZ-0164.

La Peña Formation, stratigraphic level PFZ-132. Presa Francisco Zarco, Durango. Upper Aptian (Cheloniceras inconstans Zone).

Figure 11. Pseudohaploceras jacobi (Burckhardt). Specimen PFZ-0169.

La Peña Formation, stratigraphic level PFZ-134. Presa Francisco Zarco, Durango. Upper Aptian (Cheloniceras inconstans Zone). 
PLATE 49
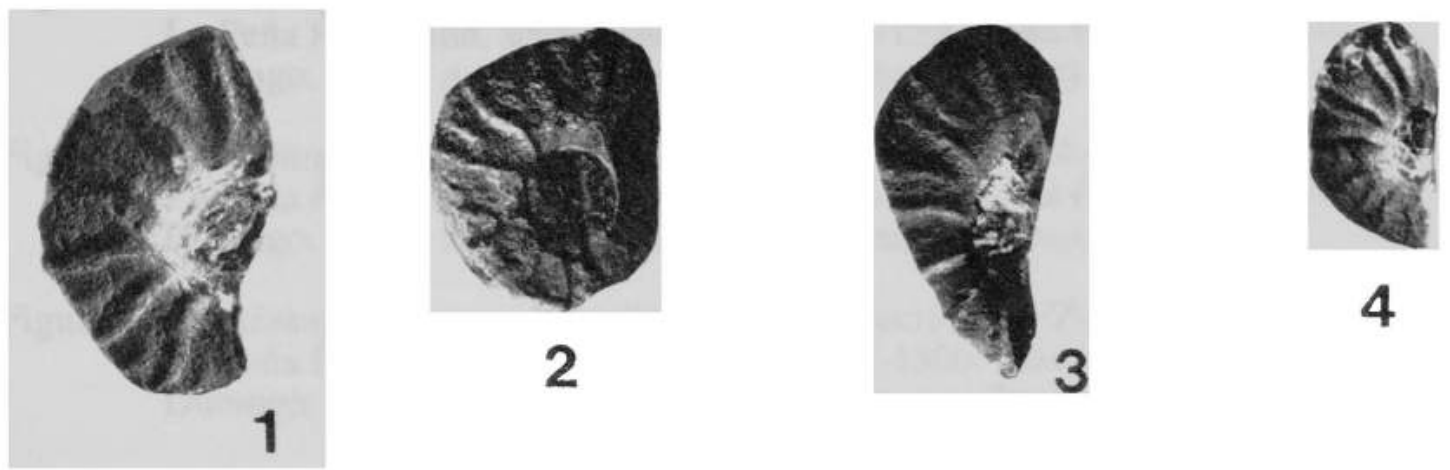

4
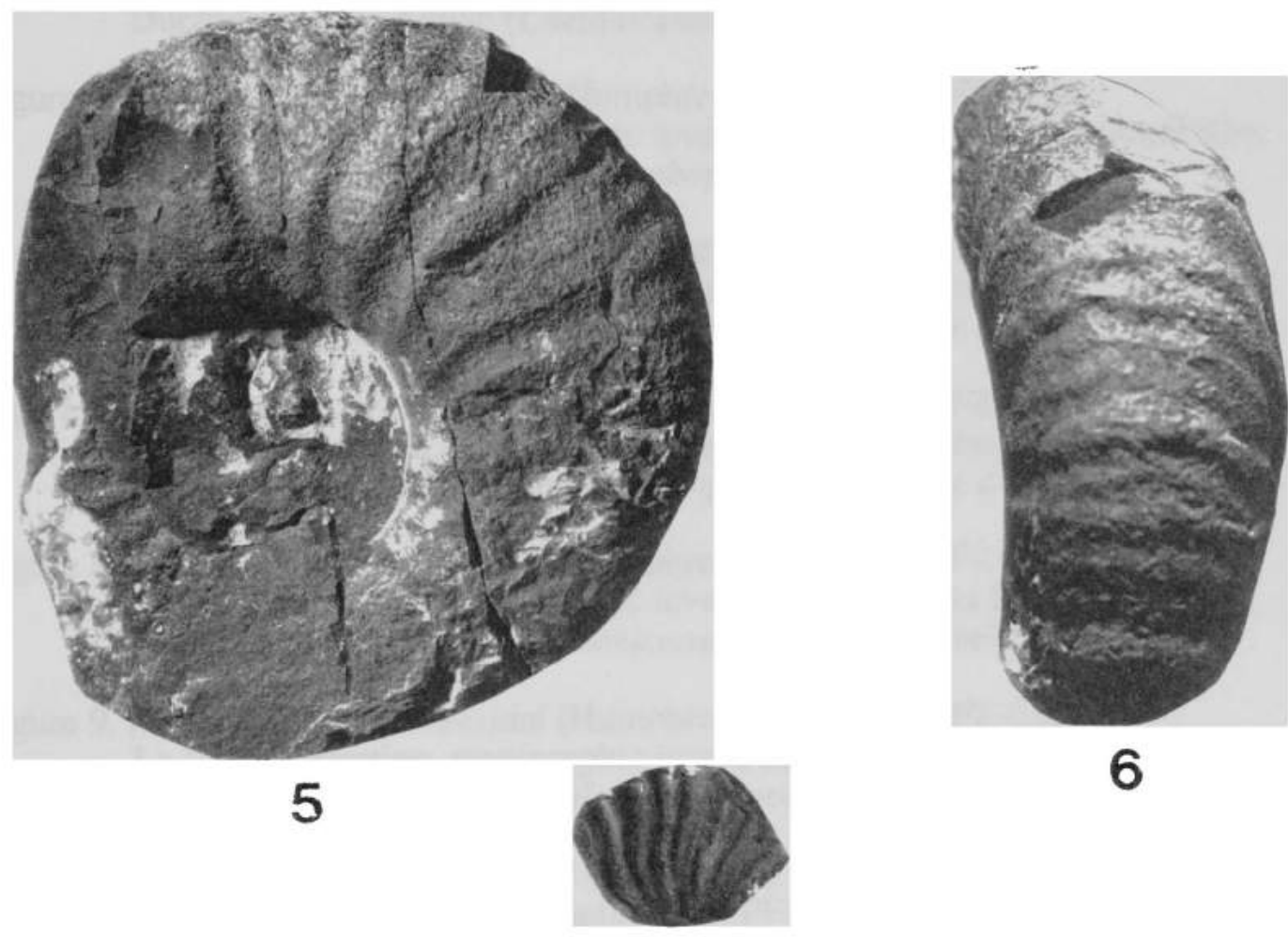

6

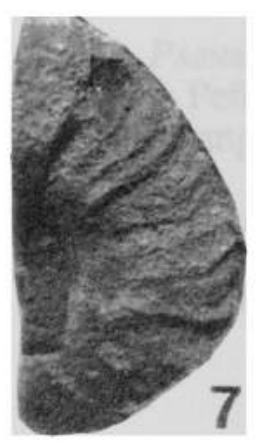

8

9
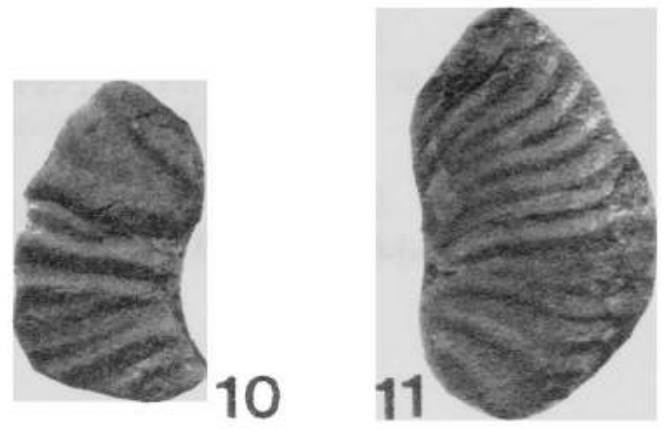


\section{PLATE 50}

Figure 1. Pseudohaploceras reesidei (Humphrey). Specimen PFZ-0104, side view. La Peña Formation, stratigraphic level PFZ-132. Presa Francisco Zarco, Durango. Upper Aptian (Cheloniceras inconstans Zone).

Figure 2. Pseudohaploceras reesidei (Humphrey). Specimen PFZ-0104, ventral view.

La Peña Formation, stratigraphic level PFZ-132. Presa Francisco Zarco,

Durango. Upper Aptian (Cheloniceras inconstans Zone).

Figure 3. Pseudohaploceras reesidei (Humphrey). Specimen PFZ-0109.

La Peña Formation, stratigraphic level PFZ-136b. Presa Francisco Zarco,

Durango. Upper Aptian (Cheloniceras inconstans Zone).

Figure 4. Pseudohaploceras reesidei (Humphrey). Specimen PFZ-0114.

La Peña Formation, stratigraphic level PFZ-136b. Presa Francisco Zarco,

Durango. Upper Aptian (Cheloniceras inconstans Zone).

Figure 5. Pseudohaploceras reesidei (Humphrey). Specimen PFZ-0124.

La Peña Formation, stratigraphic level PFZ-142b. Presa Francisco Zarco, Durango. Upper Aptian (Hypacanthoplites cf. leanzae Zone).

Figure 6. Pseudohaploceras reesidei (Humphrey). Specimen PFZ-0129.

La Peña Formation, stratigraphic level PFZ 142b. Presa Francisco Zarco, Durango. Upper Aptian (Hypacanthoplites cf. leanzae Zone).

Figure 7. Pseudohaploceras reesidei (Humphrey). Specimen PFZ-0134.

La Peña Formation, stratigraphic level PFZ-142b. Presa Francisco Zarco, Durango. Upper Aptian (Hypacanthoplites cf. leanzae Zone).

Figure 8. Pseudohaploceras reesidei (Humphrey). Specimen PFZ-0318.

La Peña Formation, stratigraphic level PFZ-129. Presa Francisco Zarco, Durango. Upper Aptian (Cheloniceras inconstans Zone).

Figure 9. Pseudohaploceras reesidei (Humphrey). Specimen PFZ-0328. La Peña Formation, stratigraphic level PFZ-132. Presa Francisco Zarco, Durango. Upper Aptian (Cheloniceras inconstans Zone).

Figure 10. Pseudohaploceras reesidei (Humphrey). Specimen PFZ-343.

La Peña Formation, stratigraphic level PFZ-132. Presa Francisco Zarco, Durango. Upper Aptian (Cheloniceras inconstans Zone).

Figure 11. Pseudohaploceras reesidei (Humphrey). Specimen PFZ 0348. La Pena Formation, stratigraphic level PFZ-132. Presa Francisco Zarco, Durango. Upper Aptian (Cheloniceras inconstans Zone).

Figure 12. Pseudohaploceras reesidei (Humphrey). Specimen LBC-0112. La Peña Formation, stratigraphic level LB I-52. La Boca Canyon, Nuevo Leon. Upper Aptian. 
Figure 13. Pseudohaploceras reesidei (Humphrey). Specimen LBC-0206. La Peña Formation, stratigraphic level LB K-2. La Boca Canyon, Nuevo Leon. Upper Aptian.

Figure 14. Pseudohaploceras reesidei (Humphrey). Specimen LBC-0098. La Peña Formation, stratigraphic level LB I-43. La Boca Canyon, Nuevo Leon. Upper Aptian.

Figure 15. Pseudohaploceras reesidei (Humphrey). Specimen LBC-0108. La Peña Formation, stratigraphic level LB 1-52. La Boca Canyon, Nuevo Leon. Upper Aptian.

Figure 16. Pseudohaploceras reesidei (Humphrey). Specimen LBC-0109. La Peña Formation, stratigraphic level LB I-52. La Boca Canyon, Nuevo Leon. Upper Aptian. 
PLATE 50
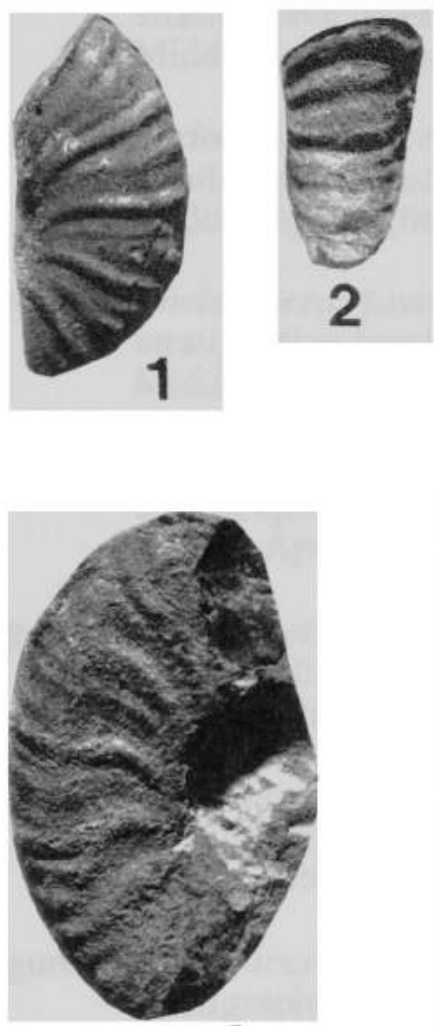

6

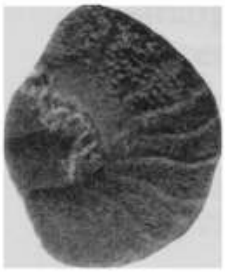

10

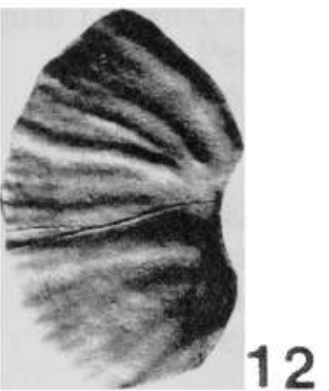

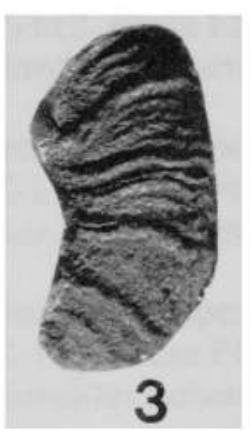
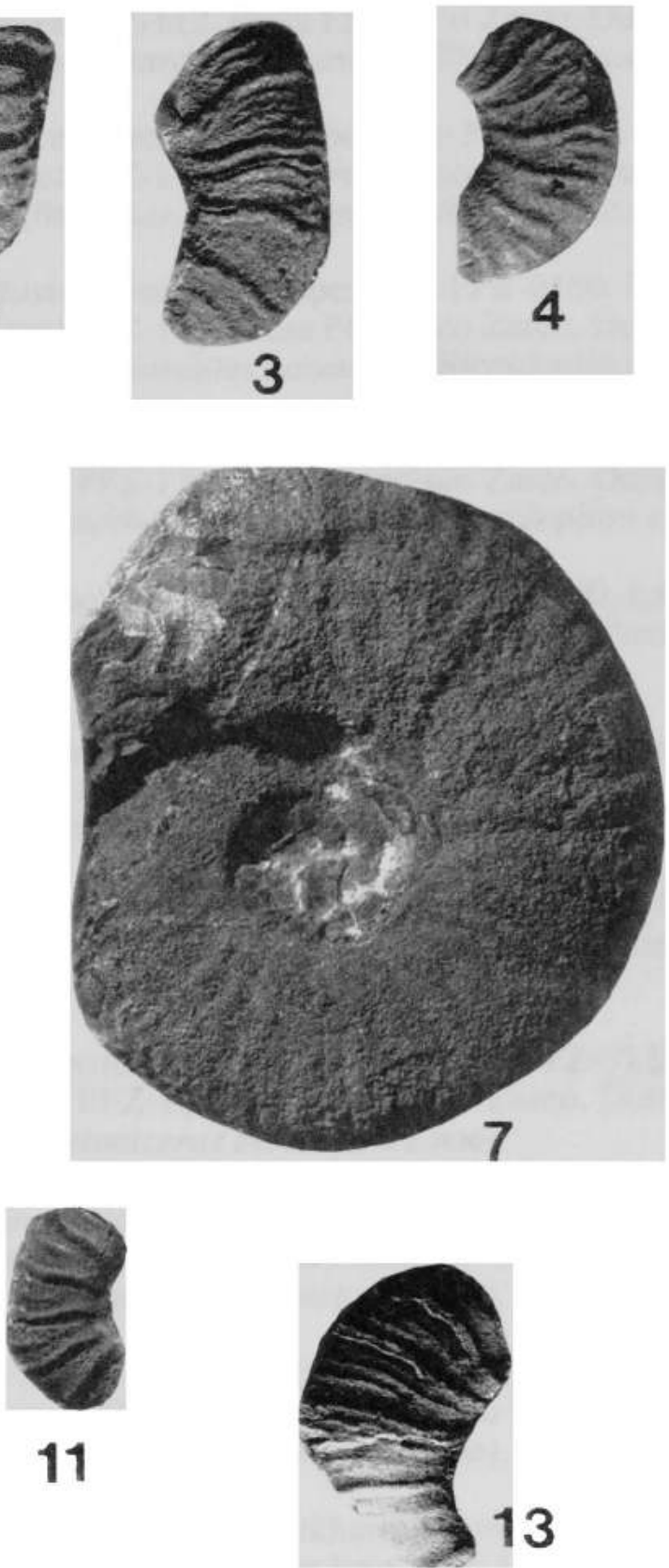

11

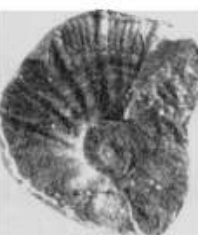

15
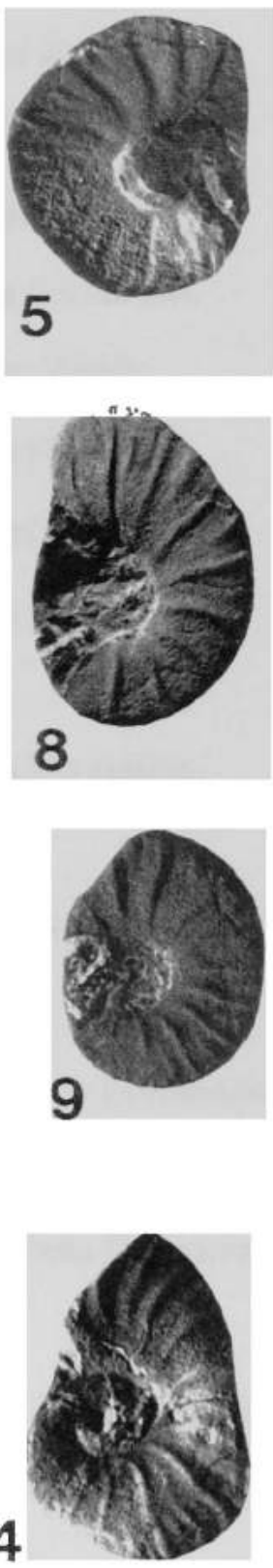

14

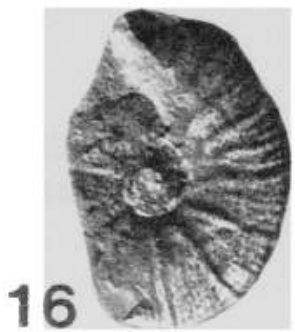




\section{PLATE 51}

Figure 1. Peltocrioceras (?) sp. Specimen PFZ-0293. La Peña Formation, stratigraphic level PFZ-112. Presa Francisco Zarco, Durango.

Middle Aptian (Burckhardites nazasensis/Rhytidoplites robertsi Zone).

Figure 2. Acrioceras (Epacrioceras) (?) sp. Specimen PFZ-0288. La Peña Formation, stratigraphic level PFZ-112. Presa Francisco Zarco, Durango.

Middle Aptian (Burckhardtites nazasensis/Rhytidoplites robertsi Zone).

Figure 3. Cheloniceras fossae Humphrey. Specimen PFZ-0I50. La Peña Formation, stratigraphic level PFZ-1 10. Presa Francisco Zarco, Durango.

Middle Aptian (Burckhardtites nazasensis/Rhytidoplites robertsi Zone).

Figure 4. Cheloniceras fossae Humphrey. Specimen PFZ-0155. La Peña Formation, stratigraphic level PFZ-112. Presa Francisco Zarco, Durango.

Middle Aptian (Burckhardtites nazasensis/Rhytidoplites robertsi Zone).

Figure 5. Cheloniceras fossae Humphrey. Specimen PFZ-0160. La Peña Formation, stratigraphic level PFZ-129. Presa Francisco Zarco, Durango.

Upper Aptian (Cheloniceras inconstans Zone),

Figure 6. Cheloniceras fossae Humphrey. Specimen PFZ-0165. La Peña Formation, stratigraphic level PFZ-129. Presa Francisco Zarco, Durango. Upper Aptian (Cheloniceras ilconstans Zone).

Figure 7. Cheloniceras fossae Humphrey. Specimen PFZ-0170. La Peña Formation, stratigraphic level PFZ-140b. Presa Francisco Zarco, Durango.

Upper Aptian (Chelouiceras inconstans Zone).

Figure 8. Cheloniceras inconstans Humphrey. Specimen PFZ-0125. La Peña Formation, stratigraphic level PFZ-125. Presa Francisco Zarco, Durango.

Upper Aptian (Cheloniceras inconstants Zone),

Figure 9. Cheloniceras inconstans Humphrey. Specimen PFZ-0130. La Peña Formation, stratigraphic level PFZ-132. Presa Francisco Zarco, Durango.

Upper Aptian (Cheloniceras inconstans Zone).

Figure 10. Cheloniceras inconstans Humphrey. Specimen PFZ-0140. La Peña Formation, stratigraphic level PFZ-136b. Presa Francisco Zarco, Durango.

Upper Aptian (Cheloniceras inconstans Zone).

Figure 11. Burckhardtites nazasensis (Burckhardt). Specimen PFZ-0352.

La Pefia Formation, stratigraphic level PFZ-101. Presa Francisco Zarco, Durango. Middle Aptian

(Burckhardtites nazasensis/Rlytidoplites robertsi Zone).

Figure 12. Burckhardtites nazasensis (Burckhardt). Specimen PFZ-0103.

La Peña Formation, stratigraphic level PFZ-104. Presa Francisco Zarco, Durango. Middle Aptian

(Burckhardtites nazasensis/Rhytidoplites robertsi Zone). 
Figure 13. Burckhardtites nazasensis (Burckhardt). Specimen PFZ-0113.

La Peña Formation, stratigraphic level PFZ-106. Presa Francisco Zarco, Durango. Middle Aptian

(Burckhardites nazasensis/Rhytidoplites robertsi Zone).

Figure 14. Burckhardtites nazasensis (Burckhardt). Specimen PFZ-0347.

La Peña Formation, stratigraphic level PFZ-106. Presa Francisco Zarco, Durango. Middle Aptian

(Burckhardtites nazasensis/Rhytidoplites robertsi Zone). 


\section{PLATE 51}
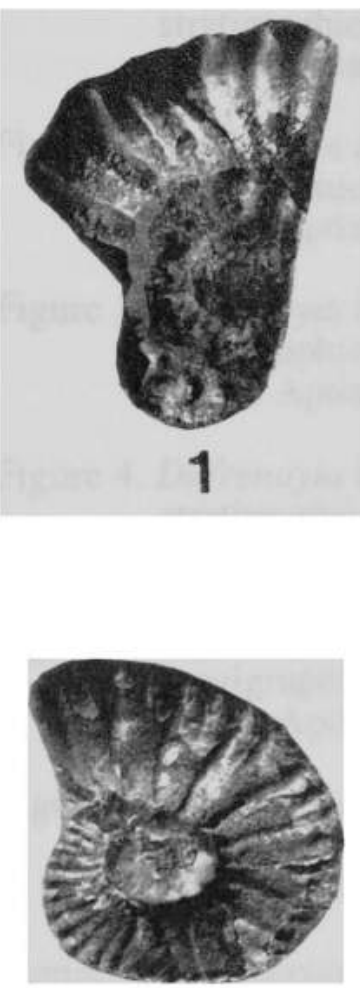

5

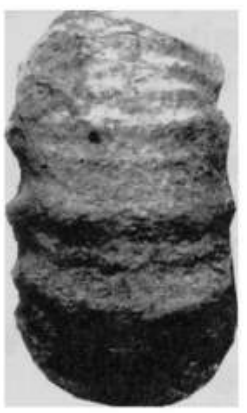

9

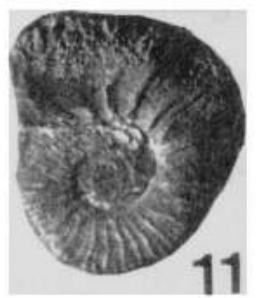

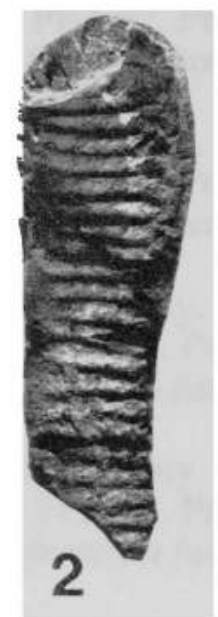

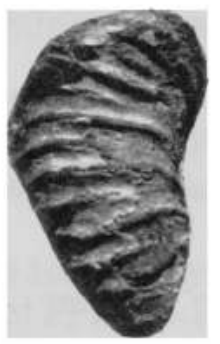

6
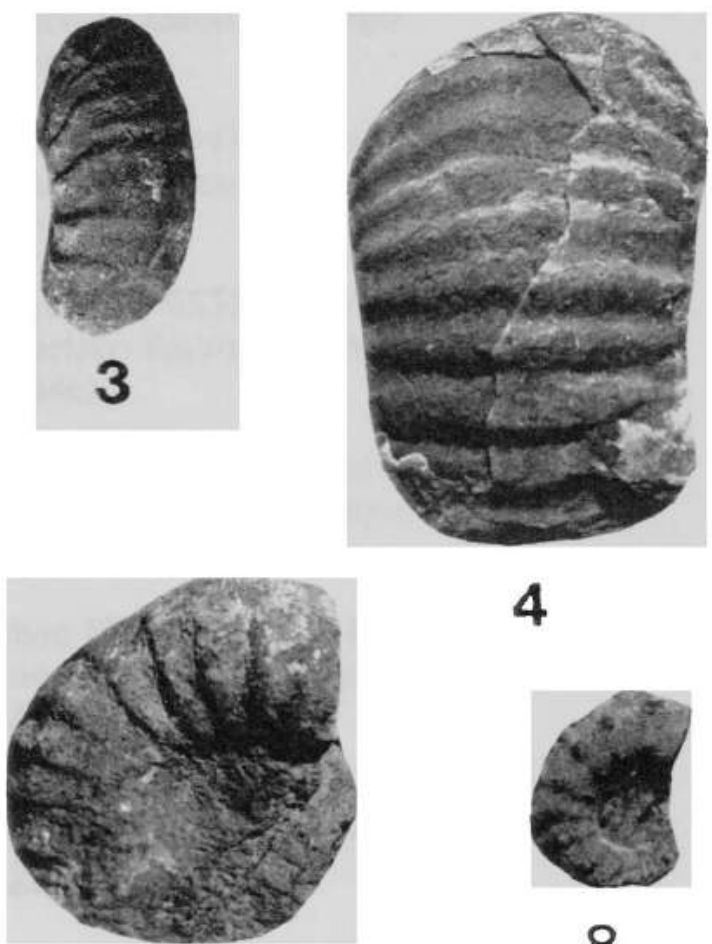

4

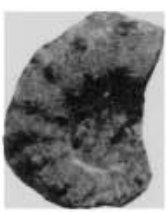

8

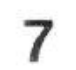

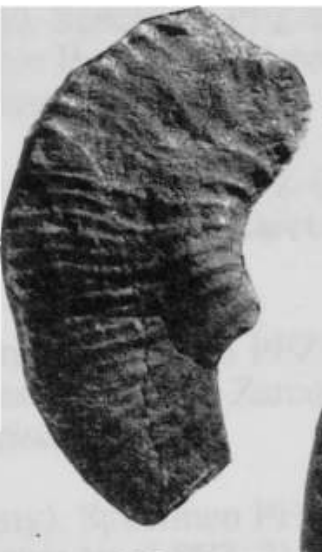

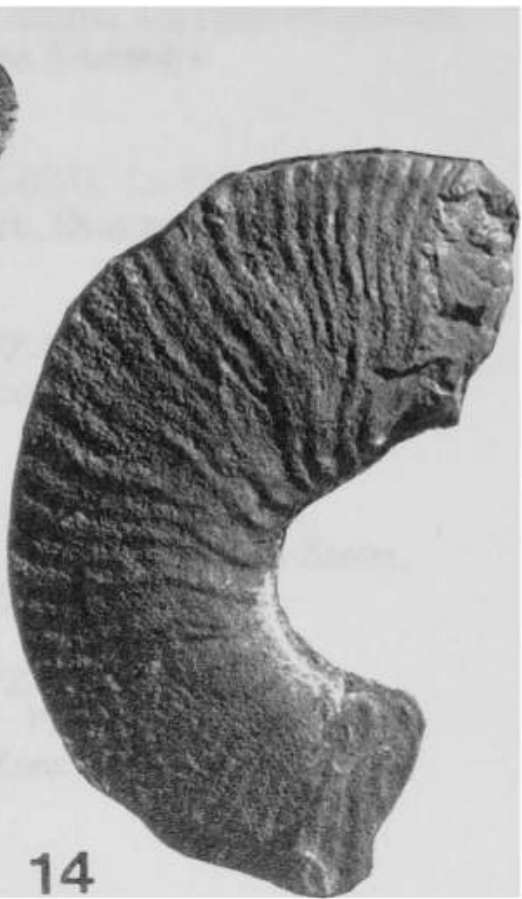




\section{PLATE 52}

Figure 1. Dufrenoyia bösei Humphrey. Specimen PFZ-0330a. La Peña Formation, stratigraphic level PFZ-67. Presa Francisco Zarco, Durango.

Lower Aptian (Dufrenoyia justinae Zone).

Figure 2. Dufrenoyia bösei Humphrey. Specimen PFZ-0341. La Peña Formation, stratigraphic level PFZ-67. Presa Francisco Zarco, Durango.

Lower Aptian (Dufrenoyia justinae Zone).

Figure 3. Dufrenoyia bösei Humphrey. Specimen PFZ-0351. La Peña Formation, stratigraphic level PFZ-67. Presa Francisco Zarco, Durango.

Lower Aptian (Dufrenoyia justinae Zone).

Figure 4. Dufrenoyia bösei Humphrey. Specimen PFZ 0102. La Peña Formation, stratigraphic level PFZ-67. Presa Francisco Zarco, Durango.

Lower Aptian (Dufrenoyia justinae Zone).

Figure 5. Dufrenoyia bösei Humphrey. Specimen PFZ-0145b. La Peña Formation, stratigraphic level PFZ-69. Presa Francisco Zarco, Durango.

Lower Aptian (Dufrenoyia justinae Zone).

Figure 6. Dufrenoyia bösei Humphrey. Specimen PFZ-0190b. La Peña Formation, stratigraphic level PFZ-85. Presa Francisco Zarco, Durango.

Lower Aptian (Dufrenoyia justinae Zone).

Figure 7. Dufrenoyia bösei Humphrey. Specimen PFZ-0326. La Peña Formation, stratigraphic level PFZ-85. Presa Francisco Zarco, Durango.

Lower Aptian (Dufrenoyia justinae Zone).

Figure 8. Dufrenoyia dufrenoyi (Orbigny). Specimen PFZ-0226a. La Peña Formation, stratigraphic level PFZ-67. Presa Francisco Zarco, Durango.

Lower Aptian (Dufrenoyia justinae Zone).

Figure 9. Dufrenoyia dufrenoyi (Orbigny). Specimen PFZ-0241. La Peña Formation, stratigraphic level PFZ-67. Presa Francisco Zarco, Durango.

Lower Aptian (Dufrenoyia justinae Zone).

Figure 10. Dufrenoyia dufrenoyi (Orbigny). Specimen PFZ-0266. La Peña Formation, stratigraphic level PFZ-67. Presa Francisco Zarco, Durango.

Lower Aptian (Dufrenoyia justinae Zone).

Figure 11. Dufrenoyia dufrenoyi (Orbigny). Specimen PFZ-0301, side view.

La Peña Formation, stratigraphic level PFZ-71. Presa Francisco Zarco, Durango. Lower Aptian (Dufrenoyia justinae Zone).

Figure 12. Dufrenoyia dufrenoyi (Orbigny). Specimen PFZ-0301, ventral view.

La Peña Formation, stratigraphic level PFZ-71. Presa Francisco Zarco, Durango. Lower Aptian (Dufrenoyia justinae Zone). 
Figure 13, Dufrenoyia dufrenoyi (Orbigny). Specimen PFZ-0321. La Peña Formation, stratigraphic level PFZ-79. Presa Francisco Zarco, Durango.

Lower Aptian (Dufrenoyia justinae Zone).

Figure 14. Dufrenoyia dufrenoyi (Orbigny). Specimen PFZ-0261. La Peña Formation, stratigraphic level PFZ-93. Presa Francisco Zarco, Durango.

Lower Aptian (Dufrenoyia justinae Zone). 


\section{PLATE 52}
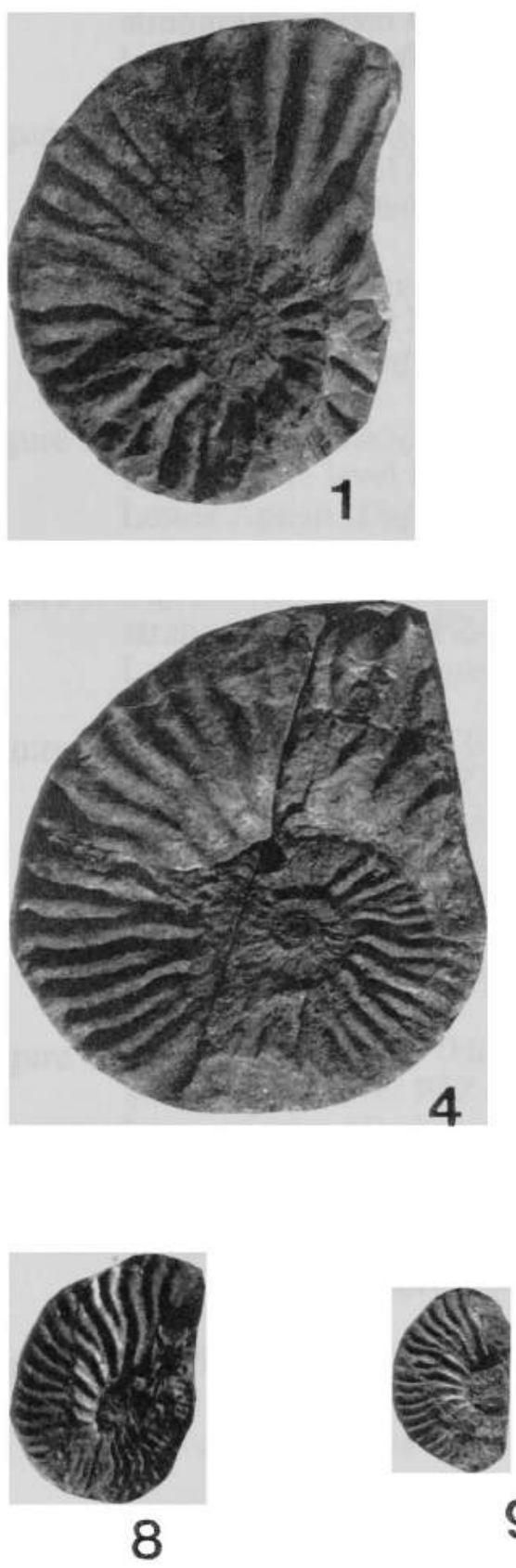

9

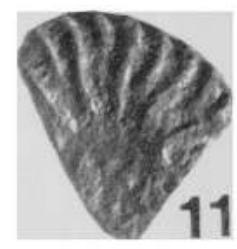

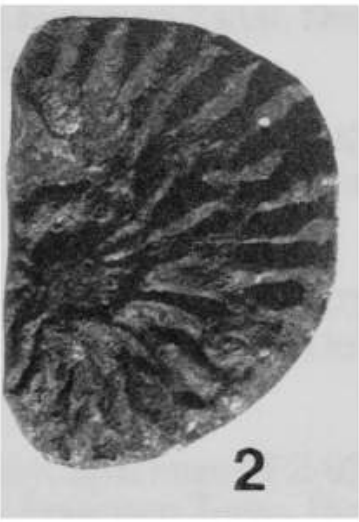

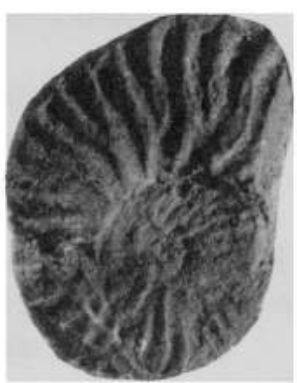

5

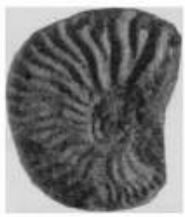

10
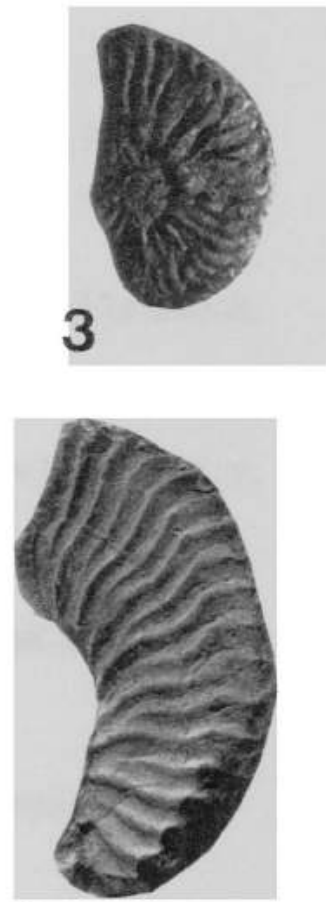

6
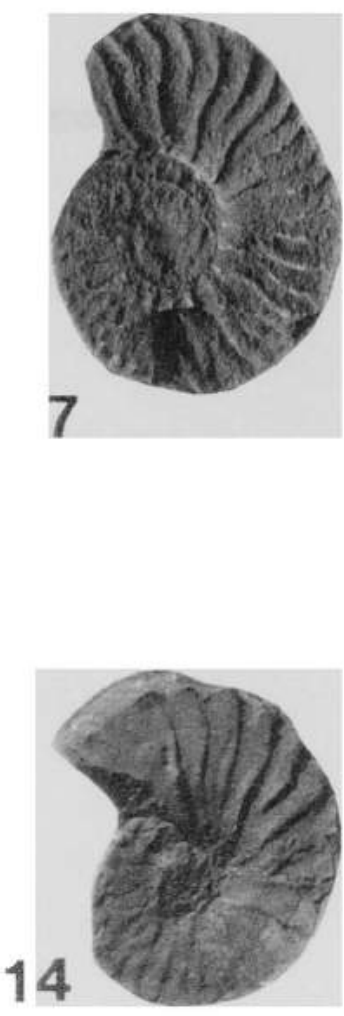


\section{PLATE 53}

Figure 1. Dufrenoyia dufrenoyi (Orbigny). Specimen PFZ-027la. La Peña Formation, stratigraphic level PFZ-93. Presa Francisco Zarco, Durango. Lower Aptian (Dufrenoyia justinae Zone).

Figure 2. Dufrenoyia durangensis Humphrey. Specimen PFZ-0297. La Peña Formation, stratigraphic level PFZ-93. Presa Francisco Zarco, Durango. Lower Aptian (Dufrenoyia justinae Zone).

Figure 3. Dufrenoyia durangensis Humphrey. Specimen PFZ-0302. La Peña Formation, stratigraphic level PFZ-81. Presa Francisco Zarco, Durango.

Lower Aptian (Dufrenoyia justinae Zone).

Figure 4. Dufrenoyia durangensis Humphrey. Specimen PFZ-0307. La Peña Formation, stratigraphic level PFZ-85. Presa Francisco Zarco, Durango.

Lower Aptian (Dufrenoyia justinae Zone).

Figure 5. Dufrenoyia justinae (Hil). Specimen PFZ-0230. La Peña Formation, stratigraphic level PFZ-65. Presa Francisco Zarco, Durango.

Lower Aptian (Dufrenoyia justinae Zone).

Figure 6. Dufrenoyia justinae (Hill). Specimen PFZ-0135. La Peña Formation, stratigraphic level PFZ-67. Presa Francisco Zarco, Durango. Lower Aptian (Dufrenoyia justinae Zone).

Figurc 7. Dufrenoyia justinae (Hill). Specimen PFZ-0185. La Peña Formation, stratigraphic level PFZ-67. Presa Francisco Zarco, Durango.

Lower Aptian (Dufrenoyia justinae Zone).

Figure 8. Dufrenoyia justinae (Hill). Specimen PFZ-0300. La Peña Formation, stratigraphic level PFZ-67. Presa Francisco Zarco, Durango. Lower Aptian (Dufrenoyia justinae Zone).

Figure 9. Dufrenoyia justinae (Hill). Specimen PFZ-0350. La Peña Formation, stratigraphic level PFZ-67. Presa Francisco Zarco, Durango.

Lower Aptian (Dufrenoyia justinae Zone).

Figure 10. Dufrenoyia justinae (Hill). Specimen PFZ-0106. La Peña Formation, stratigraphic level PFZ-67. Presa Francisco Zarco, Durango.

Lower Aptian (Dufrenoyia justinae Zone). 


\section{PLATE 53}
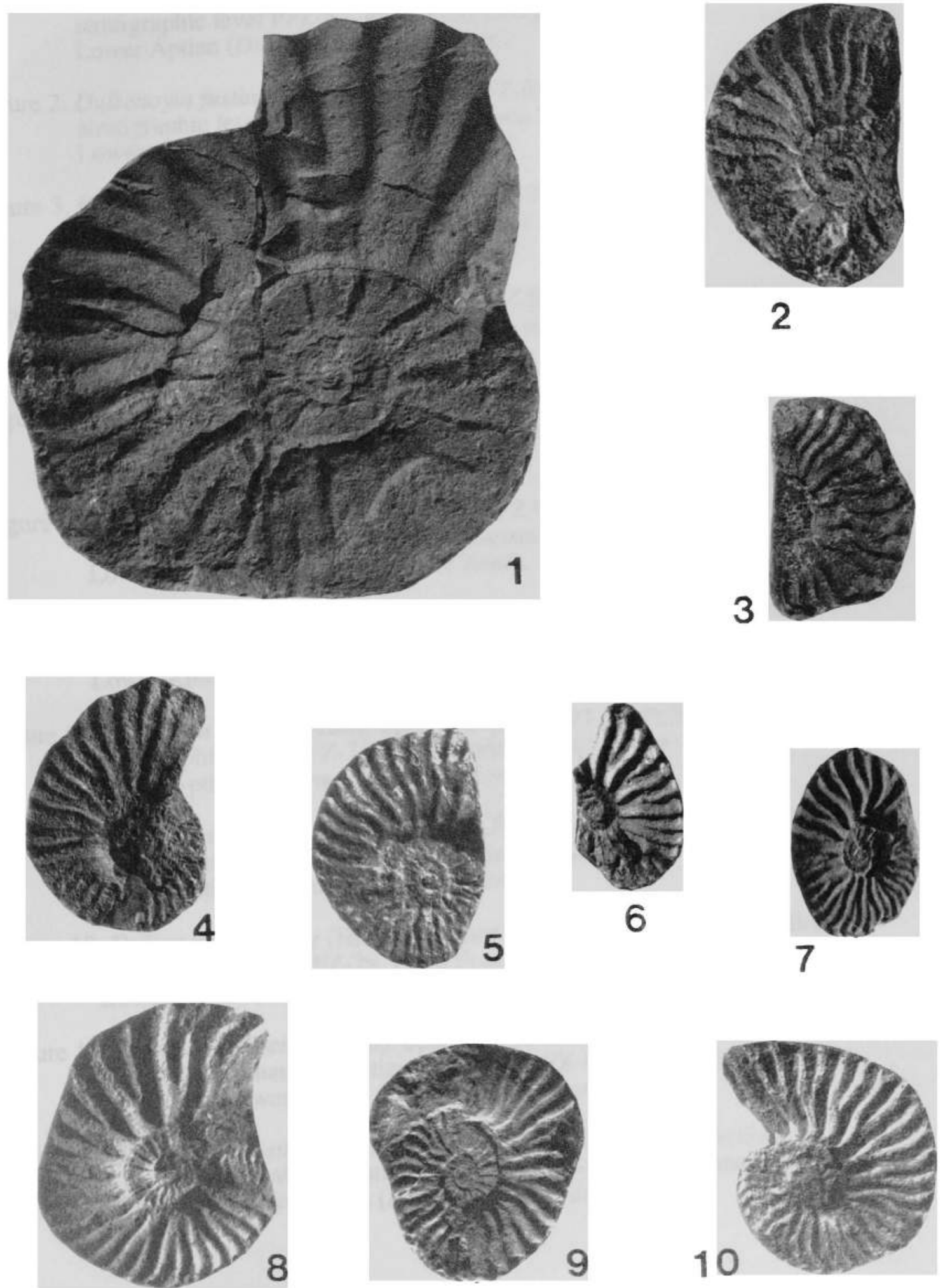


\section{PLATE 54}

Figure 1. Dufrenoyia justinae (Hill), Specimen PFZ-0126. La Peña Formation, stratigraphic level PFZ-67. Presa Francisco Zarco, Durango. Lower Aptian (Dufrenoyia justinae Zone).

Figure 2. Dufrenoyia justinae (Hill). Specimen PFZ-0131. La Peña Formation, stratigraphic level PFZ-69. Presa Francisco Zarco, Durango. Lower Aptian (Dufrenoyia justinae Zone).

Figure 3. Dufrenoyia justinae (Hill). Specimen PFZ-0146. La Peña Formation, stratigraphic level PFZ-69. Presa Francisco Zarco, Durango. Lower Aptian (Dufrenoyia justinae Zone).

Figure 4. Dufrenoyia justinae (Hill). Specimen PFZ-0180. La Peña Formation, stratigraphic level PFZ-71. Presa Francisco Zarco, Durango. Lower Aptian (Dufrenoyia justinae Zone).

Figure 5. Dufrenoyia justinae (Hill). Specimen PFZ-0265, La Peña Formation, stratigraphic level PFZ-71. Presa Francisco Zarco, Durango. Lower Aptian (Dufrenoyia justinae Zone).

Figure 6. Dufrenoyia justinae (Hil). Specimen PFZ-0270. La Peña Formation, stratigraphic level PFZ-71. Presa Francisco Zarco, Durango. Lower Aptian (Dufrenoyia justinae Zone).

Figure 7. Dufrenoyia justinae (Hill). Specimen PFZ-0175. La Peña Formation, stratigraphic level PFZ.73. Presa Francisco Zarco, Durango. Lower Aptian (Dufrenoyia justinae Zone).

Figure 8. Dufrenoyia justinae (Gill). Specimen PFZ-0191. La Peña Formation, stratigraphic level PFZ-75. Presa Francisco Zarco, Durango. Lower Aptian (Dufrenoyia justinae Zone).

Figure 9. Dufrenoyia justinae (Hill). Specimen PFZ-0110. La Peña Formation, stratigraphic level PFZ-75. Presa Francisco Zarco, Durango. Lower Aptian (Dufrenoyia justinae Zone).

Figure 10. Dufrenoyia justinae (Hill). Specimen PFZ-0181. La Peña Formation, stratigraphic level PFZ-79. Presa Francisco Zarco, Durango. Lower Aptian (Dufrenoyia justinae Zone).

Figure 11. Dufrenoyia justinae (Hill). Specimen PFZ-0295, side view. La Peña Formation, stratigraphic level PFZ-81. Presa Francisco Zarco, Durango. Lower Aptian (Dufrenoyia justinae Zone).

Figure 12. Dufrenoyia justinae (Hill). Specimen PFZ-0295, whorl section.

La Peña Formation, stratigraphic level PFZ-81. Presa Francisco Zarco, Durango. Lower Aptian (Dufrenoyia justinae Zone). 


\section{PLATE 54}
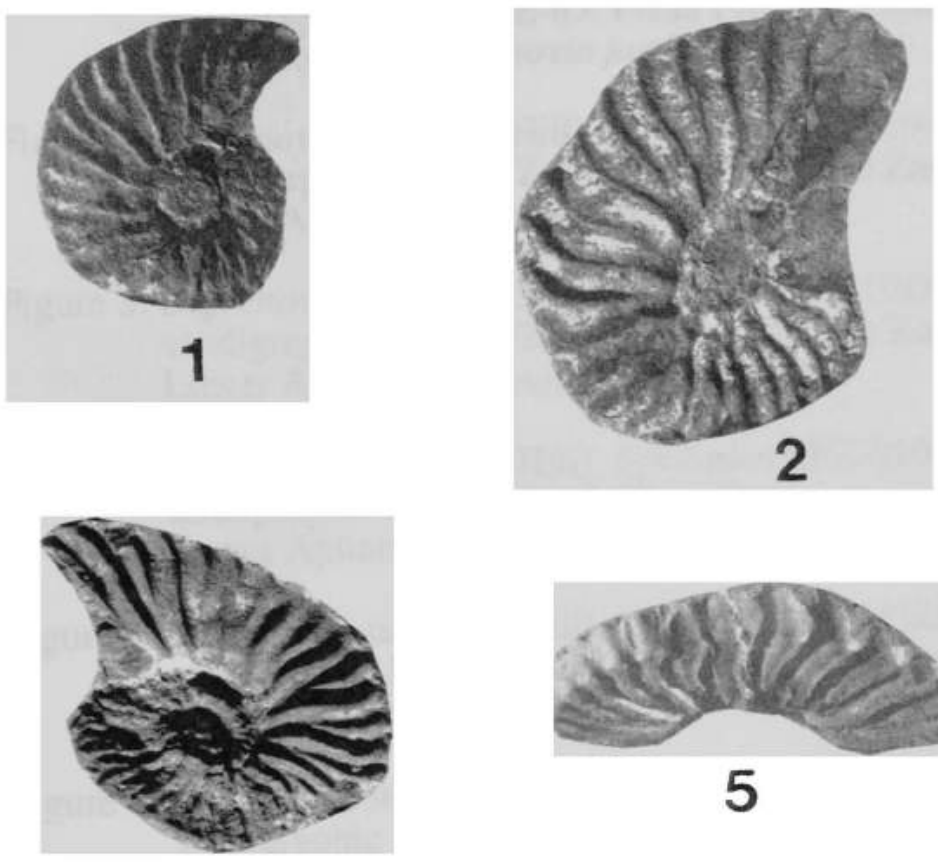

4

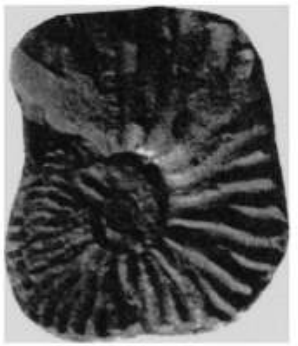

7

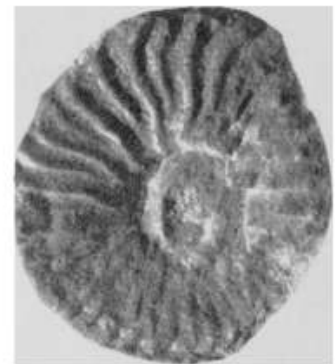

10

5

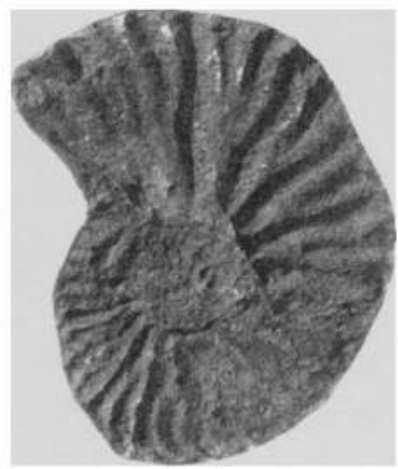

8

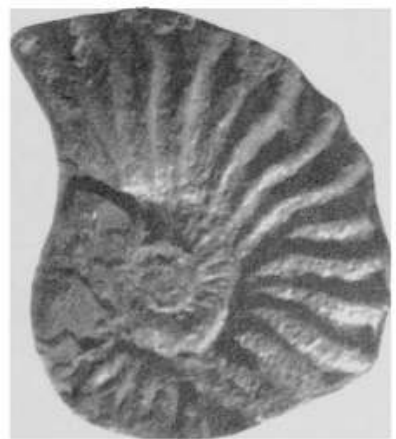

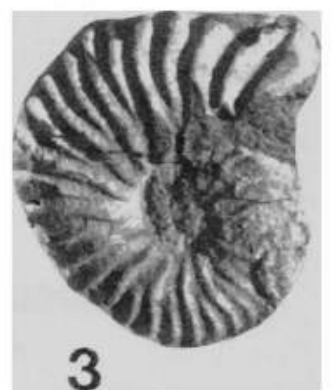
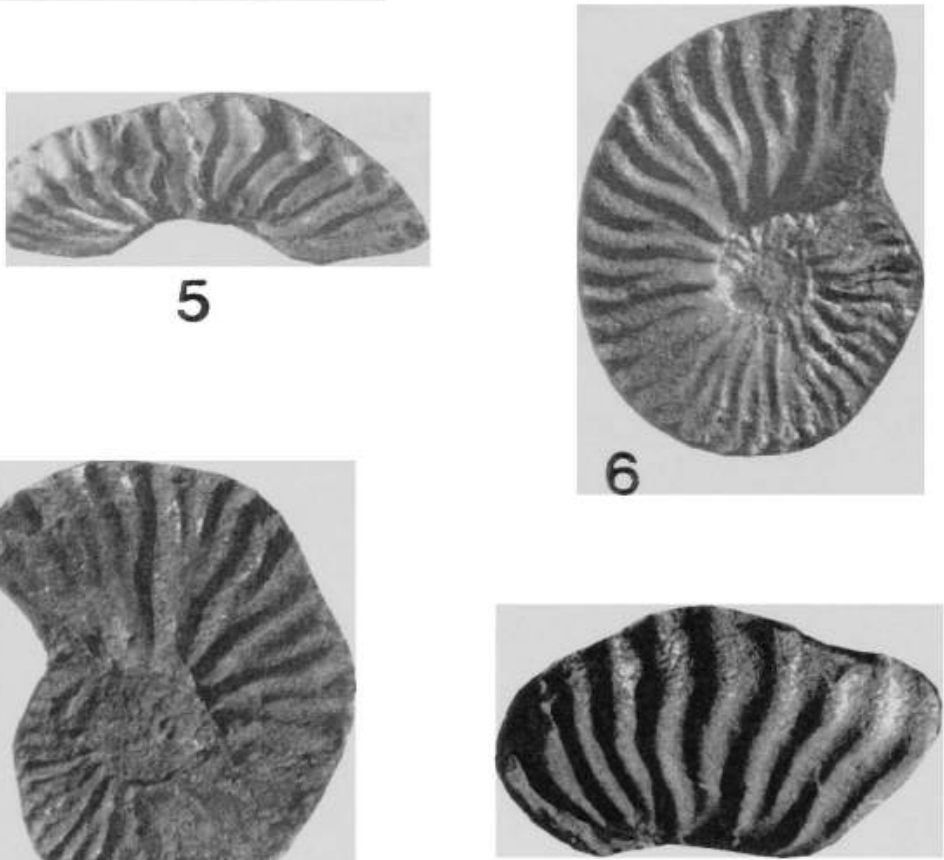

9

11

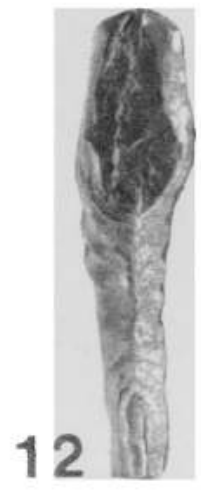




\section{PLATE 55}

Figure 1. Dufrenoyia justinae (Hill). Specimen PFZ 0115. La Peña Formation, stratigraphic level PFZ-85. Presa Francisco Zarco, Durango.

Lower Aptian (Dufrenoyia justinae Zone).

Figure 2. Dufrenoyia justinae (Hill). Specimen PFZ-0190. La Peña Formation, stratigraphic level PFZ-85. Presa Francisco Zarco, Durango.

Lower Aptian (Dufrenoyia justinae Zone).

Figure 3. Dufrenoyia justinae (Hill). Specimen PFZ-0200. La Peña Formation, stratigraphic level PFZ-93. Presa Francisco Zarco, Durango.

Lower Aptian (Dufrenoyia justillae Zone).

Figure 4. Dufrenoyia justinae (Hill). Specimen PFZ-0105. La Peña Formation, stratigraphic level PFZ-93. Presa Francisco Zarco, Durango.

Lower Aptian (Dufrenoyia justinae Zone).

Figure 5. Dufrenoyia justinae (Hill). Specimen LBC-0002. La Peña Formation, stratigraphic level LBC A.17. La Boca Canyon, Nuevo Leon.

Lower Aptian.

Figure 6. Dufrenoyia justinae (Hill). Specimen LBC-0024. La Peña Formation, stratigraphic level LBC E-4. La Boca Canyon, Nuevo Leon.

Lower Aptian. 


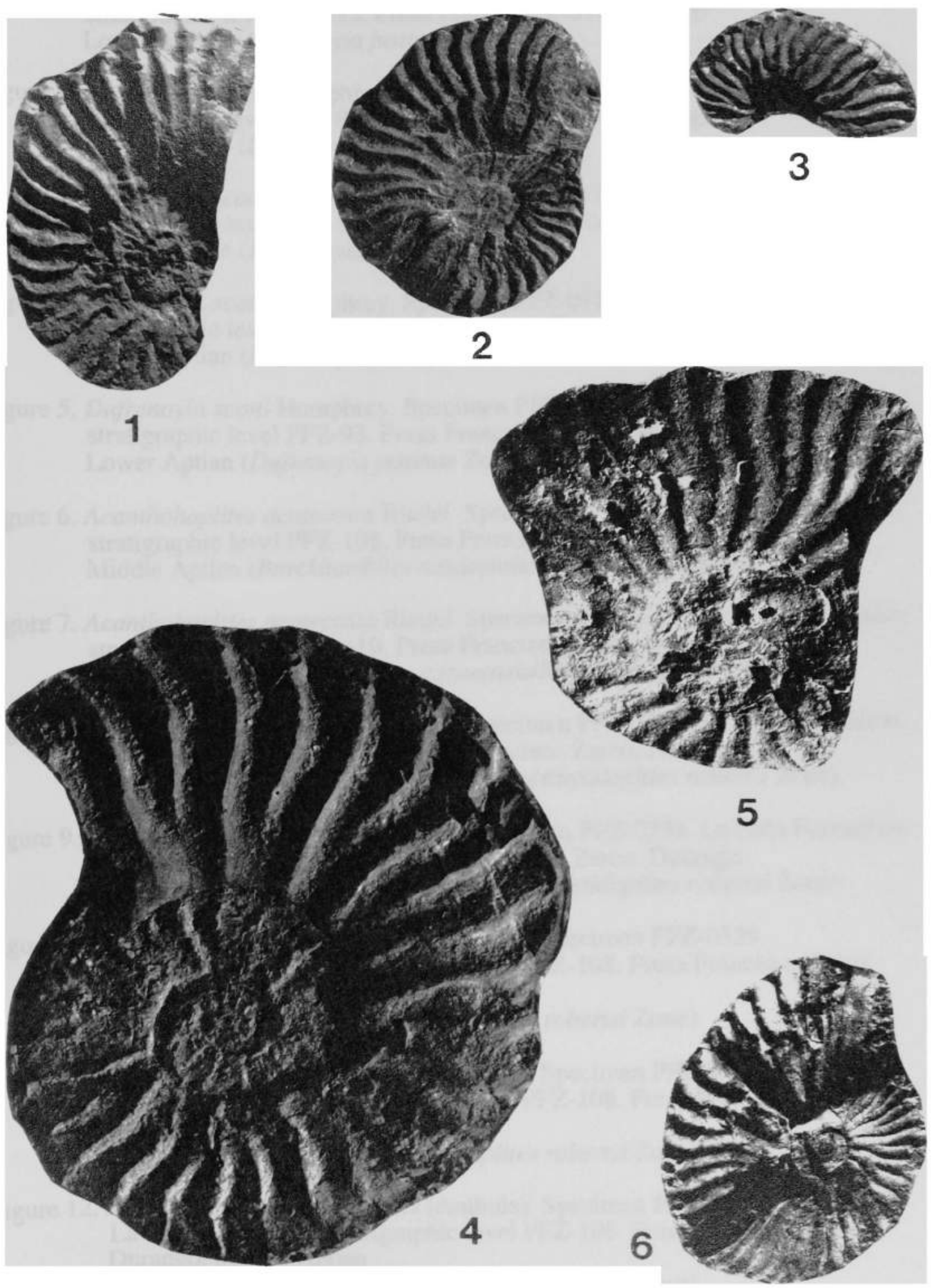




\section{PLATE 56}

Figure 1. Dufrenoyia scotti Humphrey. Specimen PFZ 0112. La Peña Formation, stratigraphic level PFZ-93. Presa Francisco Zarco, Durango.

Lower Aptian (Dufrenoyia justinae Zone).

Figure 2. Dufrenoyia scotti Humphrey. Specimen PFZ-0122. La Peña Formation, stratigraphic level PFZ-93. Presa Francisco Zarco, Durango.

Lower Aptian (Dufrenoyia justinae Zone).

Figure 3. Dufrenoyia scotti Humphrey. Specimen PFZ-0127. La Peña Formation, stratigraphic level PFZ-93. Presa Francisco Zarco, Durango.

Lower Aptian (Dufrenoyia justinae Zone).

Figure 4. Dufrenoyia scotti Humphrey. Specimen PFZ-0182. La Peña Formation, stratigraphic level PFZ-93. Presa Francisco Zarco, Durango. Lower Aptian (Dufrenoyia justinae Zone).

Figure 5. Dufrenoyia scotti Humphrey. Specimen PFZ-0192. La Peña Formation, stratigraphic level PFZ-93. Presa Francisco Zarco, Durango.

Lower Aptian (Dufrenoyia justinae Zone).

Figure 6. Acanthohoplites acutecosta Riedel. Specimen PFZ-0314. La Peña Formation, stratigraphic level PFZ-108. Presa Francisco Zarco, Durango. Middle Aptian (Burckhardtites nazasensis/Rhytidoplites robertsi Zone).

Figure 7. Acanthohoplites acutecosta Riedel. Specimen PFZ-0319. La Peña Formation, stratigraphic level PFZ-110. Presa Francisco Zarco, Durango. Middle Aptian (Burckhardtites nazasensis/Rhytidoplites robertsi Zone).

Figure 8. Acanthohoplites acutecosta Riedel. Specimen PFZ-0208. La Peña Formation, stratigraphic level PFZ-110. Presa Francisco Zarco, Durango. Middle Aptian (Burckhardtites nazasensis/Rhytidoplites robertsi Zone).

Figure 9. Acanthohoplites acutecosta Riedel. Specimen PFZ-0324. La Peña Formation, stratigraphic level PFZ-112. Presa Francisco Zarco, Durango.

Middle Aptian (Burckhardtites nazasensis/Rhytidoplites robensi Zone).

Figure 10. Acanthohoplites aschiltaensis (Anthula). Specimen PFZ-0339.

La Peña Formation, stratigraphic level PFZ-108. Presa Francisco Zarco, Durango. Middle Aptian (Burckhardtites nazasensis/Rhytidoplites robertsi Zone).

Figure 11. Acanthohoplites aschiltaensis (Anthula). Specimen PFZ-0309.

La Peña Formation, stratigraphic level PFZ-108. Presa Francisco Zarco, Durango. Middle Aptian

(Burckhardtites nazasensis/Rhytidoplites robentsi Zone).

Figure 12. Acanthohoplites aschiltaensis (Anthula). Specimen PF7,-0344.

La Peña Formation, stratigraphic level PFZ-108. Presa Francisco Zarco, Durango. Middle Aptian

(Burckhardtites nazasensis/Rhytidoplites robertsi Zone). 
Figure 13. Acanthohoplites aschiltaensis (Anthula). Specimen PFZ-0354.

La Peña Formation, stratigraphic level PFZ-125. Presa Francisco Zarco,

Durango. Upper Aptian (Cheloniceras inconstans Zone).

Figure 14. Acanthohoplites aschiltaensis (Anthula). Specimen PFZ-0120.

La Peña Formation, stratigraphic level PFZ-132. Presa Francisco Zarco, Durango. Upper Aptian (Cheloniceras inconstans Zone).

Figure 15. Acanthohoplites aschiltaensis (Anthula). Specimen LBC-0143.

La Peña Formation, stratigraphic level LBC K-2. La Boca Canyon, Nuevo Leon. Upper Aptian.

Figure 16. Acanthohoplites aschiltaensis (Anthula). Specimen LBC-0200.

La Peña Formation, stratigraphic level LBC K-2. La Boca Canyon, Nuevo Leon. Upper Aptian. 


\section{PLATE 56}

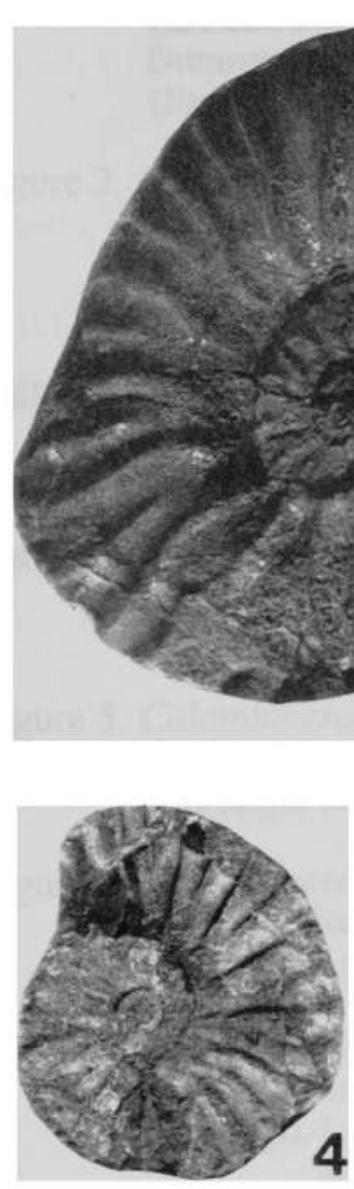

\section{1}

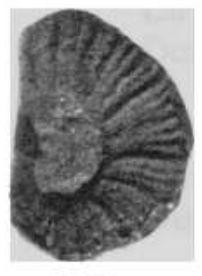

10

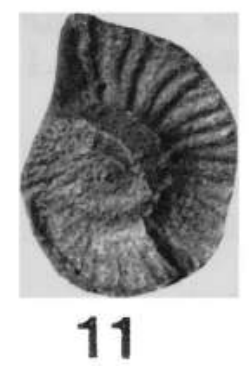

11

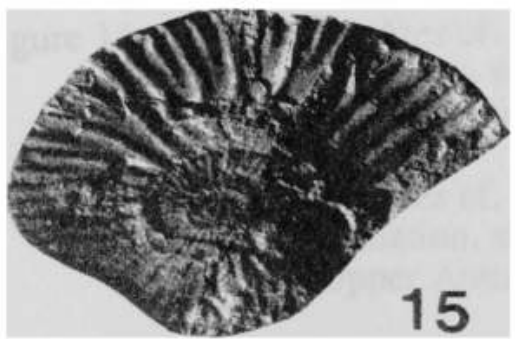

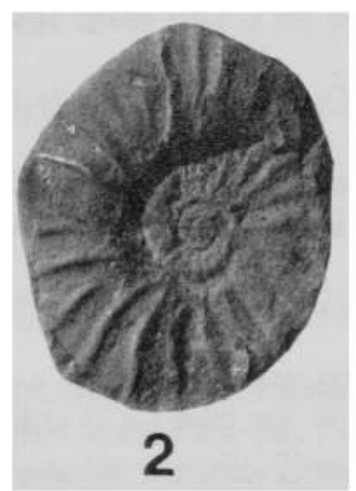
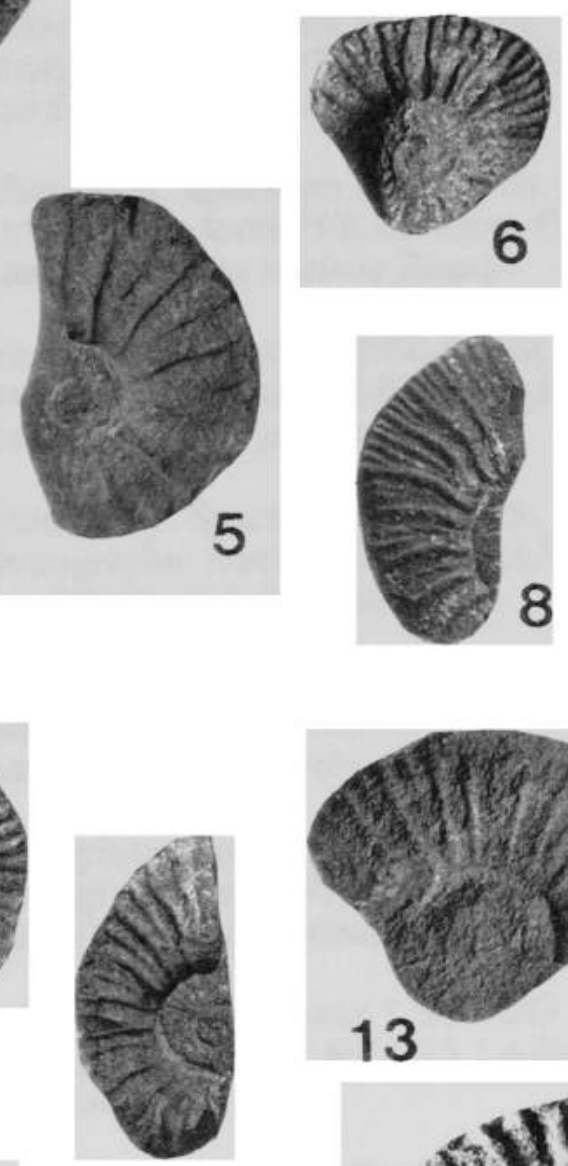

12
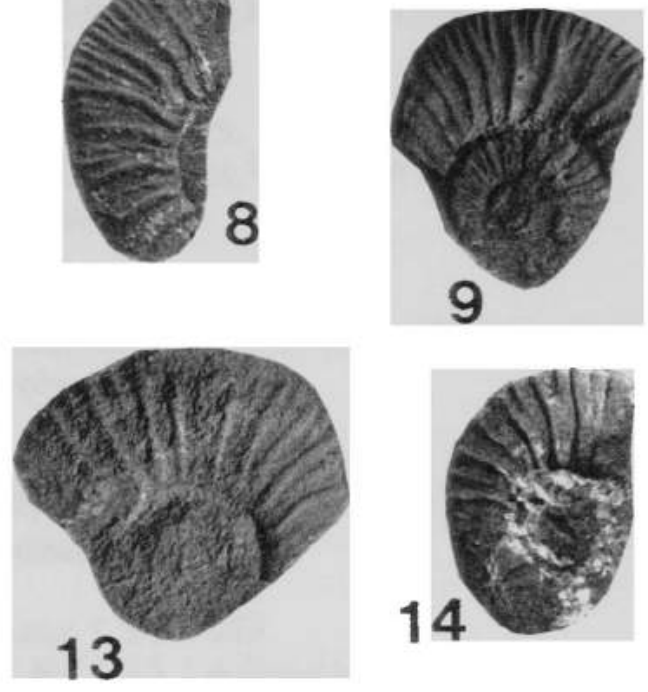

16

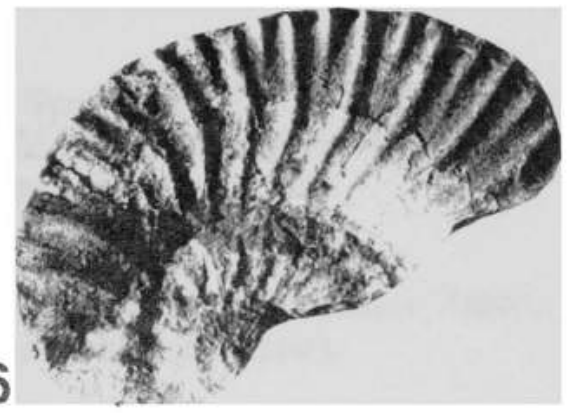




\section{PLATE 57}

Figure 1. Acanthohoplites potreritensis Humphrey. Specimen PFZ-0304.

La Peña Formation, stratigraphic level PFZ-110. Presa Francisco Zarco,

Durango. Middle Aptian

(Burckhardtites nazasen.sis/Rhytidoplites robertsi Zone).

Figure 2. Acanthohoplites potreritensis Humphrey. Specimen PFZ-0305a.

La Peña Formation, stratigraphic level PFZ-110. Presa Francisco Zarco,

Durango. Middle Aptian

(Burckhardtites nazasensis/Rhytidoplites robertsi Zone).

Figure 3. Colombiceras spathi Humphrey. Specimen PFZ 0346.

La Peña Formation, stratigraphic level PFZ-81. Presa Francisco Zarco, Durango. Lower Aptian (Dufrenoyia justinae Zone).

Figure 4. Colombiceras spathi Humphrey. Specimen PFZ-0210a, side view.

La Peña Formation, stratigraphic level PFZ-93. Presa Francisco Zarco, Durango. Lower Aptian (Dufrenoyia justinae Zone).

Figure 5. Colombiceras spathi Humphrey. Specimen PFZ-0210a, ventral view.

La Peña Formation, stratigraphic level PFZ-93. Presa Francisco Zarco, Durango. Lower Aptian (Dufrenoyia justinae Zone).

Figure 6. Colombiceras spathi Humphrey. Specimen PFZ $0210 \mathrm{~b}$.

La Peña Formation, stratigraphic level PFZ-93. Presa Francisco Zarco, Durango. Lower Aptian (Dufrenoyia justinae Zone).

Figure 7. Colombiceras spathi Humphrey. Specimen PFZ_0225.

La Peña Formation, stratigraphic level PFZ-93. Presa Francisco Zarco, Durango. Lower Aptian (Dufrenoyia justinae Zone).

Figure 8. Colombiceras spathi Humphrey. Specimen PFZ 0230.

La Peña Formation, stratigraphic level PFZ-93. Presa Francisco Zarco, Durango. Lower Aptian (Dufrenoyia justinae Zone).

Figure 9. Colombiceras spathi Humphrey. Specimen PFZ-0137b.

La Peña Formation, stratigraphic level PFZ-81. Presa Francisco Zarco, Durango. Lower Aptian (Dufrenoyia justinae Zone).

Figure 10. Colombiceras spathi Humphrey. Specimen LBC-0083.

La Peña Formation, stratigraphic level LBC 1-35. La Boca Canyon,

Nuevo Leon. Lower Aptian.

Figure 11. Hypacanthoplites cf. leanzae Humphrey. Specimen PFZ-0175.

La Peña Formation, stratigraphic level PFZ-140b. Presa Francisco Zarco, Durango. Upper Aptian (Hypacanthoplites cf. leanzae Zone).

Figure 12. Hypacanthoplites cf. leanzae Humphrey. Specimen PFZ-0180.

La Peña Formation, stratigraphic level PFZ-140b. Presa Francisco Zarco, Durango. Upper Aptian (Hypacantloplites cf. leanzae Zone). 
Figure 13. Hypacanthoplites cf. leanzae Humphrey. Specimen PFZ-0185.

La Peña Formation, stratigraphic level PFZ-140b. Presa Francisco Zarco, Durango. Upper Aptian (Hypacanthoplites cf. leanzae Zone).

Figure 14. Hypacanthoplites cf. leanzae Humphrey. Specimen PFZ-0190.

La Peña Formation, stratigraphic level PFZ-142a. Presa Francisco Zarco, Durango. Upper Aptian (Hypacanthoplites cf. leanzae Zone).

Figure 15. Hypacanthoplites cf. leanzae Humphrey. Specimen PFZ-0195.

La Peña Formation, stratigraphic level PFZ-173. Presa Francisco Zarco, Durango. Upper Aptian (Hypacanthoplites ct. leanzae Zone).

Figure 16. Hypacanthoplites cf. leanzae Humphrey. Specimen PFZ-0205.

La Peña Formation, stratigraphic level PFZ-173. Presa Francisco Zarco, Durango. Upper Aptian (Hypacanthoplites of. leanzae Zone). 
PLATE 57
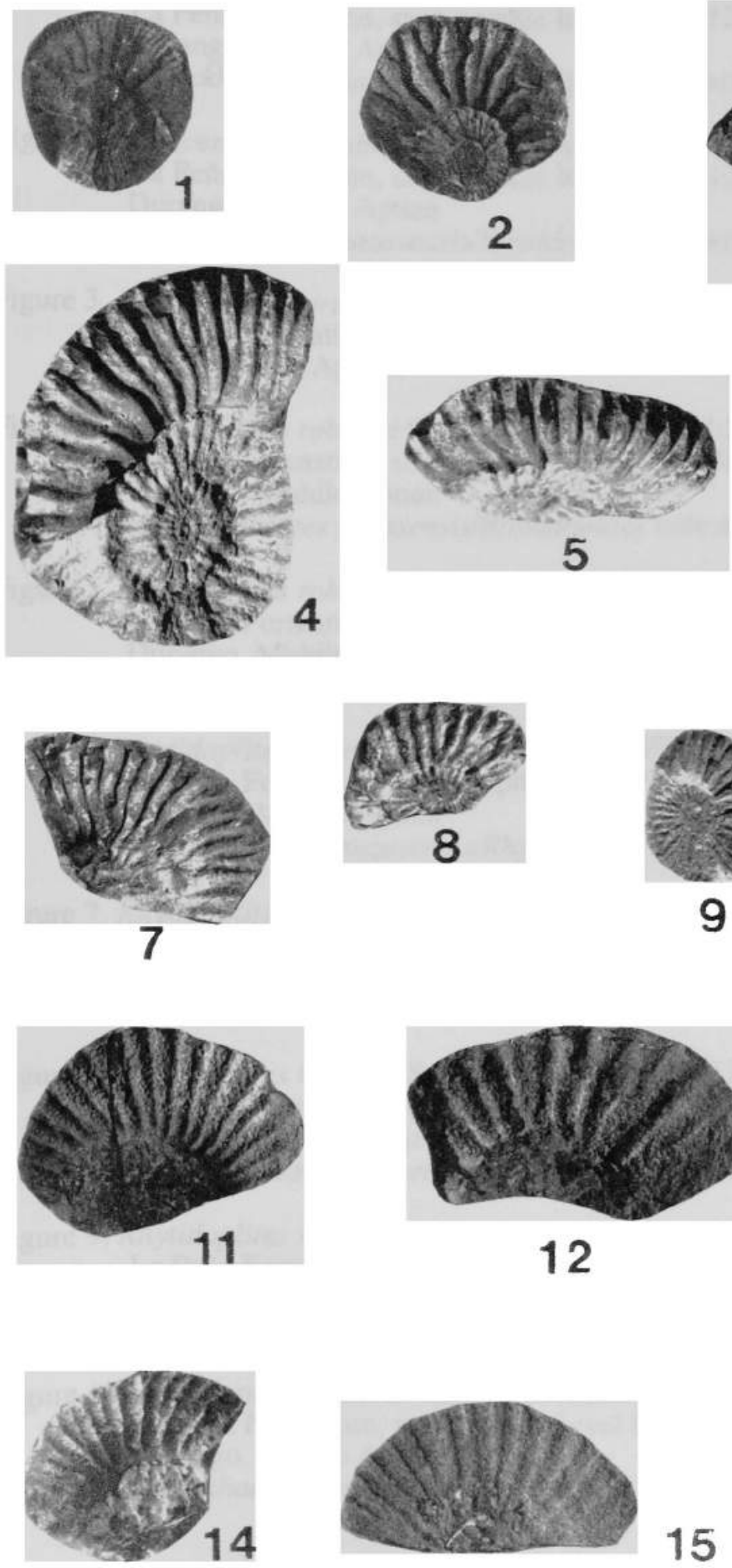
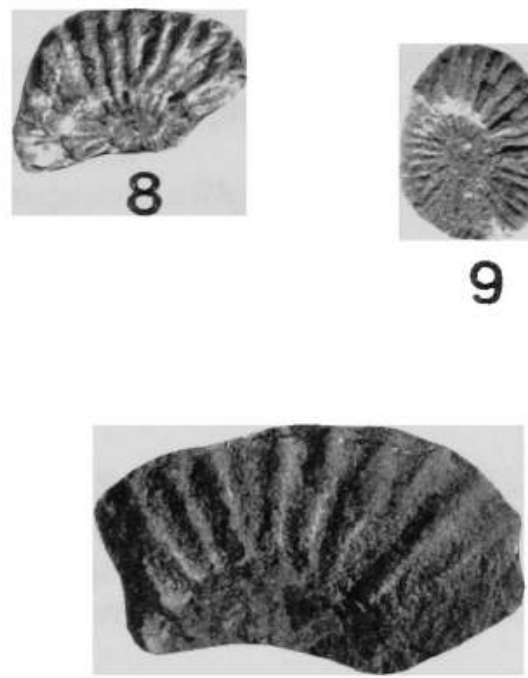

12
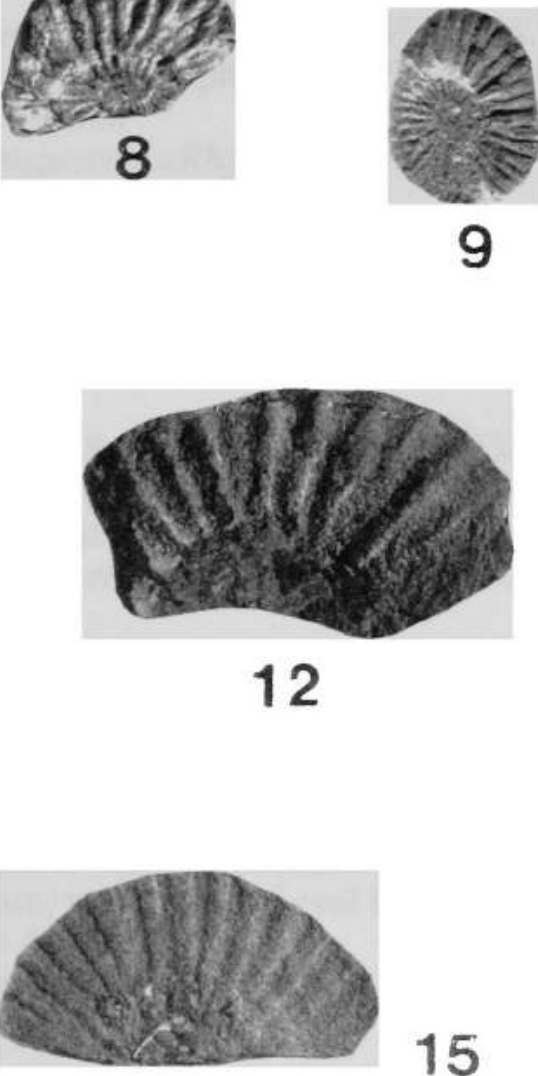
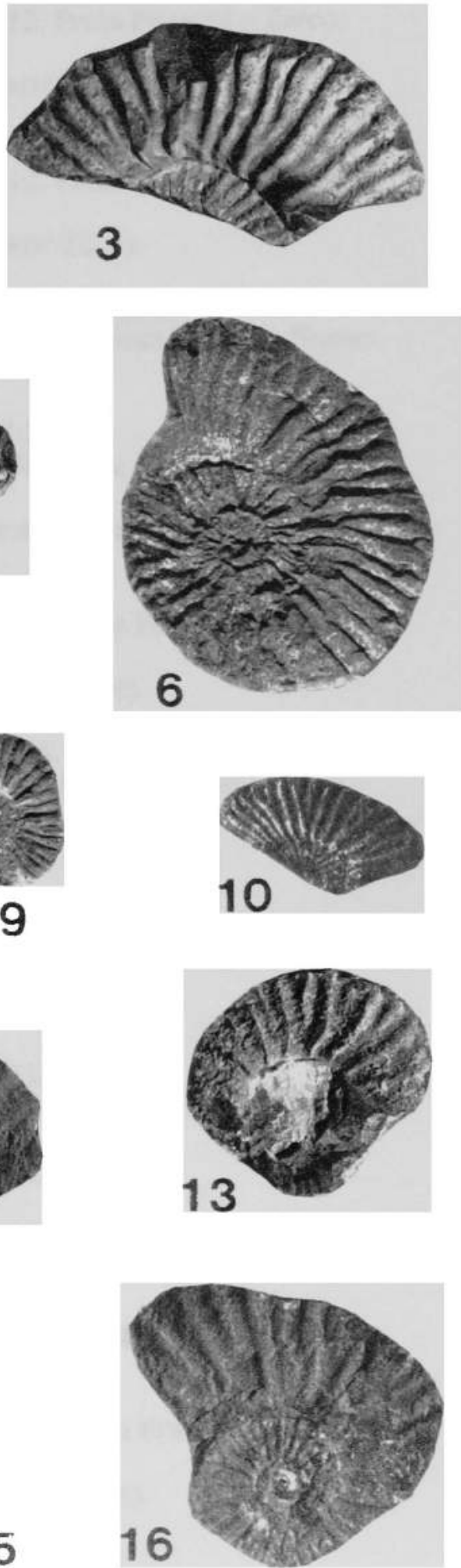


\section{PLATE 58}

Figure 1. Penaceras rursiradiatus (Humphrey). Specimen PFZ-0299.

La Peña Formation, stratigraphic level PFZ-112. Presa Francisco Zarco,

Durango. Middle Aptian

(Burckhardtites nazasensis/Rhytidoplites robertsi Zone).

Figure 2. Penaceras rursiradiatus (Humphrey). Specimen PFZ-0248.

La Peña Formation, stratigraphic level PFZ-112. Presa Francisco Zarco, Durango. Middle Aptian

(Burckhardtites nazasensis/Rhytidoplites robertsi Zone).

Figure 3. Penaceras rursiradiatus (Humphrey). Specimen LBC-0016.

La Peña Formation, stratigraphic level LBC D-4. La Boca Canyon, Nuevo

Leon. Middle Aptian.

Figure 4. Rhytidoplites robertsi Scott. Specimen PFZ-0148b.

La Peña Formation, stratigraphic level PFZ-108. Presa Francisco Zarco,

Durango. Middle Aptian

(Burckhardtites nazasensis/Rhytidoplites robertsi Zone).

Figure 5. Rhytidoplites robertsi Scott. Specimen PFZ-0153.

La Peña Formation, stratigraphic level PFZ-108. Presa Francisco Zarco,

Durango. Middle Aptian

(Burckhardtites nazasensis/Rhytidoplites robertsi Zone).

Figure 6. Rhytidoplites robertsi Scott. Specimen PFZ-0188.

La Peña Formation, stratigraphic level PFZ 110. Presa Francisco Zarco, Durango. Middle Aptian

(Burckhardtites nazasensis/Rhytidoplites robertsi Zone).

Figure 7. Rhytidoplites robertsi Scott. Specimen PFZ-0213.

La Peña Formation, stratigraphic level PFZ -110. Presa Francisco Zarco, Durango. Middle Aptian

(Burckhardtites nazasensis/Rhytidoplites robertsi Zone).

Figure 8. Rhytidoplites robertsi Scott. Specimen PFZ-0218.

La Peña Formation, stratigraphic level PFZ-110. Presa Francisco Zarco, Durango. Middle Aptian

(Burckhardtites nazasensis/Rhytidoplites robertsi Zone).

Figure 9. Rhytidoplites robertsi Scott. Specimen PFZ-0228.

La Peña Formation, stratigraphic level PFZ-112. Presa Francisco Zarco, Durango. Middle Aptian

(Burckhardtites nazasensis/Rhytidoplites robertsi Zone).

Figure 10. Rhytidoplites robertsi Scott. Specimen PFZ-0243.

La Peña Formation, stratigraphic level PFZ-1 12. Presa Francisco Zarco, Durango. Middle Aptian

(Burckhardtites nazasensis/Rhytidoplites robertsi Zone). 
Figure 11. Rhytidoplites robertsi Scott. Specimen LBC-0078a.

La Peña Formation, stratigraphic level LBC I-20. La Boca Canyon, Nuevo Leon. Middle Aptian.

Figure 12. Rhytidoplites robertsi Scott. Specimen LBC-0078b.

La Peña Formation, stratigraphic level LBC 1-20. La Boca Canyon, Nuevo Leon. Middle Aptian.

Figure 13. Rhytidoplites robertsi Scott. Specimen LBC-0138.

La Peña Formation, stratigraphic level LBC K-2. La Boca Canyon, Nuevo Leon. Middle Aptian.

Figure 14. cf. Kazanskyella arizonica Stoyanow. Specimen PFZ-0278.

La Peña Formation, stratigraphic level PFZ-112. Presa Francisco Zarco, Durango. Middle Aptian

(Burckhardtites nazasensis/Rhytidoplites robertsi Zone). 
PLATE 58
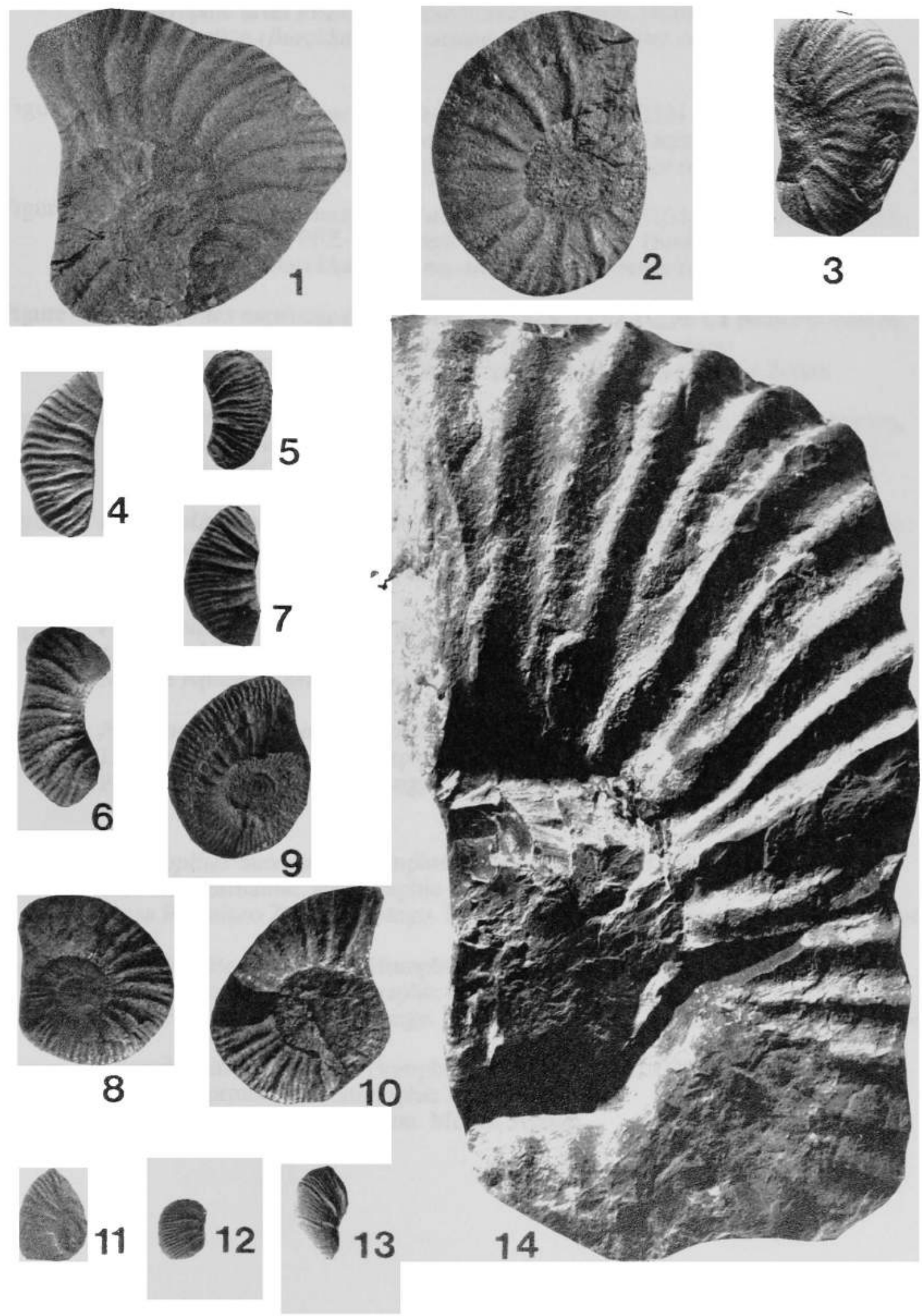


\section{PLATE 59}

Figure 1. Parahoplites mexicanus Humphrey. Specimen PFZ-0219. La Peña Formation, stratigraphic level PFZ-108. Presa Francisco Zarco, Durango.

Middle Aptian (Burckhardtites nazasensis/Rhytidoplites robertsi Zone).

Figure 2. Parahoplites mexicanus Humphrey. Specimen PFZ-0224. La Peña Formation, stratigraphic level PFZ-108. Presa Francisco Zarco, Durango.

Middle Aptian (Burckhardtites nazasensis/Rhytidoplites robertsi Zone).

Figure 3. Parahoplites mexicanus Humphrey. Specimen PFZ-0234. La Peña Formation, stratigraphic level PFZ-110. Presa Francisco Zarco, Durango.

Middle Aptian (Burckhardtites nazasensis/Rhytidoplites robertsi Zone).

Figure 4. Parahoplites mexicanus Humphrey. Specimen PFZ-0239. La Peña Formation, stratigraphic level PFZ 117. Presa Francisco Zarco, Durango.

Middle Aptian (Burckhardtites nazasensis/Rhytidoplites robertsi Zone).

Figure 5. Parahoplites mexicanus Humphrey. Specimen PFZ-0249. La Peña Formation, stratigraphic level PFZ-127c. Presa Francisco Zarco, Durango.

Upper Aptian (Cheloniceras inconstans Zone).

Figure 6. Parahoplites mexicanus Humphrey. Specimen PFZ-0254. La Peña Formation, stratigraphic level PFZ-129. Presa Francisco Zarco, Durango.

Middle Aptian (Cheloniceras inconstans Zone).

Figure 7. Parahoplites mexicanus Humphrey. Specimen PFZ-0259. La Peña Formation, stratigraphic level PFZ-129. Presa Francisco Zarco, Durango.

Middle Aptian (Cheloniceras inconstans Zone).

Figure 8. Parahoplites mexicanus Humphrey. Specimen PFZ-0264, side view.

La Peña Formation, stratigraphic level PFZ-129.

Presa Francisco Zarco, Durango, Middle Aptian (Cheloniceras inconstans Zone).

Figure 9. Parahoplites mexicanus Humphrey. Specimen PFZ-0264. ventral view.

La Peña Formation, stratigraphic level PFZ-129.

Presa Francisco Zarco, Durango. Middle Aptian (Cheloniceras inconstans Zone).

Figure 10. Parahoplites mexicanus Humphrey. Specimen PFZ-0274.

La Peña Formation, stratigraphic level PFZ-132.

Presa Francisco Zarco, Durango. Middle Aptian (Cheloniceras inconstans Zone).

Figure 11. Parahoplites mexicanus Humphrey. Specimen LBC-0080.

La Peña Formation, stratigraphic level LBC I-30.

La Boca Canyon, Nuevo Leon. Middle Aptian. 
PLATE 59

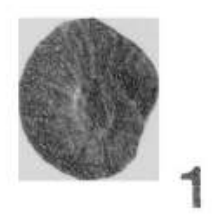

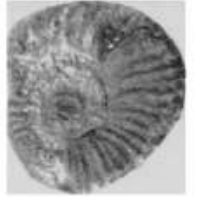

2

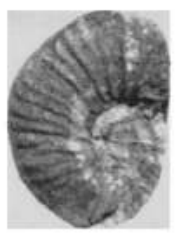

5

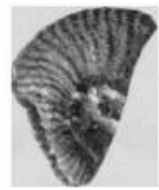

8
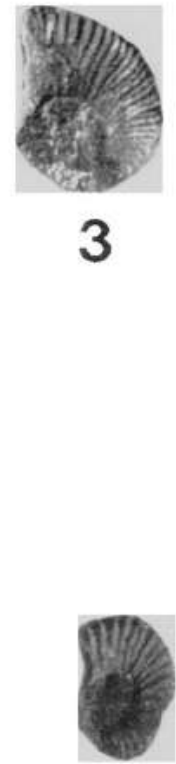

6

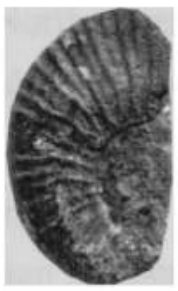

7
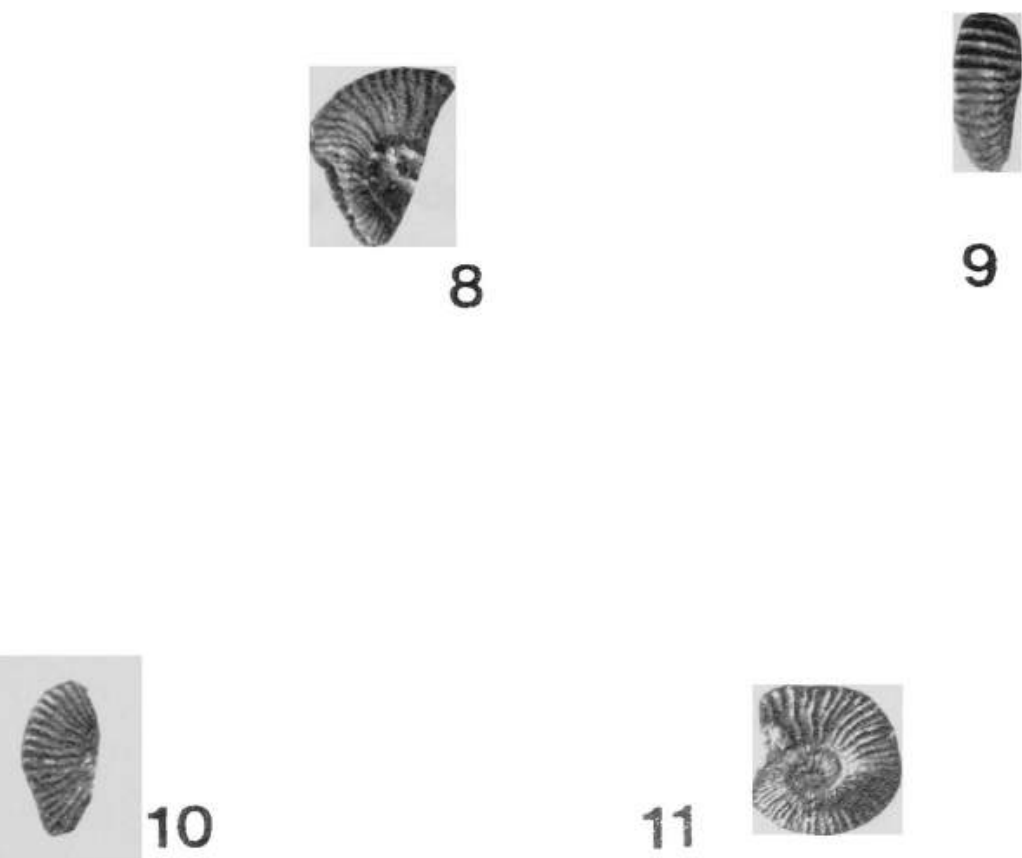


\section{VTTA}

\section{RICARDO BARRAGAN}

March 6, 1966

1993

$1999-2000$
Born, Tecomán, Colima, México

Licenciatura en Biología

National Autonomous University of Mexico

Mexico City, Mexico

Teaching Assistant

Florida Intemational University

Miami, Florida

\section{PUBLICATIONS AND PRESENTATIONS}

Barragan, R. (1997). Stratigraphic and sedimentological significance of the Aptian (Lower Cretaceous) transgressive event in northeast Mexico. $18^{\text {th }}$ Regional European Meeting of Sedimentology, IAS, Heidelberg, Germany, Abstracts vol. 3, p. 62.

Barragan, R. (1998). Stratigraphic Analysis of Barremian-Aptian Transgressive Sequences of Northeastern Mexico. 240 Coloquio Europeo de Micropaleontología, Bilbao, España, Resúmenes, p. 105.

Barragan, R. (1999). Sedimentary Facies and Organic Carbon Variations in BarremianAptian Sequences of Northeastem Mexico. Revista Española de Micropaleontología, 31(3), pp. 305-314.

Barragan, R., and Maurrasse, F. J. (1998). Facies changes in the Aptian of Northeastem Mexico, relationships to eustatic sea-level changes and mid-Cretaceous superplume activities. EOS, Transactions, American Geophysical Union 1998 Spring Meeting, v. 79 , No. 17, April 28 Supplement, p. S180. 

Presa Francisco Zarco
Stratigraphic Section
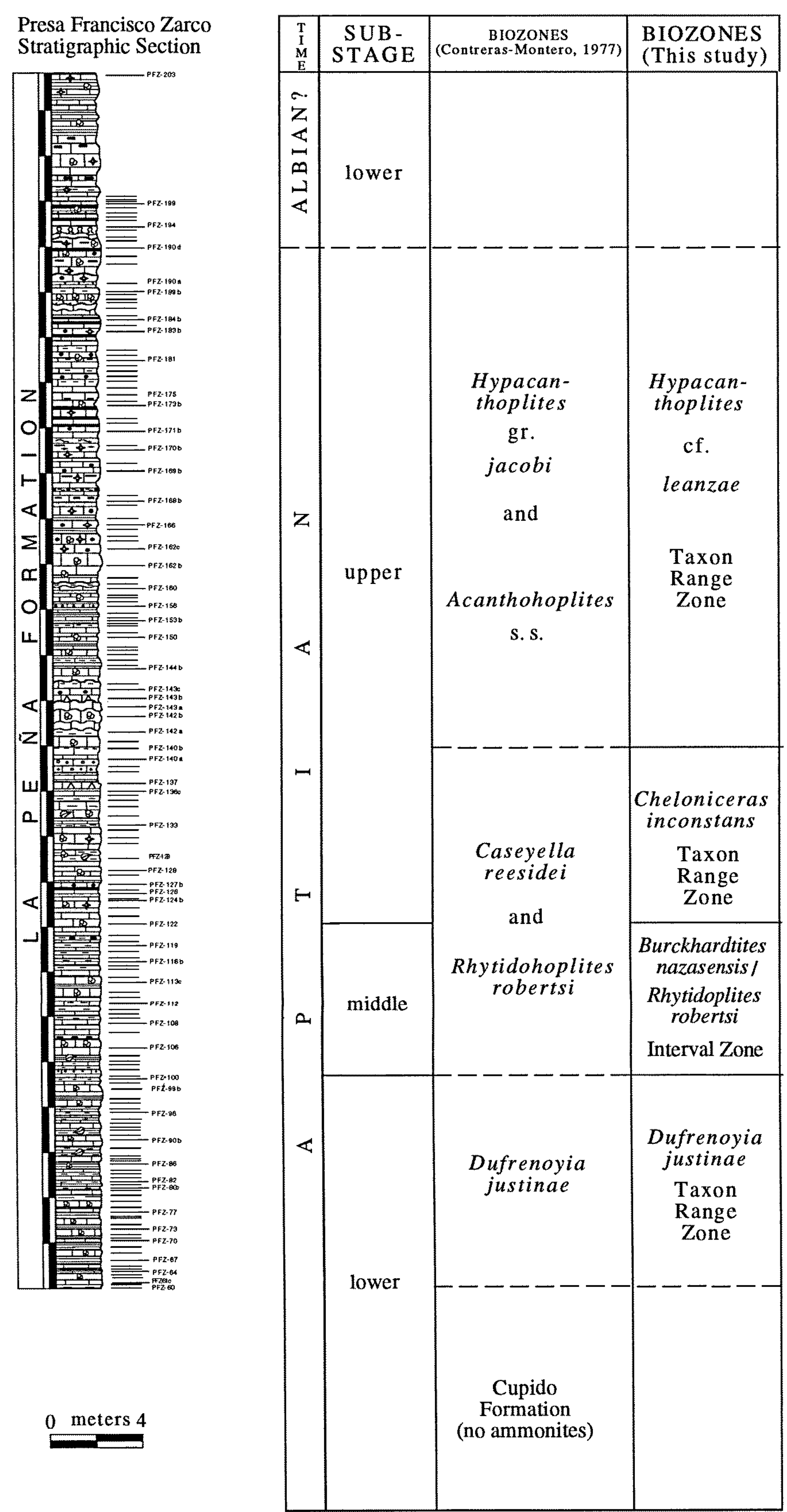

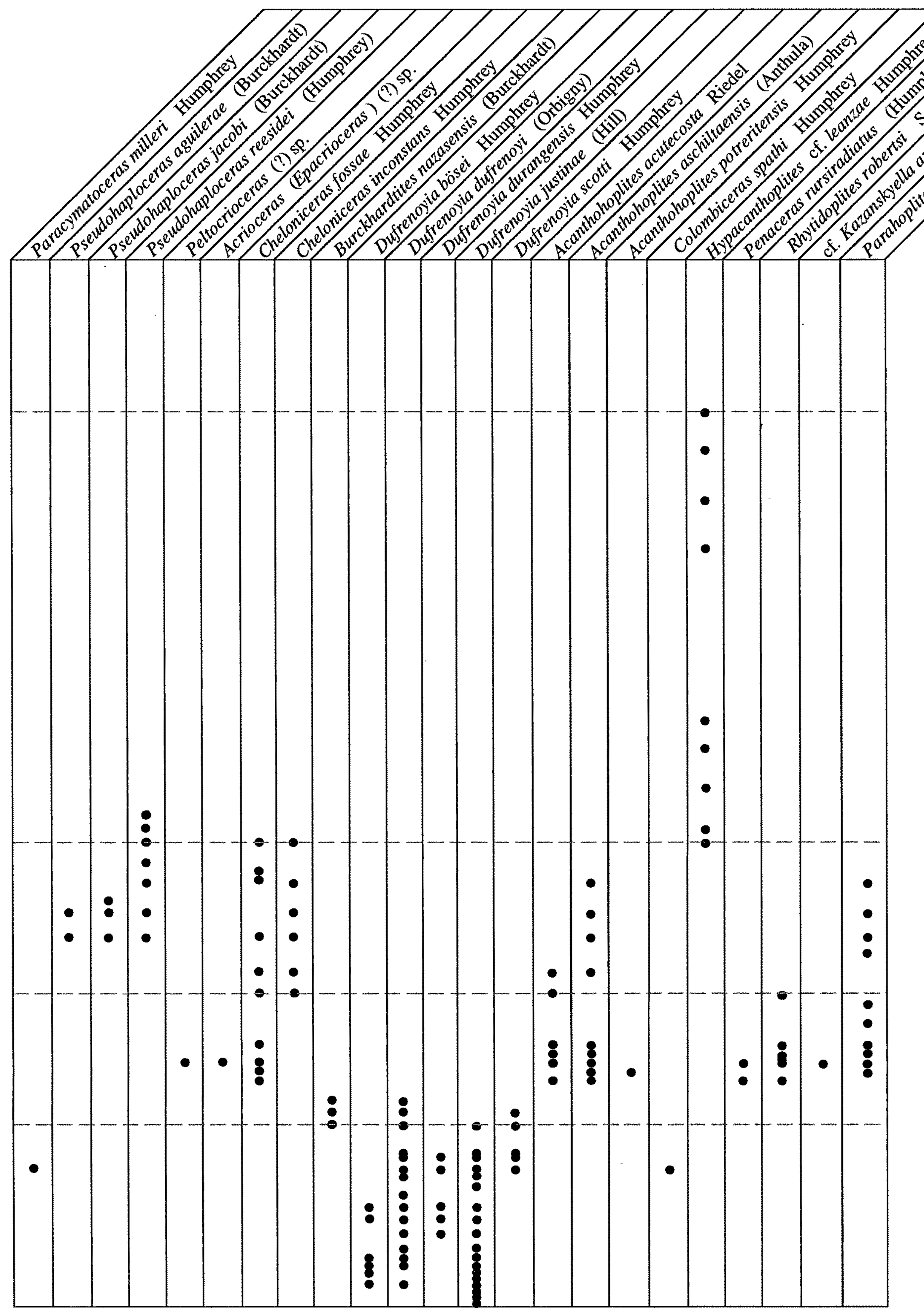

Figure 11. Stratigraphic distribution of ammonite species within the La Peña Formation at Francisco Zarco section and proposed ammonite biozonation for such formation. 
